\title{
Over de streep : grensarbeid vanuit Zuid-Limburg naar Duitsland, 1958-2001
}

Citation for published version (APA):

Bouwens, S. B. (2008). Over de streep : grensarbeid vanuit Zuid-Limburg naar Duitsland, 1958-2001. [Doctoral Thesis, Maastricht University]. Uitgeverij Verloren. https://doi.org/10.26481/dis.20081210sb

Document status and date:

Published: 01/01/2008

DOI:

10.26481/dis.20081210sb

Document Version:

Publisher's PDF, also known as Version of record

\section{Please check the document version of this publication:}

- A submitted manuscript is the version of the article upon submission and before peer-review. There can be important differences between the submitted version and the official published version of record.

People interested in the research are advised to contact the author for the final version of the publication, or visit the DOI to the publisher's website.

- The final author version and the galley proof are versions of the publication after peer review.

- The final published version features the final layout of the paper including the volume, issue and page numbers.

Link to publication

\footnotetext{
General rights rights.

- You may freely distribute the URL identifying the publication in the public portal. please follow below link for the End User Agreement:

www.umlib.nl/taverne-license

Take down policy

If you believe that this document breaches copyright please contact us at:

repository@maastrichtuniversity.nl

providing details and we will investigate your claim.
}

Copyright and moral rights for the publications made accessible in the public portal are retained by the authors and/or other copyright owners and it is a condition of accessing publications that users recognise and abide by the legal requirements associated with these

- Users may download and print one copy of any publication from the public portal for the purpose of private study or research.

- You may not further distribute the material or use it for any profit-making activity or commercial gain

If the publication is distributed under the terms of Article $25 \mathrm{fa}$ of the Dutch Copyright Act, indicated by the "Taverne" license above, 
Over de streep 
Maaslandse Monografieën, 71

Onder redactie van

Prof. Dr. P.J.A. Nissen (voorzitter)

Dr. W.J.M.J. Rutten (redactiesecretaris)

Prof. Dr. E. Aerts

Mevr. Dr. J.C. Dekker

Dr. M. van der Eycken

Prof. Dr. A.F.L. Gehlen

Dr. J.J. de Jong

Raad van Advies

L.J.P.M. Frissen (Maastricht)

S. Stevaert (Hasselt)

Prof. Dr. C. Bruneel (Louvain-la-Neuve)

Prof. Dr. A. Heinen (Aken)

Prof. Dr. P.M.M. Klep (Nijmegen)

Prof. Dr. A. Labrie (Maastricht)

Prof. Dr. J.M.W.G. Lucassen (Amsterdam)

Prof. Dr. G.W.J. Rooijakkers (Amsterdam)

Prof. Dr. H. Soly (Brussel)

Prof. Dr. R. van Uytven (Antwerpen)

De in deze serie verschenen delen staan vermeld op pag. 223

Stichting Maaslandse Monografieën

De Stichting Maaslandse Monografieën werd in 1964 in het leven geroepen door het Sociaal Historisch Centrum voor Limburg en Limburgs Geschied- en Oudheidkundig Genootschap en staat onder bestuur van:

Mr. W.F.E.R.M. van Oppen (voorzitter)

Prof. Dr. A. Knotter (secretaris)

Drs. H.J.L.M. Boersma MBA (penningmeester)

Prof. Dr. A.M.J.A. Berkvens

Dr. N.J.P.M. Bos

Mevr. Mr. C. de Koster

Dr. J.G.C. Venner 


\section{Over de streep}

\section{Grensarbeid vanuit Zuid-Limburg naar Duitsland, 1958-2001}

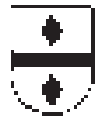

Hilversum 
Dit onderzoek kwam tot stand met steun van de Faculteit der Cultuur- en Maatschappijwetenschappen van de Universiteit Maastricht en het Duitsland Intstituut Amsterdam.

Op het omslag: Nederlandse grensarbeiders met hun auto voor een Duitse fabriek (c. 1970). Bron: SHCL: DOC 62, II, nr. 46. Foto: Frans Weehuizen in Televizier 1971, nr. 6.

$$
\text { ISBN 978-90-8704-078-9 }
$$

(C) Sophie Bouwens / Uitgeverij Verloren, Postbus 1741, 1200 Bs Hilversum

$$
\begin{aligned}
& \text { Omslagontwerp Het Lab, Arnhem } \\
& \text { Opmaak S-PrePress, Hilversum } \\
& \text { Druk Wilco, Amersfoort } \\
& \text { Bindwerk Van Waarden, Zaandam }
\end{aligned}
$$

No part of this book may be reproduced in any form without written permission from the author and publisher.

De uitgever heeft ernaar gestreefd de rechten van de illustraties volgens de wettelijke bepalingen te regelen. Degenen die desondanks menen rechten te kunnen doen gelden, kunnen zich alsnog tot de uitgever richten. 


\section{Voorwoord}

Een proefschrift schrijven is een traject waarin je grenzen verkent, leert kennen en verlegt. Dat doe je gelukkig niet alleen. Ik wil graag een aantal personen bedanken die het de moeite waard hebben gemaakt deze weg te bewandelen en mij in staat hebben gesteld de eindstreep te halen.

Op de eerste plaats mijn begeleiders. Mijn eerste promotor Ad Knotter wil ik bedanken voor zijn betrokkenheid, nauwkeurige commentaar, aanmoediging en de ruimte die hij me liet om mijn eigen weg te gaan. Ton Nijhuis, mijn tweede promotor, dank ik voor zijn vertrouwen en scherpzinnige kritiek die vaak op precies het juiste moment kwam.

Het verzamelen van gegevens kun je in veel gevallen niet alleen. Zonder de grensarbeiders die ik heb mogen interviewen was een groot deel van dit onderzoek onmogelijk geweest. Ik dank hen voor hun bereidheid hun verhaal met mij te delen. Ook de medewerkers van verschillende archieven, in het bijzonder die van het Sociaal-Historisch Centrum voor Limburg, wil ik bedanken voor hun behulpzaamheid bij het boven tafel krijgen van het benodigde materiaal. Een speciaal woord van dank aan Willibrord Rutten voor zijn ondersteuning bij het gereedmaken van de kopij voor de uitgever.

Behalve van inspirerende vragen en suggesties die ik van deelnemers aan onder meer de conferenties van de Association of Borderlands Studies, het Advanced Seminar van de European Graduate School for Training in Economic and social-historical Research en de European Social Science and History Conference kreeg, heb ik door de jaren heen veel opgestoken van commentaren van Martin van der Velde, Andries de Grip, Anke Strüver en Alexandra Schwell.

Het schrijven van mijn dissertatie werd bijzonder veraangenaamd door de prettige werksfeer op de Faculteit der Cultuur- en Maatschappijwetenschappen. Met name de leden van de capaciteitsgroep Geschiedenis en de deelnemers aan de onderzoeksgroep PCE bedankt voor de prikkelende vragen, mooie voordrachten en de borrels in De Poort. In het begin van mijn onderzoekstraject heb ik veel gehad aan de 'whiskey-club' van Arnold Labrie. Uitwisseling met 'lotgenoten' bleek ook bijzonder prettig tijdens de aio-soep. Alle deelnemers daaraan bedankt voor jullie betrokkenheid, gezelligheid en 'food for thought'. Jullie hebben me eens te meer duidelijk gemaakt hoe verrijkend het is om zowel disciplinaire als landsgrenzen te overschrijden. Dat laatste geldt zeker voor Babette, met wie ik het langst mijn werkkamer heb gedeeld, en die me dagelijks met mijn onderzoeksthema confronteerde. Ik heb genoten van je verhalen, de creatieve oplossingen waar je mee kwam als ik weer eens dreigde vast te lopen, je geweldige taalgevoel en niet te vergeten de chocola. Verder wil ik Mieneke, Maud, Susan, Vivian, Niki, Merel, Saskia en natuurlijk Patrick bijzonder bedanken voor alle lunches en andere vormen van afleiding. Patrick, ik ben blij je straks aan mijn zijde te hebben tijdens de verdediging.

Ook buiten de UM waren contacten met andere promovendi waardevol. De bijeenkomsten van het NW Posthumus-instituut en het Graduiertenkolleg van het Duitslandinstituut boden goede 
ontmoetingsplekken. Ik wil in het bijzonder Marloes Hulsken bedanken voor de goede gesprekken over onze onderzoeken en alles daar omheen.

Babette, Patrick, Emiel, Evelien, Saskia Bonjour en Saskia Stevens wil ik nog bedanken voor het commentaar dat zij in de eindfase op één of meerdere hoofdstukken leverden.

Mijn nieuwe collega's aan de Haagse Hogeschool dank ik voor het fijne eerste jaar en hun betrokkenheid bij mijn geworstel met de laatste loodjes. Dave van Ginhoven ben ik erkentelijk voor de correctie van de Engelstalige samenvatting.

Dan mijn vrienden die me tijdens etentjes, cafébezoekjes, films, concerten en wandelingen lieten zien dat er buiten het proefschrift nog zat te doen is. Tijd om de frequentie van deze activiteiten weer wat op te schroeven! Een speciaal woord van dank aan Saskia. We kennen elkaar al sinds onze kindertijd en hebben sindsdien lief en leed gedeeld: zowel op de atletiekbaan, als tijdens onze studie en nu als promovendi. Fijn dat ook jij straks aan mijn zijde staat. In de tussentijd geef ik het stokje graag aan je door voor jouw eindsprint.

Pap en mam, bedankt voor jullie onvoorwaardelijke steun en vertrouwen, en natuurlijk de heerlijke maaltjes die ik zeker gedurende de laatste fase op de terugweg vanuit Maastricht naar Tilburg geregeld bij jullie kreeg voorgeschoteld, waarbij ik dan ook nog eens flinke porties krachtvoer uit eigen tuin meekreeg. Emiel, jij was in letterlijke zin meestal ver weg, maar daarom niet minder betrokken. Toen je tijdelijk in Tilburg verbleef, kwam je me regelmatig achter mijn computer uit trekken voor een kop thee. Nu ik weer wat meer tijd heb, kom ik graag een keer bij jou op de thee, in welk oord dan ook. Astrid en Marcel, bedankt dat jullie zo veel oog zijn blijven houden voor mijn wel en wee en altijd in waren voor een potje Kolonisten of Risk, ondanks dat ik zo lang om 'de hete brij' heen bleef draaien. Gelukkig wordt de afstand Tilburg-Beek vanaf nu weer een stuk makkelijker te overbruggen.

Stephan, bedankt dat je er gewoon voor me bent en voor je grenzeloze begrip, relativering en enthousiasme. Hoewel de laatste fase van het promotietraject bijzonder hectisch was, wist $\mathrm{ik}$ al uit ervaring dat geen beer op de weg ons te veel is! Ik kijk ernaar uit om na dit drukke jaar weer wat meer ruimte te hebben om samen te genieten. 


\section{Inhoud}

\section{Voorwoord}

1 Werk in de marge? 11

Grensarbeid als randverschijnsel $\quad 11$

Grenzen centraal $\quad 14$

Het onderzoek 19

2 Over theoretische en methodologische kaders 23

$\begin{array}{ll}\text { Lijnen in de literatuur } & 23\end{array}$

Dimensies en dynamiek van grenzen $\quad 24$

$\begin{array}{ll}\text { Het perspectief van de 'periferie' } & 27\end{array}$

$\begin{array}{lr}\text { Grensarbeid(ers) als grensgeval(len) } & 29\end{array}$

Onderzoeksaanpak $\quad 34$

$\begin{array}{ll}\text { Beschrijvende statistiek } & 34\end{array}$

$\begin{array}{ll}\text { Krantenartikelen } & 35\end{array}$

Interviews 36

3 Zuid-Limburg: tussen en over grenzen 39

'Een eigenaardig kind in de Nederlandsche familie' 39

Van brikkenbakkers tot bouwvakkers $\quad 44$

4 Wat grensbewoners beweegt. De Duitslandpendel in regionaal sociaal- $\quad 48$

economisch perspectief

De ontwikkeling van de pendelstroom naar Duitsland $\quad 48$

Omvangrijke en fluctuerende pendel 50

Kwantitatieve divergentie $\quad 50$

Kwalitatieve aansluiting $\quad 55$

$\begin{array}{ll}\text { Binnenlandse pendel versus grensoverschrijdende pendel } & 61\end{array}$

$\begin{array}{ll}\text { Marginale en stabiele pendel } & 63\end{array}$

$\begin{array}{ll}\text { Kwantitatieve parallellen } & 63\end{array}$

$\begin{array}{ll}\text { Herstructurering } & 66\end{array}$

$\begin{array}{ll}\text { Binnenlandse pendel versus grensoverschrijdende pendel } & 72\end{array}$

$\begin{array}{ll}\text { Slot } & 74\end{array}$ 
5 Tussen wens en werkelijkheid. De herdefiniëring van 'het pendelprobleem'

in de regionale publieke sfeer

Een eerste indruk

Definitie vanuit een begrensd referentiekader

Ten koste van 'de Nederlandse gemeenschap'

'Een noodgebied'

'Een dagelijks probleem voor de pendelaars zelf'

'Een nationale zaak'

'Groeipijnen van de wordende Europese eenheid'

Definitie vanuit een ontgrenzend referentiekader

Van acceptatie naar verwelkoming

Pioniers en slachtoffers

$\begin{array}{ll}\text { Tussen euroretoriek en nationaal belang } & 107\end{array}$

Slot

6 Grenzen verleggen. Grensarbeiders over het werken in Duitsland

Over een drempel

Onderweg

'In den vreemde'

Professionele onzekerheid

Taalbarrière

Verwarring over wet- en regelgeving

Sociale onzekerheid

128

Toenadering en distantiëring

Professionalisering

Taalbeheersing

Grensoverschrijding en grensbewaking $\quad 136$

De pendel tot stilstand?

Slot

7 Over de streep

Grenswerk

Van paradox naar parallel

Van periferie tot centrum

Transformatie, confrontatie en continuatie

Eurovisie en regionale praktijk

Bijlagen

Appendix A - Bronnenkritiek statistiek 


\section{Geraadpleegde bronnen}

Persdocumentatie

$\begin{array}{lr}\text { Literatuur } & 175\end{array}$

Internet $\quad 183$

Correspondentie $\quad 184$

Fotocollecties $\quad 184$

$\begin{array}{lr}\text { Summary } & 185\end{array}$

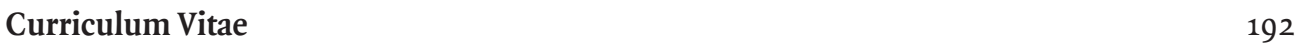

Figuren

1.1 De Euregio Maas-Rijn. 14

1.2 Kaart van Europa met de gebieden die subsidie hebben ontvangen in het kader 17 van het INTERREG IIIA-programma.

3.1 'Limburg' 1785-1794. 40

4.1 De omvang van de pendelstroom vanuit Zuid-Limburg naar Duitsland, 1960-2001 49

4.2 Grensarbeiders uit Zuid-Limburg in Duitsland naar bedrijfstak, 1963, 1968, $\quad 56$ 1973,1974

4.3 Grensarbeiders uit Zuid-Limburg in Duitsland naar geslacht, 1960-1979 57

4.4 Grensarbeiders uit Zuid-Limburg in Duitsland naar woongewest, 1963, 1968, 59 1973,1978

4.5 Grensarbeiders uit Zuid-Limburg naar Duitse werkrayons, 1970, 1973, $1978 \quad 60$

4.6 Grensarbeiders uit Nederland in de Regio Aken naar beroepsgroep, 1990, 1995, 67 2000

4.7 Grensarbeiders uit Zuid-Limburg in Duitsland naar geslacht, 1980-2001 69

4.8 Grensarbeiders uit Zuid-Limburg in Duitsland naar woongewest, 1983, 1987, 199171

4.9 Grensarbeiders uit Zuid-Limburg naar Duitse werkrayons, 1983, 1988, $\quad 72$ $1993,1998$.

4.10 Verschillen en overeenkomsten in vraag en aanbod tussen de arbeidsmarkten $\quad 74$ in Zuid-Limburg en het aangrenzende Duitse gebied per periode

5.1. Aantal gevonden artikelen over Duitslandpendel naar periode, 1957-2001 $\quad 78$

5.2 Verdeling artikelen naar evaluatie van de pendel naar Duitsland, 1957-2001 79

\section{Tabellen}

1.1 Belangrijke Europese overeenkomsten en maatregelen voor grensarbeiders, 1957-2001 12

4.1 Grensarbeiders uit Nederland in Duitsland naar leeftijd en geslacht, 1963, 1967, 58 1971, 1975, 1979

4.2 Aandeel binnenlandse en Duitslandpendelaars woonachtig in Zuid-Limburg 61 naar woongewest, 1963, 1968, 1973, 1977 (\% van de beroepsbevolking)

4.3 Grensarbeiders uit Nederland in Duitsland naar leeftijd en geslacht, 1983, 1988, 70 1993,1998

4.4 Aandeel binnenlandse en Duitslandpendelaars woonachtig in Zuid-Limburg naar 73 woongewest, 1981, 1985, 1991 (\% van de beroepsbevolking).

5.1 Partijen naar frequentie van hun aanwezigheid in berichtgeving per periode $\quad 80$ 


\section{Hoofdstuk 1 \\ Werk in de marge?}

\section{GRENSARBEID ALS RANDVERSCHIJNSEL}

Al vanaf het begin staat het naoorlogse Europese integratieproces onder meer in het teken van het opheffen van de belemmerende werking van staatsgrenzen op grensoverschrijdende interactie. Grensoverschrijdende arbeidsmobiliteit wordt cruciaal geacht voor de totstandkoming van 'het ene Europa'. Het vrij verkeer van personen geldt als een van de grondbeginselen in de samenwerking. Samen met het vrij verkeer van goederen, diensten en kapitaal vormt het de zogenaamde 'vier vrijheden' die reeds in het Verdrag van Rome (1957) werden genoemd als kenmerken van de beoogde gemeenschappelijke markt. Werken over grenzen zou bijdragen aan een optimale allocatie van de productiefactor arbeid en aan de verbetering van de leef- en werkomstandigheden van individuele burgers. ${ }^{1}$ Het geldt bovendien als integratie 'van onderop', omdat het Europeanen in alledaagse situaties met elkaar in contact brengt. ${ }^{2}$ In de jaren 1990 nam het integratieproces een grote vlucht met het verdrag van Maastricht (begin 1992) en de realisering van de Europese eenheidsmarkt (eind 1992). Sindsdien wordt ook wel gesproken van een 'Europa zonder grenzen'. De implementatie van het akkoord van Schengen in 1995 (en later de opname daarvan in het Europese acquis communautaire) maakte het 'grenzeloze Europa' compleet. ${ }^{3}$

De afgelopen vijftig jaar zijn er allerlei maatregelen genomen om het werken over Europese binnengrenzen te faciliteren en te stimuleren (zie tabel 1.1). Europese autoriteiten zetten hoofdzakelijk in op het wegnemen van fysieke en institutionele barrières en het voorzien in informatie over grensoverschrijdend werken. Deze benadering blijkt evenwel weinig vruchten af te werpen. Alle maatregelen en aanmoediging ten spijt was de grensoverschrijdende

1 In het Verdrag van Parijs uit 1951, waarmee de Europese Gemeenschap voor Kolen en Staal werd opgericht, spraken Frankrijk, Duitsland, de Benelux-landen in Italië in artikel 69 ook reeds af te streven naar een vrij verkeer van geschoolde arbeidskrachten in de kolen-, ijzer- en staalindustrie. In eerste instantie werd er binnen de EEG ook vooral ingezet op het vrij verkeer van werknemers. Met de totstandkoming van de Eenheidsmarkt werd dit uitgebreid naar een vrij verkeer van personen (voor meer over de totstandkoming van het vrij verkeer van werknemers in de EGKS en de EEG en haar opvolgers, zie O'Keeffe, 'Freedom of movement for workers', 1920; zie ook Goedings, Labor Migration in an Integrating Europe); zie ook het interview met Europees Commissaris Špidla van Sociale Zaken en Gelijke Kansen over het jaar van de mobiliteit van werknemers op http://ec.europa.eu/employment_social/workersmobility_ 2006/indexcfm?id_page $=1$.

2 Zie het motto van het onderzoeksproject Pioneur gericht op de interne mobiliteit en de ontwikkeling van een Europese identiteit onder burgers van de lidstaten en andere landen in de EU (zie http://www.obets.ua.es/pioneur).

3 Dinan, Europe Recast; vgl. Strüver, 'Significant insignificance'. Het betreft hier uiteraard alleen de Europese binnengrenzen. De buitengrens is parallel aan het openen van de interne grenzen juist steeds verder afgesloten (zie Bort, 'European Borders in Transition'). 
TABEL 1.1 BELANGRIJKE EUROPESE OVEREENKOMSTEN EN MAATREGELEN VOOR GRENSARBEIDERS IN HET KADER VAN HET STREVEN NAAR HET VRIJ VERKEER VAN WERKNEMERS EN PERSONEN, 1957-2001.4

Jaar Overeenkomst/maatregel Inhoud m.b.t. grensarbeid

1957 Verdrag van Rome

1968 Verordening $1612 / 68$

1971 Verordening $1408 / 71$

1985 Schengenakkoord

1986 Europese Akte

1990 Schengenovereenkomst

1994 Oprichting Eures-netwerk

1995

Schengen

1997
Aankondiging maatregelen t.b.v. het garanderen van het vrij verkeer van werknemers (te realiseren binnen een termijn van 12 jaar ) (in werking in 1958) ${ }^{5}$

Recht op vrij verkeer van werknemers vastgelegd voor 'Europese' werknemers en hun gezinsleden (te realiseren uiterlijk 31-12-1969)

Coördinatie toepassing sociale zekerheidswetgeving bij grensoverschrijdende mobiliteit van werknemers en hun gezinsleden (in werking in 1972) ${ }^{6}$

Akkoord over geleidelijke afschaffing grenscontroles op personen aan de grenzen tussen de Benelux-landen, WestDuitsland, Frankrijk

Aankondiging maatregelen t.b.v. het realiseren van een Europese eenheidsmarkt, waaronder het zo veel mogelijk afschaffen van grenscontroles en andere grensgebonden belemmeringen (te realiseren uiterlijk 31-12-1992) (in werking in 1987)

Uitwerking Schengenakkoord

Oprichting netwerk t.b.v. grensoverschrijdende uitwisseling van vacatures en bemiddeling en informatievoorziening m.b.t. grensoverschrijdend werken binnen de Europese Economische Ruimte (EER) ${ }^{7}$

Implementatie Schengenovereenkomst ${ }^{8}$

Integratie Schengenacquis in EU-recht (in werking in 1999)

4 Op basis van Schmidt en Salt, 'The Development of Free Movement', zoals geciteerd in Recchi et al., Intra-EU Migration, 42; aangevuld op basis van O'Keeffe, 'Freedom of movement for workers', 20-24; Anderson en Bort, The Frontiers of the European Union 3-5. Verordening 1612/68 was de eerste maatregel met betrekking tot het vrij verkeer van werknemers die ook voor grensarbeiders gold. Verordening 15 uit 1961, die gericht was op het verwezenlijken van het vrij verkeer van werknemers, gold alleen voor grenspendelaars die op minimaal vijftig kilometer afstand van de grens werkten en maximaal eens per twee weken naar huis terugkeerden (Verschueren, 'Arbeidsrechtelijk statuut van de grensarbeider', 49-50). Door de jaren heen zijn er verder diverse maatregelen genomen om de erkenning van diploma's te regelen (http://europa.eu.int/scadplus/printversion/en/cha/coooo3d.htm). Ook bestaan er bilaterale afspraken over belastingheffing (bijv. het belastingverdrag tussen Nederland en Duitsland uit 1959 waarin werd afgesproken de inkomstenbelasting in het werkland te heffen), zie Van Leijenhorst, Wonen en werken aan weerszijden van de Nederlandse grens, 47-53.

5 Destijds artikel 48 en 49 , nu artikel 39.

6 Verordening 1408/71 verving de eerdere coördinatieverordeningen $3 / 58$ en 4/58, en de specifiek op grensarbeiders gerichte Verordening $36 / 63$ (zie Van der Steen, 'De Europese coördinatieverordeningen', 83).

7 Eures staat voor European Employment Services en vervangt het SEDOC-systeem dat naar aanleiding van Verordening 1602/68 in 1972 was ingevoerd.

8 Spanje, Portugal Griekenland en Italië hebben zich in 1992 ook aangesloten (Zie Dinan, Europe Recast, 22o). 
arbeidsmobiliteit in de Europese Unie rond de laatste eeuwwisseling minimaal. ${ }^{9} \mathrm{Al}$ sinds het midden van de jaren 1970 woont en werkt slechts zo'n 1,5 procent van de Europeanen in een ander land dan het land van herkomst. ${ }^{10}$ Ook de grenspendel, het verschijnsel dat personen op het grondgebied van het ene land wonen en in loondienst op het grondgebied van een ander land werken en daarbij wekelijks dan wel dagelijks naar huis terugkeren, ${ }^{11}$ is kwantitatief gezien een randverschijnsel. Rond de eeuwwisseling pendelde maar 1,5 procent van de beroepsbevolking van de Europese grensgebieden naar een andere Europese lidstaat. ${ }^{12}$ Op basis hiervan kan er niet worden gesproken van één Europese arbeidsmarkt waarin het vrij verkeer van werknemers optimaal is.

Hoezeer het werken over grenzen ook wordt gepropageerd en gefaciliteerd, de Europese arbeidsmarkt kenmerkt zich dus vooral door immobiliteit. Het is echter maar de vraag of het aantal grensforensen altijd en overal zo marginaal is geweest. In dit boek wordt de ontwikkeling van één specifieke pendelstroom over een langere termijn bestudeerd: de grenspendel vanuit Zuid-Limburg naar Duitsland vanaf de oprichting van de EEG in 1958 tot de invoering van de euro als betaalmiddel in 2002. ${ }^{13}$ Deze casus is om drie redenen interessant. Op de eerste plaats is Zuid-Limburg een grensgebied dat nog geen twee eeuwen deel uitmaakt van Nederland, aan twee landen grenst en bekend staat om het vele grensverkeer in het verleden. Zo werkten er aan het einde van de negentiende eeuw talloze Zuid-Limburgers in Duitsland. ${ }^{14}$ Ten tweede maakt Zuid-Limburg deel uit van de Euregio Maas-Rijn (EMR), een in 1976 opgericht samenwerkingsverband met de Duitse Regio Aken, en de Belgische provincies Limburg en Luik en de Duitstalige Gemeenschap (zie figuur 1.1). ${ }^{15}$ Streven van de EMR is om grensoverschrijdende mobiliteit en interactie te bevorderen en de nadelen van de nationaal gezien perifere ligging van de verschillende deelgebieden op te heffen. De EMR is een van de oudste Euregio's, die tegenwoordig als 'laboratoria van Europese integratie' worden beschouwd. Het is dus bij uitstek een plek waar Europa concreet gestalte zou moeten krijgen. ${ }^{16}$ Op de derde plaats is de grenspendel vanuit Zuid-Limburg naar Duitsland interessant vanwege de vooral vanuit Nederlands oogpunt beladen Nederlands-Duitse betrekkingen. Net als in andere buurlanden hebben Duitsland en de Duitsers in Nederland een overwegend negatief imago. ${ }^{17}$

9 De Gijsel et al., 'Concepts and issues', 7-8; Van der Velde en Van Houtum, 'The power of cross-border labour market immobility', 102-103. Tegenwoordig werken er wel veel inwoners van de nieuwe lidstaten in andere (vaak oudere) lidstaten (zie Pijpers, Between Fear of Masses and Freedom of Movement). Deze zijn hier buiten beschouwing gelaten.

10 Zie http://ec.europa.eu/employment_social/workersmobility_2006/index.cfm?id_page_category=FF.

11 Op basis van de definitie van het CBS, zie bijvoorbeeld Sociale Maandstatistiek 1998/02, 47. Afstand speelt hierbij geen rol en personen die voor werkgevers gevestigd in het woonland werken, zijn hier zo veel mogelijk buiten beschouwing gelaten. N.B. De term (grens)pendel(aars) wordt in deze studie uitsluitend gebruikt om te verwijzen naar grensarbeid(ers) (of grensforensen) en dus niet naar andere vormen van grensoverschrijdende mobiliteit. Indien het om binnenlandse pendel gaat, wordt dit expliciet vermeld.

12 Van Houtum en Van der Velde, 'The power of cross-border labour market immobility', 101-102.

13 Zuid-Limburg betreft het zuidelijke deel van de Nederlandse provincie Limburg dat deel uitmaakt van de Euregio Maas-Rijn (oftewel tot en met de gemeente Roermond) (voorafgaand aan de gemeentelijke herindeling van 2007). Verder betreft 'Duitsland' tot oktober 1990 uiteraard de Bondsrepubliek Duitsland of West-Duitsland. In verband met de leesbaarheid wordt in dit boek echter volstaan met 'Duitsland'.

14 Langeweg, 'Werken over de grens'.

15 De Belgische provincie Limburg sloot zich in 1981 aan, de provincie Luik in 1983 en de Duitstalige Gemeenschap in 1992 (Knippenberg, 'The Maas-Rhine Euroregion', 608-610). De Regio Aken is in 1981 opgericht door de Kreise Aken, Düren, Euskirchen en Heinsberg, en de Kreisfreie Stadt Aachen de Regio Aken om als Duitse partner de samenwerking in de EMR te coördineren (zie http://www.regioaachen.de/).

16 Knippenberg, 'The Maas-Rhine Euroregion', 611.

17 Lademacher, 'Der ungleiche Nachbar' (over de andere buurlanden: zie andere bijdragen in dezelfde bundel); Wielenga, Van vijand tot bondgenoot. 


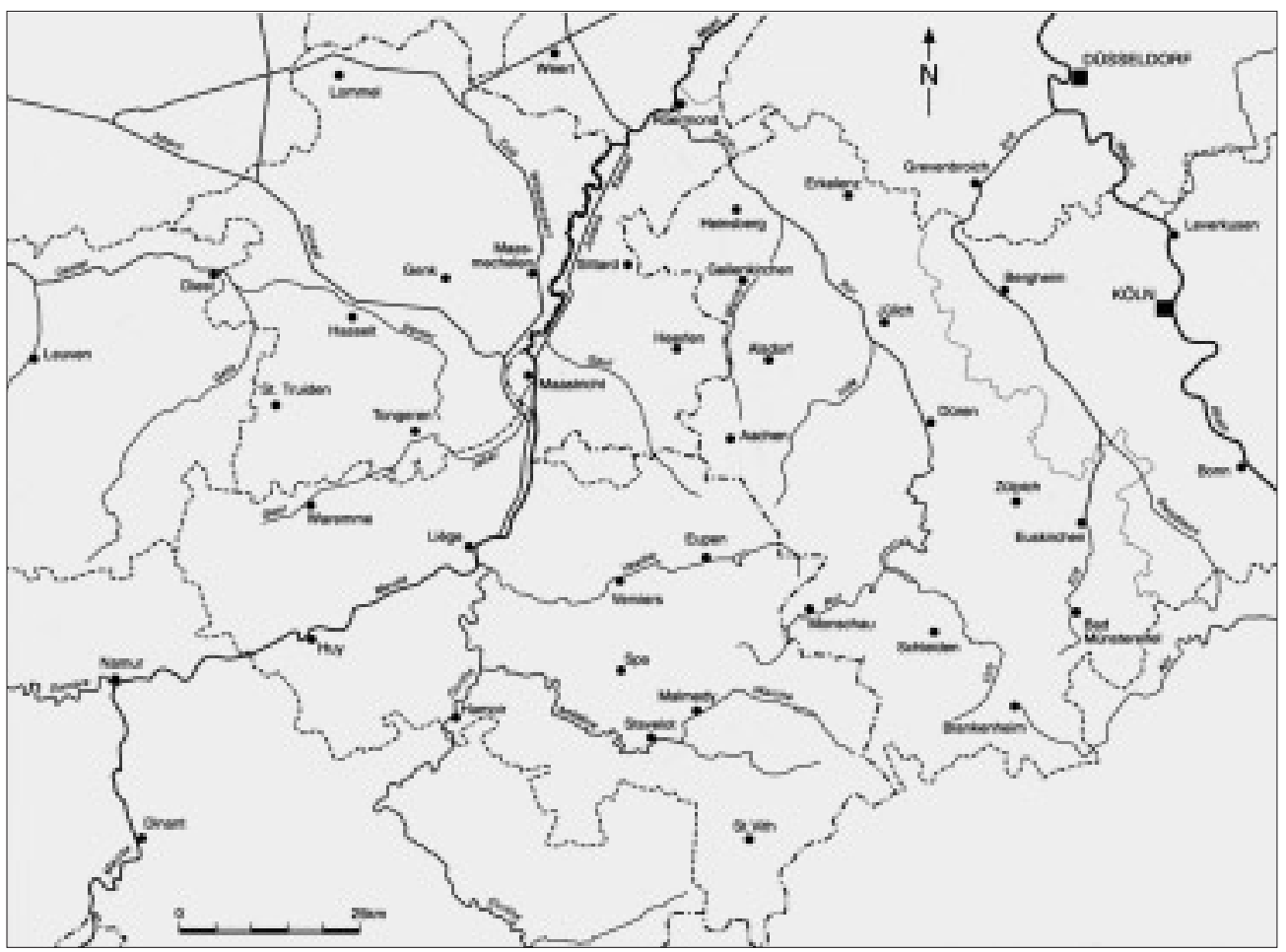

Bron: Marquart en Van Vugt, Blik over de grens.

Kern van deze studie vormt de vraag hoe grensarbeid vanuit Zuid-Limburg naar Duitsland zich tot de Nederlands-Duitse grens verhield in een periode waarin is getracht de barrièrewerking van deze grens te slechten. Daarbij wordt nagegaan hoe de grenspendel zich kwantitatief gezien heeft ontwikkeld, alsmede hoe hij in het grensgebied en onder de grensarbeiders zelf betekenis kreeg. Grensarbeid is onlosmakelijk verbonden met de grens. Ook om die reden is het een 'randverschijnsel'.

\section{GRENZEN CENTRAAL}

Op het eerste oog lijken staatsgrenzen eenduidige verschijnselen die dienen om het grondgebied van staten af te bakenen en hen in de gelegenheid te stellen dit te controleren. ${ }^{18}$ Hoewel grenzen duidelijke demarcaties vormen van territoria en politiek-bestuurlijke entiteiten, zijn het echter geen absolute afscheidingen. Er is altijd sprake van legaal dan wel illegaal grensverkeer, van goederen, geld, informatie en/of mensen. Grenzen zijn dus tegelijkertijd scheidslijnen en verbindingsstrepen tussen landen. Het spanningsveld tussen het begrensde en het grensoverschrijdende maakt grenzen en de aanpalende gebieden tot interessante onderzoeksobjecten. Grensforensen belichamen deze spanning omdat zij dagelijks dan wel 
wekelijks de grens over gaan om in het buurland te werken, maar ook telkens weer op hun schreden terugkeren. Daarnaast zijn grenzen erg veranderlijk. Zij kunnen decennia- of zelfs eeuwenlang vastliggen, maar hun open- en geslotenheid en de mate waarin zij worden overschreden, vertonen een grote diversiteit in de ruimte en de tijd. ${ }^{19} \mathrm{Zo}$ is de grens tussen Noorden Zuid-Korea al lange tijd vrijwel hermetisch afgesloten, en is de grens tussen Nederland en Duitsland tegenwoordig officieel nagenoeg volledig open, terwijl zij gedurende de Eerste Wereldoorlog was afgesloten.

Grenzen zijn dus continu in verandering. De spanning tussen hun hoedanigheid als scheids- en contactlijnen en de variabele wijze waarop daarmee wordt omgegaan, maakt hen tot buitengewoon boeiende fenomenen. Desondanks bevonden grenzen en grensgebieden zich lange tijd in de marges van de wetenschap. In de jaren 1990 is daar verandering in gekomen en zijn grenzen en grensgebieden steeds meer naar het centrum van de belangstelling verschoven. De toegenomen intellectuele interesse voor grenzen is het resultaat van een drietal onderling verbonden ontwikkelingen waarin de dynamiek van grenzen zich duidelijk manifesteert. Het betreft de versnelling van het globaliseringsproces, de beëindiging van de Koude Oorlog en de intensivering van de eerder beschreven Europese integratie. ${ }^{20}$

Allereerst heeft de versnelde mondialisering grenzen in de schijnwerpers geplaatst. Door de ontwikkeling van betere en goedkopere communicatie- en transportmiddelen zijn afstanden steeds makkelijker en sneller te overbruggen, waardoor de wereld kleiner en kleiner lijkt te worden. De socioloog Castells spreekt van een space offlows waarin goederen, informatie, kapitaal, bedrijven en burgers alsmaar mobieler worden en minder plaatsgebonden zijn. ${ }^{21}$ Door dit proces van deterritorialisering verliezen staten controle over informatie-, kapitaal-, goederen-, diensten- en mensenstromen en worden grenzen poreuzer. Er bestaat echter veel discussie over de vraag hoe deze processen zich precies tot staten en grenzen verhouden. Sommigen spreken van 'het einde van de natiestaat' en 'een grenzeloze wereld', ${ }^{22}$ maar lang niet iedereen is van mening dat de rol van natiestaten en hun grenzen is uitgespeeld. ${ }^{23}$ Zo zouden hun grenzen weliswaar een transformatie doormaken, maar zou dit geenszins betekenen dat zij hebben afgedaan. Hoewel staten macht afstaan aan hogere (en lagere) bestuursniveaus en steeds meer beleidsterreinen dereguleren, zou het hier vooral gaan om een aanpassing aan de veranderende omstandigheden waarmee zij hun voortbestaan veiligstellen. In het kielzog daarvan zouden grenzen veranderen, maar wel een zekere relevantie behouden. ${ }^{24}$ Anderen wijzen erop dat grenzen met name sinds de aanslagen van 11 september 2001 weer aan belang winnen. 'Westerse' landen trachten wereldwijde toegang tot informatie, goederen, kapitaal en diensten te krijgen, maar stellen tegelijkertijd steeds meer in het werk om ongewenste elementen buiten de deur te houden. ${ }^{25}$ Dat zien we in extreme mate aan de grens tussen de Vere-

\footnotetext{
19 Vgl. Anderson en O'Dowd, 'Borders, Border Regions and Territoriality', 594-596; Blake, 'Boundary permeability in perspective', $15-16$.

20 Newman en Paasi, 'Fences and neighbours'; Bucken-Knapp en Schack 'Borders Matter, but how?' 13-28; Anderson et al., 'Why Study Borders Now?', 8-11; Berg en Van Houtum 'Prologue', 1.

21 Zoals geciteerd door Paasi in 'The Changing Discourses on Political Boundaries', 25 (op basis van Castells, The Informational City). Castells onderscheidt daarnaast een 'space of places' waarin verzet tegen de 'space of flows' kan ontstaan.

22 Zie Ohmae, The Borderless World; Idem, The End of the Nation State.

23 Anderson en O'Dowd onderscheiden een sterke en een zwakke interpretatie van globalisering ('Borders, Border Regions and Territoriality', 599-600); Held en McGrew spreken van globalisten en sceptici ('The Great Globalization Debate', 3-49).

24 Zie bijv. Mann, 'Has Globalisation Ended the Rise and Rise of the Nation-State?'; Sassen, 'The State and the New Geography of Power'.

25 Nicol en Townsend-Gault, 'Introduction' 1-2; dit gebeurde echter al eerder, zie bijv. Cunningham 'Nations Rebound?'.
} 
nigde Staten en Mexico en tussen Israël en de Palestijnse gebieden, waar letterlijk dammen worden opgeworpen tegen respectievelijk illegale arbeidsmigranten en mogelijk terrorisme, maar ook in de Europese Unie waar onder meer het openen van de grenzen met de nieuwe lidstaten voor veel consternatie zorgt en de buitengrens steeds strenger wordt bewaakt.

Ten tweede heeft het einde van de Koude Oorlog het belang en de veranderlijkheid van grenzen nog eens onderstreept. Terwijl Europese grenzen in het verleden onderwerp waren van menig conflict en dikwijls verschoven, maakten zij tijdens de Koude Oorlog een periode van relatieve stabiliteit door. Aan het einde van de jaren 1980 kwam daar met de val van de Berlijnse Muur en de opening van het IJzeren Gordijn verandering in. De eerder vrijwel ondoordringbare grens tussen West- en Oost-Europa werd steeds verder geopend. Daarnaast viel een aantal voormalige Oostbloklanden uiteen in kleinere staten. Dat fragmentatieproces kreeg op uiteenlopende manieren zijn beslag. Zo ging de opdeling van Joegoslavië gepaard met een bloedige oorlog en werd Tsjecho-Slowakije na de 'Fluwelen Revolutie' op vreedzame wijze in tweeën gesplitst. Deze ontwikkelingen hebben het belang en de dynamiek van het bestaan, de locatie en het karakter van grenzen opnieuw onder de aandacht gebracht. ${ }^{26}$

Op de derde plaats heeft de intensivering van het Europese integratieproces de belangstelling voor grenzen en grensgebieden aangewakkerd. Na een periode van 'eurosclerose' zonder nieuwe verdragen ondertekenden de Europese lidstaten in 1986 de Europese Akte waarin maatregelen werden vastgelegd om op 31 december 1992 de Europese eenheidsmarkt tot stand te brengen. ${ }^{27}$ In de aanloop naar de 'grenzeloze' gemeenschappelijke markt kregen grensgebieden een nieuwe status. Terwijl zij voorheen veelal te boek stonden als perifere gebieden met een achterblijvende ontwikkeling, ging de Commissie hen in 'het Europa zonder grenzen' als regio's vol potentie beschouwen. Sindsdien gelden zij zoals gezegd als 'laboratoria van Europese integratie', de gebieden waar 'Europa' het meest pregnant gestalte moet krijgen. ${ }^{28}$ De Commissie verleent sinds 1990 subsidie aan Euregio's via de zogenaamde INTERREG-gelden. In de jaren daarna schoten de Euregio's als paddestoelen uit de grond. ${ }^{29}$ Inmiddels bestaat er een heel netwerk van Euregio's dat alle 'Europese' grenzen omspant (zie figuur 1.2). Met INTERREG-gelden worden (samen met nationale overheden) grensoverschrijdende projecten gefinancierd op bijvoorbeeld het gebied van verkeer en vervoer, onderwijs en arbeidsmarkt, culturele integratie, en recreatie en toerisme. Deze zouden een basis moeten leggen voor het ontstaan van geïntegreerde regio's aan de 'verdwenen' interne grenzen. ${ }^{30}$

\footnotetext{
26 Zie Anderson en Bort, The Frontiers of the European Union, 1-5; Anderson et al., 'Why Study Borders Now?', 8.

27 Dinan, Europe Recast, 205-231. Om slagvaardig te werk te kunnen gaan, werden bovendien institutionele hervormingen doorgevoerd die meer supranationale besluitvorming mogelijk maakten.

28 Scott, 'Euregions, Governance, and Transborder Cooperation', 106; de Europese Commissie sprak in 1990 zelf van 'de indicatoren voor het meten van de vooruitgang die bij de opbouw van Europa wordt geboekt' en van 'proeftuinen van de Europese integratie' (Commissie van de Europese Gemeenschappen, Mededeling van de Commissie inzake de levens- en arbeidsvoorwaarden, 15); zie verder ook de socioloog Strassoldo die 'grensgemeenschappen' als 'miniatuurtjes' van het nieuwe verenigde Europa beschouwt ('Border Studies', 392); de antropoloog Thomassen gebruikt de term 'mini-Europa' om het belang van grensgebieden voor antropologisch onderzoek te duiden ('Border studies in Europe', 38).

29 INTERREG maakt deel uit van het Europees Fonds voor Regionale Ontwikkeling (EFRO) waarmee de Commissie wil bijdragen aan een harmonieuze ontwikkeling in Europa.

30 Corvers, 'De visie op grensregio's', 19-20; zie ook O'Dowd en Wilson 'Frontiers of sovereignty', 12-13; Strüver, 'We are only allowed to re-act', 29 .
} 


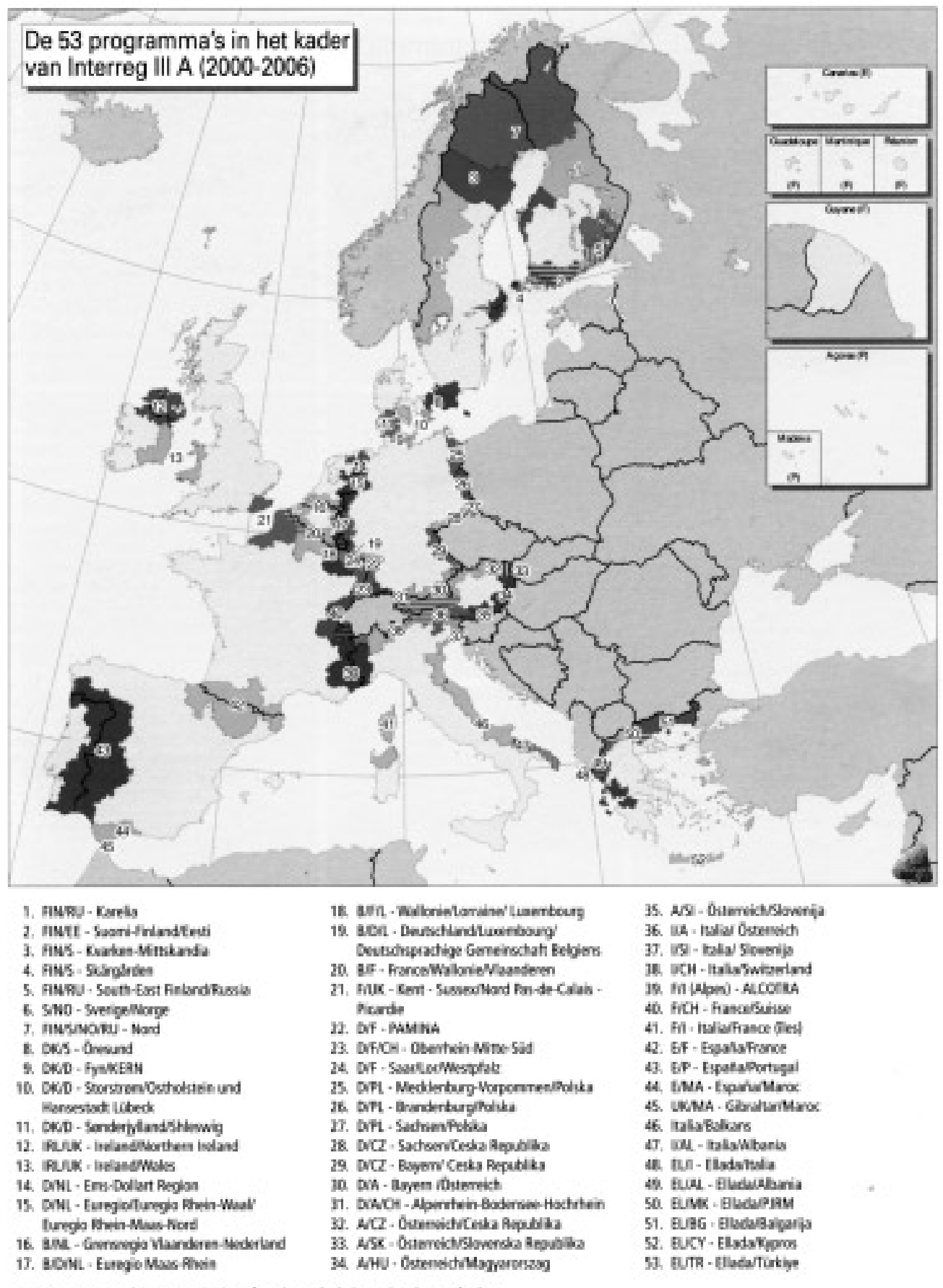

- EuroGtographics Assodiation for the administrative boundaries

Bron: Ergo et al, Samenwerking zonder grenzen, 9 . 
Ook in de context van het Europese integratieproces bestaan er meningsverschillen over de mate waarin natiestaten en hun grenzen aan betekenis hebben ingeboet. De historicus Milward spreekt in dit verband van 'the European rescue of the nation-state'. ${ }^{11}$ Anderen constateren dat Europese binnengrenzen ondanks de interne markt nog altijd verschillen markeren tussen bijvoorbeeld onderwijssystemen en belastingregimes en dat zij (mentale) belemmeringen voor economische en sociale interactie met zich meebrengen..$^{32}$ Bovendien zouden de Euregio's nog weinig succes boeken en grensbewoners onvoldoende weten te bereiken. ${ }^{33}$

Tegen deze achtergrond hebben grenzen en grensgebieden de gerichte aandacht gekregen die zij lange tijd moesten ontberen. Er is daarbij sprake van een paradox: terwijl grenzen onder invloed van het mondialiserings- en Europese integratieproces aan betekenis lijken in te boeten, genieten zij een groeiende belangstelling. ${ }^{34}$ Deze ontwikkelingen en de beëindiging van de Koude Oorlog hebben echter opnieuw duidelijk gemaakt dat grenzen niet zo maar kunnen worden uitgewist en een grote dynamiek kennen, waarbij er steeds een spanning bestaat tussen het nationale en het transnationale, in de vorm van grensoverschrijdende mobiliteit, interactie, oriëntatie en identificatie.

Tegenwoordig zijn grenzen en grensgebieden belangrijke onderzoeksobjecten voor geografen, antropologen, sociologen, economen, politieke wetenschappers en historici. In de loop der jaren heeft zich een multi- en in toenemende mate interdisciplinair onderzoeksveld heeft ontwikkeld, de zogenaamde grensstudies. ${ }^{35}$ De oprichting van verschillende onderzoeksinstituten die zich specifiek met de bestudering grenzen bezighouden, getuigt van de ontwikkeling die dit vakgebied gedurende de laatste twee decennia heeft doorgemaakt. ${ }^{36}$ Over de taak van de grensstudies zegt de geograaf Paasi: 'rather than mechanically repeating the arguments regarding the disappearance of states and boundaries, the challenge for border scholars is to develop new approaches for understanding their changing meanings' ${ }^{37}$ Vanwege de veranderlijkheid van grenzen pleit hij daarbij voor een historische benadering. ${ }^{8}$ Dat laatste heeft tot dusver nog relatief weinig navolging gekregen. ${ }^{39}$ Deze studie komt aan beide punten tegemoet door via de intensieve bestudering van de verhouding tussen de grenspendel vanuit Zuid-Limburg naar Duitsland en de Nederlands-Duitse grens zicht te bieden op de betekenis van een grens voor het dagelijks leven in een Europees grensgebied in de tweede helft van de twintigste eeuw.

31 Milward, The European Rescue of the Nation-State.

32 Bijv. Van Houtum, The Development of Cross-Border Economic Relations; Anderson en Bort, The Frontiers of the European Union, 7 , 10.

33 Zie Scott, 'Euroregions, Governance and Transborder Cooperation', 106, 113; over de Nederlands-Duitse Euregio Rijn-Waal, zie Strüver, 'We are only allowed to re-act', 33-35.

34 Anderson et al., 'Why Study Borders Now?'.

35 Zie bijv. de literatuuroverzichten in Newman en Paasi, 'Fences and neighbours'; Van Houtum, 'An Overview of Geographical Research'; Donnan en Wilson, Borders, 19-62; Staudt en Spener, 'The View from the Frontier'; Wendl en Rösler, 'Frontiers and Borderlands'; Cunningham en Heyman, 'Introduction'.

36 Zie ook Newman en Paasi, 'Fences and neighbours', 187 en Anderson et al., 'Why Study Borders Now?', 1. Voorbeelden zijn de International Border Research Unit (IBRU) aan de Universiteit van Durham, die in 1989 werd opgericht, en het Nijmegen Centre for Border Research (NCBR) aan de Radboud Universiteit in Nijmegen, dat in 1998 werd opgericht.

37 Paasi, 'Boundaries as social practice and discourse', 670.

$3^{8}$ Idem, 'The Changing Discourses on Political Boundaries', 19; zie ook Baud en Van Schendel, 'Toward a Comparative History', 212.

39 Uiteraard bestaat er wel historisch onderzoek naar grenzen, bijvoorbeeld de bekende studie van de historicus Sahlins over een deel van het Frans-Spaanse grensgebied (Boundaries), maar tot dusver betreft het meeste onderzoek binnen de grensstudies momentopnamen of kortetermijnstudies. 


\section{HET ONDERZOEK}

Grensarbeid wordt in dit onderzoek niet uitsluitend opgevat als een economisch fenomeen. Werk is meer dan een middel om in het levensonderhoud te voorzien. Het is tevens een manier om deel te nemen aan het maatschappelijk verkeer en op zinvolle wijze invulling te geven aan het dagelijks leven. Deze drieledige, economische, sociale en symbolische, betekenis van werk zien we terug in het belang dat er in Europees verband wordt gehecht aan grensoverschrijdende arbeidsmobiliteit. Die zou niet alleen bijdragen aan een uit economisch oogpunt optimale ruimtelijke spreiding van werknemers. Het vrij verkeer van personen wordt eveneens van groot symbolisch belang geacht voor 'het Europa van de burger'. Het brengt burgers in hun dagelijks leven met elkaar in contact, ${ }^{40}$ en zou op die manier ruimte kunnen bieden voor sociale en culturele integratie. ${ }^{41}$

Daarnaast wordt er in deze studie van uitgegaan dat een grens meer is dan een territoriale en politieke scheidslijn. ${ }^{42}$ Dat geldt zeker voor de Nederlands-Duitse grens, die een sterke symbolische lading heeft. Zoals gezegd zijn de relaties tussen Nederland en Duitsland vooral vanuit Nederlands oogpunt nogal beladen. De Tweede Wereldoorlog speelt daarbij een belangrijke rol, maar de negatieve beeldvorming kent een langere voorgeschiedenis. Volgens de historicus Wielenga ligt de essentie van de Nederlandse gevoeligheid tegenover Duitsland in de dubbelzinnige verhouding met dat land. Enerzijds vertonen Nederland en Duitsland cultureel gezien veel gelijkenissen. Anderzijds bestaan er grote verschillen in omvang en macht. In veel opzichten verkeert Nederland in een afhankelijke positie ten opzichte van Duitsland.

Cartoon over de verhouding NederlandDuitsland. Bron: Keim en Deppe, Hallo Nachbar!, 19 (cartoon van Frits Behrendt uit De Telegraaf, 1996).

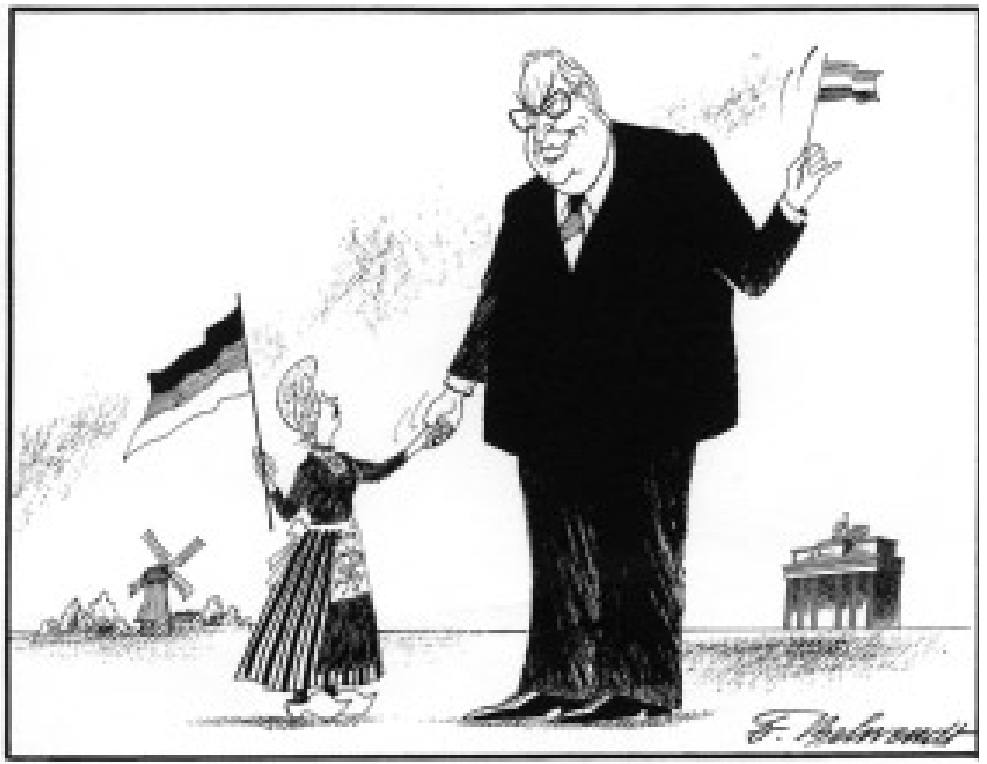

41 Zie bijv. De Gijsel et al., 'Concepts and issues in European cross-border labour economics', 10.

42 Zie bijv. Donnan en Wilson, Borders, 4-5. 
De talrijke overwegend negatieve stereotiepe beelden van Duitsers en Duitsland die in Nederland de ronde doen, dienen volgens Wielenga om de Nederlandse eigenheid en zelfstandigheid te articuleren. Dat geldt volgens hem evenzeer voor verwijzingen naar 'de' oorlog. Duitsers worden getypeerd als dominant, arrogant, militaristisch, bruut, gezagsgetrouw, hiërarchisch, prestatiegericht, punctueel, star en humorloos. Nederlanders zouden dan de positieve tegenpool van de Duitsers vertegenwoordigen. De Nederlandse identiteit is daarmee ten dele gestoeld op het onderscheid van de grote Duitse buur. Dat is andersom niet of nauwelijks het geval. De gevoeligheid van Nederlanders voor Duitsland en de Duitsers speelt op bepaalde momenten bijzonder op, zoals na de overwinning op het Duitse voetbalelftal tijdens de halve finale van de Europese Kampioenschappen van 1988 in Duitsland en na de brandstichting in een door Turken bewoond huis in Solingen in $1993 .{ }^{43} \mathrm{Er}$ bestaat geen eenduidig antwoord op de vraag hoe er in Nederlandse grensgebieden tegen Duitsers wordt aangekeken. Het beeld dat de grensbewoners van hen hebben, kan zowel positiever als negatiever uitvallen dan het algemene Nederlandse beeld. ${ }^{44}$ In Zuid-Limburg circuleerden er in de jaren 1990 niettemin allerlei 'Nederlandse' vooroordelen over de Duitsers, die deels werden verbonden met de Tweede Wereldoorlog. ${ }^{45}$

Om de complexiteit en dynamiek van grensarbeid en grenzen scherp in beeld te krijgen wordt de relatie tussen de grenspendel vanuit Zuid-Limburg naar Duitsland en de Nederlands-Duitse grens over een langere termijn en op drie manieren onderzocht: vanuit een regionale sociaal-economische invalshoek, vanuit een regionale sociaal-politieke invalshoek en vanuit het perspectief van de grensarbeiders. Vanuit regionaal sociaal-economisch oogpunt wordt de vraag beantwoord hoe de ontwikkeling van de omvang en samenstelling van de pendelstroom samenhing met arbeidsmarktomstandigheden aan weerszijden van de grens. Dat biedt zicht op de rol van de grens op de arbeidsmarkt en een context voor de rest van het boek waarin de betekenis van grensarbeid op regionaal en individueel niveau centraal staat. Teneinde via grensarbeid inzicht te verwerven in de betekenis van de grens voor Zuid-Limburg is het niet alleen relevant om te achterhalen hoeveel mensen er in Duitsland werkten en hoe dit samenhing met de regionale sociaal-economische ontwikkeling, maar ook hoe hier in de regionale context tegenaan werd gekeken. Daarom wordt Duitslandpendel tevens vanuit regionaal sociaal-politiek perspectief bestudeerd. Het gaat dan om de manier waarop verschillende sociale en politieke groeperingen de grenspendel in de regionale publieke sfeer evalueerden en hoe dit met de grens was verbonden. Het betreft met andere woorden de beeldvorming rond de Duitslandpendel in het regionale publieke domein. Deze werpt licht op de (gewenste) verhouding tussen het grensgebied en de natiestaat waarvan het deel uitmaakt. Tenslotte laten de ervaringen van de grensarbeiders zien hoe hun praktijken en percepties met betrekking tot het werken in Duitsland zich ontwikkelden en samenhingen met de grens. Om de relatie tussen grensarbeid en de grens vanuit deze drie standpunten te bekijken is gebruik gemakt van verschillende bronnen, respectievelijk geaggregeerd cijfermateriaal en eerder verschenen rapporten over grensarbeid, artikelen uit regionale kranten over grensarbeid en interviews met grensarbeiders. ${ }^{46}$

43 Wielenga, Van vijand tot bondgenoot, o.a. 347, 361, 378-384, 394. Zie ook Lademacher, 'Der ungleiche Nachbar'; Müller, 'Stille Tage im Klischee', 22-26; Linthout, Onbekende buren.

44 Zie Renckstorf en Lange, Niederländer über Deutsche, 35; Müller, 'Stille Tage im Klischee', 25; Wielenga, Van vijand tot bondgenoot, 312; Smit, 'Sociaal-culturele problemen', 114.

45 Van Beek, Samenwerking?, 85-89.

46 De manier waarop deze zijn gebruikt, wordt in hoofdstuk 2 en de appendices A, B en C nader beschreven. 
De inzichten zoals die in de verschillende onderdelen van deze studie ontstaan, vullen elkaar aan, bevestigen elkaar, maar wijken ook van elkaar af. Waar zitten de raakvlakken en scheidslijnen? En wat zegt dit over de grens in het leven van alledag in dit grensgebied? In het navolgende zal blijken dat de relatie tussen de grens en grensarbeid afhankelijk van het standpunt een ander karakter kan aannemen. Ook in die zin draait het hier dus om 'grenswerk'.

Dit boek bestaat uit zeven hoofdstukken. Aansluitend op deze inleiding wordt in hoofdstuk 2 een conceptueel kader geschetst om duidelijk te maken hoe grenzen, grensgebieden en grensarbeid in deze studie zijn benaderd. De literatuur uit het veld van de grensstudies geldt hierbij als vertrekpunt. Op basis daarvan worden grenzen beschouwd als dynamische en meerdimensionale verschijnselen die het dagelijks leven in grensgebieden vormgeven, maar daar zelf eveneens door worden beïnvloed. Uit de literatuur over grensarbeid blijkt dat er tot dusver veel onderzoek is verricht naar de totstandkoming en het uitblijven van grensarbeid. Minder aandacht was er voor de kwantitatieve ontwikkeling over een langere termijn en de manieren waarop het pendelen betekenis krijgt in het grensgebied en onder de grensarbeiders. Verder worden in hoofdstuk 2 de gehanteerde onderzoeksmethoden beschreven.

Hoofdstuk 3 biedt een nadere kennismaking met de casus. Eerst wordt daartoe de geschiedenis van het grensgebied Zuid-Limburg beschreven. Daarbij gaat de aandacht uit naar zijn moeizame integratie in de Nederlandse eenheidsstaat en zijn verhouding met Duitsland. Vervolgens wordt uitgebreid stilgestaan bij eerder onderzoek naar grensarbeid vanuit Zuid-Limburg naar Duitsland. Er bestaan verschillende momentopnames en kortere termijnstudies van de Duitslandpendel, maar in de naoorlogse periode heeft nog geen diepgaand onderzoek over een langere termijn plaatsgevonden. Daarnaast zal duidelijk worden dat er in dit grensgebied tot dusver evenmin oog was voor de betekenis die de grenspendel kreeg op regionaal en individueel niveau.

Het empirisch deel van deze studie bestaat uit drie hoofdstukken. In hoofdstuk 4 wordt de vraag beantwoord hoe de ontwikkeling van de omvang en samenstelling van de pendelstroom met de grens was verbonden. Om dit te achterhalen wordt ingezoomd op zijn inbedding in de sociaal-economische context en wordt zijn omvang vergeleken met die van de binnenlandse pendelstromen. Daaruit zal blijken dat de grootte en de structuur van de pendelstroom sterk wijzigden en dat er onder bepaalde omstandigheden op relatief grote schaal over de grens werd gewerkt. Bovendien wordt duidelijk dat de grens op een veranderende manier van vitaal belang was voor de kwantitatieve evolutie van de pendelstroom naar Duitsland.

In hoofdstuk 5 staat de beeldvorming rond de grenspendel naar Duitsland in de regionale sociaal-politieke context centraal. Aan de hand van de berichtgeving over grensarbeid in regionale dagbladen wordt geconstateerd dat deze zich binnen enkele decennia ontwikkelde van uitgesproken negatief tot zeer positief. Achter deze kentering ging een verschuivend betekeniskader met betrekking tot (Zuid-)Limburg als grensgebied schuil, dat samenging met een veranderende conceptie van de grens.

Hoofdstuk 6 is het laatste empirische hoofdstuk. Met behulp van interviewmateriaal worden daarin de ervaringen van de grensarbeiders zelf in kaart gebracht. Zij worden gevolgd op weg naar Duitsland, in de dagelijkse praktijk van het werken in Duitsland, en tijdens en na de eventuele beëindiging daarvan. Uit de analyse van de trajecten die deze Duitslandgangers doorliepen, zal blijken dat de ervaringen met het werken in Duitsland en de grens op verschillende manieren met elkaar verbonden waren. Verder zal duidelijk worden dat hierin histo- 
risch gezien, maar ook in de trajecten en tussen verschillende groepen grensarbeiders, verschillen optraden.

In het slothoofdstuk worden de drie invalshoeken met elkaar in verband gebracht en wordt gereflecteerd op de wetenschappelijke en praktische implicaties van de resultaten.

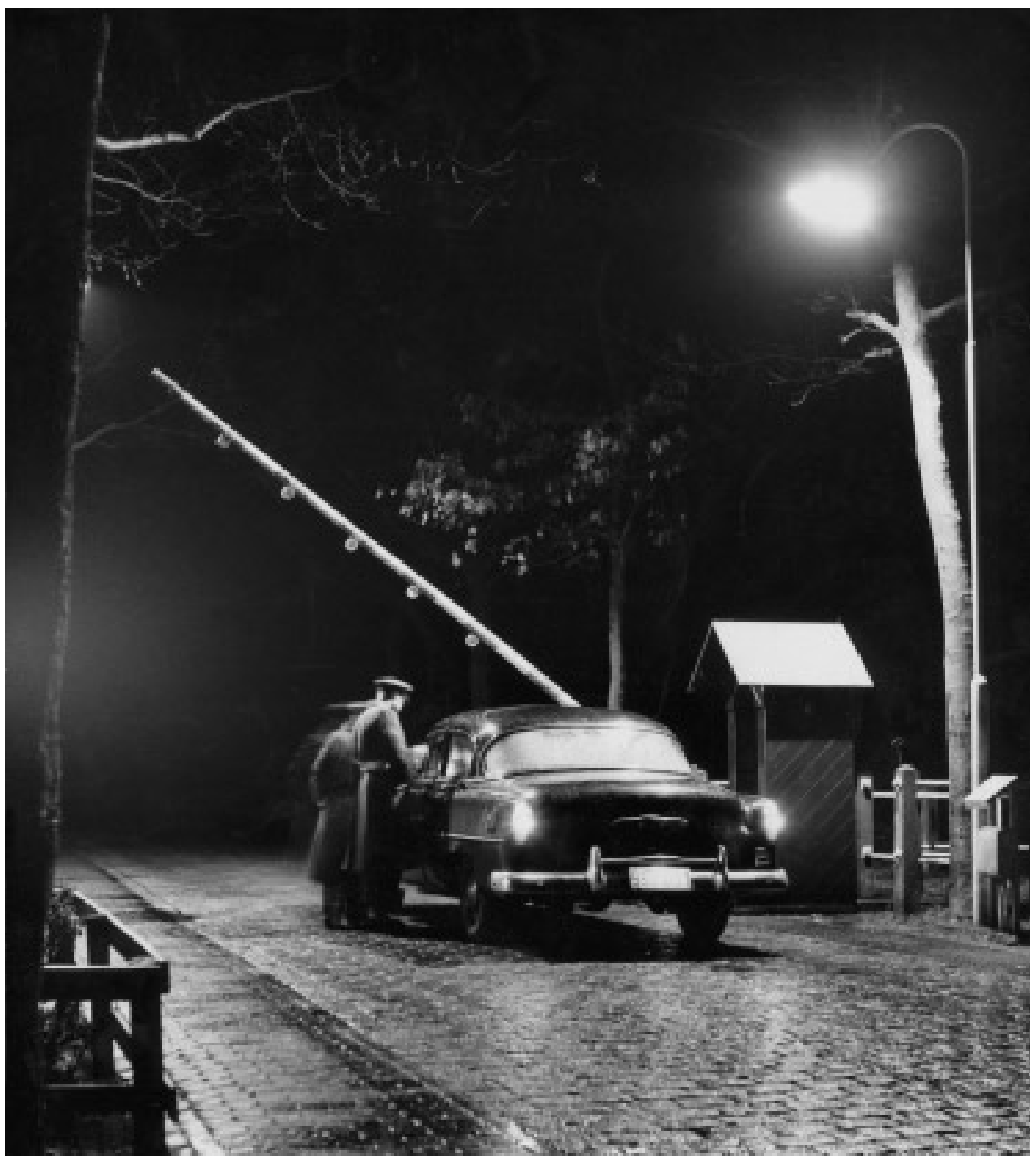

Grenscontrole. Bron: Beeldbank Spaarnestad (foto niet gedateerd). 


\section{Hoofdstuk 2}

\section{Over theoretische en methodologische kaders}

(...) borders cannot be understood within disciplinary boxes. Territorial, institutional, and symbolic borders are constantly emerging, getting reconstructed and contested. No one vantage point can handle the complexities of time and space therein.

Grenzen en grensarbeid zijn het product zijn van verschillende, op elkaar ingrijpende politieke, economische, sociale en culturele processen. Om bij het bestuderen van hun onderlinge relatie recht te doen aan deze complexiteit is het nodig inzichten uit verschillende disciplines met elkaar te combineren en integreren. ${ }^{2}$ In de grensstudies worden disciplinaire grenzen daarom in toenemende mate overschreden. Ook dit onderzoek gaat zowel in theoretisch als methodologisch opzicht uit van een interdisciplinaire benadering. In dit hoofdstuk wordt allereerst de literatuur over grenzen, grensgebieden en grensarbeid besproken die de basis vormt voor de bestudering van de relatie tussen de grenspendel vanuit Zuid-Limburg naar Duitsland en de Nederlands-Duitse grens. Vervolgens wordt de gehanteerde onderzoeksaanpak uiteengezet.

\section{LIJNEN IN DE LITERATUUR}

Sinds de jaren 1990 genieten grenzen steeds meer wetenschappelijke belangstelling. Er is een apart vakgebied ontstaan, de zogenaamde grensstudies, waarin onder meer geografen, antropologen, sociologen, economen, historici en politieke wetenschappers participeren. Inmiddels heeft zich in de grensstudies een aantal belangrijke veranderingen voltrokken. Op de eerste plaats is de conceptie van grenzen verruimd. Zij worden niet meer uitsluitend als territoriale en staatsrechtelijke demarcaties gezien, maar ook als sociale en culturele scheidslijnen. Daarnaast worden ze meer en meer benaderd als sociale constructies, waardoor het accent verschuift van grenzen als statische scheidslijnen naar processen van begrenzing en ontgrenzing. De vernieuwde kijk op grenzen gaat hand in hand met een perspectiefwisseling waarbij zij niet langer vanuit de centra van natiestaten worden bestudeerd, maar vanuit de 'perifere' gebieden aan de grens. ${ }^{3}$ Deze ontwikkelingen vormen het vertrekpunt van dit onderzoek en zullen in de volgende paragrafen nader worden beschreven. Daarna wordt ingegaan op de literatuur over grensarbeid, die hoofdzakelijk handelt over het voorkomen of uitblijven van grensarbeid en verklaringen daarvoor en maar weinig oog heeft voor de langere termijn, en nog minder voor de betekenis die grenspendel krijgt in grensgebieden en onder grensarbeiders.

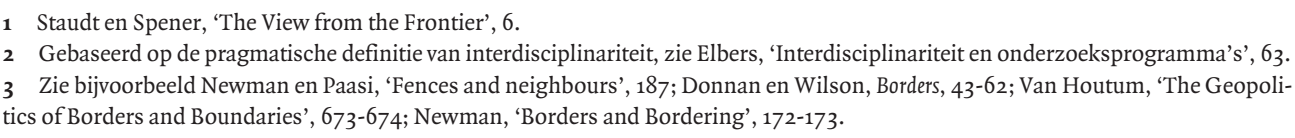




\section{Dimensies en dynamiek van grenzen}

Lange tijd zijn grenzen hoofdzakelijk benaderd als de afbakening van het grondgebied van staten. Dat wordt hier de politiek-materiële dimensie van grenzen genoemd. ${ }^{4}$ In die hoedanigheid zijn grenzen het resultaat van het principe van territorialiteit dat als uitgangspunt fungeerde bij het proces van staatsvorming. Inzet daarbij is mensen en hulpbronnen te controleren en besturen via de constructie van duidelijk afgebakende grondgebieden. ${ }^{5}$ Het beginsel van territoriale soevereiniteit, oftewel autonomie binnen een begrensd grondgebied, was daarbij van wezenlijk belang. Dat principe vormde een belangrijk punt van discussie bij de onderhandelingen in het kader van de Vrede van Westfalen. Sinds het Congres van Wenen in 1814-1815 worden (Europese) grenzen op systematische wijze zichtbaar afgebakend door middel van onder meer grensstenen en -palen. ${ }^{6}$

Dat betekent niet dat grenzen vervolgens voorgoed vastlagen. Vooral als gevolg van oorlogen en andere conflicten en daarop volgende (vredes)onderhandelingen en akkoorden, voltrokken zich nadien nog allerlei grensverschuivingen op de Europese landkaart. ${ }^{7}$ Dat deze wijzigingen ook op relatief vreedzame wijze gestalte konden krijgen is recentelijk gebleken met de val van de Berlijnse Muur en de daaropvolgende hereniging van Oost- en West-Duitsland. Daarbij werd een van de zwaarst bewaakte grenzen in korte tijd opgeheven. Niet alleen het bestaan en de locatie, maar ook de formele open- of geslotenheid van grenzen verandert in de tijd. Ook dat was zichtbaar na de val van de Muur. Het voormalige, vrijwel hermetisch gesloten, IJzeren Gordijn tussen Oost- en West-Europa is sindsdien geopend. Behalve in de tijd kan de doorlaatbaarheid van grenzen voor verschillende sociale groepen variëren en is zij afhankelijk van de richting. ${ }^{8}$ Zo kunnen westerse toeristen de grens tussen Europa en Afrika makkelijk overschrijden, terwijl zij voor Afrikaanse migranten vaak dicht blijft.

In hun politiek-materiële betekenis scheiden grenzen niet alleen twee staatsterritoria, maar ook de bijbehorende politieke en administratieve systemen. Elk land kent zijn eigen bestuurlijke structuur en wet- en regelgeving. Verschillen in bijvoorbeeld economisch en sociaal beleid kunnen ongelijke ontwikkelingen aan weerszijden van de grens teweegbrengen. ${ }^{9} \mathrm{Op}-$ nieuw vormt de voormalige grens tussen West- en Oost-Duitsland een goed voorbeeld. De economie van het socialistische Oost-Duitsland maakte een ontwikkeling door die sterk afweek van die in het liberalere West-Duitsland. Mede als gevolg daarvan bestaat er nu, ruim zeventien jaar na de hereniging, nog een grote economische ongelijkheid tussen beide landsdelen.

Politiek-materiële grenzen zijn het onderzoeksobject van de zogenoemde 'traditionalistische' grensliteratuur en worden daarin ten onrechte benaderd als nogal statische fenomenen. In de hedendaagse grensstudies is er terecht steeds meer oog voor de dynamiek én voor een

4 De geograaf Van Houtum spreekt ook wel van functionele en concrete grenzen (The Development of Cross-Border Economic Relations, 2324, 39-41); de antropologen Wilson en Donnan hanteren de term 'politiek-juridische' grenzen ('Nation, state and identity', 2). De sociologen Staudt en Spener verbinden dit met een 'materialistische' conceptie van grenzen ('The View from the Frontier', 6) en de geograaf Newman heeft het over fysieke scheidslijnen ('Borders and Bordering', 172).

5 Sack, Human territoriality, 19.

6 Knippenberg en Markusse, '19th and 2oth century borders', 2-4.

7 Ibidem, 4-6.

8 Newman en Paasi, 'Fences and neighbours', 197; Van Houtum, The Development of Cross-Border Economic Relations, 19-23; Donnan en Wilson, Borders, o.a. 8-9. Zie ook de typologieën van Martínez (Border People, 6-10) en Baud en Van Schendel ('Toward a Comparative History of Borderlands', 223-225).

9 Knotter, 'Paradoxen van de grens'. 
andere hoedanigheid van grenzen. ${ }^{10}$ Naast staatsgrenzen bestaan er immers minder concrete grenzen tussen sociale groepen en identiteiten. Zij scheiden bijvoorbeeld religieuze, etnische of inkomensgroepen van elkaar. Deze sociaal-culturele grenzen vervullen een cruciale functie bij processen van sociale in- en uitsluiting en identificatie. ${ }^{11}$ Zij markeren wie wel en niet tot een groep behoren. Aangezien identificatie met een groep zowel voortkomt uit gemeenschappelijke kenmerken en gevoelens van eenheid onder leden van de eigen groep als uit het onderscheid van anderen, zijn grenzen hierbij eveneens van groot belang. Door symbolische grenzen te trekken demonstreren sociale groepen en personen wie of wat ze zijn, maar ook wie of wat ze niet zijn. Daarbij ontwikkelen ze tegenidentiteiten, die als contrastbeeld van de eigen identiteit fungeren. Zo ontstaat er een wij-zijrelatie die samengaat met overwegend negatieve, stereotiepe beelden van de 'ander'. ${ }^{12}$

In sociaal-culturele zin worden grenzen geproduceerd en gereproduceerd in sociale praktijken en percepties. Ook in die hoedanigheid zijn zij veranderlijk in termen van hun locatie en doorlaatbaarheid. Zo kan een persoon op het ene moment tot een bepaalde groep behoren, terwijl deze hem later buitensluit. Van de andere kant maakt een en dezelfde persoon tegelijkertijd meestal deel uit van verschillende sociale groepen en heeft hij of zij bijgevolg meerdere identiteiten. Of een persoon tot een bepaalde groep behoort en zich daarmee vereenzelvigt, is behalve van het moment afhankelijk van de ruimtelijke en situationele context. ${ }^{13}$ Een eenvoudig voorbeeld is dat van Turkse Nederlanders die zich tegenover Nederlanders of in Nederland Turk voelen en ook door anderen als zodanig worden gezien. Ten opzichte van Turken in Turkije voelen zij zich daarentegen weer meer Nederlander en worden zij dienovereenkomstig zo gecategoriseerd.

Met de opkomst van het nationalisme hebben politiek-materiële grenzen in Europa geleidelijk aan een sociaal-culturele betekenis gekregen. De ideologie van het nationalisme ontstond ten tijde van de Franse Revolutie en hing samen met processen als industrialisering en verstedelijking. De geograaf Paasi omschrijft een natie als 'a community of people with a common identity, which is typically based on shared cultural values and attachment to a particular territory'. ${ }^{14} \mathrm{Bij}$ het nationalisme staat het streven naar correspondentie tussen natie en staat hoog in het vaandel. ${ }^{15}$ Door de eeuwen heen is die eenheid zowel bewust gesmeed als onbewust gegroeid. Via de verstrengelde processen van staats- en natievorming zijn staten het dagelijks leven van burgers in toenemende mate binnengedrongen. Dat kreeg onder meer zijn beslag in de invoering van de dienstplicht, de centrale regulering van de economie en het creeren van een fysieke en sociale infrastructuur. Het leven van burgers werd zo steeds meer beheerst door de staat waarin zij woonden, en ze raakten nauwer met de staat en met elkaar verbonden. ${ }^{16}$ Ook de introductie van nationale talen, nationaal onderwijs, nationale media en het

\footnotetext{
10 Zie de verwijzing naar de geograaf Ratzel in Van Houtum, 'The Geopolitics of Borders', 673; Newman, 'Borders and Bordering', 174-175; Staudt en Spener, 'The view from the frontier', 14-15.

11 Van Houtum spreekt van 'affectieve' en 'abstracte' grenzen (The Development of Cross-Border Economic Relations, 23-24, 39-41), terwijl Wilson en Donnan het hebben over 'symbolische' grenzen ('Nation, state and identity', 2). Staudt en Spener relateren dit aan een 'metaforische' conceptie van grenzen ('The View from the Frontier', 6) en Newman spreekt net als Van Houtum van een abstracte notie van grenzen ('Borders and Bordering', 172).

12 De sociologe Lamont spreekt ook wel van boundary work (Lamont en Molnár, 'The study of boundaries in the social sciences', 170172; zie ook Lamont, The dignity of working men, 3, 270); zie verder ook het klassieke werk van de antropoloog Barth over de sociale constructie van etnische grenzen ('Introduction', o.a.13).

13 Staudt en Spener, 'The View from the Frontier', 11-13.

14 Paasi, Territories, Boundaries and Consciousness, 39.

15 Gellner, Nations and nationalism, 1; Hobsbawm, 'Mass-Producing Traditions', 264-265.

16 Dit is wat de socioloog Mann 'infrastructurele macht' noemt, zie bijvoorbeeld de verwijzing daarnaar in Knippenberg en Markusse, '19th and 2oth century borders', 7 (Mann, States, War and Capitalism).
} 
kiesrecht, hadden hierin een belangrijk aandeel. ${ }^{17}$ Landgenoten raakten in toenemende mate gehomogeniseerd, genationaliseerd en op elkaar betrokken. Gaandeweg zijn er nationale imagined communities ontstaan, waarvan de leden een zekere onderlinge verwantschap ervaren terwijl zij elkaar lang niet allemaal kennen. ${ }^{18}$ Burgers gingen zich dus primair oriënteren op de natiestaat waarin ze woonden, zich daarmee identificeren en hem en zijn grenzen en passant als legitiem beschouwen. In de woorden van de geograaf Paasi raakten zij 'nationaal gesocialiseerd' ${ }^{19}$

Staatsgrenzen zijn cruciaal voor de ontwikkeling van nationale identiteiten, omdat daarmee wordt bepaald wie wel en niet tot de nationale gemeenschap behoort. Dat ook deze identiteiten niet alleen endogeen vorm krijgen, maar tevens in het onderscheid van 'anderen', blijkt uit het bestaan van talloze stereotiepe beelden van (de bevolking van) andere landen waarmee de eigen nationale identiteit wordt afgebakend. Deze generaliserende en vereenvoudigde beelden kunnen een grote bestendigheid vertonen, maar kunnen onder invloed van economische en politieke veranderingen ook sterk wijzigen. ${ }^{20}$

In de loop der eeuwen zijn politiek-materiële en sociaal-culturele grenzen in Europa dus steeds meer op één lijn komen te liggen. Toch vallen zij lang niet altijd samen. Zelfs toen Europese samenlevingen sinds de negentiende eeuw in versneld tempo werden genationaliseerd, werden het geen volledig homogene en afgesloten gehelen. Zo vallen etnische of taalgrenzen niet altijd samen met staatsgrenzen en kunnen burgers er naast of in plaats van een nationale identiteit onder meer religieuze en regionale identiteiten op nahouden. ${ }^{21}$ Daarnaast zijn staatsgrenzen nooit helemaal af te sluiten. Er is altijd sprake van (legale en/of illegale) grensoverschrijdende mobiliteit van goederen, informatie, kapitaal en/of personen, en dus van externe invloeden. Grenzen zijn dus geen statische en ondoordringbare scheidslijnen tussen staten en 'hun' samenlevingen, maar eerder filters met een sterk variërende mate van open- en geslotenheid in de tijd en de ruimte. ${ }^{22}$ Het dikwijls gehanteerde beeld van natiestaten als waterdichte containers die één samenleving omvatten, houdt dan ook geen stand. ${ }^{23}$

Omdat staatsgrenzen wel een sociaal-culturele betekenis hebben, maar niet noodzakelijkerwijs impermeabele sociaal-culturele scheidslijnen zijn, is het zinvol onderscheid te maken tussen de politiek-materiële en de sociaal-culturele dimensie van staatsgrenzen. Binnen deze dimensies kan er vervolgens weer worden gesproken van bijvoorbeeld respectievelijk institutionele of symbolische aspecten van grenzen. Omdat de politiek-materiële en de sociaal-culturele dimensie van grenzen als twee zijden van dezelfde medaille met elkaar zijn verbonden, worden zij in navolging van de antropologen Wilson en Donnan in onderlinge samenhang bestudeerd. ${ }^{24}$ Ondanks hun nauwe verbinding kunnen grenzen in de twee dimensies een afwijkende dynamiek en porositeit vertonen. Doordat staatsgrenzen dikwijls op arbitraire wijze tot stand zijn gekomen en in veel gevallen zijn verschoven, lopen zij vaak dwars door bestaan-

20 Rose, 'Place and identity', 92-96; Paasi, Territories, Boundaries and Consciousness , 59-61.

21 Hobsbawm, 'Mass-producing traditions', 264-265: volgens hem hebben deze in de loop der tijd wel op nationale wijze gestalte gekregen; Rose, 'Place and identity',89-92.

22 Zie Anderson en O'Dowd, 'Borders, Border Regions and Territoriality', 596, 603.

23 Deze term is geïntroduceerd door de socioloog Giddens die staten met machtscontainers vergeleek (The nation-state and violence, 13) en is aangevuld door de geograaf Taylor die stelde dat staten tevens economische, culturele en sociale containers zijn (geweest) ('The state as container'). Deze metafoor wordt onder meer bekritiseerd door de geograaf Agnew, die spreekt van een 'territorial trap' (Geopolitics, 51).

24 Wilson en Donnan, 'Nation, state and identity', 2; Donnan en Wilson, Borders, 40-41. 
de sociale en culturele betrekkingen en eenheden heen. Deze kunnen vervolgens zijn genationaliseerd, maar daarmee zijn ze niet noodzakelijkerwijs helemaal verdwenen. ${ }^{25}$ Vanwege de fysieke aanwezigheid van grenzen is de incongruentie en de bijbehorende spanning tussen hun politiek-materiële en hun sociaal-culturele dimensie bij uitstek zichtbaar in grensgebieden.

\section{Het perspectief van de 'periferie'}

Het dagelijks leven in grensgebieden is niet los te zien van de grens. Haar aanwezigheid zorgt ervoor dat de regionale bevolking veel met het buurland wordt geconfronteerd en dat grensgebieden vanuit nationaal oogpunt gewoonlijk een perifere ligging hebben. Daardoor onderhouden zij meestal een andere relatie met de natiestaat dan de centraler gelegen delen van het land. De historicus Martínez hanteert de term borderlands milieu om de uniciteit van grensgebieden te duiden. Volgens Martínez verschillen grensstreken op vier punten van centraler in de natiestaat gelegen gebieden. ${ }^{26}$

Allereerst zijn grensgebieden dikwijls omstreden en dus inzet van politieke strijd. De kans bestaat dat verschillende partijen er aanspraak op maken of hebben gemaakt en zij vorm(d)en dan ook geregeld de frontlinie in oorlogen. Het zijn daarmee vaak gebieden waar staten zich sterk willen doen gelden, maar waar zij tegelijkertijd het meest onder vuur liggen. Spanningen tussen de buurlanden kunnen onzekerheid en wantrouwen tegenover de bevolking aan de overzijde van de grens in de hand werken. Daarnaast is het nationale beleid niet altijd toegesneden op de belangen en behoeften van grensbewoners, waardoor er frictie kan bestaan tussen grensgebieden en nationale overheden ten aanzien van bijvoorbeeld accijnzen en protectiemaatregelen. ${ }^{27}$ Zo voelen benzinepomphouders in Nederlandse grensstreken zich gedupeerd door de betrekkelijk hoge accijnzen die de overheid op benzine heft, omdat grensbewoners er daardoor voor kiezen om in België of Duitsland te gaan tanken.

Ten tweede zijn grensgebieden altijd het toneel van grensoverschrijdende interactie. De omvang daarvan is onder meer afhankelijk van de mate van open- of geslotenheid van de grens en de intensiteit van centripetale en centrifugale krachten, die grensbewoners respectievelijk het land in trekken of over de grens heen duwen..$^{28}$ De aanwezigheid van een grens kan grensoverschrijdende contacten en mobiliteit belemmeren, maar eveneens stimuleren. Doordat zij twee politieke systemen van elkaar scheidt, kunnen zich ongelijke ontwikkelingen voordoen op bijvoorbeeld economisch en cultureel gebied, die het aantrekkelijk maken haar te overschrijden. Juist omdat de grens een scheidslijn is, kan zij dan als verbindingslijn fungeren. De historicus Knotter noemt dit mechanisme de 'paradox van de grens'. ${ }^{29}$

Mede als gevolg van de genoemde eigenschappen van grensgebieden kennen zij op de derde plaats doorgaans een hoge mate van culturele diversiteit. Hun bevolking is in religieus, etnisch en taalkundig opzicht veelal heterogener samengesteld dan die in centraler gelegen de-

25 Strassoldo, 'Boundaries in Sociological Theory', 259; Leerssen, Europe as a set of borders', 10-11; Anderson en O'Dowd, 'Borders, Border Regions and Territoriality', 595-596.

26 Martínez, Border People, 10-25.

27 Ibidem 13-16.

28 Ibidem, 10-13; Van Houtum, The Development of Cross-Border Economic Relations, 16-17.

29 Knotter, 'Paradoxen van de grens', 161; vgl. Baud en Van Schendel, 'Toward a Comparative History of Borderlands', 229-231; zie ook een onderzoek naar het Nederlands-Duitse grensgebied Achterhoek-Borken uit 1970, waarin dit idee reeds in embryonale vorm aanwezig leek (Mrohs en Heukels, Die Grenze - Trennung oder Begegnung). 
len van natiestaten. Zo kunnen leden van de nationaal gezien dominante etnische of religieuze groepering er samenleven met lokale etnische of religieuze minderheden, die door de grens van hun eigen groep zijn afgesneden, wat mogelijkerwijs spanningen met zich meebrengt. ${ }^{30}$

Dit alles zorgt er ten vierde voor dat bewoners van grensgebieden meestal een ambivalente relatie onderhouden met het land waarin ze wonen. Vanwege de unieke omstandigheden waarin zij leven, en hun mogelijk afwijkende lokale cultuur, geschiedenis en belangen, identificeren zij zich lang niet altijd even sterk met de rest van het land en worden zij vaak ook als anders gezien. Zij bevinden zich niet zelden in een spagaat tussen hun eigen land en het land aan de overzijde van de grens en vertonen dikwijls tegenstrijdige praktijken en loyaliteiten die de grens, en daarmee het gezag van de natiestaat, kunnen ondermijnen. ${ }^{31}$

Omdat grensgebieden gewoonlijk worden getypeerd als perifeer is het van belang te benadrukken dat grensbewoners geen passieve en willoze subjecten zijn, wier lot volledig in handen van centrale overheden ligt. Integendeel, zij zijn actieve agents, die hun leven ook zelf kunnen vormgeven en daarbij de staat en haar grenzen kunnen beïnvloeden. De geograaf Anderson en de socioloog O'Dowd verwoorden het als volgt: 'Territorial borders both shape and are shaped by what they contain, and what crosses or is prevented from crossing them.' ${ }^{22}$ Met zijn klassieke studie in de Cerdanya, een deel van Catalonië dat met de Vrede van de Pyreneeën in 1659 werd opgesplitst in een Frans en een Spaans deel, heeft de historicus Sahlins laten zien dat lokale gemeenschappen een actieve rol speelden bij de totstandkoming en het voortbestaan van de Spaans-Franse grens aldaar. Gezien de wisselwerking tussen staten en grensgebieden kan er dus eigenlijk niet van centrum en periferie worden gesproken, omdat dit een te hiërarchische relatie impliceert. ${ }^{33}$

Grenzen zijn vaak vanuit het centrum van natiestaten bestudeerd. Dat brengt het gevaar met zich mee dat zij als de nogal statische en onbetwiste markeringen van hun territoriale bereik worden beschouwd. In dat geval wordt de spanning tussen de nationale ideologie en de mogelijk afwijkende praktijken en oriëntaties van grensbewoners onvoldoende (h)erkend. Om recht te doen aan de agency van de grensbevolking is een perspectief vanuit de 'periferie' en een benadering 'van onderop' onmisbaar. ${ }^{34}$ De antropologen Wilson en Donnan hanteren een definitie van grensgebieden die rekening houdt met de wisselwerking tussen natiestaten en grensbewoners. Zij gebruiken de term frontiers die zij omschrijven als 'territorial zones of varying width which stretch across and away from borders, within which people negotiate a variety of behaviours and meanings associated with their membership of nations and states' ${ }^{35}$ Hoewel dit onderzoek zich concentreert op het grensgebied aan één zijde van de grens, zijn de bovengenoemde kenmerken en processen ook hierop van toepassing en zeker bruikbaar bij het analyseren van grensoverschrijdende mobiliteit.

Grensgebieden vertonen een aantal gemeenschappelijke eigenschappen. Desalniettemin kan hun karakter afhankelijk van de temporele en ruimtelijke context sterk verschillen. Zo kan

\footnotetext{
30 Uiteraard wonen er ook veel etnische minderheden in de centraler gelegen grote steden, maar deze zijn veelal later naar het betreffende land gemigreerd, terwijl de minderheden in grensgebieden daar vaak al woonden op het moment dat de grens werd getrokken. 31 Martínez, Border People, 18-21; Stoddard, 'Frontiers, Borders and Border Segmentation', 8-9; Strassoldo, 'Border Studies', 385 ; Wilson en Donnan, 'Nation, state and identity', 10-11.

32 Anderson en O'Dowd, 'Borders, Border Regions and Territoriality', 594.

33 Sahlins, Boundaries, 8; Idem, 'State formation and national identity'.

34 Bijv. Leerssen, 'Europe as a set of borders', 7; Baud en Van Schendel, 'Toward a Comparative History of Borderlands', 212; Donnan en Haller, 'Liminal no more', 10-11.

35 Wilson en Donnan, 'Nation, state and identity', 9.
} 
er variatie bestaan in de openheid van grenzen en in de intensiteit van centrifugale en centripetale krachten. ${ }^{36}$ In Europa is sinds de jaren 1950 'van bovenaf' getracht de binnengrenzen van de huidige Europese Unie (EU) geleidelijk aan te openen. Maar terwijl deze grenzen in hun politiek-materiële dimensie aan relevantie inboetten, wonnen zij tegelijkertijd aan belang door de uitbouw van de nationale verzorgingsstaten. In de jaren 1970 bereikten veel welvaartsstaten hun grootste omvang. Bij de herziening van de sociale stelsels in de periode daarna borduurden zij echter voort op de bestaande situatie. Deze padafhankelijkheid heeft de verzorgingsarrangementen er niet minder complex op gemaakt en burgers in die zin alleen maar meer aan hun land gebonden. ${ }^{37}$

Met name sinds de totstandkoming van de Europese eenheidsmarkt wordt er ook op regionaal niveau samengewerkt om de barrièrewerking van grenzen teniet te doen. Een van de belangrijkste vormen van interregionale samenwerking zijn de in hoofdstuk 1 beschreven Euregio's, die vanaf het begin van de jaren 1990 middels de zogenaamde INTERREG-gelden steun ontvangen van de Europese Commissie. Van deze 'laboratoria van Europese integratie' wordt een katalysatorfunctie verwacht in het eenwordingsproces..$^{38}$ Ofschoon dergelijke samenwerkingsverbanden vooral een functionele inslag hebben en gericht zijn op bijvoorbeeld economische, infrastructurele en culturele projecten, stelt politiek-wetenschapper Keating dat '[...] they also have a strong political component, founded on the desire of regional politicians to project themselves on a wider stage, or to escape the restrictions of national politics'. ${ }^{39}$ Nochtans blijkt dit grensoverschrijdend regionalisme nauwelijks een voet aan de grond te krijgen. Dat is gedeeltelijk verbonden met de wat dubbelzinnige wijze waarop centrale overheden de Euregio's benaderen. Enerzijds willen ze economische ontwikkeling in deze regio's, mede door middel van de inzet van EU-gelden, stimuleren. Anderzijds willen ze geen macht afstaan aan deze organen, waardoor de samenwerking wordt bemoeilijkt. ${ }^{40}$ Bovendien vinden de Euregio's onvoldoende aansluiting bij de lokale bevolking en blijken grenzen in het dagelijks leven en de hoofden van de grensbewoners taaier dan Euregionale beleidsmakers lijken aan te nemen..$^{4}$

\section{Grensarbeid(ers) als grensgeval(len)}

In dit boek wordt via een intensieve studie van de grensarbeid vanuit Zuid-Limburg naar Duitsland inzicht verkregen in de betekenis van de Nederlands-Duitse grens voor Zuid-Limburg. Grensarbeiders zijn personen die op het grondgebied van het ene land wonen en in loondienst op het grondgebied van het andere land werken en dagelijks dan wel wekelijks

\footnotetext{
36 Er bestaan dan ook diverse typologieën om grensgebieden te categoriseren. De meest bekende is het continuüm van Martínez dat betrekking heeft op grensgebieden aan weerszijden van grenzen en loopt van vervreemde, via coëxistente en interdependente, naar geïntegreerde grensgebieden (Martínez, Border People, 6-10). Deze categorieën zijn ideaaltypen en Martínez geeft dan ook aan dat zij in werkelijkheid nooit exact op deze wijze terugkomen, maar dat er meestal sprake is van overlap. Daarnaast wijst hij erop dat zijn typologie geen unilineair ontwikkelingsmodel is. Voor de historici Baud en Van Schendel vormde de typologie van Martínez de inspiratiebron om een dynamische typologie van grensgebieden te ontwikkelen die is gebaseerd op het idee van een levensloop, waarbij grensgebieden zich in vijf stappen ontwikkelen van 'kind' tot 'volwassene' tot 'overledene' (Baud en Van Schendel, 1997, 223-225).

37 Vgl. Esping-Andersen, 'After the Golden Age?', 10-20.

$3^{8}$ Scott, 'Euroregions, Governance and Transborder Cooperation', 106; Van Houtum, 'An Overview of European Geographical Research', 66; Corvers, 'De visie op grensregio's', 18.

39 Keating, The New Regionalism, 181.

40 Van Houtum, 'An Overview of European Geographical Research', 66; Kramsch, 'Re-imagining the 'Scalar-Fix”, $225,228$.

41 Scott, 'Euroregions, Governance and Transborder Cooperation', 112-115; over de Euregio Rijn-Waal, zie Strüver, 'We are only allowed to re-act', 34-35.
} 
naar huis terugkeren. ${ }^{42}$ Grenspendel onderscheidt zich van andere vormen van grensoverschrijdende arbeidsmobiliteit, zoals permanente of tijdelijke arbeidsmigratie, doordat het doorgaans over kortere afstanden plaatsvindt en het woonland gewoonlijk niet verandert. ${ }^{43}$

Grensoverschrijdende mobiliteit raakt altijd aan zowel de politiek-materiële als de sociaalculturele dimensie van grenzen. ${ }^{44}$ Dat geldt in het bijzonder voor grensarbeid. Grensforensen overschrijden met grote regelmaat de territoriale grens tussen twee landen. Daardoor onttrekken zij zich gedeeltelijk aan het gezag van hun woonland, en zijn ze ten dele onderworpen aan de wet- en regelgeving van het werkland. Verder behelst grensarbeid relatief frequente en nauwe contacten met de bevolking van het buurland, waardoor de sociaal-culturele dimensie van de grens eveneens onmiskenbaar aanwezig is. Grenspendelaars worden niet alleen vrijwel dagelijks met inwoners van het buurland geconfronteerd, maar werken tevens met hen samen. Deze betrekkelijk intensieve interactie met de bevolking aan de overzijde van de grens kan het onderscheid tussen het nationale 'wij' en 'zij' doen vervagen. ${ }^{45}$

Grensbewoners die naar de andere kant van de grens verhuizen, bevinden zich in een vergelijkbare situatie. Zij komen echter niet noodzakelijkerwijs even intensief in aanraking met de bevolking van hun nieuwe woonland als grensarbeiders met de bevolking van hun werkland. De geografe Strüver heeft onderzoek gedaan naar de zogenaamde Nederduitsers, Nederlanders die vanwege de gunstige Duitse woningmarkt en de mogelijkheid om sinds 2001 de hypotheekrente van de belasting af te trekken als ze in Nederland werken, de laatste jaren in groten getale in het Duitse grensgebied zijn neergestreken. Zij heeft daarbij laten zien dat hun verhuizing niet automatisch betekent dat zij veel contact hebben met Duitsers. Het dagelijks leven van de Nederduitsers blijft zich grotendeels aan Nederlandse zijde van de grens afspelen en in Duitsland zoeken zij elkaar vaak op..$^{6}$

Grensarbeiders zijn te typeren als 'grensgevallen'. ${ }^{47}$ Die term benadrukt allereerst de nabijheid en het belang van de grens in beide dimensies. Bovendien verwijst hij naar de tussenpositie waarin grensarbeiders zich bevinden. Zij bewegen voortdurend heen en weer tussen twee landen. Door dit laveren tussen twee nationale contexten belichamen ze de spanning tussen grensoverschrijdende praktijken en oriëntaties en de grenzen van de natiestaat, die het dagelijks leven in grensgebieden kenmerkt..$^{8}$

Hieronder wordt verder ingegaan op de drie aspecten van grensarbeid die in deze studie centraal staan: de totstandkoming of het uitblijven van grenspendel, en de individuele ervaring van en regionale beeldvorming rond grensarbeid.

\footnotetext{
42 Op basis van de definitie van het CBS, zie bijvoorbeeld Sociale Maandstatistiek 1998/02, 47. Afstand speelt hierbij geen rol en personen die voor werkgevers gevestigd in het woonland werken, zijn hier zo veel mogelijk buiten beschouwing gelaten.

43 Grensarbeid kan ook het resultaat zijn van een verhuizing naar het buurland waarbij werk in het land van herkomst wordt aangehouden. Het betreft dan echter verhuismobiliteit in plaats van arbeidsmobiliteit. Deze 'a-typische' vorm van grensarbeid wordt in dit onderzoek zo veel mogelijk buiten beschouwing gelaten (zie http://www.emr-taskforce.org/nl/news.shtml).

44 Donnan en Wilson, Borders, 107-108.

45 Ibidem, 107 .

46 Strüver, 'Spheres of Transnationalism'; zie ook Van Houtum en Gielis, 'Elastic Migration'. Overigens kan grensoverschrijdend studeren wel nauwe contacten met de bevolking van het buurland impliceren, maar heeft dit bij voorbaat een tijdelijk karakter terwijl grensarbeid in principe langere tijd kan aanhouden.

47 Vgl. Knotter die de term op een andere manier gebruikt: hij spreekt van 'de creatie van grensgevallen' indien er sprake is van culturele vermenging in grensgebieden ('Paradoxen van de grens', 170-171; op basis van Leerssen, 'Europe as a set of borders', 14). 48 De manier waarop de term 'grensgevallen' hier wordt gebruikt is verwant aan de term 'transnationale grensbewoners' die Martínez in zijn boek over het Mexicaans-Amerikaanse grensgebied onder meer voor grensarbeiders gebruikt. 'Grensgevallen' legt echter meer de nadruk op de tussenpositie waar de grensarbeiders zich in bevinden en verwijst in één woord naar het belang van de grens (Border People, 62-63).
} 
De literatuur over grensarbeid richt zich hoofdzakelijk op het totstandkomen of uitblijven ervan. Economen besteden daarbij met name aandacht aan de politiek-materiële dimensie van grenzen. Grenspendel ontstaat dan doordat grensbewoners reageren op vooral sociaal-economische push- en pullfactoren. Daarbij valt te denken aan de vraag naar werknemers, de werkloosheid en loonverschillen. Daarnaast onderscheiden zij interveniërende variabelen of transactiekosten die met de grens samenhangen, zoals institutionele discrepanties, taalverschillen en een gebrek aan informatie. ${ }^{49}$ Verschillen in wet- en regelgeving en (daar dikwijls mee verbonden) ongelijke sociaal-economische ontwikkelingen, kunnen evenwel ook een stimulans zijn om de grens te overschrijden. Indien zij grensbewoners ertoe aanzetten om over de grens te gaan werken, is er sprake van de eerder genoemde paradox van de grens. ${ }^{50}$

Hoewel werken over grenzen economische voordelen kan bieden en er diverse maatregelen zijn genomen om fysieke en institutionele barrières te slechten, is het aantal grensarbeiders in Europa gedurende de afgelopen dertig jaar erg klein gebleven. Er bestaan daarbij wel regionale verschillen. Zo werd er zowel in de jaren 1970 als in de jaren 1990 op relatief grote schaal vanuit Frankrijk naar Duitsland gependeld (door enkele tienduizenden personen), terwijl er bijvoorbeeld vanuit Denemarken amper in Duitsland werd gewerkt (door nog geen tweeduizend personen)..$^{51}$ Niettemin is het algemene beeld dat de groeiende mogelijkheden tot grenswerk amper worden benut. Recente studies concentreren zich daarom op de achtergronden van de vrijwel uitblijvende Europese grenspendel. Die worden hoofdzakelijk gezocht in 'zachte' factoren verbonden met de sociaal-culturele dimensie van de grens. Mentale, sociale en culturele barrières staan grensarbeid dan in de weg. Deze literatuur biedt waardevolle inzichten. Zij vult een structuralistisch perspectief aan met een handelingsperspectief, dat meer recht doet aan de mate waarin grensbewoners hun gedrag zelf kunnen vormgeven. Bovendien erkennen de betreffende auteurs doorgaans dat het menselijk handelen gedeeltelijk voortkomt uit onbewuste en emotionele processen en dus niet alleen het resultaat is van kosten- en batenafwegingen..$^{52}$

Nadeel van de recente literatuur over de achtergronden en oorzaken van zowel mobiliteit als immobiliteit is dat de betreffende auteurs zich meestal beperken tot de contemporaine situatie. Daardoor blijft de dynamiek van de verhouding tussen de grensoverschrijdende (im)mobiliteit en de grens verborgen. De geografe Soutif bekeek de ontwikkeling van grensarbeid in Europa wel over ongeveer drie decennia tot 1995, maar schetste een globaal beeld en had dus weinig aandacht voor de specifieke kenmerken en achtergronden van de diverse pendelstromen. ${ }^{53}$ Dit onderzoek onderscheidt zich van eerdere studies door de kwantitatieve ontwikkeling van één grensoverschrijdende pendelstroom, namelijk die vanuit Zuid-Limburg naar Duitsland, diepgaand en over een langere termijn te analyseren. ${ }^{54} \mathrm{Er}$ is daarbij zowel aan-

\footnotetext{
49 De Gijsel et al., 'Concepts and Issues', 9-11; Voor een voorbeeld daarvan, zie: Hanssen en Nahrstedt, 'Cross-Border Commuting'. Vgl. de 'flow'-benadering die Van Houtum binnen de Europese geografische grensstudies onderscheidt ('An Overview of European Geographical Research', 59-62).

50 Knotter, 'Paradoxen van de grens', 161.

51 Ricq, Les travailleurs frontaliers en Europe, 8-13, 66-67; Soutif, L'intégration européenne, 37-41, 361-363; Janssen, 'Borders and labourmarket integration', 51-52; Van Houtum en Van der Velde, 'The power of labour market immobility', 102-103.

52 De Gijsel et al. 'Concepts and Issues', 11-12; Janssen, 'Borders and labour-market integration', 50; Strüver, 'Significant insignificance', 24-25; Van Houtum en Van der Velde, 'The power of labour market immobility', 104-105; Van der Velde en Van Houtum, 'Depoliticizing labour market indifference', 47-50. Vgl. de 'people'-benadering die Van Houtum onderscheidt ('An Overview of European Geographical Research', 67-72).

53 Soutif, L'intégration européenne.

54 Boutillier et al. onderzochten wel de arbeids- en kapitaalstromen tussen België en (Noord-)Frankrijk vanaf de negentiende eeuw (Frontaliers du Nord).
} 
dacht voor de structurele achtergronden van de grenspendel als voor de totstandkoming van de grenspendel op individueel niveau. De evolutie van de omvang en samenstelling van deze pendelstroom wordt in hoofdstuk 4 gerelateerd aan regionale sociaal-economische ontwikkelingen aan weerszijden van de grens. In dat gedeelte van het onderzoek staat de politiekmateriële dimensie van de grens centraal. In hoofdstuk 6 wordt op het individuele niveau van de grensarbeiders nagegaan hoe en waarom zij door de jaren heen in Duitsland gingen werken en hoe zich dit ook tot de grens in haar sociaal-culturele dimensie verhield.

Een andere blinde vlek in de grensstudies betreft de vraag wat er gebeurt zodra grensbewoners de beslissing hebben genomen om over de grens te gaan werken. ${ }^{55}$ Hoe wordt er op individueel en regionaal niveau omgegaan met de spanning tussen de grensoverschrijding en de grens die in de grenspendel besloten ligt? Oftewel, hoe verhield de grensoverschrijdende arbeidsmobiliteit zich in de ervaringen van de grensarbeiders tot de grens? En hoe werd de grenspendel in het grensgebied beoordeeld? Ook op deze vragen zal dit onderzoek nader ingaan.

\section{Individuele ervaringen}

Om de ervaringen met de grenspendel op het individuele niveau van de grensarbeiders te onderzoeken is onder meer de interactie met collega's uit het buurland van belang. Waar het gaat om cultuurverschillen op de werkvloer wordt regelmatig geput uit het werk van de socioloog Hofstede. Hij hanteert echter een essentialistische benadering van nationale culturen als statische, duidelijk afgebakende en uniforme gehelen. ${ }^{56}$ Zoals we zagen, blijkt juist in grensgebieden dat het beeld van nationale staten als homogene en hermetisch afgesloten containers niet standhoudt. Het is vruchtbaarder uit te gaan van de manier waarop al dan niet bestaande cultuurverschillen worden ervaren. Hierin wordt de geograaf Paasi gevolgd, die stelt: 'the problem is not whether or not 'national characters' or other stereotypes exist or not, but whether people believe in their existence, making their observations and distinctions on this basis and acting accordingly'. ${ }^{77}$ Het gaat dus niet zozeer om 'objectieve' cultuurverschillen als wel om de perceptie daarvan op basis waarvan vervolgens wordt gehandeld.

Tot dusver is er in Europa weinig onderzoek verricht naar de manier waarop grensarbeiders gestalte en betekenis geven aan de grenspendel, waaronder hun contacten met collega's uit het buurland. De spaarzame studies op dit terrein betreffen bovendien vrijwel uitsluitend momentopnames. Recentelijk hebben de geografen Dörrenbacher en Schulz enige aandacht besteed aan de samenwerking tussen Franse grensarbeiders en hun Duitse collega's in Saarland-Lotharingen. Daar blijkt de grens als gevolg van taalproblemen en via een ongelijke behandeling op de werkvloer te worden gereproduceerd..$^{8}$ Antropologen hebben de samenwerking tussen personen met verschillende nationale achtergronden nauwgezetter bestudeerd. Zij analyseren de onderlinge contacten en de manier waarop deze zich tot nationale grenzen verhouden en concluderen dat nationale stereotypen, en dus symbolische aspecten van gren-

\footnotetext{
55 De economen Fischer en Straubhaar doen wel onderzoek naar regionaal-economische effecten van grensoverschrijdende arbeidsmigratie in Europa ('The Impact of Mobility on Regional Development'); verder kijkt de antropoloog Heyman vooral naar de formatie van een arbeidersklasse aan de Amerikaans-Mexicaanse grens (Life and Labor on the Border). Ook is er veel onderzoek verricht naar de juridische positie van grensarbeiders (zie bijv. Weerepas, 'Grensoverschrijdende Arbeid in de Euregio'; O'Keeffe, 'Freedom of movement for workers in Community law).

56 Hofstede, Culture's Consequences; Hofstede et al. Grensoverschrijdende politiesamenwerking; zie onder meer de kritiek van de literatuurwetenschapper Leerssen op Hofstedes benadering in 'Over nationale identiteit', 418-425.

57 Paasi, Territories, boundaries and consciousness, 61.

58 Dörrenbacher en Schulz, 'Cultural and regional integration', 135; zie ook idem, 'Economic integration in the Saar-Lorraine border region', 12 .
} 
zen, de onderlinge omgang en de individuele interpretatie daarvan in hoge mate kunnen domineren. ${ }^{59}$ Afgezien van deze studies blijkt de dagelijkse praktijk van het grenswerk in de Europese grensstudies geen kernthema van onderzoek te zijn. ${ }^{60}$

Op basis van zijn onderzoek in het, weliswaar van de Europese grensgebieden afwijkende, Mexicaans-Amerikaanse grensgebied stelt de eerder aangehaalde historicus Martínez dat grensarbeiders elementen uit het dagelijks leven aan weerszijden van de grens met elkaar verweven, maar dat zij zich hoofdzakelijk met hun 'vaderland' (blijven) identificeren. ${ }^{6}$ Ook de socioloog Vila maakt duidelijk dat er daar, naast grensoverschrijding en hybridisering, sprake kan zijn van een verharding van de grens in haar sociaal-culturele dimensie. ${ }^{62}$

In zijn bekende werk over etnische groepen en grenzen, waarnaar veelvuldig wordt verwezen in de grensstudies, kwam de antropoloog Barth eerder al tot vergelijkbare constateringen. $\mathrm{Bij}$ (ook intensieve) ontmoetingen met leden van een andere groep kunnen bestaande groepsgrenzen worden gehandhaafd doordat de betrokkenen hun ervaringen in het sjabloon van het bijbehorende begrensde referentiekader persen. Op die manier kunnen sociale categorieën zichzelf bevestigen. ${ }^{63}$

\section{Regionale beeldvorming}

Het regionaal sociaal-economische perspectief en de invalshoek van de individuele grensarbeiders geven maar beperkt zicht op de betekenis van de grens voor het dagelijks leven in het grensgebied. Om een beeld te krijgen van de betekenissen die de grenspendel in de omringende samenleving kreeg, is het zinvol de analyse van dit fenomeen aan te vullen met een regionaal sociaal-politiek perspectief. Het gaat er dan om hoe verschillende politieke en andere sociale groepen in de omringende samenleving de grenspendel evalueren. Hoe typeren zij de grenspendel in het regionale publieke domein, welke argumenten worden daarbij gehanteerd, veranderde dit, en hoe verhield dit alles zich tot de grens? De beeldvorming rond grensarbeid in de regionale publieke sfeer werpt licht op de (gewenste) relatie tussen het betreffende grensgebied en de natiestaat, en daarmee op de betekenis van de grens.

In de grensstudies is onderzoek naar de regionale beeldvorming rond grensoverschrijdende mobiliteit vrijwel onontgonnen terrein. Strüver analyseert weliswaar columns over Nederduitsers die in een Nederlands regionaal dagblad verschenen, maar die zijn uitsluitend afkomstig van een Nederduitser zelf en vertegenwoordigen dus niet de algemene beeldvorming. Voorts behelst haar onderzoek slechts een korte periode. ${ }^{64}$ In deze studie wordt een diepgaande analyse gemaakt van de ontwikkeling van de beeldvorming rond de grensarbeiders op regionaal niveau.

59 Over de samenwerking tussen Poolse en Duitse douaniers: zie Schwell, 'Living in a Box'; over de samenwerking tussen personen met verschillende nationaliteiten bij de European Space Agency: zie Zabusky, 'Boundaries at work'.

6o Anderen verwijzen kort naar cijfers over grensoverschrijdende mobiliteit en grensoverschrijdende huwelijken als indicatie voor sociale integratie. Het gaat dan echter niet zozeer over de dagelijkse ervaring van het werken over de grens als wel om de effecten daarvan. Bovendien lijkt er geen eenduidig verband te bestaan tussen beide (Van Wettere-Verhasselt, 'Aspecten van menselijke aardrijkskunde', 416; Baycroft, 'Changing identities', 427-428).

61 Martínez, Border People, 62-63, 306-307. De situatie in het Mexicaans-Amerikaanse grensgebied wijkt sterk af van de situatie in (intra-)Europese grensgebieden vanwege de onder meer in economisch opzicht buitengewoon asymmetrische verhouding tussen de Verenigde Staten en Mexico.

62 Vila, Crossing Borders, Reinforcing Borders, o.a. 9.

63 Barth, 'Introduction', 30-31. Pas wanneer de categorisering volkomen inadequaat blijkt en/of niet meer van belang is voor de betreffende etnische groep(en), worden de bestaande indelingen volgens Barth aangepast.

64 Zie Strüver, 'Transnational spheres'; om een zicht te krijgen op de wederzijdse beeldvorming tussen Nederland en Duits onderzoekt zij verder illustraties bij krantenartikelen uit Nederlandse en Duitse landelijke en regionale dagbladen over een tentoonstelling over Nederlands-Duitse relaties sinds het einde van de Tweede Wereldoorlog (zie Strüver, 'Significant Insignificance', 30-32). 
De verhouding tussen grensarbeid en de grens wordt hier dus op drie manieren bestudeerd: vanuit regionaal sociaal-economisch perspectief, vanuit regionaal sociaal-politiek perspectief en op het individuele niveau van de grenspendelaars. Afhankelijk van de invalshoek verschuift het accent van de politiek-materiële naar de sociaal-culturele dimensie van de grens. In het deel over de kwantitatieve ontwikkeling van de grenspendel in relatie tot de regionale arbeidsmarktomstandigheden gaat de aandacht hoofdzakelijk uit naar de politiek-materiële grens. In de gedeelten over de betekenisgeving aan de grenspendel op regionaal niveau en door de grensarbeiders zelf is er meer aandacht voor de sociaal-culturele dimensie van de grens.

\section{ONDERZOEKSAANPAK}

Om de Duitslandpendel uit Zuid-Limburg vanuit de onderscheiden invalshoeken te bestuderen, is gebruik gemaakt van verschillende soorten onderzoeksmateriaal, namelijk statistiek en eerder verschenen publicaties over grensarbeid en sociaal-economische ontwikkelingen aan weerszijden van de grens, krantenartikelen en retrospectieve interviews. Deze vereisen elk een andere aanpak die hieronder uiteen wordt gezet.

\section{Beschrijvende statistiek}

Geaggregeerd cijfermateriaal verschaft inzicht in het gedrag van groepen mensen en de structurele achtergronden daarvan. ${ }^{65}$ Het is bij uitstek geschikt om in kaart te brengen hoe de omvang en samenstelling van de pendelstroom zijn geëvolueerd in relatie tot ontwikkelingen in de sociaal-economische context. Daartoe is zowel gebruik gemaakt van Nederlandse als van Duitse statistieken. Beiden kennen hun beperkingen en ze zijn niet één op één te vergelijken, bijvoorbeeld als gevolg van afwijkende gebiedsindelingen of definities. Toch geven ze een goede indicatie van de ontwikkeling van de pendelstroom, zeker wanneer er rekening wordt gehouden met de wijze waarop de betreffende cijfers zijn verzameld. In appendix A wordt het gebruikte materiaal nader op zijn merites beoordeeld.

Om zicht te krijgen op ontwikkelingen in de sociaal-economische context is gebruik gemaakt van cijfers en beschrijvingen uit, veelal contemporaine, rapporten en literatuur over de arbeidsmarktsituatie aan Nederlandse en Duitse zijde van de grens. Ook daarbij is de vergelijkbaarheid van het cijfermateriaal niet optimaal. Sinds 1989 publiceert het Economisch Technologisch Instituut Limburg (ETIL) geharmoniseerde cijfers over de arbeidsmarktontwikkeling in alle delen van de Euregio Maas-Rijn (EMR) waar Zuid-Limburg en de aangrenzende Regio Aken deel van uitmaken. ${ }^{66}$ Vanaf dat moment zijn deze als referentiepunt genomen voor de ontwikkeling van de arbeidsmarkten aan weerszijden van de grens.

Aan de hand van de cijfers, de achtergrondinformatie over sociaal-economische ontwikkelingen aan weerszijden van de grens en andere studies naar de achtergronden van het voorkomen of uitblijven van grensarbeid, is het mogelijk een analyse te maken van de manier waarop de kwantitatieve ontwikkeling van de grenspendel zich tot de grens verhield. Zij zeggen echter weinig over de precieze motivaties en eventuele belemmeringen zoals de grensarbeiders die ervoeren, laat staan over hoe het werken in Duitsland in de praktijk vorm kreeg en in

65 Swanborn, Methoden van sociaal-wetenschappelijk onderzoek, 216-217.

66 In haar jaarlijkse Limburgse Sociaal-Economische Verkenning en diens opvolger Limburg in Beeld. 
de regionale sociaal-politieke context werd geëvalueerd. Om hier inzicht in te verwerven is ander materiaal verzameld, te weten krantenberichten en interviewmateriaal.

\section{Krantenartikelen}

De communicatiewetenschapper Wester noemt mediamateriaal een 'maatschappelijk memo'. ${ }^{67}$ Het biedt een venster op heersende denkbeelden en normen in een bepaalde ruimtelijke en historische context. De inhoud van media is niet alleen een spiegel, maar tevens een bron van maatschappelijke betekenisgeving en transformatie. ${ }^{68}$ Media vormen een platform waar verschillende partijen, zoals politici, belangenorganisaties, journalisten en burgers, aan bod komen die specifieke betekeniskaders hanteren en uitdragen door (bewust of onbewust) bepaalde aspecten van de werkelijkheid op een bepaalde manier te belichten. De betreffende sociale en politieke groepen dragen op die manier bij aan de productie en reproductie van maatschappelijk dominante referentiekaders. ${ }^{69}$ Deze referentie- of betekeniskaders fungeren als een geheel van overtuigingen en veronderstellingen op grond waarvan bepaalde verschijnselen en ontwikkelingen worden waargenomen en gedefinieerd. Indien een bepaald fenomeen of proces als problematisch wordt geduid, zijn de betekeniskaders eveneens richtinggevend voor de aangedragen oplossingen. ${ }^{70}$

Om de pendel vanuit regionaal sociaal-politiek perspectief te bestuderen, en dus inzicht te verkrijgen in de publieke beeldvorming rond grensarbeid in (Zuid-)Limburg, is gebruik gemaakt van de berichtgeving daarover in regionale dagbladen. Kranten hebben een hoge verschijningsfrequentie, zijn meestal goed bewaard gebleven en bereiken een groot publiek. ${ }^{71}$ Uit onderzoek dat in de tweede helft van de jaren 1980 onder de lezers van Nederlandse dagbladen werd verricht, bleek dat regionale kranten vooral in grensgebieden een aanzienlijk bereik hadden. In Zuid-Limburg vertoonden deze dagbladen een dekkingspercentage van minimaal 66 procent..$^{72}$ In totaal zijn 405 artikelen, opiniestukken en ingezonden brieven over grensarbeid verzameld, die tussen 1957 en 2001 in de twee regionale dagbladen Dagblad De Limburger (en haar voorgangers De Nieuwe Limburger en De Limburger) en Limburgs Dagblad zijn verschenen. ${ }^{73}$ Beide kranten worden veel gelezen. In 2006 las nog ongeveer tweederde van de Limburgse bevolking van dertien jaar en ouder één van beide dagbladen ${ }^{74}$ Hoewel zij sinds 2006 een gezamenlijke redactie hebben, ${ }^{75}$ vertonen de historie, het afzetgebied en het karakter van Dagblad de Limburger en het Limburgs Dagblad enige verschillen.

67 Wester, 'Inhoudsanalyse als onderzoeksontwerp', 12; zie ook Paasi die spreekt van 'material manifestations' van het bewustzijn en handelen van leden van sociale groeperingen (Territories, boundaries and consciousness, 69).

68 Van Vree, 'Massapers en modernisering', 108; Ehlers, 'Tageszeitunge an Maas und Oder', 368.

69 Overigens gebruiken en interpreteren mensen media vanuit hun eigen culturele achtergrond (zie Renckstorf, 'Vormen of spiegelen de media beelden?', 24-28). De verwerking van de berichten door het publiek is hier geen thema van onderzoek. Het gaat er uitsluitend om dat media een indruk geven van de beeldvorming rond de grenspendel in het publieke domein.

70 Dit is geïnspireerd door het concept 'frames', dat de beleidswetenschappers Schön en Rein introduceerden om de constructie van beleidsproblemen te analyseren (Frame Reflection, 23).

71 Zie bijvoorbeeld Strüver, 'Significant Insignificance', 31.

72 Verschuren en Memelink, Media-atlas van Nederland, 32-36.

73 In verband met de leesbaarheid wordt hier nu verder volstaan met het gebruik van de term 'artikelen'. Af en toe boden deze interessante informatie die ook in andere delen van het onderzoek is gebruikt. In appendix B wordt uiteengezet waarom ook artikelen over het jaar 1957 in het onderzoek zijn meegenomen.

74 http://www.limburgadverteren.nl/bereikcijfers/. In 1997 kende het Limburgs Dagblad een oplage van 80.700 en hadden nationale kranten een marktaandeel van slechts 12 procent (Ehlers, 'Tageszeitungen an Maas und Oder, 354-355 (op basis van gegevens van het Centraal Bureau voor Courantenpubliciteit; Helaas presenteert zij geen relatieve cijfers over de regionale dagbladen in Limburg. Zij stelt wel dat zij een bovengemiddeld bereik hebben).

75 http://www.persmediamonitor.nl/cgi-bin/display.cgi?path=1_2. 
Dagblad De Limburger wordt hoofdzakelijk in het westelijk en noordelijk deel van Zuid-Limburg gelezen. De geschiedenis van deze krant begon met de oprichting van het Herlener Wochenblatts in 1845 . Tot het einde van de jaren 186 o verscheen het blad in het Duits. Vanaf 1870 kwam de krant als Limburger Courier, later Limburger Koerier, uit in het Nederlands. In 1901 verhuisde de redactie van Heerlen naar Maastricht. Na de Tweede Wereldoorlog, waarin het blad een pro-Duitse koers voer, werd het onder de naam Gazet van Limburg tijdelijk overgenomen door een verzetsorganisatie. Met ingang van $1955 \mathrm{kwam}$ de krant weer in handen van de oorspronkelijke uitgever en wijzigde de naam in De Nieuwe Limburger, die in 1971 met de Maasen Roerbode fuseerde tot De Limburger. In die tijd benadrukte de redactie het katholieke karakter van het blad. In 1995 ging De Limburger samen met het Dagblad voor Noord-Limburg verder als Dagblad De Limburger. ${ }^{76}$ Onderzoek in de jaren 1990 laat zien dat deze krant relatief weinig aandacht besteedde aan actualiteiten uit de naburige Duitse en Belgische regio's. ${ }^{77}$ Het is niet duidelijk of dat eveneens betrekking heeft op grensarbeid en andere vormen van grensoverschrijdende interactie.

Het Limburgs Dagblad kent met name in oostelijk Zuid-Limburg een groot lezerspubliek..$^{7}$ De krant werd in 1918 in Heerlen opgericht op aandringen van de katholieke kerk en de katholieke arbeidsbeweging. In 1972 nam de niet-katholieke Telegraaf Holding de krant over, wat de krant duizenden abonnees kostte. In vergelijking met Dagblad de Limburger en zijn voorgangers had het Limburgs Dagblad in de eerste helft van de jaren 1990 meer oog voor nieuws uit de aangrenzende gebieden, en dan met name de Regio Aken. ${ }^{79}$ Ook hier is het onduidelijk of dit tevens geldt voor grensarbeid en andere vormen van grensoverschrijdende mobiliteit.

Om de regionale beeldvorming rond grensarbeid(ers) te onderzoeken zijn de krantenartikelen aan een basale kwantitatieve en een intensieve kwalitatieve inhoudsanalyse onderworpen. Het kwantitatieve deel diende om globale trends in kaart te brengen. Het kwalitatieve, interpretatieve, gedeelte maakte het mogelijk de dominante betekenissen die grensarbeid kreeg, te ontleden door ze in hun specifieke ruimtelijke en historische context te plaatsen. De achterliggende referentiekaders met betrekking tot Zuid-Limburg als grensgebied en de grens waren zowel expliciet als impliciet in het materiaal aanwezig. Door de artikelen te contextualiseren zijn zowel de manifeste betekenis als de meer latente vanzelfsprekendheden zo veel mogelijk geëxpliciteerd. ${ }^{\circ 0}$ De exacte uitvoering van het krantenonderzoek wordt besproken in appendix B.

\section{Interviews}

Om de dagelijkse praktijk en betekenis van het werken in Duitsland vanuit het perspectief van de grensarbeiders te onderzoeken, is gebruik gemaakt van retrospectieve diepte-interviews, ook wel oral history genoemd. Deze onderzoeksmethode maakt het mogelijk een structuralistisch beeld van de (recente) geschiedenis aan te vullen met de ervaringen van individuele historische actoren. ${ }^{81}$ Het gebruik van interviewmateriaal sluit aan bij de toegenomen aan-

\footnotetext{
76 Pleijter et al., 'Materiaalselectie en registratie', 49 .

77 Sauerland, Grenzüberschreitende raumbezogene Informationen, 111-117.

78 Ibidem, 113; Ehlers, 'Tageszeitungen an Maas und Oder', 353; Knippenberg en De Pater, De Eenwording van Nederland, 73.

79 Sauerland, Grenzüberschreitende raumbezogene Informationen, 116-121 (op basis van Van Denzen et al., Een bijzonder bedriff in Limburg) .

8o Zie ook Wester, 'Inhoudsanalyse als onderzoeksontwerp', 14, 30, 32. Deze analyse wijkt af van vertooganalyse, omdat daarbij dikwijls veel aandacht uitgaat naar de exacte structuur van de argumentatie in (meestal een kleinere hoeveelheid) media-materiaal (zie Tonkiss, 'Analysing discourse', 250).

81 Zie Lüdtke, 'Introduction'.
} 
dacht voor het actorperspectief in de literatuur over grensarbeid. De historici Baud en Van Schendel achten haar bijzonder geschikt om de ontwikkeling van het handelen en denken van grensbewoners ten aanzien van grenzen te bestuderen. ${ }^{82}$ Het bekendste voorbeeld van oral history in de grensstudies is de eerder aangehaalde studie van de historicus Martínez over de bewoners van het Mexicaans-Amerikaanse grensgebied..$^{3}$

Met behulp van retrospectieve open interviews kan een diepgaand inzicht worden verkregen in de ervaringen van een groep individuen en de historische en ruimtelijke context waarin zij zich heeft bewogen. Het gaat er dus niet om een algemeen representatief beeld te schetsen. Hier zijn interviews met de grensarbeiders gebruikt om zicht te krijgen op de manier waarop praktijken en percepties van grensarbeiders met betrekking tot het werken in Duitsland zich tot de grens verhielden.

In de geschiedwetenschap en de sociologie bestaat er nogal wat discussie over het gebruik van orale bronnen. Enerzijds wordt erop gewezen dat zij slechts subjectieve en contextgebonden informatie opleveren. De herinnering aan en interpretatie van het verleden komen in het heden en via het interviewproces tot stand en zijn mede afhankelijk van de situatie waarin de informant zich bevindt, zijn/haar persoonlijk verleden en het collectieve geheugen. Er is dus nooit sprake van een volledig waarheidsgetrouwe reconstructie van het verleden, maar altijd van constructie en interpretatie. ${ }^{8} 4$ Anderzijds is interviewmateriaal niet uitsluitend een discursieve constructie. Het kan wel degelijk lichtwerpen op dagelijkse praktijken en is dus geen fictie..$^{85}$ Verder wijst de historica Henkes er terecht op dat de afstand tot het verleden ervoor zorgt dat terugblikken behalve vertekenend, ook verhelderend kunnen werken. De distantie biedt immers ruimte voor reflectie vanuit het heden, waardoor schijnbare vanzelfsprekendheden uit het verleden kunnen worden geëxpliciteerd..$^{86}$

Gezien de kanttekeningen die er bij retrospectieve interviews kunnen worden geplaatst, is het net als bij andere bronnen van belang hen kritisch te benaderen. Dat is gebeurd door rekening te houden met de persoon en de geschiedenis van de informant en zijn/haar motieven om mee te werken aan het interview, de temporele context van het interview, het verloop van het interview, of het vertelde verhaal intern consistent was en of het aansloot bij informatie uit andere bronnen, zoals eerder gehouden enquêtes onder grensarbeiders. Uiteraard is er daarnaast gereflecteerd op de positie van de interviewer in het interviewproces. ${ }^{87}$

Gedurende de zomer en het najaar van 2005 zijn er in totaal 26 grensarbeid(st)ers en exgrensarbeid(st)ers geïnterviewd. ${ }^{88} \mathrm{Zij}$ hadden in uiteenlopende tijdvakken en in diverse functies in Duitsland gewerkt. Er zijn in ieder geval personen geïnterviewd met voor bepaalde perioden 'typische' grensarbeiderberoepen, zoals bouwvakkers en metaalarbeiders in de jaren 1960 en 1970 en verpleegkundigen en fysiotherapeuten in de jaren 1990. Voorts is bij de selectie van informanten enige spreiding nagestreefd in de duur van de periode die ze in Duitsland

82 Baud en Van Schendel, 'Toward a Comparative History of Borderlands', 242.

83 Martínez, Border People.

84 Davis en Brinkgreve, 'Inleiding'; voor meer over het gebruik van interviews in de geschiedschrijving: zie Du Bois-Reymond, 'Over de methode van mondelinge geschiedenis' 21-23; Leydesdorff, Wij hebben als mens geleefd, 38, 41-43, 45; Idem, De mensen en de woorden, o.a. 58-64; Yow, Recording oral history. 19-21; Thompson, The voice of the past, 132-133, 157; Kleijer, 'Levensverhalen', $432-434$.

85 Zie ook Davis en Brinkgreve, 'Inleiding', 16-17; Kleijer, 'Levensverhalen', 431-432.

86 Henkes, Heimat in Holland, 19.

87 Zie ook Du Bois-Reymond, 'Over de methode van mondelinge geschiedenis', 24; Leydesdorff, Wij hebben als mens geleefd, 34 ; Idem, De mensen en de woorden, o.a. 97-99; Yow, Recording oral history, 18, Thompson, The voice of the past, 119-120; Davis en Brinkgreve, 'Inleiding', 7. 88 In plaats van telkens apart naar de grensarbeid(st)ers en ex-grensarbeid(st)ers te verwijzen, wordt hier in verband met de leesbaarheid volstaan met 'grensarbeiders'. 
werkten, hun woonplaats, hun geslacht en hun leeftijd. In hoofdstuk 6, waar de interviews centraal staan, is getracht zo veel mogelijk recht te doen aan deze diversiteit, door steeds op eventuele verschillen tussen de informanten te wijzen. Uitgangspunt was dat alle informanten, ondanks hun verscheidenheid, met vergelijkbare omstandigheden zijn geconfronteerd doordat zij in Duitsland hebben gewerkt. De centrale vragen daarbij waren hoe zij hiertoe zijn gekomen, hoe de dagelijkse praktijk van het pendelen er volgens hen uitzag, wat het voor hen betekende om in Duitsland te werken en hoe zij zich tot hun woon- en werkland verhielden. In de analyse is vervolgens aandacht besteed aan de vraag hoe dit alles was verbonden met de grens en of zich hierin verschillen voordeden onder de informanten. Meer informatie over de uitvoering van de interviews en de informanten is te vinden in appendix $\mathrm{C}$.

Nadat in dit hoofdstuk het theoretische kader en de onderzoeksaanpak zijn afgebakend, wordt in het volgende hoofdstuk de casus nader geïntroduceerd. Daarbij wordt ingegaan op de (moeizame) integratie van (Zuid-)Limburg in de Nederlandse staat en de literatuur over grenspendel vanuit (Zuid-)Limburg naar Duitsland. 


\section{Hoofdstuk 3 Zuid-Limburg: tussen en over grenzen}

Dit onderzoek concentreert zich op de grenspendel vanuit Zuid-Limburg naar Duitsland. In de langgerekte en perifeer gelegen provincie Limburg is de grens met het buitenland nooit ver weg en vele malen langer dan de grens met de rest van Nederland. ${ }^{1}$ In de negentiende eeuw werd het gebied ook wel aangeduid als 'vraemd aanhangsel'. ${ }^{2}$ Dat verwees niet alleen naar zijn vorm en excentrieke ligging. De provincie heeft bovendien van meet af aan een bijzondere positie ingenomen binnen de Nederlandse eenheidsstaat. Om die reden werd zij eveneens betiteld als 'een eigenaardig kind in de Nederlandsche familie'. ${ }^{3}$ Hoewel Limburg nog geen twee eeuwen oud is, kent zijn bevolking een sterke regionale identiteit. Hieronder wordt beschreven hoe deze zich ontwikkelde in reactie op de inlijving in de Nederlandse natiestaat. Daarbij is tevens aandacht voor de veranderende relatie met de buurlanden Duitsland en België en de recente trend van denationalisering op bestuurlijk niveau. Aansluitend wordt de literatuur over de grenspendel vanuit (Zuid-)Limburg naar Duitsland sinds de negentiende eeuw behandeld.

\section{'EEN EIGENAARDIG KIND IN DE NEDERLANDSCHE FAMILIE'‘}

De Nederlandse provincie Limburg bestaat pas sinds 1839 in haar huidige vorm. Tot het einde van de achttiende eeuw vormde het gebied een lappendeken van kleinere eenheden die allen onder een ander, soms dubbel, gezag stonden. Zo hoorde Maastricht reeds bij de Republiek der Verenigde Provinciën, terwijl het tegelijkertijd onder de prins-bisschop van Luik viel. Andere gebieden waren in handen van onder meer de hertog van Gulik, de Oostenrijkse keizer en de koning van Pruisen (zie figuur 3.1). ${ }^{5}$

Met de komst van de Fransen (in 1794) in de zuidelijke en de Bataafse revolutie (in 1795) in de noordelijke Nederlanden kwam daar verandering in. In 1795 vormde het gebied dat nagenoeg samenvalt met de hedendaagse Nederlandse en Belgische provincies Limburg voor het eerst een administratieve eenheid, het Departement van de Nedermaas, waarvan Maastricht de hoofdstad was. ${ }^{6} \mathrm{Na}$ het Congres van Wenen in 1815 werd deze eenheid vrijwel gehandhaafd,

\footnotetext{
1 Omdat er in de literatuur doorgaans geen onderscheid wordt gemaakt tussen het noordelijke en zuidelijke deel van de provincie, wordt de gehele provincie Limburg hier als analyse-eenheid genomen.

2 Op den Camp, 'Towards one Nation', 95, op basis van de brochure De Limburgse Kwestie.

3 Geurts en Janssen, 'Ruim een eeuw geschiedoefening', 48 (op basis van de brochure De Limburgse Kwestie), zoals aangehaald in Lemmens, Aan vorst en vaderland gehecht, 119 .

4 Ibidem.

5 Knippenberg, 'The incorporation of Limburg', 39-41.

6 Een aantal gebieden (bijvoorbeeld Sittard en omgeving) hoorde echter bij het Departement van de Roer, waarvan Aken de hoofdstad was (zie Leerssen et al., Historische doorkijk op het MAHL-gebied, 38-39; Knippenberg, 'The incorporation of Limburg', 42).
} 
FIGUUR 3.1 'LIMBURG' 1785-1794

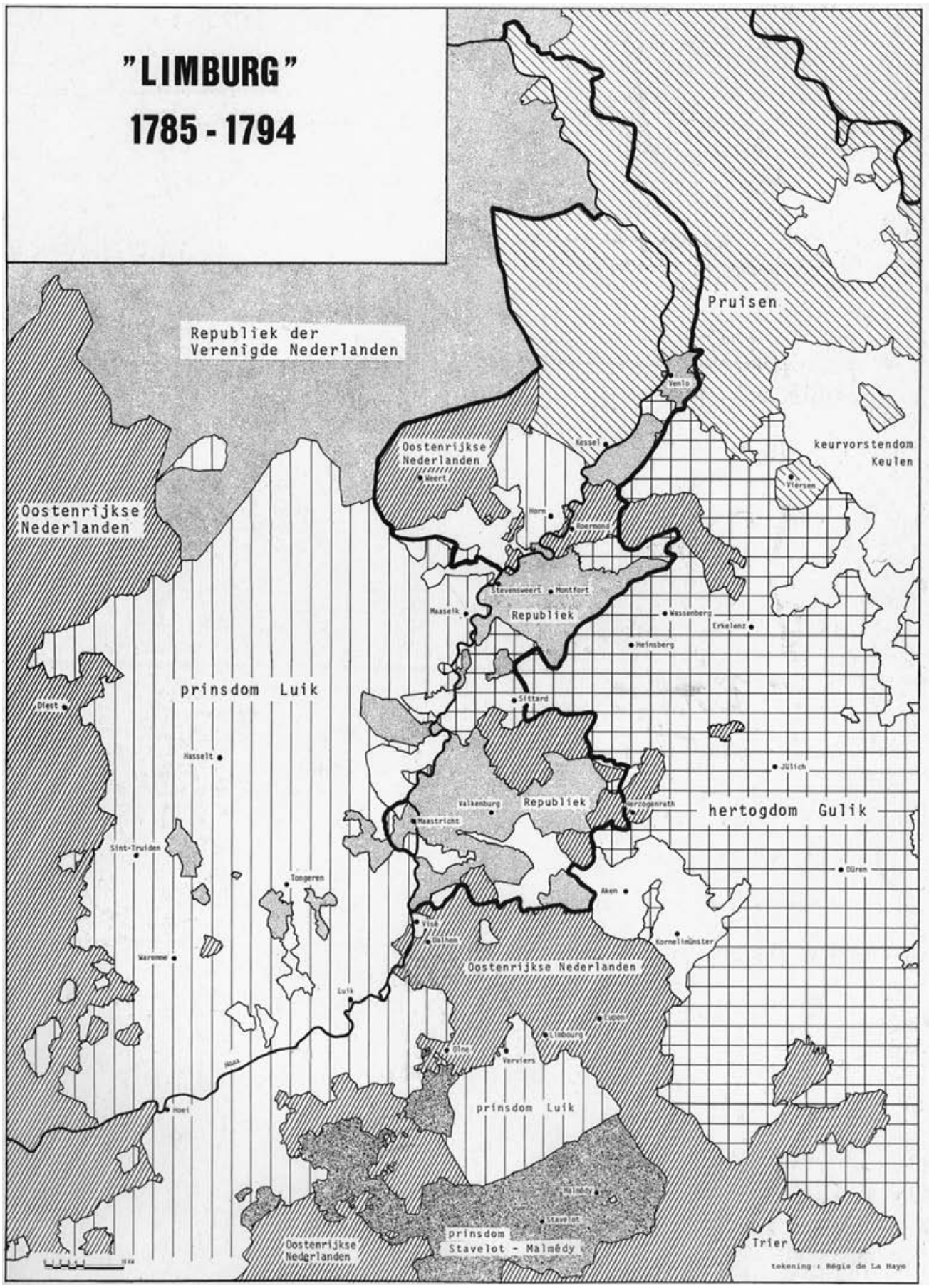

Bron: De la Haye, Limburgse voorouders, 84 . 
zij het onder een ander gezag. Vanaf dat moment maakte het gebied als de provincie Limburg deel uit van het nieuwe Verenigd Koninkrijk der Nederlanden. Tegelijkertijd werd het gescheiden van oostelijker gelegen gebieden die onder Pruisisch gezag kwamen. ${ }^{7}$ De grens tussen de hedendaagse Nederlandse provincie Limburg en Duitsland werd daarmee vastgelegd.

De integratie van de provincie Limburg in de Nederlandse staat verliep stroef. Uit onvrede over het Nederlandse bewind is een aantal pogingen ondernomen om het gebied los te weken uit dit verband. Met het begin van de Belgische Opstand in 1830 trad een onzekere periode aan, waarin vrijwel de gehele provincie onder Belgisch bestuur kwam te vallen. ${ }^{8}$ De bevolking kon zich daar over het algemeen in vinden. Na jaren van internationale onderhandelingen werd in 1839 echter afgesproken dat het oostelijk deel van het toenmalige Limburg, de huidige Nederlandse provincie Limburg dus, opnieuw onder Nederlands gezag zou komen. Voorts werd bepaald dat het als hertogdom lid werd van de Duitse Bond, een samenwerkingsverband van Duitse staten onder leiding van Pruisen en Oostenrijk. ${ }^{9}$ Deze situatie viel lang niet bij iedereen in goede aarde. In de jaren 1840 zochten separatistische bewegingen aansluiting bij respectievelijk België en Duitsland. In noordelijker gelegen delen van Nederland leek hier lang niet altijd bezwaar tegen te bestaan. In deze context werden tevens de kwalificaties 'een vraemd aanhangsel' en 'een eigenaardig kind in de Nederlandsche familie' gebruikt. Uiteindelijk slaagden de afscheidingsbewegingen er niet in hun missie te verwezenlijken. Ze bevorderden echter wel gevoelens van eenheid onder de Limburgers. Daarmee ontwikkelde de provincie een regionaal bewustzijn in de context van het nationaliseringsproces. ${ }^{10}$

Terwijl de grens met Duitsland in het begin niet altijd als legitiem werd ervaren, ontwikkelde zij zich in de tweede helft van de negentiende eeuw tot een scherpere sociaal-culturele scheidslijn. Het lidmaatschap van de Duitse Bond droeg het gevaar in zich dat Limburg betrokken raakte bij conflicten waarin de Duitse Bond was verwikkeld, zoals de PruisischOostenrijkse oorlog in 1866. Deze dreiging wakkerde anti-Pruisische sentimenten aan. Parallel daaraan ontstond er ruimte voor een positievere houding ten opzichte van het neutrale Nederland. De afkeer van Pruisen kreeg een extra impuls toen het Limburg ten tijde van de reorganisatie van de Duitse Bond dreigde te annexeren. In 1867 werd de provincie van haar lidmaatschap van de Duitse Bond ontheven. Sindsdien maakt zij eenduidig deel uit van de Nederlandse staat. Desondanks hield de vrees voor de Pruisische expansiedrift nog enige tijd aan, bijvoorbeeld ten tijde van de Frans-Duitse oorlog van 1870-1871. Gedurende dat conflict was de Limburgse publieke opinie voor het eerst uitgesproken pro-Nederlands. De provinciale elite zette zich af tegen de vermeende Pruisische militaristische, autoritaire aard en het Duitse expansionisme. Tegelijkertijd wees zij op 'Nederlandse' deugden, zoals vrijheid, verdraagzaamheid, vredelievendheid en burgerzin. ${ }^{11}$

Hoewel de afkeer van Pruisen een toenadering tot Nederland in de hand werkte, bleef de nationalisering van de provincie een 'zaak van lange adem' ${ }^{12}$ Zo werd in het meest oostelijke

7 Leerssen et al. Historische doorkijk op het MAHL-gebied, 41; Smit, 'Sociaal-culturele problemen', 110-111; Knippenberg, 'The incorporation of Limburg', 39-42. Een aantal gebieden dat eerder bij het Departement van de Roer hoorde (zoals Sittard en omgeving) ging nu ook deel uitmaken van de provincie Limburg.

8 Maastricht en omgeving bleven echter onder Nederlands gezag.

9 Met uitzondering van de steden Venlo en Maastricht.

10 Op den Camp, 'Towards One Nation', 84-85, 95; Knippenberg, 'The incorporation of Limburg', 44-48; Lemmens, Aan Vorst en Vaderland gehecht, 42-43, 120-124, 127; zie ook Orbons en Spronck, 'Limburgers worden Nederlanders'. Ook België werd minder aantrekkelijk doordat het door Frankrijk ingelijfd dreigde te worden (Lemmens, Aan Vorst en Vaderland gehecht , 127).

11 Op den Camp, 'Noch Fransch, noch Pruissisch, maar Nederlandsch!', 85-86, 95-97.

12 Knippenberg en De Pater, De eenwording van Nederland, 27. 
deel van Zuid-Limburg nog tot het begin van de twintigste eeuw veel Duits gesproken. Ook lokale dialecten hielden stand. ${ }^{13}$ Toch groeide de verbondenheid met Nederland. Daarbij was een belangrijke rol weggelegd voor het moderniseringsproces dat zich manifesteerde in processen van sociaal-ruimtelijke integratie en schaalvergroting, zoals de aanleg van nationale transport- en communicatienetwerken, de verzuiling, de introductie van het Nederlandse onderwijs en de opkomst van de (deels door de staat geleide) mijnindustrie. Met de komst van de mijnbouw in Zuid-Limburg maakte de regionale sociale structuur een drastische verandering door en trok het gebied talloze migranten uit binnen- en buitenland aan. ${ }^{14}$

Naast het moderniseringsproces waren de twee wereldoorlogen van onmiskenbaar belang voor de integratie van Limburg in de Nederlandse eenheidsstaat. Tijdens de Eerste Wereldoorlog bleef Nederland in tegenstelling tot België en Duitsland neutraal. Zo bleven de Limburgers veel verschrikkingen bespaard, wat ervoor zorgde dat zij zich meer met Nederland gingen vereenzelvigen. Ook de afsluiting van de landsgrens droeg bij aan de toenemende nationale oriëntatie. Deze verhinderde bovendien de toevoer van kolen uit het buitenland, waardoor de betekenis van de Limburgse steenkolenmijnen voor de nationale economie toenam, en zij een explosieve groei doormaakten. Door de versterkte identificatie met Nederland riepen Belgische inlijvingspogingen aan het einde van de Eerste Wereldoorlog veel weerstand op. Gedurende de Tweede Wereldoorlog hadden Limburg en de rest van Nederland voor het eerst een gemeenschappelijke vijand: de Duitsers. Daardoor werden Nederlands-Duitse wijzijtegenstellingen verscherpt. ${ }^{15}$

In 1949 werd de Bondsrepubliek Duitsland opgericht en werden enkele 'grenscorrecties' doorgevoerd. Zo kreeg Nederland onder andere de nabij Sittard gelegen Duitse gemeente Selfkant toegewezen. In 1963 werden deze grensverschuivingen weer ongedaan gemaakt. ${ }^{16}$ In de naoorlogse periode raakte de Limburgse bevolking verder geïntegreerd in de Nederlandse natiestaat. Dat hing samen met de uitbouw van de welvaartsstaat, het stijgende opleidingsniveau, de verbreiding van nieuwe nationale massamedia, het door de Nederlandse regering gevoerde herstructureringsbeleid rond de mijnsluitingen en de groeiende (veelal nationaal begrensde) geografische mobiliteit. ${ }^{17}$ Tijdens de economische crisis van de jaren 1980 besloot de Nederlandse regering de verzorgingsarrangementen te herzien. Daarbij borduurde zij echter voort op het bestaande nationale systeem en trachtte ze de bestaande arrangementen te handhaven, ${ }^{18}$ waardoor de (Limburgse) bevolking niet minder aan de Nederlandse staat gebonden raakte.

In Nederlandse grensgebieden, waaronder Limburg, zou de beeldvorming rond Duitsland en de Duitsers afwijken van die in andere delen van het land. Op de vraag in welke richting bestaat evenwel geen eenduidig antwoord. ${ }^{19}$ Wat Limburg betreft stellen sommigen dat de bevolking een grote verwantschap vertoont met de aangrenzende Belgische en Duitse gebieden, en dat zij daar van oudsher intensieve contacten mee onderhoudt. ${ }^{20}$ Toch is uit onderzoek in

13 Goossens, 'De evolutie van het taalgebruik', 214-220.

14 Knippenberg en De Pater, De eenwording van Nederland; specifiek over Limburg zie Knippenberg, 'The incorporation of Limburg', 49-55.

15 Van der Heijden, 'Tijden veranderen', 103-104; Knippenberg, 'The incorporation of Limburg', 55-56; Abbenhuis, 'Where War Met Peace', 63.

16 Leerssen et al. Historische doorkijk op het MAHL-gebied, 51; Smit, Sociaal-culturele problemen', 111.

17 Knippenberg, 'The incorporation of Limburg', 58-59; Van Vliet, 'Sociale zekerheid in de klem', 96.

18 Van der Veen en Trommel, 'Maatschappelijke verandering en de verzorgingsstaat', 308-309.

19 Renckstorf en Lange, Niederländer über Deutsche, 35; Müller, 'Stille Tage im Klischee', 22-26; Wielenga, Van vijand tot bondgenoot, 312; Smit, 'Sociaal-culturele problemen', 114.

20 Zie Jansen 'Wisselende banden in een grensregio'. 
de jaren 1990 gebleken dat veel van de in Nederland circulerende stereotypen over Duitsers ook in Zuid-Limburg de ronde deden. ${ }^{21}$

Hoe het ook zij, (Zuid-)Limburg is altijd een typisch grensgebied gebleven, dat een ambigue relatie onderhoudt met het land waar het deel van uitmaakt. De provincie is weliswaar geintegreerd in de Nederlandse staat, maar Limburgers beschouwen zichzelf als afwijkend van de rest van de bevolking en worden eveneens als zodanig gezien. Zij zetten zich vooral af tegen het nationale centrum, dat ze 'Holland' noemen. ${ }^{22}$ Zoals gezegd liggen de wortels van deze regionale identificatie in de eerste helft van de negentiende eeuw, toen de huidige provincie Limburg ontstond, het gebied deel werd van de Nederlandse staat, en diverse afscheidingsbewegingen daar een einde aan probeerden te maken. Het Limburgse particularisme was destijds nauw verbonden met de katholieke religie en gevoelens van achterstelling ten opzichte van de rest van het land. ${ }^{23}$ Aan het einde van de twintigste eeuw ontleenden Limburgers hun gevoelens van eigenheid volgens de etnologe Wijers vooral aan de lokale dialecten, de katholieke achtergrond en de als anders ervaren mentaliteit. Zo werden 'Hollanders' omschreven als nuchter, bedachtzaam en zuinig en werd er tegelijkertijd een contrasterend beeld van de Limburgers geschapen als gemoedelijke, ongedwongen levensgenieters. ${ }^{24}$

Sinds het midden van de jaren 1970 is er een nieuwe tendens waarneembaar, althans onder de bestuurlijke elite. Vanaf 1976 maakt Zuid-Limburg deel uit van de Euregio Maas-Rijn (EMR). In dit samenwerkingsverband participeren overheden en andere organisaties uit ZuidLimburg, de Duitse Regio Aken en de Belgische provincies Luik en Limburg en de Duitstalige Gemeenschap. Zij proberen grensoverschrijdende interactie te stimuleren door barrières verbonden met de aanwezigheid van de landsgrenzen te verlagen en de nadelen van de nationaal gezien perifere ligging van de deelgebieden op te heffen. De EMR is vooral actief sinds 1991 toen zij een wettelijke status kreeg en Europese INTERREG-subsidies ging ontvangen. Net als andere Euregio's presenteert zij zichzelf als 'laboratorium van Europese integratie', de plaats waar Europa 'concreet' moet worden. ${ }^{25}$ De EMR typeert grenzen in dit verband als 'littekens van de geschiedenis' ${ }^{2}{ }^{26} \mathrm{Zij}$ zijn het resultaat van processen van staats- en natievorming die volgens haar een einde maakten aan een historische 'oersituatie' van eenheid. Daarbij wordt doorgaans gerefereerd aan de Karolingische tijd. ${ }^{27}$

Net als in andere Euregio's is de samenwerking in de EMR niet zonder problemen en vindt het grensoverschrijdend regionalisme onvoldoende aansluiting bij de lokale bevolking. Alhoewel de Euregionale grenzen sinds 1993 fysiek gezien zijn geopend, blijkt de interregiona-

21 Van Beek, Samenwerking?, 85-89.

22 Knippenberg, 'The incorporation of Limburg', 58; Wijers, 'In één hand de rozenkrans', 117-122.

23 Orbons en Spronck, 'Limburgers worden Nederlanders', 40-48; Van der Heijden, 'Tijden veranderen' $103-104$.

24 Wijers, 'In één hand de rozenkrans', 113, 117-122, 128-129. Overigens hebben de regionale identiteiten van Nederlands en Belgisch Limburg zich als gevolg van de afwijkende positie in en processen van staatsvorming in Nederland en België anders ontwikkeld, bijvoorbeeld met betrekking tot het belang dat er aan de regionale dialecten werd gehecht (Nissen, 'De ontplooiing van het regionaal zelfbewustzijn').

25 Zie Stichting Euregio Maas-Rijn, Europa Concreet

http://www.euregio-mr.org/emr_site/pdf/Europa_konkret_1005.pdf; zie ook Martiniello en Massart, L'Euregio Meuse-Rhin, 258; Knippenberg, 'The Maas-Rhine Euroregion', 6o8-6o9.

26 www.euregio-mr.org/N/NS/N32/N323.htm (22-7-2003). Het idee van grenzen als littekens van de geschiedenis is in 1973 gelanceerd door Alfred Mozer, die betrokken was bij de oprichting van de eerste Euregio in de omgeving van Enschede en Gronau, maar hij paste het ook toe op andere grensgebieden (zie Mozer, Euregio, 3; Idem, 'Entwicklungspolitik zu hause', 14).

27 Knotter, 'Paradoxen van de grens', 173; Müller, 'Het zogenaamde Frankenland', 53-54; Knippenberg, 'The Maas-Rhine Euroregion', 610, 612; Knotter, 'Na de Kulturraumforschung', 243-246; zie ook Stichting Euregio Maas-Rijn, Europa Concreet, waarin met behulp van een tijdbalk op het gemeenschappelijk verleden wordt geattendeerd (http://www.euregio-mr.org/emr_site/pdf/Europa_konkret_ 1005.pdf). 
le samenwerking bovendien niet of nauwelijks te leiden tot meer grensoverschrijdende mobiliteit. In die zin lijken de grenzen niet aan betekenis te hebben ingeboet. ${ }^{28}$ Toch vormt de Euregionale samenwerking een breuk met het verleden, omdat zij impliceert dat de bestuurlijke elite nationale kaders loslaat. In hoofdstuk 5 zal blijken dat dit samenging met een veranderende evaluatie van de grenspendel naar Duitsland.

\section{VAN BRIKKENBAKKERS TOT BOUWVAKKERS}

De geschiedenis van de uitwisseling van arbeidskrachten tussen (Zuid-)Limburg en Duitsland is te omschrijven als een pendelbeweging. Op het ene moment werd er in groten getale vanuit Zuid-Limburg in Duitsland gewerkt. Op het andere moment was de verhouding omgekeerd. Uit onderzoek van de historicus Korres is gebleken dat er sinds de stichting van de huidige provincie Limburg in 1839 tot de Eerste Wereldoorlog op grote schaal vanuit Zuid-Limburg in Duitsland werd gewerkt. ${ }^{29}$ In deze periode was de grens nog erg poreus en trokken er talloze arbeidskrachten, veelal als trek- of seizoenarbeiders, naar het Ruhrgebied. Zij vonden onder meer emplooi als 'brikkenbakker', oftewel steenbakker, en landarbeider. Vanwege het afnemend treinverkeer en de invoering van een systeem van 'arbeiderspassen' werd het in de Eerste Wereldoorlog moeilijker om in Duitsland te werken. De koersdaling van de Duitse mark in de jaren 1920 maakte het eveneens minder aantrekkelijk. Onder die omstandigheden nam het aantal Duitslandgangers af. ${ }^{30}$ Tijdens het interbellum draaide de migratierichting om. Als gevolg van de snelle ontwikkeling van de Nederlandse mijnbouw en de gelijktijdige economische problemen in Duitsland, kwamen er tegelijkertijd duizenden Duitsers in Zuid-Limburg werken. Tijdens de crisis van de jaren 1930 verloren zij hun werk en keerden ze terug naar hun land van herkomst. ${ }^{31}$ Korres heeft geen onderzoek verricht naar de arbeidsmobiliteit ten tijde van de Tweede Wereldoorlog. De historica Van Son is nagegaan in hoeverre Limburgers in deze periode uit vrije wil in Duitsland werkten. Tot 1942 konden Nederlandse werklozen, onder de dreiging dat hun uitkering zou worden ingetrokken, 'vrijwillig' in Duitsland gaan werken. Nadien nam de druk om een baan in Duitsland te accepteren toe. Vergeleken met de rest van Nederland waren er vóór de invoering van de verplichte tewerkstelling al heel wat Limburgers werkzaam in het Duitse grensgebied. Van Son verklaart dit uit de nabijheid van Duitsland, de beperktere taalbarrière en de relatief grote werkloosheid in Limburg, waardoor de hogere Duitse lonen op hen een grotere aantrekkingskracht uitoefenden dan op andere Nederlanders. Met ingang van 1942 moest tevens werk in andere delen van Duitsland worden aangenomen, en werd het werken in het naburige deel van Duitsland een alternatief voor tewerkstelling op grotere afstand. Toch nam in deze periode het aantal Limburgers dat dieper in Duitsland werkte sterk toe in verhouding tot de grensarbeiders. ${ }^{32}$ Met betrekking tot de na-

\footnotetext{
28 Van Beek, Samenwerking?, 78-100; Martiniello en Massart, 'L'Eurégio Meuse-Rhin', o.a. 266-267; Italiano, 'Mobilité et attractivité au sein de l'Eurégio', 68-82; Kramsch, 'Re-imagining the 'Scalar Fix”, 226; Knippenberg, 'The Maas-Rhine Euroregion', 621.

29 Korres, 'Arbeitmigration in der Euregio Maas-Rhein; Idem, 'Historische interacties in de Euregio Maas-Rijn'.

30 Voor een gedetailleerdere beschrijving van de grensoverschrijdende arbeidsmobiliteit in deze periode, zie Langeweg, 'Werken over de grens'; zie ook Simons, 'Belgische en Nederlandse grensarbeiders', 243-246.

31 In deze periode werkten er ook veel Joegoslaven, Polen en Italianen in de Nederlandse mijnen.

32 Van Son, 'Between tradition and coercion', 502-503, 507; zie ook Müller, 'Dwangarbeid aan de grens'; overigens vond Korres dat 18 procent van de mijnwerkers bij de Eschweiler Bergwerks Verein (een mijnbedrijf dat in het Duitse grensgebied zetelde) tussen 1939 en 1945 Nederlands was, waarvan tweederde uit Zuid-Limburg afkomstig was. Na 1945 bezetten de Nederlanders nog maar 1,5 procent van de arbeidsplaatsen bij dit bedrijf (Korres, 'Arbeitsmigration in der Euregio Maas-Rhein', 55-56).
} 
oorlogse periode constateert Korres dat er in de jaren 1960, mede onder invloed van de sluiting van de Limburgse mijnen, een groeiend aantal Zuid-Limburgers in de Duitse metaal- en bouwsector werkte. ${ }^{33}$ Dankzij de verruimde vervoersmogelijkheden ging het nu hoofdzakelijk om grensarbeiders, die dagelijks dan wel wekelijks naar huis terugkeerden. ${ }^{34}$

Op basis van zijn studie naar de interregionale uitwisseling van arbeidskrachten in de negentiende en twintigste eeuw concludeert Korres dat de arbeidsmigratie in de huidige EMR sterker door de conjunctuur dan door politieke ontwikkelingen werd bepaald. Nationale grenzen zouden 'slechts een zeer geringe tot geen enkele belemmering' hebben gevormd voor de arbeidsmobiliteit. In bedrijfstakken als de mijnbouw kon er volgens Korres zelfs van een grensoverschrijdende arbeidsmarkt worden gesproken. Daarnaast stelt hij dat de arbeidsmigratie tot de Tweede Wereldoorlog grotendeels werd gedreven door overlevingskansen, maar dat in de periode daarna het profiteren van loonverschillen voorop stond. ${ }^{35}$ Hij lijkt de grens echter primair als een politiek-materiële scheidslijn te benaderen, terwijl zij, zoals we in de vorige paragraaf zagen, in de betreffende periode ook een sociaal-culturele dimensie kreeg. Ook werkt hij de ontwikkeling van de pendel na de Tweede Wereldoorlog niet verder uit.

Over de naoorlogse periode zijn er diverse andere, vaak economische, studies verricht die doorgaans een kwantitatieve korte termijn- of momentopname van de grenspendel vanuit (Zuid-)Limburg naar Duitsland behelzen..$^{36}$ In opdracht van de Nederlandse regering onderzocht het Nederlands Economisch Instituut (NEI) in het begin van de jaren 1970 bijvoorbeeld de destijds omvangrijke Limburgse Duitslandpendel. Het kwam daarbij tot de conclusie dat er een grensoverschrijdende arbeidsmarkt was ontstaan. In tegenstelling tot Korres zag het NEI dit als een nieuwe situatie, die het gevolg was van processen van schaalvergroting. ${ }^{37}$

Twintig jaar later lagen de kaarten anders. In de jaren 1990 was het aantal grensarbeiders binnen de gehele EMR minimaal. De economen Van Dam en De Grip constateerden mede op basis daarvan dat er geen sprake was van een Euregionale arbeidsmarkt. De grenspendel werd in hun ogen belemmerd door grote verschillen in nationale fiscale, sociale en onderwijssystemen, en het gebrek aan Euregionale arbeidsmarktinformatie..$^{8}$ Om grensoverschrijdende arbeidsmobiliteit te faciliteren en stimuleren werd de EMR in 1992 aangewezen als 'proeftuin' voor het Eures-programma. In diverse arbeidsbureaus werden zogenaamde Eures-loketten geopend waar werkzoekenden en werkgevers terechtkonden voor informatie over grensoverschrijdend werken of voor grensoverschrijdende arbeidsbemiddeling. ${ }^{39}$ In het midden van de jaren 1990 bleken deze loketten echter nog weinig bekendheid te genieten onder werkgevers. ${ }^{4}$

Hoewel de (grotendeels uit Zuid-Limburgers bestaande) Nederlandse pendelstroom naar Duitsland in de jaren 1990 veel kleiner was dan in de jaren 1970, nam hij Europees gezien op

33 Vanaf het einde van de jaren 1940 tot het begin van de jaren 1950 werkten er ook nog vele honderden Limburgers in de Belgische mijnen (Rutten, 'Werken over de grens') en bijvoorbeeld de Belgische textielindustrie (Simons, 'Belgische en Nederlandse grensarbeiders', 375-386).

34 Korres, 'Arbeitmigration in der Euregio Maas-Rhein, 38; Idem, 'Historische interacties in de Euregio Maas-Rijn', 12.

35 Korres, 'Arbeitsmigration in der Euregio Maas-Rhein, 6o-61; Idem, 'Historische interacties in de Euregio Maas-Rijn', 25 -26.

36 Bijvoorbeeld Derks, Pendel 1973-1979; Idem, Limburgse pendel 1977-1985; Wolters et al., Arbeid in beweging; Van Goethem en Dou-

men, Grensarbeid in de Euregio Maas-Rijn; Creemers, Grensoverschrijdende migratie en pendel; Soutif, 'Domicile-Travail'; Van Camp et al., Naar de arbeidsmarkt zonder grenzen.

37 Van den Berg et al., De grenspendel in Limburg, 134-135; Hendriks et al., De gevolgen van de pendel op Duitsland, 29; zie ook Vreuls, 'Grenzüberschreitende Pendlerwanderungen', 12.

38 Van Dam en De Grip, De Euregionale arbeidsmarkt, 7-28.

39 Knippenberg, 'The Maas-Rhine Euroregion', 617.

40 Van Goethem en Doumen, Grensarbeid in de Euregio Maas-Rijn, 104-113; 118-133. 


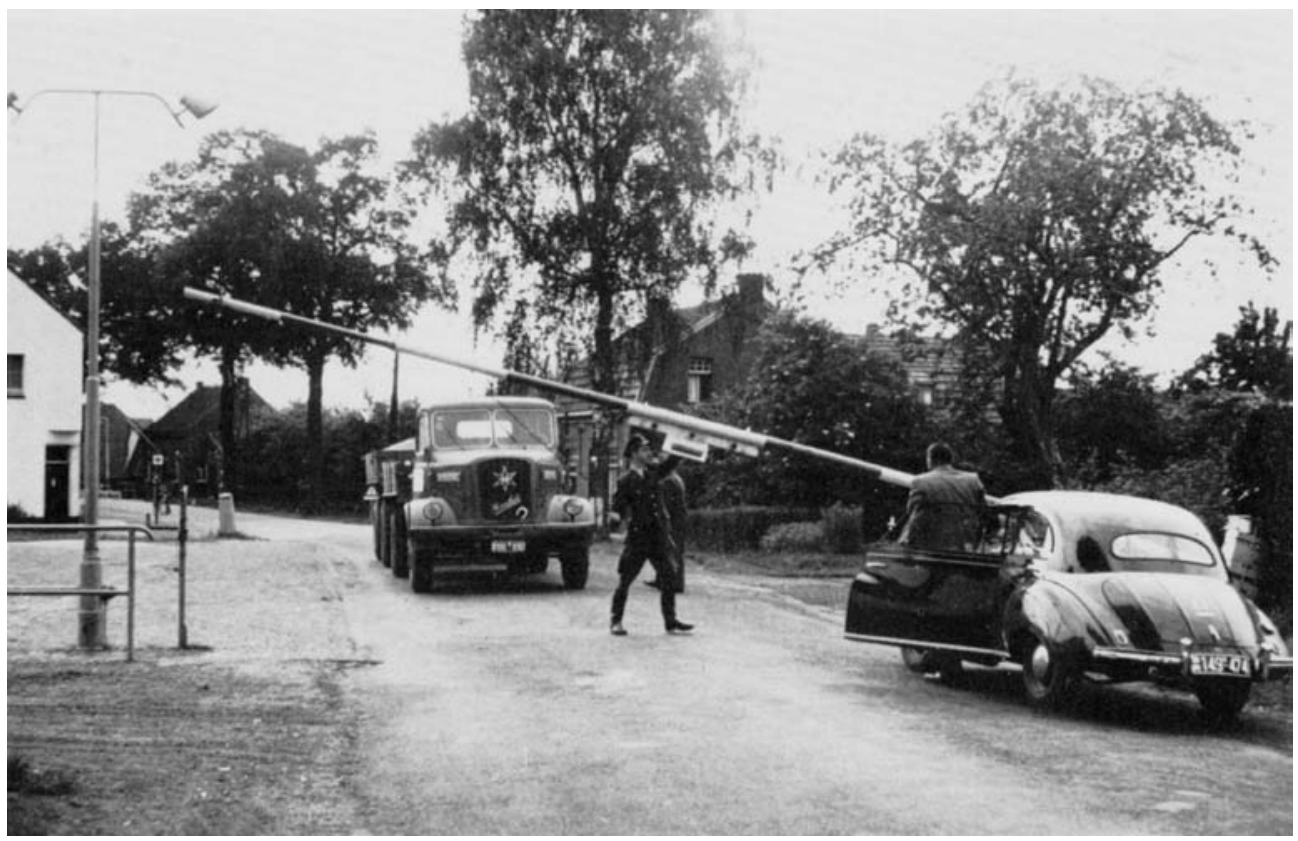

Grensverkeer bij Posterholt. Bron: Erdkamp et al., Roerstreek in oude prenten, 407 (foto niet gedateerd).

beide momenten qua omvang een vijfde positie in. Hij werd onder meer voorgegaan door de pendel vanuit Frankrijk naar Zwitserland en Duitsland..$^{41}$ Verder bleken in de eerste helft van de jaren 1990 binnen de EMR de meeste grensarbeiders vanuit Zuid-Limburg naar Duitsland te pendelen. ${ }^{42}$

De ontwikkeling van de Duitslandpendel vanuit Zuid-Limburg in de periode vanaf 1958 tot en met 2001 is nooit eerder als geheel onder de loep genomen, terwijl dit in het licht van het Europese integratieproces toch een buitengewoon interessant tijdvak is. De geografe Soutif bestudeerde de globale ontwikkeling van de pendelstromen in de EMR tussen 1965 en 1995 . Op basis daarvan stelt zij vast dat het aantal grensarbeiders in de EMR, en meer specifiek vanuit Zuid-Limburg naar Duitsland, sinds 1973 is afgenomen. ${ }^{43}$ Bovendien concludeert ze dat de grens als afbakening van twee systemen van nationale wet- en regelgeving de pendel verhinderde. Omdat zij niet alleen grenspendel in de EMR, maar ook in andere Europese grensgebieden in vogelvlucht bestudeert, presenteert ze weinig specifieke gegevens over de pendel vanuit Zuid-Limburg naar Duitsland. ${ }^{44}$ Voorts besteedt ze niet of nauwelijks aandacht aan de ontwikkeling van de omvang van de grenspendel ten opzichte van de beroepsbevolking en de samenstelling van de pendelstromen, terwijl dit onontbeerlijk is om de ontwikkeling en het regionale belang daarvan te kunnen duiden. ${ }^{45}$ Om een exacter beeld te krijgen wordt de pendelstroom vanuit Zuid-Limburg naar Duitsland in deze studie nauwgezet gevolgd over een

\footnotetext{
41 Ricq, Les travailleurs frontaliers en Europe, 66-67, 80; Soutif, L'intégration européenne, 173, 361

42 Wolters et al., Arbeid in beweging, 176-179.

$43 \mathrm{Zij}$ spreekt van een 'destructurerende pendelstroom', die sterk is afgenomen en waarop grensgebonden institutionele belemmeringen een grote invloed uitoefenen (Soutif, L'intégration européenne, 40-41, 167-183).

44 Het betreft vaak cijfers met betrekking tot de totale grenspendel vanuit Zuid-Limburg (zowel naar Duitsland als naar België) of de totale grenspendel naar de Regio Aken (zowel afkomstig uit Nederland als uit België).

45 Soutif, 'Domicile-travail', 116-127; Idem, L'intégration européenne, 169-183.
} 
langere periode en afgezet tegen sociaal-economische ontwikkelingen aan weerszijden van de grens.

Naast de lange termijnontwikkeling van de pendelstroom vanuit Zuid-Limburg naar Duitsland, is ook de betekenis van de Duitslandpendel op regionaal en individueel niveau tot dusver grotendeels buiten beeld gebleven. In diverse enquêtes is wel enige aandacht besteed aan de ervaringen van de grenspendelaars. Het NEI enquêteerde in 1972 bijvoorbeeld een groep van 647 Limburgse grensarbeiders over onder meer de redenen om in Duitsland te gaan werken, hun informatiekanalen en de werksituatie. ${ }^{46}$ Andere enquêtes leverden gezien de veel kleinere steekproeven geen representatieve informatie op. Zij geven wel aanwijzingen over de ervaringen van de grensarbeiders. In 1980 hield de geograaf Vreuls een enquête onder 64 Nederlandse mannelijke grensarbeiders uit de Oostelijke Mijnstreek. ${ }^{47}$ Vijftien jaar later ondervroeg de geografe Soutif nog 32 grensarbeiders die in het Nederlands deel van de EMR woonden. Helaas is het niet duidelijk of zij in Duitsland dan wel België werkten..$^{8}$

De enquêtes geven een indruk van de totstandkoming en de praktijk van het werken in Duitsland door de jaren heen. Maar ze zeggen weinig over de betekenis die het werk in Duitsland nu precies had voor de grensarbeiders, laat staan voor hun omgeving, en hoe zich dit tot de grens verhield. Deze studie levert een bijdrage aan het opvullen van deze leemten.

$\mathrm{Nu}$ duidelijk is op welk toneel dit onderzoek zich beweegt, kan de stap naar de empirie worden gezet. Daarbij wordt in hoofdstuk 4 ingegaan op de kwantitatieve ontwikkeling van de pendelstroom vanuit Zuid-Limburg naar Duitsland, die tevens een context biedt voor de daaropvolgende kwalitatief getinte hoofdstukken.

\footnotetext{
4681 procent van de respondenten woonde in Zuid-Limburg (Van den Berg et al., De grenspendel in Limburg, 76-119; Hendriks et al., De gevolgen van de pendel op Duitsland, Annex D). Ook is er in 1969 in het kader van een afstudeeronderzoek een enquête afgenomen onder 75 Nederlandse grensarbeiders die in en rond Aken werkten. Deze scriptie lijkt echter geschreven vanuit een zeker wensdenken over de grensregio als oude eenheid, die door nationale grenzen is doorsneden (Kronenwerth, Die Sozialstruktur eines Grenzraums, o.a. 27-32, 161-162, 175-176). Aangezien de enquête van het NEI ongeveer in dezelfde periode is afgenomen, het een gerenommeerd instituut is en, belangrijker nog, een representatievere steekproef betrof, is daar de voorkeur aan gegeven.

47 Verder ondervroeg hij 26 uit Duitsland afkomstige en in Zuid-Limburg woonachtige Duitslandpendelaars (Vreuls, 'Grenzüberschreitende Pendlerwanderungen', 6-11).

48 Soutif, 'Domicile-travail?', 127-143; Idem, L'intégration européenne, 175-180.
} 


\section{Hoofdstuk 4 \\ Wat grensbewoners beweegt De Duitslandpendel in regionaal sociaal-economisch perspectief* $^{\star}$}

Zoals we in hoofdstuk 3 zagen, was de grenspendel vanuit Zuid-Limburg naar het aangrenzende Duitse gebied in de jaren 1990 minimaal. Deze immobiliteit wordt grotendeels toegeschreven aan institutionele discrepanties aan weerszijden van de grens en een gebrek aan arbeidsmarktinformatie. Enkele decennia daarvoor werd er juist op grote schaal in Duitsland gewerkt en zou de grens volgens de historicus Korres en het Nederlands Economisch Instituut (NEI) geen obstakel hebben gevormd. ${ }^{1}$ Hoe kon de situatie in korte tijd zo omslaan? Waardoor kwamen er, ondanks Europese maatregelen om de grensoverschrijdende arbeidsmobiliteit te faciliteren, door de jaren heen minder Zuid-Limburgers in beweging?

Dit hoofdstuk analyseert de kwantitatieve ontwikkeling van de grenspendel vanuit ZuidLimburg naar Duitsland in de periode tussen 1958 en 2002. Daarbij wordt aandacht besteed aan de ontwikkeling van de absolute en relatieve omvang van de pendelstroom en zijn samenstelling naar bedrijfstak of beroepsgroep, geslacht, leeftijd en woon- en werkplaats. Daarnaast wordt de manier waarop deze pendelstroom zich verhield tot de grens met name als politiek-materiële, maar ook als sociaal-culturele scheidslijn, onder de loep genomen. Dat gebeurt door hem af te zetten tegen sociaal-economische ontwikkelingen aan weerszijden van de grens, ${ }^{2}$ en tegen de grootte van de binnenlandse pendelstromen. ${ }^{3}$ Uit deze analyse zal blijken dat de omvang evenals de structuur van de Duitslandpendel drastisch wijzigde, en dat de relatie met de grens op veranderende wijze cruciaal was.

\section{DE ONTWIKKELING VAN DE PENDELSTROOM NAAR DUITSLAND}

In het eerste decennium na de Tweede Wereldoorlog was het aantal Duitslandgangers bijzonder klein. Er werkten meer Zuid-Limburgers in België, vooral in de mijnen en (in mindere mate) in de metaal- en de bouwnijverheid, dan in Duitsland. Volgens het Districtsbureau voor de Arbeidsvoorziening in de Provincie Limburg (DBA) forensden er in 1959 maar zo'n 1.300

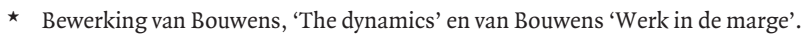

1 Van den Berg et al., De grenspendel in Limburg, 134-135; Hendriks et al., De gevolgen van de pendel op Duitsland, 29; Korres, 'Arbeitsmigration in der Euregio Maas-Rhein, 6o-61; Idem, 'Historische interacties in de Euregio Maas-Rijn', 25-26.

2 Bij de beschrijving van de sociaal-economische ontwikkelingen aan de Duitse zijde van de grens ligt het accent op de ontwikkeling van de arbeidsmarkt in de huidige Regio Aken, omdat dit de belangrijkste bestemming van de grensarbeiders was. Aangezien er ook grensarbeiders in andere delen van met name de deelstaat Noordrijn-Westfalen werkten, zal er daarnaast ook af en toe naar de ontwikkeling daarvan of van de hele deelstaat worden verwezen.

3 Ook andere auteurs wijzen op of gebruiken een vergelijking met de binnenlandse pendel om een indruk te krijgen van de manier waarop de omvang van de grenspendel zich tot de grens verhoudt (Janssen en De Gijsel, 'Do Dutch-German Euregional labour markets really exist?', 3, 8-9; Van Camp et al., Naar de arbeidsmarkt zonder grenzen, 97).
} 


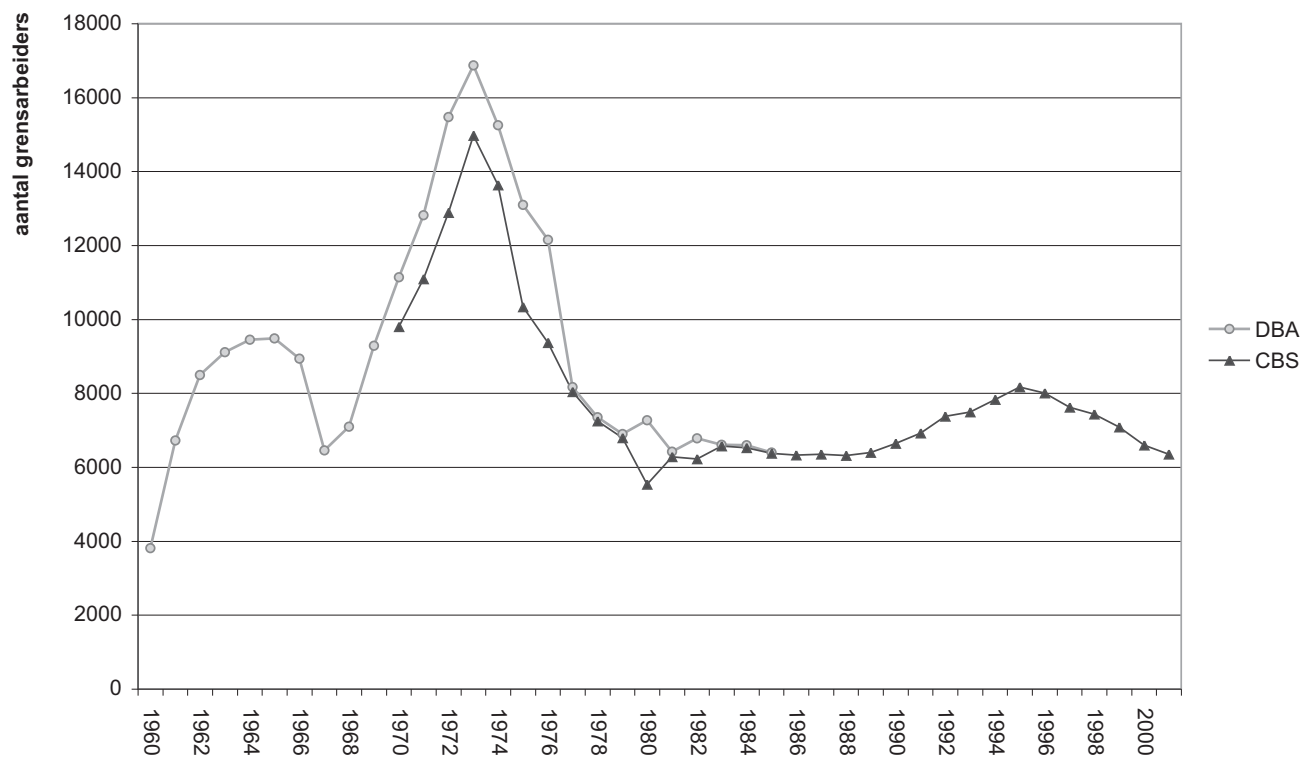

Zuid-Limburgse mannen naar Duitsland, tegen bijna 2.400 naar België. ${ }^{5}$ Een jaar later kantelden de verhoudingen. De omvang van de pendelstroom naar Duitsland ging die naar België overtreffen: bijna 3.400 mannen en ongeveer 450 vrouwen werkten in Duitsland, tegen ruim 2.200 mannen en om en nabij de 200 vrouwen in België. ${ }^{6}$ In de jaren daarna nam dit verschil snel toe.

Figuur 4.1 toont de ontwikkeling van het totale aantal grensarbeiders vanuit Zuid-Limburg naar Duitsland vanaf 1960 tot en met 2001. ${ }^{7}$ Er voltrokken zich geen trendbreuken op de momenten waarop Europese mijlpalen in het kader van het vrij verkeer van werknemers werden bereikt, zoals de effectuering van verordening 1612/68 in 1970, de implementatie van verordening 1408/71 in 1972 en de totstandkoming van de Europese eenheidsmarkt in $1993 .{ }^{8}$ Klaarblijkelijk waren deze niet van grote invloed op de kwantitatieve ontwikkeling van de pendelstroom.

De ontwikkeling van de pendelstroom kan in twee perioden worden ingedeeld. In de eerste periode, vanaf het einde van de jaren 1950 tot en met het einde van de jaren 1970, bereikte de

4 Bronnen: DBA Arbeidsmarktbeschrijuing 1960-1985 en CBS, Sociale Maandstatistiek 1970-1983; Idem, Sociaal-Economische Maandstatistiek 1984-2000, http://statline.cbs.nl/Stat/Web/start.asp?LA=nl\&DM=SLN\&lp=Search/Search (cijfer voor 2001); de sterke daling van het CBS-totaal in 1980 hangt hoogstwaarschijnlijk samen met de afwijkende gebiedsindeling in dat jaar (rayon Roermond liet sterke daling zien, terwijl rayons in Noord-Limburg stijging vertoonden; in 1981 werd dit verschil weer rechtgetrokken). Verder wijken de cijfers van het DBA en het CBS tot 1977 sterk van elkaar af. Voor meer informatie over het gebruikte cijfermateriaal: zie appendix A.

5 De inkomende pendel van Belgische mannen (bijna 2.900 in 1959) was in dat jaar bijna in evenwicht met de uitgaande pendel en er werkten nog geen 400 Duitse mannen in Zuid-Limburg (Bron: DBA, Arbeidsmarktbeschrijuing 1959, bijlage tabel 8). Over 1959 zijn er geen cijfers verschenen over het aantal vrouwelijke grensarbeiders (zie ook appendix A).

6 Bron: Idem, Arbeidsmarktbeschrijuing 1960, 53, 62. Op dat moment werkten er bijna 500 Duitse mannen en bijna 150 Duitse vrouwen en ruim 2.800 Belgische mannen en bijna 500 Belgische vrouwen in Zuid-Limburg.

7 Voor het jaar 1958 waren er geen cijfers beschikbaar en voor het jaar 1959 zijn alleen cijfers met betrekking tot mannelijke grensarbeiders gepubliceerd.

8 Voor een overzicht van de belangrijkste maatregelen op dit gebied: zie hoofdstuk 1. 
pendelstroom een relatief grote omvang, zij het met een sterk fluctuerend verloop. In 1973 trad er een kentering op. In dat jaar bereikte het aantal grensarbeiders een hoogtepunt, waarna het onder invloed van de inzettende economische crisis snel afnam om in het begin van de jaren 1980 te stabiliseren rond het niveau van 1967 . In de tweede periode, vanaf de jaren 1980 tot en met 2001, kende de pendelstroom een bescheiden omvang en vertoonde zijn ontwikkeling geen grote uitschieters. ${ }^{9}$

In de volgende paragrafen wordt per periode nagegaan hoe de Duitslandpendel was ingebed in de regionale sociaal-economische context aan weerszijden van de grens en hoe hij zich verhield tot de binnenlandse pendel.

\section{OMVANGRIJKE EN FLUCTUERENDE PENDEL}

\section{Kwantitatieve divergentie}

Tot in de jaren 1950 hielden de sociaal-economische ontwikkelingen in Nederland en Duitsland redelijk gelijke tred. Beide kenden een krappe arbeidsmarkt. In de jaren 1950 maakte de Duitse economie een stormachtige groei door, die bekend staat als het Wirtschaftswunder. Daardoor nam de spanning op de Duitse arbeidsmarkt toe en stegen de lonen. ${ }^{10}$ In het begin van de jaren 1960 lagen de Duitse lonen zo'n 30 tot 50 procent boven die in de Nederlandse grensgebieden, nog los van allerlei toeslagen die de Duitse werkgevers verstrekten. ${ }^{11}$ Dit grote verschil was deels een gevolg van de Nederlandse geleide loonpolitiek, die in het kader van het herstel van de Nederlandse economie na de Tweede Wereldoorlog werd gevoerd. Daarbij werden de Nederlandse lonen tot 1963 kunstmatig laag gehouden om de prijzen van Nederlandse producten te drukken en zo de export weer op gang te helpen. ${ }^{12}$

Onder deze omstandigheden nam het aantal Duitslandgangers snel toe. Volgens het DBA zetten de hoge Duitse lonen veel pendelaars die voorheen in België werkten, ertoe aan om in Duitsland te gaan werken. ${ }^{13}$ Aangezien in het kader van de geleide loonpolitiek ook de kosten van het levensonderhoud in Nederland laag werden gehouden, was de koopkracht van de grenspendelaars in eigen land aanzienlijk. De grensarbeiders konden zo het beste van twee werelden combineren. Mede door de grote uitstroom van arbeidskrachten naar Duitsland kwam het Nederlandse loonbeleid na verloop van tijd onder druk te staan. In het begin van de

92001 is het einde van de onderzoeksperiode. Op dit moment zijn er cijfers beschikbaar tot en met 2005. In dat jaar was het aantal Zuid-Limburgse grensarbeiders gedaald tot iets meer dan 4.500 personen. Sinds 2002 publiceert het CBS geen regionaal uitgesplitste cijfers meer over de inkomende pendel uit Duitsland. In 2005 pendelden er in totaal ruim 15.100 personen vanuit Duitsland naar Nederland. Dit betekent meer dan een verdrievoudiging ten opzichte van 2001 (http://statline.cbs.nl/StatWeb/start.asp?lp=Search/ Search). Vanaf dat moment was voor Nederlandse emigranten hypotheekrenteaftrek mogelijk indien zij in Nederland bleven werken, en zijn er veel Nederlanders naar plaatsen vlak over de Duitse grens gemigreerd, en in Nederland blijven werken (Strüver, 'Transnationalism within the European Union', 332).

10 Thomes, 'Ein Industrierevier im Umbruch', 26. Vgl. de Belgische grensarbeiders die in de jaren na de Tweede Wereldoorlog vanwege het tekort aan arbeidskrachten in Frankrijk gingen pendelen. Belangrijk verschil is echter dat de betaling in Frankrijk relatief laag was als gevolg van de lage koers van de Franse franc. De werkgevers en belangenverenigingen van grensarbeiders wisten daar destijds een compensatie voor af te dwingen (Boutillier et al., Frontaliers du Nord, 151).

11 Bijvoorbeeld de Trennungsentschädigung: een vergoeding voor weekpendelaars. Zie Raad voor het Midden- en Kleinbedrijf (MKB), Rapport inzake de gevolgen van het vrije verkeer, 7, 23, 54 (volgens het Limburgs Dagblad (LD) bedroeg het loonverschil in de bouw aan het einde van de jaren 1950 ongeveer 20-30 procent en kon er in de Duitse mijnbouw meer worden verdiend doordat er met individuele akkoorden in plaats van ploegakkoorden werd gewerkt (LD, 16-8-1957)).

12 Windmuller et al., Arbeidsverhoudingen in Nederland, 161-201; Van Zanden, 'Geleide loonpolitiek'.

DBA, Arbeidsmarktbeschrijuing 1962, 38; Idem, Arbeidsmarktbeschrijuing 1963, 36 . 
jaren 1960 trad er een autonome loonstijging op. In reactie daarop werd het loonbeleid met ingang van 1964 versoepeld. ${ }^{14}$

Aan het einde van de jaren 1950 verwachtte het DBA dat de groei van de pendelstroom op korte termijn zou stagneren, omdat het werken in Duitsland slechts voor een enkeling zou zijn weggelegd. ${ }^{15}$ Het liep echter anders. De loonverschillen vormden niet de enige aanleiding om over de Duitse grens te gaan werken. De pendel kwam tevens voort uit de verslechterende omstandigheden op de Zuid-Limburgse arbeidsmarkt. In 1958 raakte de kolenmarkt in een crisis. Op dat moment werkte ongeveer een derde van de Zuid-Limburgse mannelijke beroepsbevolking in de mijnindustrie. Daarnaast was een groot deel van de beroepsbevolking werkzaam bij gelieerde bedrijven in de metaalindustrie en de bouw. ${ }^{16}$ De Nederlandse mijnen kwamen de problemen niet meer te boven. Gaandeweg werd duidelijk dat zij zich in een uitzichtloze situatie bevonden. Tussen 1958 en 1965 gingen in de mijnbouw al ruim 10.000 arbeidsplaatsen verloren. ${ }^{17}$ Veel, overwegend jongere, mannen zagen geen toekomst meer in de Nederlandse mijnen. Het ondergrondse werk kampte met een imagoprobleem en de mijnbedrijven boden niet langer het vaste werk waar ze eerder om bekend hadden gestaan. ${ }^{18}$ Vanwege de eenzijdige werkgelegenheidsstructuur was het evenwel moeilijk om in Zuid-Limburg ander werk te vinden. Tegelijkertijd was er aan Duitse zijde van de grens volop werk tegen een uitstekende betaling. Het was dus buitengewoon aantrekkelijk om in Duitsland te gaan werken. De uitstroom van mijnwerkers nam zulke grote vormen aan dat de mijnbedrijven, die jongere mannen nodig hadden om de kolenproductie op peil te houden, zich genoodzaakt zagen jonge arbeidskrachten uit bijvoorbeeld Italië en Joegoslavië aan te trekken om de ontstane leemtes op te vullen. ${ }^{19}$

In reactie op de aanhoudende problemen ontvouwde de Nederlandse regering in 1965 plannen om de mijnbouwactiviteiten geleidelijk af te bouwen. In 1974 beëindigden de laatste twee mijnen hun kolenwinning. ${ }^{20}$ De mijnsluitingen betekenden een enorme aderlating voor de Zuid-Limburgse arbeidsmarkt. Alleen al in de mijnindustrie gingen zo'n 45.000 arbeidsplaatsen verloren. ${ }^{21}$ In het kielzog van de mijnsluitingen verdwenen er tevens duizenden banen bij aanverwante bedrijfstakken. Om massale werkloosheid te voorkomen probeerde de regering het sluitingsproces zo veel mogelijk te sturen en met subsidies nieuwe werkgevers aan te trekken. Al gauw werd echter duidelijk dat deze herstructureringsoperatie geen onverdeeld succes was. Tussen 1965 en 1974 was de nieuw gecreëerde werkgelegenheid ontoereikend om het banenverlies in de mijnindustrie op te vangen. ${ }^{22}$ De oorzaken daarvoor lagen in de ongunstige conjuncturele situatie en het aantrekken van weinig kansrijke industrie. ${ }^{23}$ 
De problemen op de kolenmarkt lieten ook het aangrenzende Duitse gebied niet onberoerd. In de huidige Regio Aken leidden zij tot de sluiting van een drietal mijnen in het begin van de jaren 1960. Andere Duitse mijnen werden draaiende gehouden met rationaliseringsoperaties en overheidssubsidies. ${ }^{24}$ Daarnaast probeerde de overheid in Noordrijn-Westfalen (NRW) nieuwe banen te scheppen door investeringspremies uit te loven aan ondernemingen in andere bedrijfstakken, zoals de metaalindustrie, de chemie en de machinebouw. Vergeleken met Zuid-Limburg hadden de problemen in de Duitse mijnbouw minder consequenties voor de regionale arbeidsmarkt, omdat de werkgelegenheidsstructuur van het Duitse grensgebied veel diverser was. Naast acht mijncomplexen zetelden er in de hedendaagse Regio Aken talloze bedrijven in de bouw-, metaal-, textiel-, papier-, glas- en zoetwarennijverheid. Hoewel de oudere metaal- en textielfabrieken in het begin van de jaren zestig eveneens in moeilijkheden verkeerden, was er voldoende werkgelegenheid bij nieuwere, deels met overheidsgelden aangetrokken bedrijven in de metaalindustrie en de machinebouw om deze op te vangen. ${ }^{25}$

In 1965 bereikte het aantal Duitslandgangers een eerste naoorlogse piek van bijna 9.500 personen. Daarmee was 4 procent van de Zuid-Limburgse beroepsbevolking in Duitsland werkzaam. In 1966 en 1967 makkte de economie zowel aan Nederlandse als Duitse zijde van de grens een recessie door. Aan Duitse zijde van de grens ging veel werkgelegenheid verloren in de bouwnijverheid, en door automatiseringsprocessen evenzo in de textiel-, metaal-, rubber- en steenindustrie. ${ }^{26}$ Dat vertaalde zich in een kelderend aantal grenspendelaars. De pendelstroom slonk ongeveer éénderde tot bijna 6.500. Het DBA beschouwde dit als een harde kern. Met andere woorden: tweederde van de arbeidsstroom vanuit Limburg naar Duitsland zou een structureel, oftewel blijvend, karakter hebben aangenomen. ${ }^{27}$

De arbeidsmarkt in het Duitse grensgebied trok snel weer aan. De werkgelegenheidsgroei was onder meer het resultaat van een bouwhausse. ${ }^{28}$ In het begin van de jaren 1970 deed de bouw van het Olympisch complex in München daar nog een schepje bovenop. Deze trok bouwvakarbeiders uit het Duitse grensgebied aan, die gedeeltelijk werden vervangen door Zuid-Limburgse grensarbeiders. ${ }^{29}$ In dezelfde periode nam de bouwactiviteit in Zuid-Limburg sterk af. ${ }^{\circ}$ Behalve in de bouw werden er in en rond de stad Aken grote omzetten geboekt in de chemie, de machinebouw en de metaalindustrie. ${ }^{31}$ De spanning op de arbeidsmarkt nam sterk toe. In 1973 zou de vraag naar jonge vakmensen zelfs drie maal zo groot zijn geweest als het aanbod. ${ }^{22}$ Duitse werkgevers trachtten de tekorten aan werknemers onder meer op te vangen via de werving van gastarbeiders uit het Mediterrane gebied en de inzet van Nederlandse grensarbeiders. ${ }^{33}$ In het voorjaar van 1973 werkten er volgens het Landesarbeitsamt 679.000 buitenlandse arbeidskrachten in Noordrijn-Westfalen, waaronder 23.000 Limburgers. In het arbeidsmarktdistrict Aken bedroeg het aandeel buitenlandse arbeidskrachten op dat moment

24 Zillinger, Regionalwirtschaftlicher Strukturwandel, 11, 67-69, 75 (vanaf het einde van de jaren 1950 tot het einde van de jaren 1960 gingen er in heel NRW zo'n 170.000 banen verloren in de mijnbouw).

25 Ibidem, 69-70; Thomes, 'Ein Industrierevier im Umbruch', 25.

26 Ibidem, 28-29, 32.

27 DBA, Arbeidsmarktbeschrijuing 1967, 68; Idem, Arbeidsmarktbeschrijuing 1968, 57.

28 Schüssler en Koof, 'Bauwirtschaft', 310-313.

29 CBS, Sociale maandstatistiek 1972/6, 296. Overigens veroorzaakte het gereedkomen van dit project in 1972 geen afnemende vraag naar bouwvakarbeiders uit Zuid-Limburg (DBA, Arbeidsmarktbeschrijuing 1972, 52-53).

30 DBA, Arbeidsmarktbeschrijuing 1971, 57; Idem, Arbeidsmarktbeschrijuing 1973, 54; LD, 8-7-1970.

31 Thomes, 'Ein Industrierevier im Umbruch', 30.

32 Districtsvoorzitter van het Nederlandse Katholieke Vakverbond (NKV), Weijers, in De Limburger (DL), 30-5-1973.

Thomes, 'Ein Industrierevier im Umbruch', 30. 
bijna 14 procent en in de districten Krefeld en Mönchengladbach ongeveer 12 procent. ${ }^{34} \mathrm{Ge}$ zien de grootscheepse inzet van gastarbeiders vulden de grensarbeiders bij lange na niet alle vrijgekomen arbeidsplaatsen op. ${ }^{35}$

Door de extreme krapte op de arbeidsmarkt bleven de Duitse lonen hoger dan de Nederlandse. In 1971 lagen de bruto-uurlonen in de nijverheidssector van de deelstaat NoordrijnWestfalen ongeveer éénderde boven die aan Nederlandse zijde van de grens. Dit verschil kon nog oplopen door hoge prestatiebeloningen en ruime mogelijkheden tot overwerk in Duitsland..$^{36}$ Mede daardoor werd het loonverschil in Limburg, ook door de grensarbeiders zelf, als nog groter ervaren. ${ }^{37}$ Door de revaluatie van de Duitse mark in 1973 steeg het inkomen van de grensarbeiders in guldens daarnaast nog eens met 5 tot 10 procent..$^{8}$

$\mathrm{Nu}$ kwam de Duitslandpendel pas echt op gang. Geprikkeld door de sterke push van de verslechterende en onzekere arbeidsmarktsituatie in Zuid-Limburg en de krachtige pull die uitging van de grote vraag naar arbeidskrachten en de bijgevolg hoge lonen over de Duitse grens, nam het aantal grensarbeiders explosief toe. ${ }^{39}$ In 1973 bereikte de pendelstroom een naoorlogse recordomvang van net geen 16.900 personen. Dat was 6 procent van de Zuid-Limburgse beroepsbevolking. Ter vergelijking: op dat moment werkten er amper 1.200 Zuid-Limburgse grensarbeiders in België, en bijna 300 Duitsers en iets meer dan 5.300 Belgen in ZuidLimburg..$^{40}$ Vanwege de uittocht van grensarbeiders uit de Zuid-Limburgse mijnen moesten deze nog steeds gastarbeiders, nu uit onder meer Marokko, aantrekken om de kolenproductie tot de geplande einddatum te kunnen voortzetten. ${ }^{41}$ Desalniettemin was de regionale werkloosheid relatief hoog. In 1966 lag de werkloosheid in Zuid-Limburg al iets boven het landelijk gemiddelde, om het tijdens de recessie van 1966 en 1967 ruim te overtreffen en in 1973 op bijna 5 procent uit te komen, éénderde boven het landelijk gemiddelde. In totaal zaten er in 1973 ongeveer 12.700 Zuid-Limburgers zonder werk.42 Ondanks de werkloosheid zag ook de in het kader van de herstructurering naar Zuid-Limburg overgeplaatste autofabriek DAF zich in het begin van de jaren 1970 genoodzaakt werknemers uit het buitenland te halen.43

\footnotetext{
34 Zie LD, 29-5-1973b.

35 Vgl. Boutillier et al. (Frontaliers du Nord, 153-154) die constateerden dat de vraag naar Belgische grensarbeiders in Frankrijk daalde door de komst van de gastarbeiders in de jaren 1960. Dat is bij de Zuid-Limburgse pendelaars in Duitsland niet terug te zien (zie ook hoofdstuk 5 waarin krantenartikelen worden aangehaald waarin Duitse autoriteiten stelden dat grensarbeiders goedkoper waren dan gastarbeiders). 36 Van den Berg et al., De grenspendel in Limburg, 51-52: benadering van het beloningsverschil tussen Limburg en de Duitse attractiegebieden op basis van de Nederlandse bruto-uurlonen buiten de Randstadprovincies (Noord-Holland, Zuid-Holland, Utrecht), en de bruto-uurlonen in de deelstaat Noordrijn-Westfalen; zie ook minister Roolvink in Limburgs Dagblad (LD, 14-1-1971)

37 Van den Berg et al., De grenspendel in Limburg, 58-59, 94.

38 Minister Boersma van Sociale Zaken in De Limburger (DL, 4-7-1973; zie ook LD, 11-7-1973; DL, 9-8-1973).

39 Zie ook bijvoorbeeld DBA, Arbeidsmarktbeschrijuing 1972, 57.

40 DBA, Arbeidsmarktbeschrijuing 1973, bijlage tabel 2a en 3a. Ook nationaal gezien was het aantal pendelaars naar Duitsland in ZuidLimburg groot. In het begin van de jaren 1970 woonde ongeveer de helft van alle Nederlandse Duitslandgangers in Zuid-Limburg (Zie CBS, Sociale Maandstatistiek 1970/11; Idem, Sociale Maandstatistiek 1973/1, Idem, Sociale Maandstatistiek 1974/2). Bovendien was de eenzijdigheid van de grenspendel zowel in de jaren 1970 als in de jaren 1990 kenmerkend voor de grenspendel in heel Europa (zie Ricq, Les travailleurs frontaliers, 12-13; Soutif, L'intégration européenne, 361).

41 Messing, Geschiedenis van de mijnsluiting, 183, 405; Cranssen, 'Marokkaanse mijnwerkers in Limburg', 123-129.

42 Derks, Zuid-Limburg, 37 (N.B. Het betreft hier het aantal werklozen als percentage van de afhankelijke beroepsbevolking. Dit cijfer is dus niet één op één te vergelijken met het percentage grensarbeiders van de totale beroepsbevolking).

43 Zie minister Boersma van Sociale Zaken in De Limburger (DL, 31-5-1972). Het DBA wees er herhaaldelijk op dat er door de pendel naar Duitsland werknemerstekorten ontstonden die gedeeltelijk werden opgevuld met Belgische grensarbeiders (DBA, Arbeidsmarktbeschrijuing 1963, 37; Idem, Arbeidsmarktbeschrijuing 1969, 55; Idem, Arbeidsmarktbeschrijuing 1970, 53). De Belgen werkten echter hoofdzakelijk in Maastricht (in 1965 bijna 80 procent, zo'n 3.600 pendelaars; in 1973 driekwart, zo'n 4.500), waar het aantal Duitslandgangers relatief klein was (in 1965 en in 1973 zo'n 1.300). Bovendien betrof de pendel uit België relatief veel vrouwen, behoorden zij tot andere leeftijdscategorieën, en werkten zij veelal in andere sectoren dan de Duitslandgangers, waardoor er niet echt van compensatie kan worden gesproken (zie cijfers in DBA, Arbeidsmarktbeschrijuing 1965, bijlage tabel 8, 9 en 15; Idem, Arbeidsmarktbeschrijuing 1973, bijlage tabel 2a en 3a; zie ook CBS, Sociale Maandstatistiek 1972/6, 296, 302-303).
} 


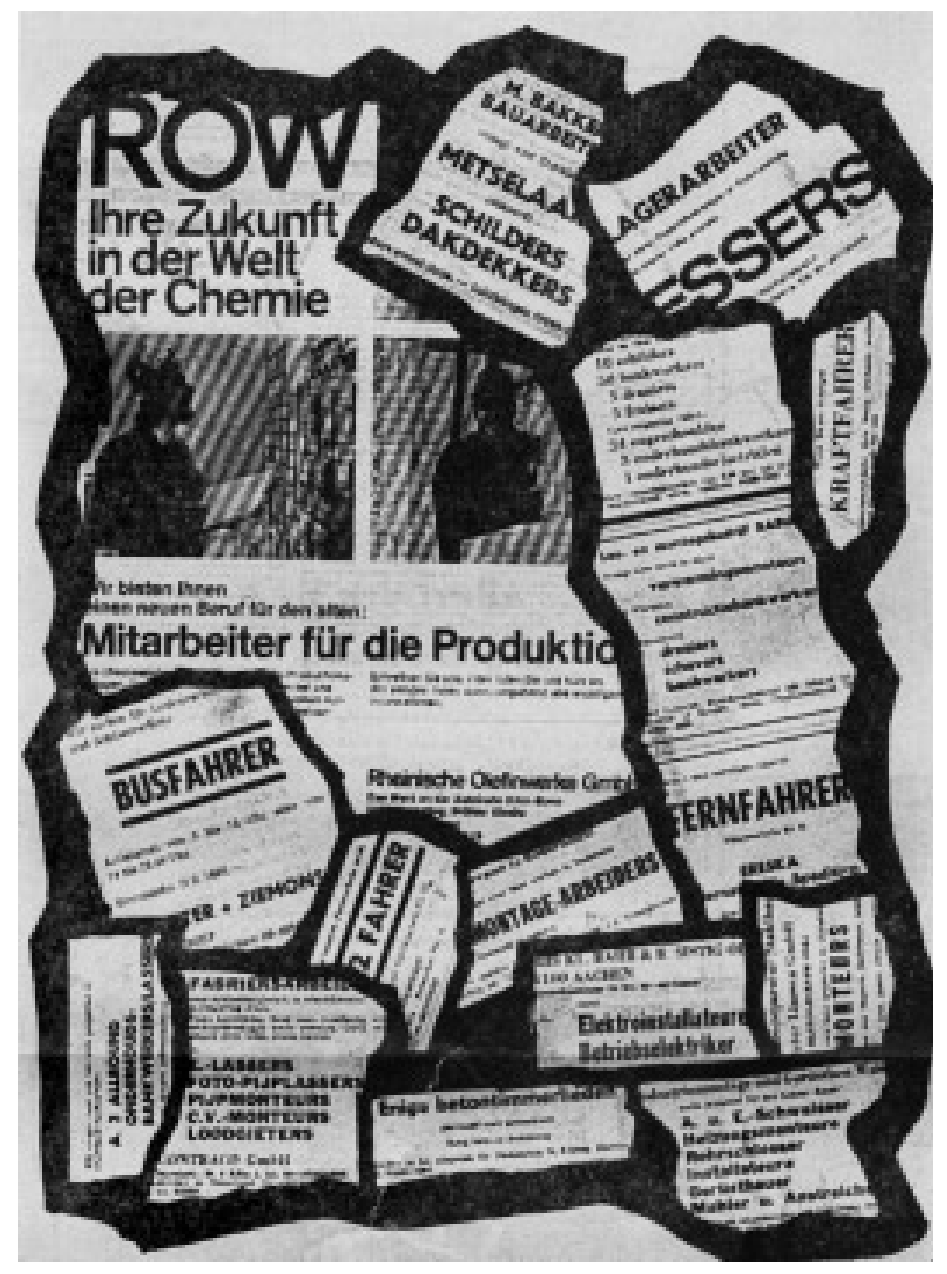

Collage van personeelsadvertenties van Duitse bedrijuen. Deze advertenties waren verschenen in Limburgs Dagblad, 7-7-1973 (bouwvakzaterdag) (Bron: LD, 11-71973).

De eerste oliecrisis van 1973 vormde de voorbode van een zware economische depressie die voortduurde tot in de jaren 1980 . Vooral de industrie kreeg in deze periode grote verliezen te verwerken. Aan beide zijden van de grens groeide de werkloosheid sterk. ${ }^{44} \mathrm{Na} 1973$ nam het loonverschil tussen Nederland en Duitsland af tot ongeveer 12 procent in 1975, om vervolgens weer licht te stijgen tot 16 procent in $1979 .{ }^{45}$ Onder deze condities liep de Duitslandpendel drastisch terug. Op basis van cijfers over de periode tot en met 1975 stelde de commissie die belast was met de voortzetting en aanpassing van het herstructureringsbeleid voor Zuid-Limburg, nog dat er een 'harde kern [van pendelaars] met een behoorlijke omvang' was ontstaan. ${ }^{46}$ De inkrimping van de pendelstroom hield echter tot het einde van de jaren 1970 aan, om in 1979 uit te komen op een kleine 6.90o grensarbeiders, vergelijkbaar met het niveau van

44 Thomes, 'Ein Industrierevier im Umbruch', 33; Derks, Arbeidsmarkt Herstruktureringsgebied, 20.

45 Derks, Pendel 1973-1979, 68; hoewel Derks verwijst naar de berekening van het NEI, gebruikt hij landelijke cijfers, terwijl het NEI lonen in bijvoorbeeld de Randstad buiten beschouwing liet en voor Duitsland alleen de lonen in Noordrijn-Westfalen gebruikte (Van den Berg et al., De grenspendel in Limburg, 51-52).

46 Coördinatiecommissie Perspectievennota, Concept perspectievennota, 47. 
1967. In zes jaar tijd was het aantal grensarbeiders dus meer dan gehalveerd. ${ }^{47}$ Aan het einde van de jaren 1970 werkte nog slechts 3 procent van de Zuid-Limburgse beroepsbevolking in Duitsland. De massale terugkeer van de grenspendelaars vergrootte de reeds stijgende regionale werkloosheid. In 1979 bedroeg het regionale werkloosheidspercentage met bijna 13 procent ongeveer het dubbele van het landelijk gemiddelde. ${ }^{48}$ Ook de huidige Regio Aken kampte met betrekkelijk veel werklozen. Het werkloosheidspercentage was ongeveer anderhalve keer zo groot als het nationaal gemiddelde. ${ }^{49}$

De relatief grote, weliswaar fluctuerende, omvang die de grenspendel vanuit Zuid-Limburg naar Duitsland tussen het einde van de jaren 1950 en het einde van de jaren 1970 bereikte, hing dus samen met een aanzienlijke kwantitatieve discrepantie tussen de arbeidsmarktomstandigheden aan weerszijden van de grens. Deze ging hand in hand met een uitstekende aansluiting in kwalitatief opzicht. Het groeiende arbeidsaanbod in Zuid-Limburg matchte qua opleiding en werkervaring, geslacht en leeftijd, bijzonder goed met de openstaande vraag in het aangrenzende Duitse gebied.

\section{Kwalitatieve aansluiting}

De verdeling naar bedrijfstak

De crisis in de mijnbouw en de daarop volgende mijnsluitingen zetten veel Zuid-Limburgers ertoe aan op zoek te gaan naar ander werk. Een deel van hen stapte over naar de Duitse mijnen. In 1960 werkte ongeveer een vijfde deel van de grensarbeiders in de mijnindustrie..$^{\circ}$ Mede door het verdwijnen van werkgelegenheid in de Duitse mijnbouw daalde dit aandeel vervolgens om in 1973 op ongeveer 3 procent uit te komen. ${ }^{51}$ Het absolute aantal grensarbeiders in de mijnbouw bereikte in 1963 haar hoogtepunt met bijna 1.300 pendelaars en nam sindsdien af tot iets minder dan 500 pendelaars in $1973 . .^{22}$

De Zuid-Limburgse pendelaars vonden dus bij lange na niet allemaal emplooi in de Duitse mijnbouw. Zij werkten hoofdzakelijk in andere vormen van nijverheid, vooral in de expanderende bouwsector (zie figuur 4.2).

\footnotetext{
47 De daling van het aantal Duitslandgangers was in Zuid-Limburg naar verhouding iets kleiner dan in andere delen van Nederland. In 1973 bestond 45 procent van de Nederlandse pendelstroom naar Duitsland uit Zuid-Limburgers, terwijl dit aandeel in 197955 procent bedroeg (CBS, Sociale Maandstatistiek 1974/2; Idem, Sociale Maandstatistiek 1979/11, 862-864 (berekening: SB). Vgl. de daling van het aantal Belgische pendelaars in Frankrijk als gevolg van de economische achteruitgang in de jaren 1970 (Boutillier et al., Frontaliers du Nord, 153).

48 Messing, Geschiedenis van de mijnsluiting, 473-474; Derks, Zuid- Limburg, 37 (N.B. Het betreft hier het aantal werklozen als percentage van de afhankelijke beroepsbevolking. Dit cijfer is dus niet één op één te vergelijken met het percentage grensarbeiders van de totale beroepsbevolking). Het absolute aantal werklozen in 1979 noemt hij helaas niet. Dat van 1978 wel: in dat jaar waren 28.400 personen werkloos.

49 Thomes, 'Ein Industrierevier im Umbruch', 41. Het exacte cijfer noemt hij helaas niet.

50 Bron: DBA, Arbeidsmarktbeschrijuing 1960, bijlage tabel d.b.a. 8 (berekening: SB) (hierbij is ervan uitgegaan dat er net als in de jaren daarna geen vrouwen in de Duitse mijnbouw werkten).

51 Bron: Idem, Arbeidsmarktbeschrijuing 1973, bijlage tabel 12 (berekening: SB).

52 Bron: Idem, Arbeidsmarktbeschrijuing 1963, bijlage tabel 18; Idem, Arbeidsmarktbeschrijuing 1973, bijlage tabel 12.
} 


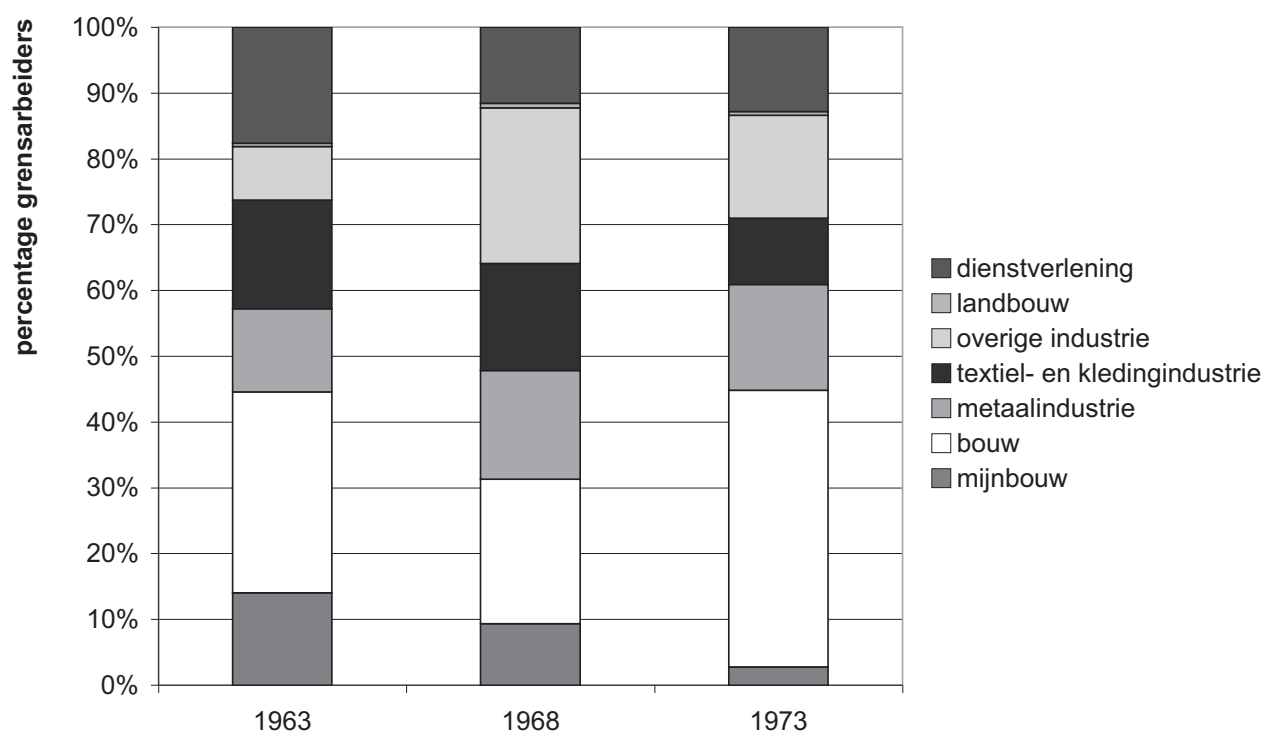

Duitsland maakte zoals gezegd een bouwhausse door. Doordat de orderportefeuille van veel Limburgse bouwbedrijven in het begin van de jaren 1970 kromp, gingen niet alleen werknemers, maar ook werkgevers hun heil in Duitsland zoeken. ${ }^{54}$ Behalve in de bouw waren er veel grensarbeiders actief in de metaalindustrie en de textiel- en kledingindustrie..$^{55}$

Het vrijkomende contingent laag opgeleide Zuid-Limburgse mijnwerkers was bijzonder goed inzetbaar in de Duitse nijverheid. Dat vooral lager opgeleiden naar Duitsland forensden, blijkt uit de enquête van het Nederlands Economisch Instituut (NEI) uit het begin van de jaren 1970. Van de ondervraagde mannelijke Duitslandgangers had ruim een kwart uitsluitend lager onderwijs gevolgd, terwijl iets meer dan 60 procent een lagere beroepsopleiding had afgerond. Slechts zo'n 10 procent had een middelbaar opleidingsniveau en nog geen 3 procent had een hogere beroepsopleiding of een universitaire studie genoten..$^{6}$

De sterke fluctuaties in het verloop van de pendelstroom kunnen grotendeels worden toegeschreven aan het omvangrijke segment grensarbeiders in de conjunctuurgevoelige bouwsector. ${ }^{57}$ Behalve conjunctuurgevoelig was het werk in de bouwsector ook seizoensgebonden. In de winter lagen de werkzaamheden grotendeels stil. Dit uitte zich in een teruglopend aantal

53 Bron: Idem, Arbeidsmarktbeschrijuing 1963, bijlage tabel 18; Idem, Arbeidsmarktbeschrijuing 1968, bijlage tabel 12; Idem, Arbeidsmarktbeschrijuing 1973, bijlage tabel 12 (berekening: SB).

54 Idem, Arbeidsmarktbeschrijuing 1972, 52-53; zie ook LD, 30-11-1971. Personen die voor een in Nederland gevestigd bedrijf in Duitsland werkten, zijn echter waarschijnlijk niet meegenomen in de cijfers van het DBA en zeker niet in die van het CBS (zie ook appendix A).

55 In de jaren 1990 gaf een vertegenwoordiger van de wagonfabriek Talbot aan dat in contracten met de Nederlandse Spoorwegen werd opgenomen dat het bedrijf de werkgelegenheid voor Nederlanders in het bedrijf moest stimuleren. Het is helaas niet helemaal duidelijk welke periode dit betreft (Van Goethem en Doumen, Grensarbeid in de Euregio Maas-Rijn, 132; zie ook Indetzki, 'Branchenvielfalt in der Region', 373). In de jaren 1970 was er overigens in heel Europa sprake van een oververtegenwoordiging van grensarbeiders in de nijverheid (L'intégration européenne, 297). Vgl. ook de Belgische grensarbeiders in Frankrijk die in deze periode in dezelfde bedrijfstakken werkzaam waren (Boutillier et al., Frontaliers du Nord, 152-153).

56 Hendriks et al., De gevolgen van pendel op Duitsland, B21.

57 Over de afname van het aantal grensarbeiders in de bouw ten tijde van de recessie van 1966/67 zie CBS Sociale Maandstatistiek $1972 / 6,298$. 


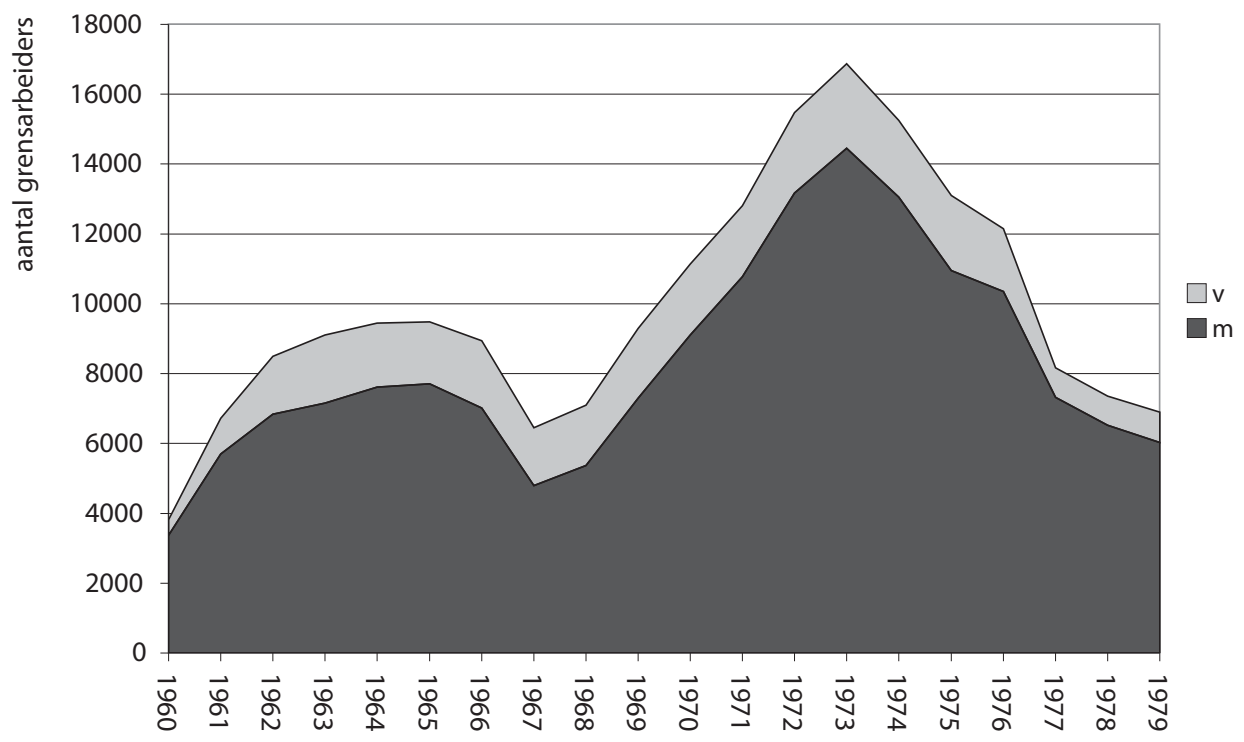

grensarbeiders in de wintermaanden. ${ }^{59}$ De pendelstroom in de Duitse metaal- en andere industrie kende een grotere mate van stabiliteit. Toch was er ten tijde van de recessie in 1966 en 1967 door kostenbesparende automatiseringsprocessen eveneens sprake van een teruggang van het aantal pendelaars in de textiel- en metaalindustrie. Als gevolg van de crisis die in 1973 inzette, zag de traditionele industrie, zoals de textiel- en de papierindustrie, zich genoodzaakt het productieproces te rationaliseren, waardoor er opnieuw veel banen verloren gingen. Doordat er ook in de bouw veel werkgelegenheid verdween, bleef de verdeling van de grensarbeiders naar bedrijfstak in 1974 ongeveer gelijk aan die in de jaren daarvoor. Met ingang van 1975 zijn er geen specifieke regionale cijfers meer beschikbaar over de verdeling van de grensarbeiders naar bedrijfstak. Uit cijfers over alle in Nederland woonachtige Duitslandgangers blijkt dat in 1979 nog 35 procent van de Nederlandse grenspendelaars in de bouw werkte. Daarnaast had 20 procent een betrekking in de metaalindustrie en 4 procent in de kleding- en textielindustrie ${ }^{60}$

\section{De verdeling naar geslacht en leeftijd}

In bedrijfstakken als de bouw en de metaalindustrie zijn overwegend mannen werkzaam. De meeste grensarbeiders waren dan ook van het mannelijk geslacht. De sterke groei en schommeling van de omvang van de pendelstroom kwamen hoofdzakelijk voor hun rekening (zie figuur $4 \cdot 3) .{ }^{61}$

58 Bron: DBA Arbeidsmarktbeschrijuing 1960-1979 ( $\mathrm{m}=$ mannen; $\mathrm{v}=$ vrouwen).

59 In 1972 en 1973 liep het aantal Nederlandse grensarbeiders vanaf januari tot en met maart bijvoorbeeld terug met ongeveer 6 tot 8 procent, om vervolgens weer toe te nemen (alleen over het begin van de jaren 1970 zijn er maandelijkse cijfers beschikbaar over het aantal grensarbeiders dat vanuit Nederland in Duitsland werkte) (bron: CBS, Sociale Maandstatistiek 1972/3, 145; Idem, Sociale Maandstatistiek 1973/1, 14 (berekening: SB).

6o Bron: CBS, Sociale Maandstatistiek 1979/11, 861 (berekening: SB).

61 Zie ook Hendriks et al., De gevolgen van de pendel op Duitsland, 5. Ook wat betreft het grote aandeel mannen blijkt de arbeidsstroom vanuit Zuid-Limburg in de jaren 1970 niet af te wijken van de rest van Europa (Soutif, L'intégration européenne, 297). 
Het aantal vrouwelijke grensarbeiders was erg klein. Zij werkten meestal in de textiel- en kledingindustrie, waar zij het aantal mannen ongeveer evenaarden. In tijden van conjuncturele teruggang verloren echter meer vrouwen dan mannen hun baan in deze bedrijfstak.

De vrouwelijke grensarbeiders waren over het algemeen jonger dan de mannelijke (zie tabel 4.1). Van alle Nederlandse vrouwen die in Duitsland werkten, was in de jaren 1960 ruim 80 procent jonger dan 30 jaar. Dit aandeel nam in de jaren 1970 geleidelijk af om in 1979 op iets minder dan de helft uit te komen. Bij de mannen bedroeg het aandeel pendelaars jonger dan 30 jaar in de jaren 1960 bijna de helft en in het begin van de jaren 1970 zelfs meer dan de helft. Mogelijk was het aandeel jongeren in Zuid-Limburg groter dan landelijk. Onder de Limburgse grensarbeiders die het NEI in 1972 enquêteerde, was éénderde van degenen die in de industrie werkten jonger dan 25 jaar, terwijl in de bouw en overige bedrijfstakken respectievelijk 29 en 24 procent jonger dan 25 was. In tegenstelling tot de vrouwelijke grensarbeiders had de meerderheid van de geënquêteerde mannelijke Duitslandgangers een gezin. ${ }^{62}$ In die tijd was het voor gehuwde Zuid-Limburgse vrouwen niet gebruikelijk om er een betaalde baan op na te houden. ${ }^{63} \mathrm{Na} 1973$ nam het aandeel mannelijke grenspendelaars dat jonger was dan 30 jaar nationaal gezien snel af tot ongeveer een kwart in 1979 (zie tabel 4.1). Alle leeftijdscategorieen kenden een dalend aantal pendelaars, maar onder de jongeren verliep de afname sneller dan onder ouderen. ${ }^{64}$ De veroudering van de grensarbeiders duidt op een gebrek aan jonge aanwas. ${ }^{65}$

TABEL 4.1 GRENSARbEIDERS Uit NEDERLAND IN DUITSLAN D NAAR LEEFTIJD EN GESLACHT, 1963, 1967, 1971, 1975, 1979. ${ }^{66}$

\begin{tabular}{|c|c|c|c|c|c|c|c|c|c|c|c|c|c|c|}
\hline & \multicolumn{2}{|c|}{$\begin{array}{l}<21 \mathrm{jr} \\
(\%)\end{array}$} & \multicolumn{2}{|c|}{$\begin{array}{l}21-29 \mathrm{jr} \\
(\%)\end{array}$} & \multicolumn{2}{|c|}{$\begin{array}{l}30-39 \mathrm{jr} \\
(\%)\end{array}$} & \multicolumn{2}{|c|}{$\begin{array}{l}40-49 \mathrm{jr} \\
(\%)\end{array}$} & \multicolumn{2}{|c|}{$\begin{array}{l}>49 \mathrm{jr} \\
(\%)\end{array}$} & \multicolumn{2}{|c|}{$\begin{array}{l}\text { totaal } \\
(\%)\end{array}$} & \multicolumn{2}{|l|}{$\begin{array}{l}\text { totaal } \\
\text { (abs.) }\end{array}$} \\
\hline & $\mathbf{m}$ & $\mathbf{v}$ & $\mathrm{m}$ & $\mathbf{v}$ & m & $\mathbf{v}$ & $\mathbf{m}$ & $\mathbf{v}$ & m & $\mathbf{v}$ & $m$ & $v$ & $\mathrm{~m}$ & $v$ \\
\hline 1963 & 15 & 55 & 32 & 28 & 25 & 8 & 17 & 6 & 10 & 3 & 100 & 100 & 13.435 & 3.273 \\
\hline 1967 & 15 & 52 & 33 & 31 & 24 & 7 & 17 & 6 & 10 & 3 & 100 & 100 & 14.733 & 3.714 \\
\hline 1971 & 10 & 38 & 43 & 39 & 27 & 8 & 14 & 9 & 7 & 7 & 100 & 100 & 20.676 & 2.251 \\
\hline 1975 & 5 & 20 & 37 & 49 & 36 & 14 & 15 & 9 & 7 & 9 & 100 & 100 & 19.517 & 1.871 \\
\hline 1979 & 3 & 9 & 23 & 40 & 43 & 25 & 22 & 14 & 9 & 11 & 100 & 100 & 11.179 & 1.283 \\
\hline
\end{tabular}

Het snel krimpende aandeel jongeren is te verklaren uit de problemen in de kleding- en textielindustrie en de bouw- en metaalnijverheid, waar respectievelijk veel jonge Nederlandse vrouwen en mannen werkten. ${ }^{67}$ In de literatuur wordt de daling van het percentage jongeren ook in verband gebracht met het sterk afnemende loonverschil voor jongeren, als gevolg van de introductie van een minimumjeugdloon in Nederland. ${ }^{68}$

62 Van den Berg et al., De grenspendel in Limburg, 82-83 (70 procent van de ondervraagde grensarbeiders was gezinshoofd, 3 procent huisvrouw, 21 procent zoon en 4 procent dochter).

63 Wijers, 'In de schaduw van het kruis', 51-57.

64 Ook dit stemt overeen met het Europese beeld (Soutif, L'intégration européenne, 297).

65 Zie Derks, Pendel 1973-1979, 11, 13.

66 Bron: 1963, 1967: CBS, Sociale Maandstatistiek 1972/6, 300; 1971, 1975, 1979: Idem, Sociale Maandstatistiek 1972/3, 145; Idem, Sociale Maandstatistiek 1975/11, 675 en Idem, Sociale Maandstatistiek 1979/11, 861 (berekening: SB; percentages afgerond op hele getallen (halven naar boven afgerond). Door afrondingsverschillen komen de opgetelde weergegeven percentages niet altijd exact op 100 uit. Deze cijfers betreffen alle Nederlandse grensarbeiders, maar worden wel als indicatief beschouwd voor de grensarbeiders uit Zuid-Limburg. Over 1968 zijn geen cijfers beschikbaar. Om die reden is hier gekozen voor een interval van vier in plaats van vijf jaar.

67 Zie CBS, Sociale Maandstatistiek 1975/11, 675 en Idem, Sociale Maandstatistiek 1979/11, 861.

68 Derks, Pendel 1973-1979, 13. 


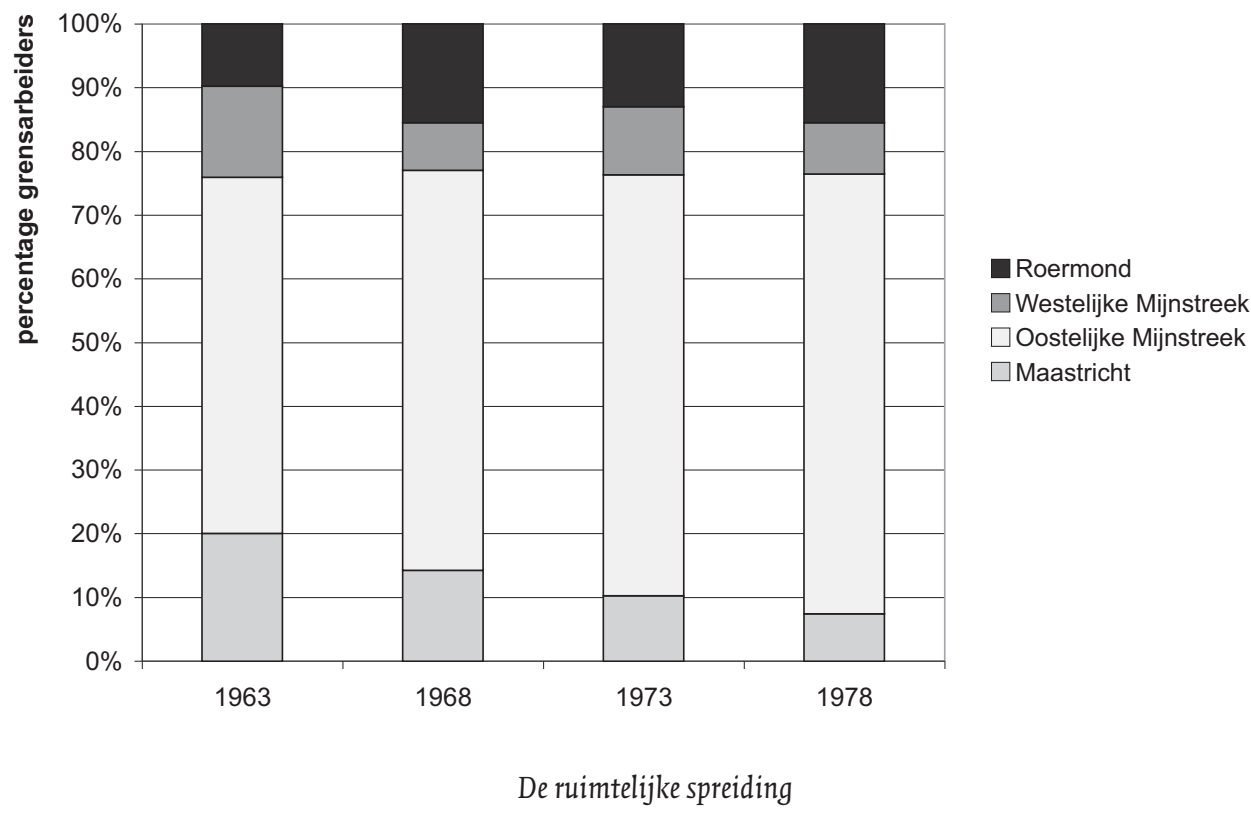

In de gehele periode tot en met het einde van de jaren 1970 woonde ongeveer tweederde van alle grensarbeiders in de Oostelijke Mijnstreek (zie figuur 4.4). ${ }^{70} \mathrm{Het}$ arbeidsaanbod in dit gebied paste zowel kwantitatief als kwalitatief gezien zeer goed bij de vraag naar arbeidskrachten in Duitsland. De Oostelijke Mijnstreek had elf van de twaalf mijnzetels gehuisvest, die in 1965 nog werk boden aan ongeveer de helft van de mannelijke beroepsbevolking..$^{71}$ Door haar opleidingsniveau en werkervaring was de beroepsbevolking uit de Oostelijke Mijnstreek bij uitstek geschikt voor de functie van handarbeider. In het begin van de jaren 1960 kende dit gebied samen met het landelijke Heuvelland ${ }^{72}$ het laagste opleidingsniveau van Zuid-Limburg. Ongeveer tweederde van de mannelijke beroepsbevolking had uitsluitend de lagere school doorlopen. ${ }^{73}$ Een decennium later was dit aandeel in de Oostelijke Mijnstreek gedaald tot 37 procent. Op dat moment had echter nog ruim 9o procent van de mannelijke beroepsbevolking maximaal lager voortgezet of lager beroepsonderwijs genoten..$^{74}$

69 Bron: DBA, Arbeidsmarktbeschrijuing 1963, bijlage tabel 8 en 9; Idem, Arbeidsmarktbeschrijuing 1968, bijlage tabel 2 en 3; Idem Arbeidsmarktbeschrijuing 1973, bijlage tabel 2 a den 3a; Idem, Arbeidsmarktbeschrijuing 1978, tabel 3.9 (berekening: SB). Er vond in deze periode een aantal veranderingen plaats in de gebiedsindeling die het DBA hanteerde. Het rayon Vaals behoorde in 1963 tot het gewest Maastricht en vanaf 1965 tot de Oostelijke Mijnstreek. Verder behoorde het rayon Echt in 1963 tot het gewest Westelijke Mijnstreek, terwijl het met ingang van 1965 deel uitmaakte van het gewest Roermond. Dit kan de afname van het aandeel pendelaars uit het gewest Maastricht en de Westelijke Mijnstreek in 1968 verklaren (zie ook appendix A).

70 Oftewel de rayons Kerkrade, Heerlen en Brunssum.

71 Messing, Geschiedenis van de mijnsluiting, 373.

72 Destijds 'Recreatiegebied Zuid-Limburg' genoemd.

73 Bron: Provinciale Planologische Dienst in Limburg, Limburg in 1960, 20.

74 Daarmee lag het percentage lager opgeleiden in de OM iets boven dat in de rest van Zuid-Limburg (bron: Hendriks et al., De gevolgen van de pendel op Duitsland, B22). 
FiguUR 4.5 Grensarbeiders uit Zuid-Limburg nAAR DUitse Werkrayons, $1970,1973,1978 .{ }^{75}$

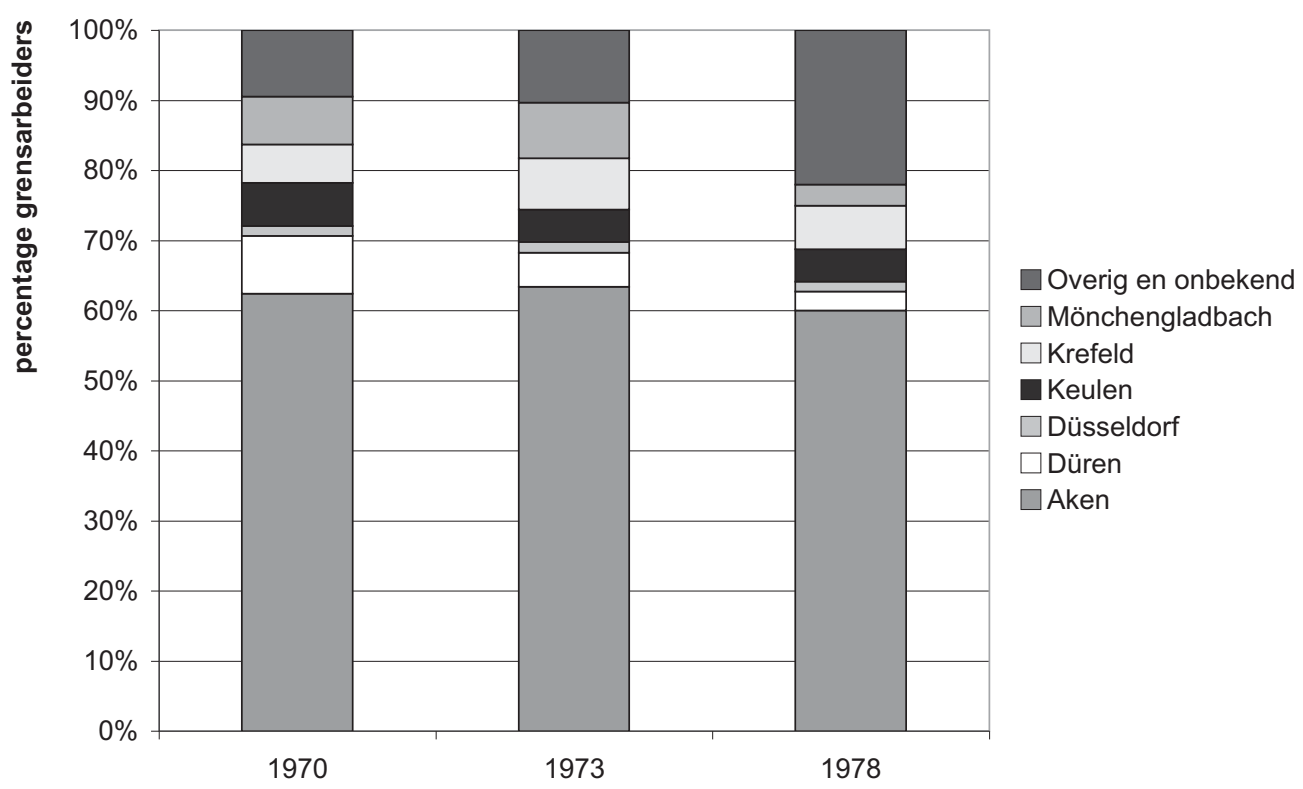

Door de crisis in en de beëindiging van de mijnbouw en de daaropvolgende problematische herstructurering was er een heel reservoir lager opgeleide mannelijke mijnarbeiders beschikbaar, dat zeer goed inzetbaar was in de Duitse nijverheid. Het merendeel van de grenspendelaars uit dit 'expulsiegebied' ${ }^{76}$ werkte dan ook als handarbeider in de bouw en de metaalindustrie. In 1971 behoorde 9o procent van de mannelijke pendelaars uit de Oostelijke Mijnstreek tot de categorie 'arbeiders', terwijl de rest onder de noemer 'employés' en 'handels- en kantoorpersoneel' viel. ${ }^{77}$

Behalve de samenstelling van het arbeidsaanbod in de Oostelijke Mijnstreek verklaart de geografische ligging de grote pendelstroom uit dit gebied..$^{8}$ Vrijwel de gehele Oostelijke Mijnstreek bevindt zich binnen een straal van twintig kilometer van de stad Aken, die in de jaren 1970 het belangrijkste werkgelegenheidscentrum voor de grensarbeiders was (zie figuur 4.5). ${ }^{79}$ Toentertijd werkte ruim tweederde van de grensarbeiders uit de Oostelijke Mijnstreek in het rayon Aken. Grensarbeiders uit het rayon Roermond werkten in groten getale in de op respectievelijk ongeveer 35 en 50 kilometer afstand gelegen rayons Mönchengladbach en Krefeld..$^{80}$

Volgens het DBA werkte in het begin van de jaren 1960 ongeveer 80 procent van de Limburgse grenspendelaars op korte afstand van de Duitse grens en pendelde de rest met name naar het Ruhrgebied. Het betrof hier weekpendelaars, grensarbeiders die één maal per week

75 Bron: CBS, Sociale Maandstatistiek 1970/11, 563-564; Idem, Sociale Maandstatistiek 1974/2, 6o-61; Idem, Sociale Maandstatistiek 1979/11, 862-864 (berekening SB).

76 DBA, Arbeidsmarktbeschrijuing 1969, 53; Idem, Arbeidsmarktbeschrijuing 1971, 53.

77 Hendriks et al., De gevolgen van de pendel op Duitsland, B25 (tabel B14).

78 Zie ook DBA, Arbeidsmarktbeschrijuing 1979, 69; Idem, Arbeidsmarktbeschrijuing 1980, 73.

79 Cijfers met betrekking tot de werkplaatsen van de pendelaars zijn pas vanaf 1970 beschikbaar (zie appendix A); zie ook Van den Berg et al., De grenspendel in Limburg, 71; Wolters, et al., Arbeid in beweging, 107.

8o CBS, Sociale Maandstatistiek 1970/11, 563-564; Idem, Sociale Maandstatistiek 1974/2, 60-61; Idem, Sociale Maandstatistiek 1979/11, 862864; Van den Berg et al., De grenspendel in Limburg, 70. 
naar huis terugkeerden. ${ }^{81}$ Van de respondenten van de NEI-enquête uit het begin van de jaren 1970 was slechts 4 procent actief als weekpendelaar. ${ }^{82}$ Uit berekeningen van het NEI bleek dat in die periode voor ruim de helft van de Zuid-Limburgse grensarbeiders de pendelafstand ook slechts 10 tot 12 kilometer bedroeg. De gemiddelde pendelafstand van alle Limburgse Duitslandgangers was 38,5 kilometer, een getal dat vooral omhoog werd gestuwd door degenen die in Noord-Limburg woonden. ${ }^{83}$

\section{Binnenlandse pendel versus grensoverschrijdende pendel}

Om na te gaan hoe de ontwikkeling van de pendelstroom naar Duitsland zich tot de grens verhield, dient tevens een vergelijking met de binnenlandse pendel te worden gemaakt. Indien de grens geen belemmering vormt, zou het aantal grenspendelaars vergelijkbaar met of groter dan het aantal binnenlandse pendelaars moeten zijn. ${ }^{84}$ Bij een vergelijking van de grenspendel met de binnenlandse pendel dient wel rekening te worden gehouden met de afstand die de pendelaars afleggen. Daarom is voor de binnenlandse pendel gebruik gemaakt van cijfers over de intergewestelijke pendel en niet de interrayonale pendel, die zich over kleinere afstanden voltrok. ${ }^{85}$

In de periode vanaf het einde van de jaren 1950 tot en met het einde van de jaren 1970 was het aantal binnenlandse intergewestelijke pendelaars over het algemeen groter dan het aantal Duitslandgangers (zie tabel 4.2).

\section{TABEL 4.2 AAN DEEL BINNEN LAN DSE EN DUITSLAN DPEN DELAARS WOONACHTIG} IN ZUID-LIMBURG NAAR WOONGEWEST, 1963, 1968, 1973, 1977

(\% VAN DE BEROEPSBEVOLKING). ${ }^{86}$

\begin{tabular}{lccllllll} 
Gewesten & $\mathbf{1 9 6 3}$ & & $\mathbf{1 9 6 8}$ & & $\mathbf{1 9 7 3}$ & & $\mathbf{1 9 7 7}$ & \\
& NL & D & NL & D & NL & D & NL & D \\
\hline Oostelijke Mijnstreek & 5 & 6 & 5 & 4 & 6 & 11 & 11 & 6 \\
Westelijke Mijnstreek & 8 & 2 & 8 & 1 & 6 & 4 & 12 & 1 \\
Maastricht & 10 & 3 & 7 & 2 & 7 & 3 & 8 & 1 \\
Roermond $^{87}$ & 12 & 3 & 7 & 2 & 7 & 4 & 10 & 2 \\
\hline Zuid-Limburg & 8 & 4 & 9 & 3 & 7 & 6 & 10 & 3
\end{tabular}

\footnotetext{
81 DBA, Arbeidsmarktbeschrijuing 1962, 39 .

82 Van den Berg et al., De grenspendel in Limburg, 92.

83 Ibidem, 71. Voor een indruk van de afstanden tussen de Zuid-Limburgse woongemeenten en de belangrijkste Duitse werkgemeenten: zie appendix D.

84 Hierbij kan nog worden aangetekend dat de omvang van de grenspendel vanuit Zuid-Limburg naar België in deze periode erg klein was, zowel in $1963,1968,1973$ als in 1978 tussen de 1.100 en de 1.200 personen, oftewel nog geen half procent van de beroepsbevolking. 85 Voor de gebiedsindeling: zie appendix A.

86 Onder NL staat het aantal binnenlandse pendelaars als percentage van de beroepsbevolking en onder D staat het aantal grensarbeiders dat in Duitsland werkte als percentage van de beroepsbevolking. Bronnen: DBA, Arbeidsmarktbeschrijving 1963, bijlage tabel 8 en 9; Idem, Arbeidsmarktbeschrijuing 1968, bijlage tabel 2 en 3; Idem Arbeidsmarktbeschrijuing 1973, bijlage tabel $2 a$ en $3 a$ (berekening: SB); cijfers over 1978 uit Derks, Limburgse pendel 1977-1985, 16) (voor de beroepsbevolking is daarbij gebruik gemaakt van ETIL, LSEV 1988, 64) (berekening: SB; halven zijn naar boven afgerond). In de eerder verschenen artikelen van mijn hand is overigens nog een vergelijking gemaakt met het percentage de interrayonale pendelaars binnen Zuid-Limburg, voor 1963 de grenspendel uit het rayon Vaals niet meegerekend, bij de grenspendel vanuit Roermond voor 1968 abusievelijk het percentage mannelijke pendelaars vermeld, en voor de Oostelijke Mijnstreek het gemiddelde van de percentages van de afzonderlijke rayons berekend, terwijl in dit hoofdstuk is uitgegaan van de totale pendel gedeeld door de totale beroepsbevolking. Bovendien betreft het in de artikelen de cijfers per rayon terwijl de term gewest wordt gebruikt (Bouwens, 'The Dynamics of Cross-Border Labour', 142-143; Idem, 'Werk in de marge?', 206-207).
} 
Alleen in de Oostelijke Mijnstreek overtrof het aandeel grensarbeiders het aandeel binnenlandse forensen. Dat gebeurde onder de uitzonderlijke omstandigheid dat de omvang en samenstelling van het vrijkomende arbeidsaanbod in dit gebied buitengewoon goed aansloten op de grote vraag naar arbeidskrachten in het Duitse grensgebied.

Ook binnen de Oostelijke Mijnstreek werd echter op grote schaal gependeld. Wanneer de verhouding tussen de grensoverschrijdende pendel en de binnenlandse pendel op een kleiner schaalniveau wordt bekeken door de interrayonale pendel als referentiepunt te nemen, blijkt de binnenlandse pendel vanuit de afzonderlijke rayons in de Oostelijke Mijnstreek vrijwel altijd groter dan de Duitslandpendel. ${ }^{88}$ Alleen in het rayon Kerkrade kende hij in 1973 een vergelijkbare omvang van ongeveer 16 procent. Onder de mannen werd wel iets meer naar Duitsland geforensd dan binnen Nederland: bijna 18 procent van de mannelijke beroepsbevolking werkte in Duitsland en bijna 17 procent werkte in andere delen van Nederland. ${ }^{89}$ Kerkrade ligt ongeveer even ver van Heerlen als van Aken verwijderd. Desondanks was het percentage grensarbeiders naar Duitsland in 1963 veel kleiner en in het piekjaar 1973 slechts een fractie groter dan het aandeel interrayonale binnenlandse forensen, terwijl de arbeidsmarktsituatie in Aken en omgeving beduidend gunstiger was dan die in Heerlen..$^{\circ}$

In dit verband is ook het sterk negatieve migratiesaldo van de Oostelijke Mijnstreek veelzeggend. In de tweede helft van de jaren 1960 en in de jaren 1970 gaven duizenden personen er de voorkeur aan de Oostelijke Mijnstreek te verlaten om in andere delen van Zuid-Limburg, maar ook in de Randstad en soms in het buitenland, een nieuw bestaan op te bouwen. Tussen 1965 en 1969 kenden de Oostelijke en de Westelijke Mijnstreek samen een negatief migratiesaldo van ruim 14.000 personen. Tussen 1970 en 1974 nam hun gezamenlijke vertrekoverschot af tot ongeveer 4.800 personen, dat gezien het positieve migratiesaldo in de Westelijke Mijnstreek volledig op het conto van de Oostelijke Mijnstreek kan worden geschreven. ${ }^{91}$

Ondanks de gunstige omstandigheden aan Duitse zijde van de grens bleef het aantal grensarbeiders dus betrekkelijk beperkt. Hoe is dit te verklaren? In contemporaine onderzoeken lag de nadruk op de beweegredenen van de grensarbeiders en was er weinig tot geen aandacht voor obstakels die het merendeel van de Zuid-Limburgers ervan weerhielden om in het naburige Duitse gebied te gaan werken. ${ }^{92}$ Uit de enquête die het NEI in 1972 afnam, kwam wel naar voren dat zowel Limburgse pendelaars als niet- en ex-pendelaars de kans op problemen rond uitkeringen bij ontslag en ziekte in Duitsland hoger schatten dan in Nederland. ${ }^{93}$ Toch bleken dergelijke risico's doorgaans geen doorslaggevende reden om niet in Duitsland te gaan werken. Opmerkelijk genoeg wisten of gaven veel van de door het NEI geënquêteerde nietpendelaars geen antwoord op de vraag waarom zij niet in Duitsland werkten. ${ }^{94}$ Mogelijk hadden zij deze optie nog niet in overweging genomen. De geografen Van Houtum en Van der

87 In de bronnen naar verwezen als 'Midden-Limburg'. Hier wordt de naam 'Roermond' aangehouden om verwarring rond het onderzoeksgebied dat 'Zuid-Limburg' (en het gebied tot en met Roermond bestrijkt) wordt genoemd te voorkomen.

88 Voor de indeling van Zuid-Limburg in arbeidsmarktgewesten en -rayons: zie appendix A.

89 Bron: DBA, Arbeidsmarktbeschrijuing 1973, bijlage tabel 2 en 17 (berekening:SB).

9o Dit is inclusief de pendel naar bestemmingen op grotere afstand dan Heerlen. In 1963 pendelden 4.405 personen vanuit Kerkrade naar andere Nederlandse rayons, terwijl 1.505 personen in Duitsland werkten. In 1973 werkten 3.170 personen uit Kerkrade in andere Nederlandse rayons en 3.200 in Duitsland (Bron: DBA, Arbeidsmarktbeschrijuing 1963, bijlage tabel 8 en 9; Idem, Arbeidsmarktbeschrijuing 1973, bijlage tabel $2 \mathrm{a}$ en tabel 3a).

91 Messing, Geschiedenis van de mijnsluiting in Limburg, 386, 473, 516.

Van den Berg et al., De grenspendel in Limburg; Hendriks et al., De gevolgen van de pendel op Duitsland; Derks, Pendel 1973-1979.

Hendriks et al., De gevolgen van de pendel op Duitsland, $\mathrm{D}_{3} 8$.

55 van de ondervraagde 142 niet-pendelaars (Van den Berg et al., De grenspendel in Limburg, 111-112). 
Velde spreken in dat geval van een threshold of indifference, ${ }^{95}$ die ervoor zorgt dat grensbewoners de mogelijkheid om over de grens te werken over het hoofd zien. Deze drempel vindt zijn wortels in de nationale socialisatie die ook grensbewoners ondergaan. Zij ontwikkelen zo een nationale habitus, waardoor ze zich primair op hun eigen land oriënteren en er een grote mentale afstand tot de arbeidsmarkt aan de andere kant van de grens bestaat, ook al bevindt deze zich geografisch gezien op een steenworp afstand. Op die manier blijft de arbeidsmarkt van het buurland buiten beeld..$^{6}$

De niet-pendelaars die wel antwoord gaven op de vraag waarom zij niet in Duitsland werkten, gaven aan dat ze in Nederland werk hadden en daarmee genoeg verdienden, dat ze het reizen naar Duitsland te vermoeiend vonden, en dat het huiselijk leven eronder zou lijden. ${ }^{97} \mathrm{Zo}-$ als we hebben gezien lag het loonniveau in Noordrijn-Westfalen op dat moment ongeveer een derde boven dat aan Nederlandse zijde van de grens. Verder bleek uit de enquête van het NEI dat de grensarbeiders dagelijks gemiddeld 45 minuten langer van huis waren dan degenen die in eigen land werkten..$^{9}$ Blijkbaar vormden de loonverschillen voor deze personen onvoldoende aanleiding om de grens over te steken en wat langer van huis te zijn.

Hoewel de door het NEI geënquêteerde grensarbeiders de hogere verdiensten in Duitsland veelal als hoofdreden noemden om in Duitsland te gaan werken, speelden de problematische arbeidsmarktomstandigheden in Zuid-Limburg eveneens een niet te verwaarlozen rol. Het NEI concludeerde dat de oriëntatie op de Duitse arbeidsmarkt ten tijde van de mijnsluitingen voortvloeide uit de onzekere situatie in Zuid-Limburg. ${ }^{99}$ Het DBA noemde grensarbeid een alternatief voor werkloosheid of migratie. ${ }^{100}$ Terwijl veel Zuid-Limburgers in eerste instantie mogelijk niet openstonden voor werk in Duitsland, zorgden de ongunstige regionale arbeidsmarktomstandigheden in combinatie met de wens in Zuid-Limburg te blijven wonen ervoor, dat een deel van de bevolking de gunstige omstandigheden in Duitsland wel opmerkte en benutte.

\section{MARginALE EN STABIELE PENDEL}

\section{Kwantitatieve parallellen}

In 1979 stelde het DBA dat de vermindering van het aantal Duitslandgangers langzamer verliep dan in de jaren daarvoor en voorspelde het dat 'een betrekkelijk stabiel patroon [...] in 1980 het beeld [zou] gaan bepalen'. ${ }^{101}$ In de jaren 1980 en de jaren 1990 vertoonde de pendelstroom inderdaad een minder schommelend verloop dan in de decennia ervoor. Dat ging samen met een gelijksoortige kwantitatieve ontwikkeling van de arbeidsmarkten aan weerszijden van de grens. Zuid-Limburg en het aangrenzende Duitse gebied gingen in de eerste

\footnotetext{
95 Letterlijk vertaald: 'drempel van onverschilligheid'.

96 Van der Velde en Van Houtum, 'De-politicizing labour market indifference', 47-50; Van Houtum en Van der Velde, 'The power of labour market immobility', 102-105. De term habitus is afkomstig van de socioloog Bourdieu (Outline of a theory of practice, 78-79). Vgl. Boutillier et al. die stellen dat Europeanen niet spontaan op zoek gaan naar werk in een andere Europese lidstaat (Frontaliers du Nord, 211).

97 Van den Berg et al., De grenspendel in Limburg, 100, 111-112 (de laatste tabellen betreffen uitsluitend mannen).

98 Hendriks et al., De gevolgen van de pendel op Duitsland, D21-22; slechts een beperkt deel van de pendelaars bleek door de week in Duitsland te verblijven: maar zo'n 4 tot 5 procent van de respondenten van het NEI (Van den Berg et al., De grenspendel in Limburg, 92-93; zie ook LD, 2-1-1972). Ongeveer tien jaar eerder werd het percentage Limburgse weekpendelaars op 20 tot 25 procent geschat (DNL, 4-3-1961; LD, 9-11-1961).

99 Van den Berg et al., De grenspendel in Limburg, 107; Hendriks et al., De gevolgen van de pendel op Duitsland, 19, 28-29.

100 DBA, Arbeidsmarktbeschrijuing 1972, 57.

101 Idem, Arbeidsmarktbeschrijuing 1979, 68
} 
helft van de jaren 1980 gebukt onder de aanhoudende economische depressie, die in deze periode haar hoogtepunt bereikte. ${ }^{102}$ Het Ruhrgebied, waar honderdduizenden arbeidsplaatsen verdwenen in de zware industrie en de mijnbouw, behoorde tot de ergst getroffen gebieden van Duitsland. Ook de Regio Aken had het zwaar te verduren. Er verdwenen duizenden banen in de mijnbouw, de traditionele industrie en de bouwnijverheid. ${ }^{103}$ Verder bleef de groei van de werkgelegenheid in andere bedrijfstakken achter bij die van de beroepsbevolking, waardoor het werkloosheidspercentage bleef stijgen. In 1982 kende het rayon Aken het hoogste werkloosheidspercentage van de deelstaat Noordrijn-Westfalen. ${ }^{104}$ Desondanks stak de werkloosheid in de Regio Aken nog gunstig af bij die in Zuid-Limburg. In 1985 lag het aandeel werklozen in de Regio Aken op ruim 8 procent, terwijl Zuid-Limburg bijna 13 procent werklozen telde. ${ }^{105}$ Behalve met de algemene economische crisis kampte de arbeidsmarkt aan Nederlandse zijde van de grens nog met de naweeën van de mijnsluitingen en de maar ten dele gelukte herstructurering. De pendelaars die werkloos uit Duitsland terugkeerden, deden hier nog een schepje bovenop. Vooral bouwvakarbeiders en, in iets mindere mate, metaalbewerkers zaten zonder werk. In het midden van de jaren 1980 begon de situatie te verbeteren. Het aantal werklozen nam af. ${ }^{106}$ Ook in het Duitse grensgebied daalde de werkloosheid, zij het wat langzamer. ${ }^{107}$ De vooruitzichten waren dus betrekkelijk gunstig toen in 1987 werd besloten de overgebleven steenkolenmijnen in de Regio Aken te ontmantelen. ${ }^{108}$

Toen Zuid-Limburg en de Regio Aken in de jaren 1980 een vrij analoge werkgelegenheidsontwikkeling vertoonden, stabiliseerde het aantal Duitslandgangers op een niveau van ongeveer 6.500 personen. Zodra de situaties in Zuid-Limburg en het Duitse grensgebied in de jaren 1990 weer enigszins uiteen gingen lopen, begon het aantal grensarbeiders uit Zuid-Limburg opnieuw toe te nemen.

De Duitse eenwording van 1990 bracht in eerste instantie een toenemende vraag naar WestDuitse producten met zich mee. Daardoor maakten bedrijfstakken als de papier- en de voedingsmiddelenindustrie een opleving door. Het aantal arbeidsplaatsen in de Regio Aken steeg met ongeveer 7 procent. ${ }^{109}$ Toen in 1992 de grootste steenkolenmijn in dit gebied haar poorten sloot, was het dankzij de werkgelegenheidsgroei mogelijk om alle voormalige mijnwerkers aan een nieuwe baan te helpen. ${ }^{110}$ In tegenstelling tot het aangrenzende Duitse gebied bevond Zuid-Limburg zich in het begin van de jaren 1990 in een conjunctureel dal. ${ }^{111}$ Tegelijkertijd lagen de Duitse lonen nog steeds boven de Nederlandse. In 1990 overtroffen de brutolonen voor 'arbeiders' en 'employés' in de nijverheid van de Duitse deelstaat Noordrijn-Westfalen die in Nederland met respectievelijk ongeveer 20 tot 30 procent. ${ }^{12}$ Onder deze omstandigheden liet de pendelstroom opnieuw een lichte aanwas zien. Met de recessie van 1993 kwamen de structurele problemen in de traditionele industrie aan Duitse zijde van de grens echter

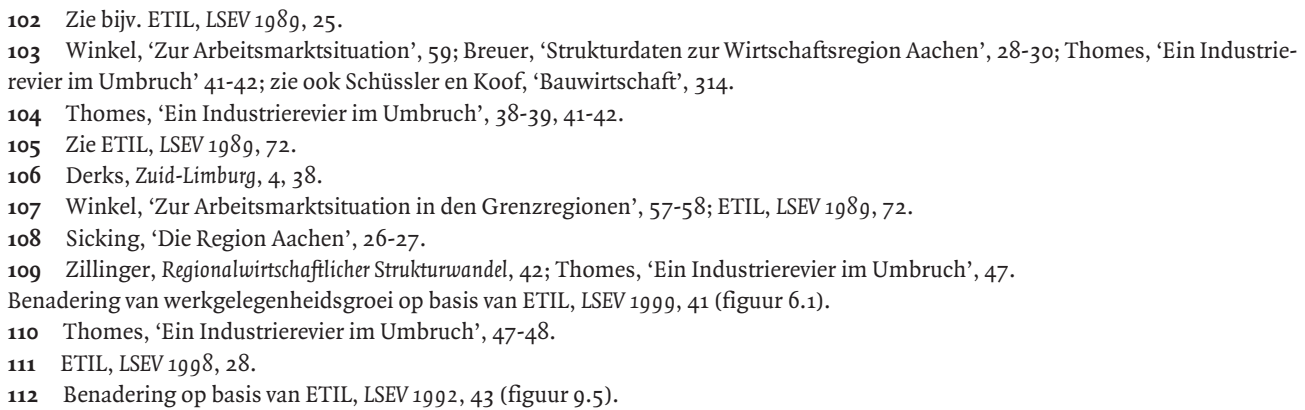


opnieuw aan het licht. Er vielen talloze ontslagen en de werkloosheid in de Regio Aken steeg tussen 1994 en 1997 met 15 procent. ${ }^{1{ }^{13}}$ Ondanks allerlei overheidsmaatregelen lukte het met de sluiting van de laatste steenkolenmijn in 1997 dan ook niet meer om voldoende vervangende werkgelegenheid te creëren. ${ }^{14}$

Sinds de jaren 1970 maakten de arbeidsmarkten aan weerszijden van de grens een herstructurering door. Terwijl de werkgelegenheid in traditionele industrie taande, won de dienstensector aan zowel Nederlandse als Duitse zijde van de grens aan belang. In de jaren 1970 had nog zo'n tweederde van de werkzame beroepsbevolking in de Regio Aken een productieberoep. Dit aandeel nam vervolgens sterk af. ${ }^{115}$ In de tweede helft van de jaren 1980 kon een groot deel van de werkgelegenheidsgroei op het conto van de zakelijke en overige dienstverlening worden geschreven. ${ }^{116}$ In Zuid-Limburg was het aantal arbeidsplaatsen in de dienstverlening onder meer toegenomen door de overplaatsing van een aantal rijksdiensten, zoals het Algemeen Burgerlijk Pensioenfonds (ABP), de Belastingdienst en het Centraal Bureau voor de Statistiek (CBS) naar Heerlen. Daarnaast groeide de werkgelegenheid in de commerciële dienstverlening. ${ }^{117}$ In de jaren 1990 bestond ongeveer tweederde van de werkgelegenheid in Zuid-Limburg en 6o procent van de arbeidsplaatsen in de Regio Aken uit banen in de dienstverlening. ${ }^{118}$ In de Regio Aken trad bovendien een belangrijke wijziging op in de samenstelling van de werkgelegenheid in de nijverheidssector. Mede dankzij de aanwezigheid van kennisinstituten als de Rheinisch-Westfälische Technische Hochschule (RWTH) en een actief herstructureringsbeleid, ontwikkelde zich een groeiende hightechindustrie. De werkgelegenheid in de machinebouw, de elektronica-industrie en de informatie- en communicatietechnologie expandeerde. ${ }^{119}$ In de jaren 1990 zette dit een Nederlandse journalist er zelfs toe aan het gebied te betitelen als 'Duits Silicon Valley'. ${ }^{120}$ De werkgelegenheid in de hightechindustrie was in de jaren 1990 echter zowel qua omvang als qua samenstelling niet geschikt om de verloren arbeidsplaatsen te compenseren. ${ }^{121}$

In 1993 was het werkloosheidspercentage van de Regio Aken en dat van Zuid-Limburg vrijwel gelijk, respectievelijk 7,5 en 7,4 procent. In de jaren daarna ging de werkloosheid in Aken die in Zuid-Limburg langzaam verder overstijgen.122 De omvang van de pendelstroom groeide nog tot 1995 , toen hij een periodiek hoogtepunt bereikte van bijna 8.200 grensarbeiders. In het midden van de jaren 1990 begon de arbeidsmarktsituatie in Zuid-Limburg aanzienlijk te verbeteren. De werkloosheid zakte tot iets minder dan 4 procent in 2000 . Tegelijkertijd zette de stijging van de werkloosheid in de Regio Aken door om in 2000 op ruim 9 procent uit te komen. ${ }^{123}$ In 2001 nam de werkloosheid in dit gebied weer af tot iets meer dan 6,5 procent. ZuidLimburg telde dat jaar slechts 3 procent werklozen. ${ }^{124}$ Onder deze condities nam het aantal

113 Thomes, 'Ein Industrierevier im Umbruch', 49; ETIL, LSEV 1998, 46.

114 Sicking, 'Die Region Aachen', 27-32; Thomes, 'Ein Industrierevier im Umbruch', 50.

115 Thomes, 'Ein Industrierevier im Umbruch', 35, 41-42.

116 Inclusief de overheid; ETIL, LSEV 1991, 40. Met ingang van de jaren 1980 werd de dienstverlening in heel Noordrijn-Westfalen (met name in Essen, Keulen en Düsseldorf) steeds dominanter (Zillinger, Regionalwirtschaftlicher Strukturwandel, 64-65, 72).

117 Messing, Geschiedenis van de mijnsluiting, 1988; ETIL, LSEV 1987, 52 (tabel 7.1); Idem, LSEV 1990, 29.

118 ETIL, LSEV 1993, 45; Idem, LSEV 1997, 33. Het betreft hier het RBA-gebied Zuid-Limburg (voor de gebiedsindeling: zie appendix A).

119 Sicking, 'Die Region Aachen', 27-30; zie ook Eschweiler und Indetzki, 'Wirtschaftsraum Aachen'.

120 Zie verwijzing naar De Raat, 'Keizersstad wordt Duits Silicon Valley' uit NRC Handelsblad, 5-7-1994 in Eschweiler, en Indetzki,

'Wirtschaftsraum Aachen', 171.

121 Thomes, 'Ein Industrierevier im Umbruch', 49-50.

122 Uitzondering hierop vormde het jaar 1995 waarin het werkloosheidspercentage van de Regio Aken licht daalde tot 8,1 procent, terwijl dat van Zuid-Limburg steeg tot 8,6 procent (ETIL, LSEV 1998, 69). Het betreft hier het RBA-gebied Zuid-Limburg.

123 ETIL, LSEV 1998 ,47; Idem, Limburg in Beeld 2001, 103.

124 Idem, Limburg in Beeld 2002, 49. Het betreft hier het RBA-gebied Zuid-Limburg. 
pendelaars af tot een niveau van 6.350 personen in 2001. Parallel daaraan steeg het aantal Duitse pendelaars dat in Zuid-Limburg werkte van bijna 200 in 1995 tot ruim 1.200 personen in 2001. ${ }^{125}$

Vergeleken met de periode vanaf het einde van de jaren 1950 tot en met het einde van de jaren 1970 kende de ontwikkeling van de pendelstroom vanuit Zuid-Limburg naar Duitsland in de jaren 1980 en 1990 dus een veel stabieler verloop. De omvang van de grenspendel bleef steken rond het niveau dat hij ten tijde van de recessie in 1966 en 1967 had bereikt. Hieruit kan evenwel niet worden geconcludeerd dat de arbeidsmobiliteit een vaste minimumomvang had aangenomen. Een toenemend aandeel grensarbeiders was namelijk van Duitse herkomst. Vanwege de gunstige woningmarkt migreerden er sinds de jaren 1980 steeds meer Duitse grensbewoners naar Nederland, terwijl zij hun baan in Duitsland aanhielden. Er was dus geen sprake van arbeidsmobiliteit, maar van verhuismobiliteit. Daarom wordt er ook wel van 'a-typische grensarbeiders' gesproken. ${ }^{126}$ Het negatieve migratiesaldo van Zuid-Limburg ten opzichte van Duitsland nam tussen 1987 en 1993 toe van ruim 200 tot meer dan 1.200 personen. ${ }^{127}$ In 1994 woonden er bijna 20.000 Duitsers in de provincie Limburg en vormden zij bijna 2 procent van de bevolking. ${ }^{128}$ In 1981 maakten de Duitse migranten bijna éénderde deel uit van het totale aantal in Nederland woonachtige Duitslandgangers. Elf jaar later was meer dan de helft van de 'Nederlandse' grensarbeiders in Noordrijn-Westfalen van Duitse herkomst. In de daaropvolgende jaren liep het aandeel 'a-typische grensarbeiders' vanuit Nederland naar Noordrijn-Westfalen wat terug tot iets minder dan de helft van alle grenspendelaars. ${ }^{129}$ Over het algemeen kan dus worden geconcludeerd dat de grensoverschrijdende arbeidsmobiliteit in de jaren 1980 en 1990 nog marginaler was dan de cijfers laten zien. De geografe Soutif wijst er in dit verband zelfs op dat emigratie de enige oorzaak voor de groei van de pendelstroom dreigt te worden. ${ }^{130}$

\section{Herstructurering}

De kwantitatieve parallellen tussen de vraag naar en het aanbod van arbeidskrachten aan weerszijden van de grens vielen samen met een beperktere aansluiting in kwalitatief opzicht. Door de herstructurering van de vraag gingen grensgerelateerde belemmeringen bovendien een belangrijkere rol spelen.

De verdeling naar bedrijfstak

Zoals we zagen, vertoonde de werkgelegenheidsstructuur in Noordrijn-Westfalen en ZuidLimburg in de jaren 1980 en 1990 veel gelijkenis. Iets minder dan tweederde van de arbeidsplaatsen bestond uit banen in de dienstverlening en ongeveer een derde uit banen in de nij-

125 CBS, Sociaal-Economische Maandstatistiek 1996/5, 46; http://statline.cbs.nl/Stat/Web/start.asp?LA=nl\&DM=SLN\&lp=Search/Search. Vgl. de situatie aan de Frans-Belgische grens waar het aantal Belgische grenspendelaars in de jaren 196o begon te dalen en het aantal Franse grensarbeiders in de jaren 1970 ging groeien. In 1998 en 1999 oversteeg het aantal Franse grenspendelaars het aantal Belgische pendelaars (Boutillier et al., Frontaliers du Nord, 153, 158, 174).

126 Zie TaskForce Grensarbeiders in de Euregio Maas-Rijn, zie http://www.emr-taskforce.org/nl.news.html

127 Wolters et al., Arbeid in beweging, 170-171.

128 Creemers, Grensoverschrijdende migratie en pendel, 15.

129 CBS Sociaal-economische Maandstatistiek 1985/12, 16; Bundesanstalt für Arbeit Landesarbeitsamt Nordrhein-Westfalen (LAANRW), Pendler in Nordrhein-Westfalen, 11. Vgl. de pendelstroom vanuit België naar Frankrijk die reeds in 1989 voor iets meer dan de helft uit Fransen bestond die vanwege het gunstigere belastingklimaat naar België waren gemigreerd, maar in Frankrijk waren blijven werken (Boutillier et al., Frontaliers du Nord, 154, 158).

130 Soutif, L'intégration européenne, 183. 


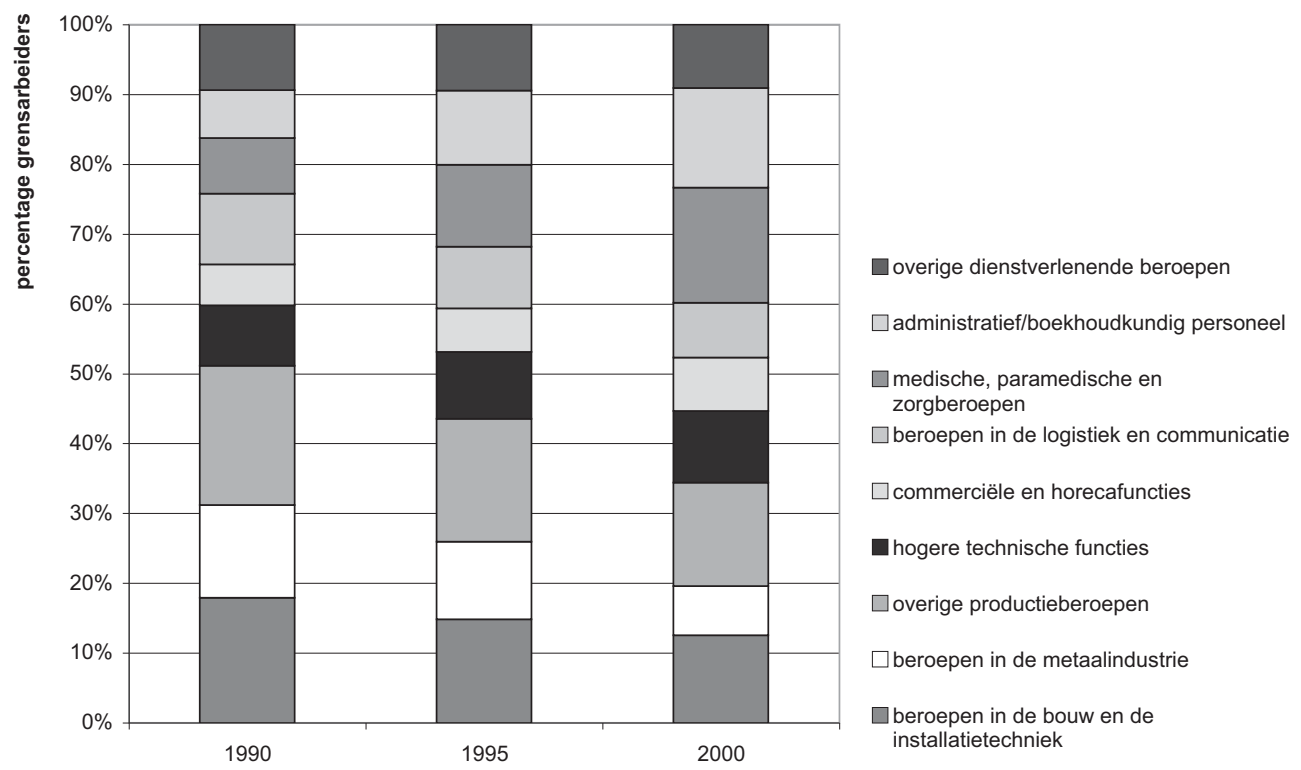

verheid. In de Regio Aken was het aandeel arbeidsplaatsen in de nijverheidssector iets groter, waarschijnlijk door de sterk vertegenwoordigde hightechindustrie. In 2001 kampte deze regio met een tekort aan hoger opgeleid technisch personeel (vooral informatici) en een overschot aan lager opgeleid technisch personeel. In Zuid-Limburg bestond er een evenwicht tussen de vraag naar en het aanbod van technisch personeel. Tegelijkertijd kenden zowel ZuidLimburg en de Regio Aken alsook Krefeld en Mönchengladbach een tekort aan medisch en paramedisch personeel. ${ }^{132}$

De herstructurering van de werkgelegenheid ging hand in hand met een veranderende samenstelling van de pendelstroom vanuit Nederland naar de Regio Aken. De grensarbeiders bleven nog enige tijd oververtegenwoordigd in de productieve beroepen. ${ }^{133}$ Terwijl rond 1990 ongeveer een derde van de werkgelegenheid in Zuid-Limburg en circa 40 procent van de werkgelegenheid in de Regio Aken uit arbeidsplaatsen in de nijverheid bestond, verdiende in 1990 nog iets meer dan de helft van de Nederlandse grensarbeiders in de Regio Aken zijn of haar brood in die sector (zie figuur 4.6). ${ }^{134}$ In 2000 was nog maar ongeveer een derde van de pendelaars in productieve beroepen werkzaam, wat nagenoeg overeenkomt met de algemene werkgelegenheidsstructuur in Zuid-Limburg en Aken. De dienstverlenende beroepen, waarin nu iets meer dan de helft van de grensarbeiders actief was, hadden de dominante positie van de

131 Bron: LAA-NRW (cijfers ontvangen via mail LAA-NRW, 28-7-2003). De categorie 'overig' is achterwege gelaten, omdat deze steeds een minimaal aantal grensarbeiders betreft. Bovendien betreffen deze cijfers uitsluitend de Regio Aken en worden de werkgelegenheidscentra Mönchengladbach en Krefeld dus niet vermeld.

132 Op basis van knelpuntindicatoren (mate waarin de openstaande vraag kan worden opgevuld door het plaatselijke aanbod van werklozen die minder dan drie maanden werkloos zijn) in Van Camp et al., Naar de arbeidsmarkt zonder grenzen, 37-39, 64, 142-152; Van Camp en Sieben, 'Naar de arbeidsmarkt zonder grenzen?', 56-62.

133 Dit was ook in andere Europese grensgebieden het geval (Soutif, L'intégration Européenne, 297).

134 In de LSEV staan geen cijfers over de werkgelegenheidsstructuur in de Regio Aken in 1990, maar wel over 1989 en 1991 (ETIL, LSEV 1992, 39; Idem, LSEV 1993, 45). 
productieberoepen overgenomen. Ook in die zin kan er dus niet van een harde kern van grensarbeiders worden gesproken. De dienstverlening is minder gevoelig voor conjuncturele ontwikkelingen dan de bouw, wat het verschil in fluctuatie van het aantal grensarbeiders met de decennia ervoor kan verklaren. Opvallend is dat het absolute aantal grensarbeiders in de dienstensector in de tweede helft van de jaren 1990 nog toenam, terwijl het totale aantal pendelaars kromp. Dit is grotendeels toe te schrijven aan de stijging van het aantal grensarbeiders in de zorg.

Met de veranderende structuur van de werkgelegenheid wijzigden ook de benodigde competenties. Veel functies in de dienstverlening en de hightechindustrie vergen een hoger opleidingsniveau dan functies in de nijverheid. Een goede opleiding werd aldus steeds meer een vereiste om in het Duitse grensgebied een baan te vinden. Dat verklaart het hoge aandeel laagof ongeschoolden onder de werklozen in de Regio Aken, dat in het begin van de jaren 1990 net geen 90 procent bedroeg. ${ }^{135}$ Ook in Zuid-Limburg waren de werklozen veelal laaggeschoold: in het midden van de jaren 1990 had tweederde van hen alleen een lagere opleiding had genoten, dat wil zeggen basisonderwijs eventueel aangevuld met een lagere beroepsopleiding. ${ }^{136}$ Het opleidingsniveau van de werkzame beroepsbevolking lag zowel in Zuid-Limburg als de Regio Aken hoger. ${ }^{137}$ In de jaren 1990 steeg ook het opleidingsniveau van de grensarbeiders licht. Het aandeel Nederlandse pendelaars met uitsluitend basisonderwijs dat in NoordrijnWestfalen werkte, daalde tussen 1990 en 2000 van 26 naar 18 procent. Tegelijkertijd groeide het aandeel hoog opgeleide grensarbeiders van 4 tot 7 procent. Het gros van de grensarbeiders had een lagere of middelbare beroepsopleiding afgerond. De stijging van het opleidingsniveau uitte zich eveneens in de veranderende functiegroepen waarin de grensarbeiders werkten. Het aandeel 'arbeiders' kromp van ruim tweederde in 1990 tot iets minder dan de helft in 2000, toen het contingent 'employés' het aandeel 'arbeiders' ging overtreffen. ${ }^{13^{8}}$ Daarmee was grensarbeid niet langer vrijwel uitsluitend 'een blue-collar aangelegenheid'. ${ }^{139}$

Het toenemende belang van een goede opleiding makte bovendien dat verschillen tussen de nationale onderwijssystemen in de jaren 1980 en 1990 een grotere rol gingen spelen dan in de decennia daarvoor. In de loop der jaren hebben Europese autoriteiten diverse maatregelen genomen om problemen op dit gebied aan te pakken, bijvoorbeeld via de erkenning van diploma's. ${ }^{140}$ Desondanks ervoeren Nederlandse hoger opgeleiden de erkenning van diploma's aan het einde van de jaren 1990 nog steeds als problematisch. ${ }^{141}$ Diverse medische en paramedische beroepsgroepen, zoals fysiotherapeuten en logopedisten, vormden hierop een uitzondering. Nederlandse opleidingen op dit gebied kenden een hoger niveau en genoten daardoor veel aanzien in Duitsland. ${ }^{142}$

135 Zij hadden een betriebliche Ausbildung gevolgd (Wolters et al., Arbeid in beweging, 76)

136 Lager of basisonderwijs, Lagere Beroepsopleiding of MAVO (nu: VMBO) (Wolters et al., Arbeid in beweging, 75, 164) (het betreft hier het RBA-gebied Zuid-Limburg).

137 Ibidem, 143 (het betreft hier het RBA-gebied Zuid-Limburg).

138 Bundesanstalt für Arbeit Landesarbeitsamt Nordrhein-Westfalen (LAA-NRW), Pendler in Nordrhein-Westfalen, 11; Het is niet duidelijk hoe de verhouding tussen lager beroepsonderwijs en middelbaar beroepsonderwijs ligt.

139 Op basis van een onderzoek naar onder meer grensarbeid van en naar Midden-Limburg verwachtten de geografen Passchier en Van Amersfoort in het midden van de jaren 1980 dat grensarbeid vooral een 'blue collar aangelegenheid' zou blijven ('De sociale betekenis van de Nederlandse nationale grenzen', 125).

140 http://europa.eu.int/scadplus/printversion/en/cha/coooo3d.htm.

141 Janssen en De Gijsel, 'Do Dutch-German Euregional labour markets really exist?', 14-15.

142 Van Goethem en Doumen, Grensarbeid in de Euregio Maas-Rijn, 59; zie ook LD, 24-5-1994 en De Vries, 'Gewaardeerde indringers', 21-9-2002. 


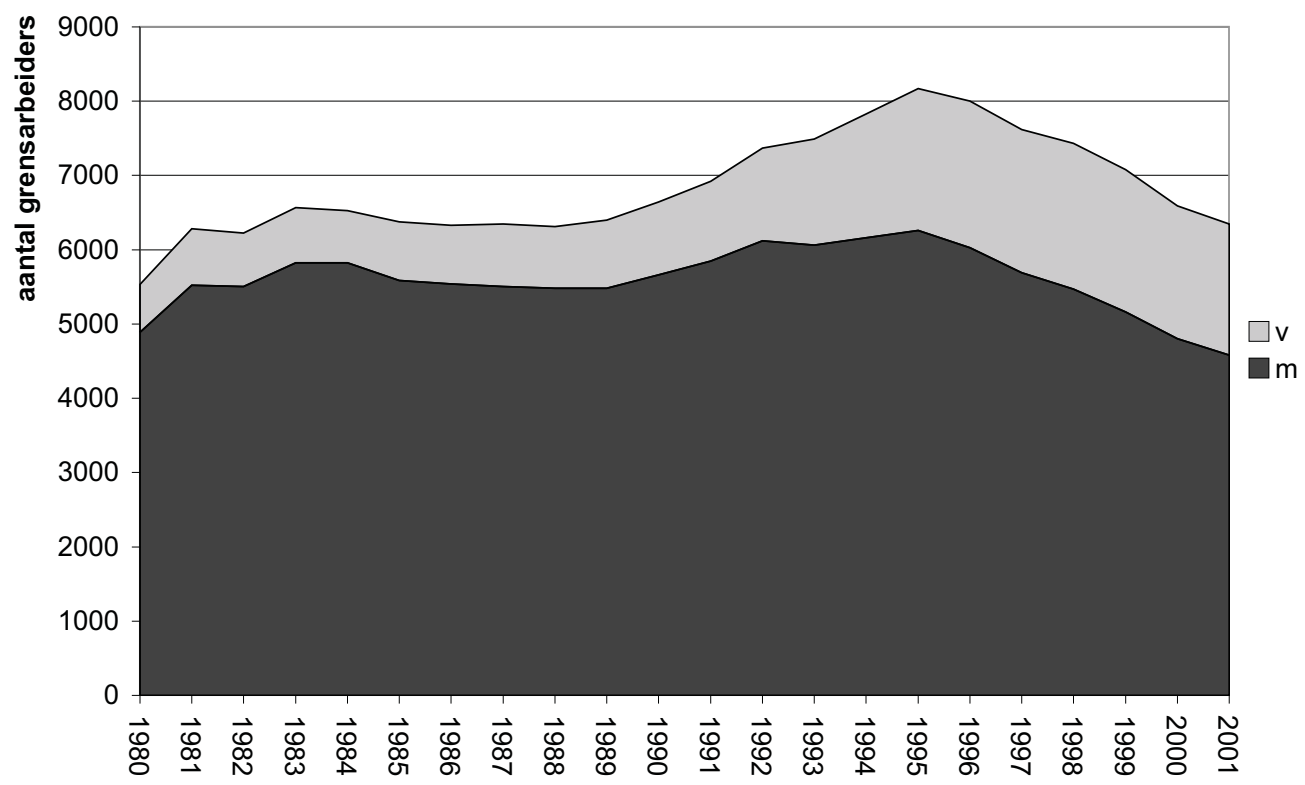

Ook met een passende opleiding kon het nog buitengewoon lastig zijn om over de grens te gaan werken. Beroepen in met name de dienstverlening vereisen dikwijls meer kennis van de nationale taal en wet- en regelgeving dan beroepen in de (traditionele) nijverheid. In de zorg is de communicatie met patiënten bijvoorbeeld erg belangrijk. Mede daardoor werd het werken over de grens bemoeilijkt. ${ }^{144}$ Als gevolg van de herstructurering van de werkgelegenheid gingen grensgerelateerde obstakels voor de pendel in de jaren 1980 en 1990 dus een prominentere rol spelen dan in de decennia ervoor.

\section{De verdeling naar geslacht en leeftijd}

Met de verandering van de beroepsmatige opbouw van de pendelstroom wijzigde tevens de samenstelling naar geslacht. Over het algemeen werken er meer vrouwen in de dienstverlening, en zeker in de zorg, dan in de nijverheidsector. Daarnaast gingen meer vrouwen buitenshuis werken. Dit correspondeert met de sterke groei van het aandeel vrouwelijke grensarbeiders van ruim een tiende in 1985 tot meer dan een kwart in 2000 (zie figuur 4.7). Tussen 1992 en 1995 nam het aantal vrouwen zelfs sterker toe dan het aantal mannen. ${ }^{145}$ Toch bleef het overgrote deel van de pendelstroom uit mannen bestaan. ${ }^{146}$

143 CBS, Sociale Maandstatistiek 1980-1983 en Sociaal-Economische Maandstatistiek 1984-2000; 2001: http://statline.cbs.nl/Stat/Web/ start.asp?LA=nl\&DM=SLN\&lp=Search/Search $(m=$ mannen; $v=$ vrouwen).

144 Ook formeel gezien kon het buitengewoon lastig zijn om in (bepaalde delen van) de publieke sector van een ander land te gaan werken, waardoor de mogelijkheden om te pendelen verder werden beperkt (De Gijsel et al,. 'Concepts and Issues', 11); de Verordening 1612/68 was ook niet van toepassing op de publieke dienstverlening (Verschueren, 'Arbeidsrechtelijk statuut van grensarbeiders', 54-55).

145 De feminisering van de pendelstroom sloot aan bij de Europese trend, maar bleef daar wel wat bij achter (Soutif, L'intégration européenne, bijv. p. 297).

146 Vgl. de Belgische pendelstroom naar Frankrijk die in 1998 voor bijna tweederde uit mannen bestond (Boutillier et al., Frontaliers du Nord, 158) 
De economen Wolters et al. verklaren het beperkte aantal vrouwelijke grensarbeiders uit de relatief lage arbeidsparticipatie van Nederlandse vrouwen. ${ }^{147} \mathrm{Zij}$ hadden vaker dan Duitse vrouwen deeltijdbanen. In 1993 werkte ongeveer een kwart van de werkzame Zuid-Limburgse beroepsbevolking minder dan 35 uur per week. In de Regio Aken werkte slechts 10 procent van de werkzame beroepsbevolking in deeltijd. ${ }^{14^{8}}$ Op dat moment had slechts 5 procent van de Nederlandse pendelaars in Noordrijn-Westfalen een deeltijdbaan. ${ }^{149}$ Andere verklaringen voor het kleine aantal vrouwelijke grenspendelaars zoeken Wolters et al. in de mogelijk beperkte geografische mobiliteit van vrouwen en niet nader omschreven andere behoeften van werkgevers. ${ }^{150}$

Net als in de decennia ervoor waren de vrouwelijke pendelaars in de jaren 1980 en 1990 veelal jonger dan de mannelijke (zie tabel 4.3). Wolters et al. schrijven dit toe aan het grote aantal jonge vrouwelijke arbeidskrachten in de Duitse zorg. ${ }^{151}$

\section{TABEl 4.3 Grensarbeiders Uit NEDERLAN D in DUITSLAN D NAAR LEEFTIJd EN} GESLACHT, 1983, 1988, 1993, $1998 .^{152}$

\begin{tabular}{|c|c|c|c|c|c|c|c|c|c|c|c|c|c|c|}
\hline & \multicolumn{2}{|c|}{$\begin{array}{l}<20 \mathrm{jr} \\
(\%)\end{array}$} & \multicolumn{2}{|c|}{$\begin{array}{l}20-24 \mathrm{jr} \\
(\%)\end{array}$} & \multicolumn{2}{|c|}{$\begin{array}{l}25-34 \mathrm{jr} \\
(\%)\end{array}$} & \multicolumn{2}{|c|}{$\begin{array}{l}35-44 \mathrm{jr} \\
(\%)\end{array}$} & \multicolumn{2}{|c|}{$\begin{array}{l}>44 \mathrm{jr} \\
(\%)\end{array}$} & \multicolumn{2}{|c|}{$\begin{array}{l}\text { totaal } \\
(\%)\end{array}$} & \multicolumn{2}{|l|}{$\begin{array}{l}\text { totaal } \\
\text { (abs.) }\end{array}$} \\
\hline & $\mathbf{m}$ & $\mathbf{v}$ & $\mathbf{m}$ & $\mathbf{v}$ & $\mathbf{m}$ & $\mathbf{v}$ & $\mathbf{m}$ & $\mathbf{v}$ & $\mathbf{m}$ & $\mathbf{v}$ & $m$ & $v$ & $m$ & $v$ \\
\hline 1983 & 1 & 3 & 8 & 20 & 29 & 33 & 40 & 24 & 22 & 20 & 100 & 100 & 10.259 & 1.277 \\
\hline 1988 & 1 & 3 & 6 & 21 & 23 & 33 & 40 & 24 & 29 & 18 & 100 & 100 & 9.730 & 1.440 \\
\hline 1993 & 1 & 2 & 8 & 20 & 25 & 42 & 30 & 20 & 36 & 16 & 100 & 100 & 11.800 & 2.790 \\
\hline 1998 & 1 & 1 & 4 & 11 & 25 & 44 & 26 & 23 & 44 & 20 & 100 & 100 & 10.810 & 4.040 \\
\hline
\end{tabular}

De in de jaren 1970 ingezette veroudering van de pendelaars zette in de jaren 1980 en 1990 door. Tussen 1983 en 1998 steeg het aandeel Nederlandse grensarbeiders (dus mannen én vrouwen) van 45 jaar of ouder van bijna 25 tot ongeveer 40 procent. ${ }^{153}$ De 'vergrijzing' van het pendelbestand wijst erop dat er, net als aan het einde van de jaren 1970, nog steeds weinig jonge grensarbeiders bij kwamen. ${ }^{154}$

De ruimtelijke spreiding

De concentratie van de grensarbeiders in de Oostelijke Mijnstreek bleef in de jaren 1980 en 1990 gehandhaafd (zie figuur 4.8). Dit gebied kende vergeleken met de rest van Zuid-Limburg nog altijd de meest problematische arbeidsmarktsituatie. ${ }^{155}$ Het werkloosheidspercentage bereikte er in 1984 een recordhoogte van ruim 20 procent om in 2001 uit te komen op circa 10 procent. ${ }^{156}$ De erfenis van de mijnsluitingen leek nog steeds niet helemaal verwerkt.

147 Wolters et al., Arbeid in beweging, 113.

148 Ibidem, 51, hoewel zij erop wijzen dat deze cijfers niet helemaal vergelijkbaar zijn, geven ze wel een indicatie van de verschillende mate waarin er deeltijd werd gewerkt.

149 Bundesanstalt für Arbeit Landesarbeitsamt Nordrhein-Westfalen (LAA-NRW), Pendler in Nordrhein-Westfalen, 11).

150 Wolters et al., Arbeid in beweging, 113.

151 Ibidem, 114.

152 Bronnen: CBS, Sociale Maandstatistiek 1983/8, 21; Idem, Sociaal-Economische Maandstatistiek 1989/7, 17; Idem, Sociaal-Economische Maandstatistiek 1994/3, 28; Idem, Sociaal-Economische Maandstatistiek 1998/12, 91; berekening: SB; percentages afgerond op hele getallen (halven naar boven afgerond). Door afrondingsverschillen komen de opgetelde weergegeven percentages niet altijd exact op 100 uit. Deze cijfers betreffen alle Nederlandse grensarbeiders, maar worden wel als indicatief beschouwd voor de grensarbeiders uit Zuid-Limburg. 153 CBS, Sociale Maandstatistiek 1983/8, 21; Idem, Sociaal-Economische Maandstatistiek 1998/12, 91 (berekening: SB).

154 Dit komt in grote lijnen overeen metde Europese ontwikkeling (Soutif, L'intégration européenne, 297). Vgl. ook devergrijzende Belgische pendelstroom naar Frankrijk die in 1998 voor meer dan de helft uit personen van 40 jaar en ouder bestond (Boutillier et al., Frontaliers du Nord, 158).

155 Derks, Zuid-Limburg, 23; Wolters et al, Arbeid in beweging, 71, 99, 105.

156 Derks, Zuid-Limburg, 39; overigens lag het werkloosheidspercentage van het arbeidsmarktgewest Maastricht van 1984 tot en met 1989 tijdelijk 1 tot 2 procent hoger dan dat van de Oostelijke Mijnstreek (zie ook ETIL, LSEV 1993, 70); ETIL, Limburg in Beeld 2001, 65. 


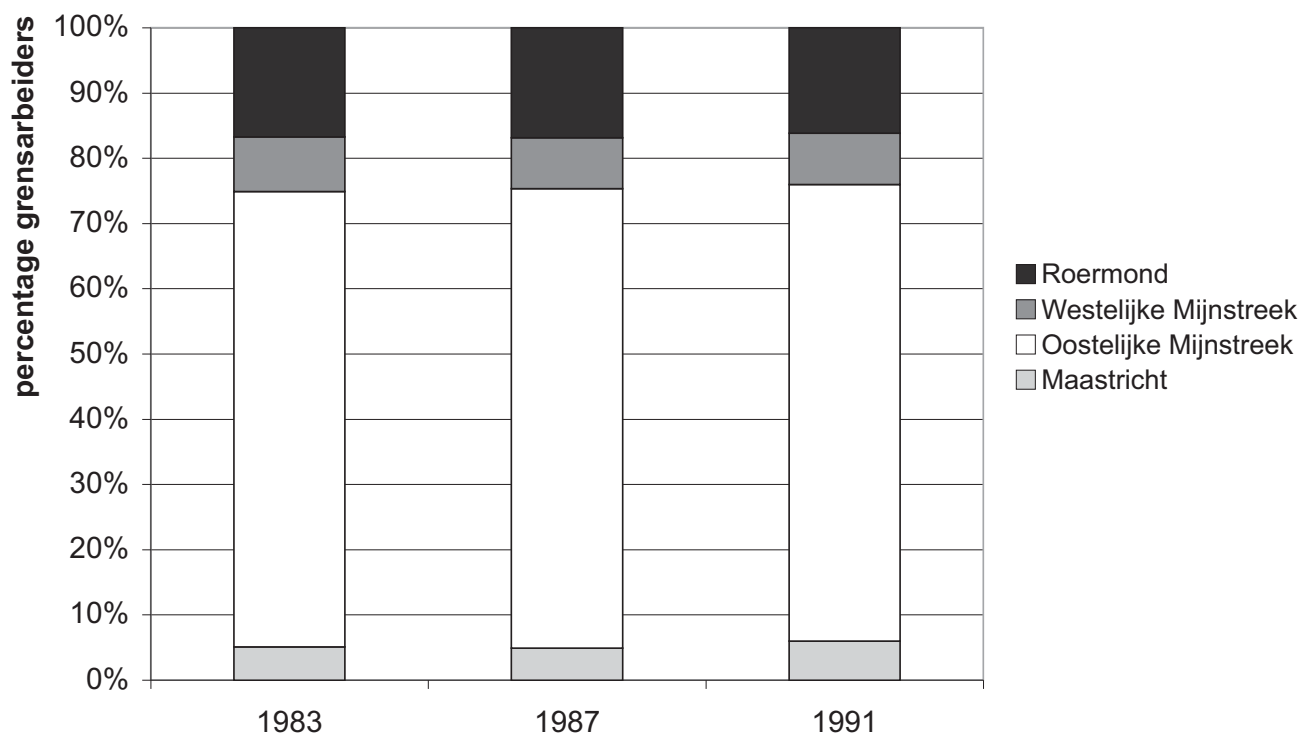

Zowel de binnenlandse als de grensoverschrijdende pendel vonden ook in de jaren 1980 en 1990 nauwelijks over grote afstanden plaats. Beide voltrokken zich doorgaans binnen een radius van twintig tot dertig kilometer. ${ }^{15^{8}}$ De stad Aken, die op ongeveer twintig kilometer van de Oostelijke Mijnstreek is gelegen, bleef een belangrijke werkplek voor de pendelaars (zie ook figuur 4.9). ${ }^{159}$ Deels vanwege de nabijheid van de stad Aken woonden er veel 'a-typische pendelaars' in de Oostelijke Mijnstreek. Vooral de grensgemeenten Vaals en Kerkrade waren populaire migratiebestemmingen. De bevolking van deze gemeenten bestond in de tweede helft van de jaren 1990 voor respectievelijk bijna 30 en 10 procent uit Duitsers. ${ }^{160}$

Hoewel de totale omvang van de pendelstroom stabiliseerde, de grensarbeiders ouder werden en nog steeds vooral afkomstig waren uit de Oostelijke Mijnstreek, veranderde de samenstelling van de pendelstroom wel. Het betrof vaker dan voorheen personen met dienstverlenende beroepen en Duitse immigranten die hun baan in Duitsland aanhielden. Er kan daarom niet worden gesproken van een harde kern van pendelaars.

157 Bron: ETIL, LAV 1991, 26 (dat de cijfers van het CBS gebruikt; overigens wijken de totalen in 1983 en 1991 licht af van de totalen berekend op basis van de cijfers zoals vermeld in de Sociaal-Economische en de Sociale Maandstatistiek van het CBS). Roermond betreft gewest Midden-Limburg. Vanaf 1991 zijn er geen cijfers over de pendel naar woongewest meer beschikbaar (zie ook appendix A). 158 Wolters et al., Arbeid in beweging, 106; Janssen en De Gijsel, 'Do Dutch-German Euregional labour markets really exist?', 6. Van weekpendel is geen sprake meer.

159 Vgl. Wolters et al., Arbeid in beweging, 99, 184; ook Keulen en Mönchengladbach boetten in aan belang als bestemming van de pendelstroom. Krefeld daarentegen won aan belang. Dit kan het resultaat zijn van een andere gebiedsindeling sinds 1988 (CBS, Sociaal-Economische Maandstatistiek 1988/3, 16). Dit neemt echter niet weg dat het relatieve belang van Aken als werkgebied van de grensarbeiders afneemt.

160 Creemers, Grensoverschrijdende migratie en pendel, 15 . 


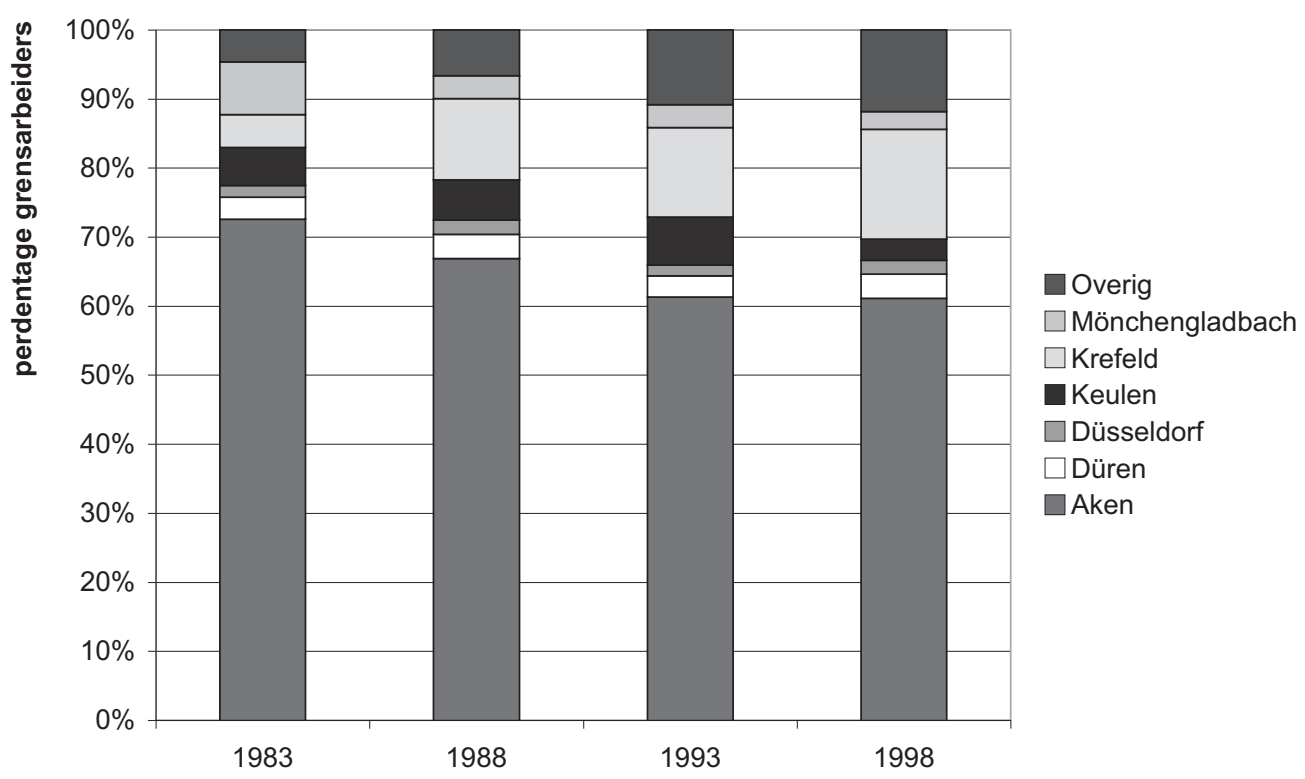

\section{Binnenlandse pendel versus grensoverschrijdende pendel}

De verschillen tussen de binnenlandse en de grensoverschrijdende pendel waren in de jaren 1980 en 1990 veel groter dan in de jaren 1960 en 1970 (zie tabel 4.4). ${ }^{162}$ In de Oostelijke Mijnstreek kwam het percentage pendelaars naar Duitsland opnieuw het dichtst bij het percentage binnenlandse forensen. Toch overtrof het dit bij lange na niet meer. Voor alle gewesten gold dat er veel meer naar andere Nederlandse gewesten dan naar Duitsland werd geforensd. ${ }^{163}$ Bovendien werd er vaak naar Nederlandse gewesten gependeld die op grotere afstanden lagen dan de belangrijkste Duitse werkgelegenheidscentra. Zo was Aken een belangrijker werkgelegenheidscentrum dan Heerlen of Maastricht en waren de Duitse lonen nog steeds hoger dan de Nederlandse, maar trokken de Nederlandse gewesten toch meer forensen. ${ }^{164}$

Aan Duitse zijde van de grens was het relatieve belang van de grenspendel eveneens beperkt. In 1993 bezetten Nederlandse grenspendelaars in de Regio Aken slechts 1 procent van alle arbeidsplaatsen. In de stad Aken ging het om 3 procent van alle arbeidsplaatsen. Binnenlandse forensen bezetten ruim driekwart van alle banen. In de grensgemeenten Herzogenrath

161 CBS, Sociale Maandstatistiek 1983/8, 21; Idem, Sociaal-Economische Maandstatistiek 1989/7, 17; Idem, Sociaal-Economische Maandstatistiek 1994/3, 32; Idem, Sociaal-Economische Maandstatistiek 1998/12, 96 .

162 Ook hier kan weer worden opgemerkt dat de omvang van de grenspendel vanuit Zuid-Limburg naar België in deze periode erg klein was. In 1981 werkten er ruim 1.200 Zuid-Limburgers in België, vier jaar later waren dat er 850 en in 1991 nog maar 780 ; het betrof daarmee nog steeds minder dan een half procent van de beroepsbevolking.

163 Ook Janssen vond een hoger aantal binnenlandse forensen dan grenspendelaars in zijn onderzoek naar grensoverschrijdende mobiliteit onder hoger opgeleiden aan de Nederlands-Duitse grens (Janssen, 'Borders and Labour-Market Integration', 55).

164 Wolters et al., Arbeid in beweging, 99. Waarschijnlijk migreerden er ook weinig Zuid-Limburgers naar Duitsland. In 1990 woonden er bijna 66.00o Nederlanders in Noordrijn-Westfalen, waarvan maar zo'n 2.00o in Kreis Aachen en iets meer dan 2.30o in de Kreisfreie Stadt Aachen (oftewel o,7 en 1,o procent van de lokale bevolking in deze gebieden) (Creemers, Grensoverschrijdende migratie en pendel, 19). 
en Gangelt was het aandeel Nederlandse pendelaars ook gering, in 1993 respectievelijk 7 en 6 procent. ${ }^{165}$

\section{TABEL 4.4 AAN DEEL BINNEN LAN DSE EN DUITSLAN DPEN DELAARS WOONACHTIG} IN ZUID-LIMBURG NAAR WOONGEWEST, 1981, 1985, 1991

(\% VAN DE BEROEPSBEVOLKING). ${ }^{160}$

\begin{tabular}{lllllll} 
Gewesten & $\mathbf{1 9 8 1}$ & & $\mathbf{1 9 8 5}$ & & $\mathbf{1 9 9 1}$ & \\
& NL & D & NL & D & NL & D \\
\hline Oostelijke Mijnstreek & 13 & 4 & 13 & 4 & 14 & 4 \\
Westelijke Mijnstreek & 14 & 1 & 18 & 1 & 18 & 1 \\
Maastricht & 14 & 0 & 11 & 0 & 12 & 0 \\
Roermond $^{167}$ & 11 & 2 & 11 & 2 & 12 & 1 \\
\hline Zuid-Limburg $^{13}$ & 13 & 3 & 13 & 2 & 14 & 2
\end{tabular}

In 2001 stelden de economen Van Camp et al. dat er 'allerlei belemmeringen [zijn] die ervoor zorgen dat er eerder mobiliteit optreedt op grotere afstanden binnen een land, dan op geringe afstand tussen landen' ${ }^{168}$ Uit diverse enquêtes uit de jaren 1990 blijkt dat verschillen in weten regelgeving en de beperkte beschikbaarheid van informatie over de arbeidsmarkt aan de andere kant van de grens, grenspendel in de weg kunnen staan. De herstructurering van de werkgelegenheid maakte bovendien dat het belang van een goede opleiding en kennis van de Duitse taal en wet- en regelgeving in de jaren 1980 en 1990 groter was dan in de jaren 1960 en 1970. Dit, en de beperkte vergelijkbaarheid van diploma's, zou het werken in Duitsland bemoeilijken. Daarnaast worden minder tastbare belemmeringen voor grensarbeid, in de vorm van cultuurverschillen en wederzijdse vooroordelen, genoemd. ${ }^{169}$

Al deze, zowel concrete als abstractere, hindernissen gaan evenwel pas spelen wanneer grensbewoners het buurland meenemen in hun zoekgedrag op de arbeidsmarkt. Dat was lang niet altijd het geval. Uit een enquête die de econoom Janssen aan het einde van de jaren 1990 onder Zuid-Limburgse hoger opgeleiden hield, kwam naar voren dat slechts 5 procent van hen in Duitsland naar werk zocht. ${ }^{170}$ Onderzoek dat deze econoom en de geografen Van Hou-

\footnotetext{
165 Wolters et al., Arbeid in beweging, 98-99.

166 Voor de jaren 1980 en 1990 zijn alleen regionaal uitgesplitste cijfers met betrekking tot het binnenlandse forensgedrag gevonden over de jaren 1981, 1985 en 1991. Bronnen: Cijfers binnenlandse en grensoverschrijdende pendel uit ETIL, LAV 1993, 33; cijfers beroepsbevolking 1981 en 1985 uit: Idem, LSEV 1988, 64 (cijfers afgerond op honderdtallen); cijfers beroepsbevolking 1991 uit Idem, LAV 1993, 29 (berekening: SB; halven zijn naar boven afgerond). De ETIL-cijfers met betrekking tot de grensarbeid wijken licht af van de op basis van de CBS-cijfers berekende aantallen. De percentages binnenlandse pendelaars wijken bovendien enigszins af van de percentages genoemd in de eerder verschenen artikelen van mijn hand (Bouwens, 'The Dynamics of Cross-Border Labour', 146; Idem, 'Werk in de marge?', 211-212) omdat het daar de intraregionale pendel betreft en voor de Oostelijke Mijnstreek abusievelijk het percentage intraregionale pendelaars uit de Westelijke Mijnstreek is vermeld. Bovendien wijkt het percentage grenspendelaars in Midden-Limburg (Roermond) af van het percentage zoals weergegeven in het artikel, omdat hier een andere bron is gebruikt voor de beroepsbevolking in Midden-Limburg (daar gebruikt: ETIL, LAV 1992, 24). Soutif verwijst in haar artikel ('Domicile-travail', 127) naar een vergelijking van de binnenlandse en de grensoverschrijdende pendel in de scriptie van Walpot. Zij stelt dat de binnenlandse pendel uit het gewest Oostelijke Mijnstreek in 1989 kleiner was dan de grenspendel naar Duitsland. De cijfers waarop zij deze constatering baseert, blijken echter niet helemaal vergelijkbaar te zijn. Zij gebruikt alleen cijfers over de pendel die zich binnen Zuid-Limburg voltrekt en stelt het aantal binnenlandse pendelaars gelijk aan het binnenlands pendelsaldo (De Euregio Maas-Rijn, 71-73).

167 In de bronnen naar verwezen als 'Midden-Limburg'. Hier wordt de naam 'Roermond' aangehouden om verwarring rond het onderzoeksgebied dat 'Zuid-Limburg' (en het gebied tot en met Roermond bestrijkt) wordt genoemd te voorkomen.

168 Van Camp et al., Naar de arbeidsmarkt zonder grenzen, 97.

169 Wolters et al., Arbeid in beweging, 120-124; Van Beek, Samenwerking?, 91-92; Soutif, 'Domicile-travail', 135; Janssen en De Gijsel,

'Do Dutch-German Euregional labour markets really exist?', 14-15.

170 Verwijzing naar Janssen in Van Camp et al., Naar de arbeidsmarkt zonder grenzen, 102.
} 
tum en Van der Velde enkele jaren later in Nijmegen en omgeving verrichtten, laat verder zien dat de Duitse arbeidsmarkt vaak een terra incognita was voor Nederlandse werkzoekenden. ${ }^{17}$ Aan het einde van de twintigste eeuw werd de threshold of indifference ten opzichte van Duitsland dus zelden overschreden. Daar was in Zuid-Limburg ook minder aanleiding toe dan in de decennia ervoor, toen de regionale omstandigheden problematisch waren en het aangrenzende Duitse gebied tegelijkertijd een buitengewoon voorspoedige ontwikkeling doormaakte.

\section{SLOT}

Uit de analyse van de dynamiek en diversiteit van de pendelstroom tussen 1958 en 2002 blijkt dat hij geen geleidelijke groei vertoonde, maar dat de Duitslandpendel sterk afhankelijk was van de verhouding tussen de sociaal-economische omstandigheden aan weerszijden van de grens. In de evolutie van de pendelstroom tussen 1958 en 2002 kunnen twee perioden worden onderscheiden, waarin hij een ander verloop en een andere samenstelling liet zien. Figuur 4.10 vat voor beide perioden de relatie tussen de ontwikkeling van de grenspendel en de sociaal-economische omstandigheden aan beide kanten van de grens samen.

\section{FIGUUR 4.10 VERSCHILLEN EN OVEREENKOMSTEN IN VRAAG EN AANBOD TUSSEN DE ARBEIDSMARKTEN IN ZUID-LIMBURG EN HET AANGRENZENDE DUITSE GEBIED PER PERIODE.}

\begin{tabular}{lcc} 
& eind jaren 1950 - eind jaren 1970 & jaren 1980-2001 \\
\hline kwantiteit & \multicolumn{1}{c}{$\neq$} & $\approx$ \\
kwaliteit & & $\approx$ \\
& $\rightarrow$ relatief veel Duitslandpendel & $->$ weinig Duitslandpendel \\
\hline & $\neq$ : verschillend & \\
& $\approx$ : vergelijkbaar
\end{tabular}

In de eerste periode, vanaf het einde van de jaren 1950 tot en met het einde van de jaren 1970, bereikte het aantal grensarbeiders naar Duitsland zijn naoorlogse hoogtepunt en overtrof hij in de Oostelijke Mijnstreek tijdelijk het aantal binnenlandse pendelaars. De ontwikkeling van de pendelstroom vertoonde een sterke fluctuatie. De relatief grote omvang van de Duitslandpendel was het resultaat van uitzonderlijke sociaal-economische omstandigheden. Tot en met 1973 maakten de arbeidsmarkten van Zuid-Limburg en het aangrenzende Duitse gebied in kwantitatief opzicht een sterk divergerende ontwikkeling door. Dit exceptionele verschil was onmiskenbaar verbonden met de aanwezigheid van de grens. De afwijkende nationale (sociaal-)economische regimes droegen bij aan de grote verschillen tussen de vraag naar en het aanbod van arbeidskrachten en de lonen aan Nederlandse en Duitse zijde van de grens. Hier zien we de paradox van de grens terug. Door het bestaan van de grens als scheidslijn vertoonden de arbeidsmarkten aan weerszijden van de grens een ongelijke ontwikkeling, die het aantrekkelijk maakte haar te overschrijden. Daardoor fungeerde zij tegelijkertijd als

171 Zij verrichtten in 2003 onderzoek in het grensgebied bij het Nederlandse Nijmegen en het Duitse Goch (Van der Velde et al., 'Job mobility in the Dutch-German regional labour market', 86-87). 
scheids- en als verbindingslijn. Juist doordat de gebieden aan weerszijden van de grens bij lange na geen geïntegreerde arbeidsmarkt vormden, werd er dus op relatief grote schaal naar Duitsland gependeld en was de grenspendel een schakel tussen beide arbeidsmarkten. Desondanks lijkt een deel van de beroepsbevolking ervan te zijn weerhouden om überhaupt stil te staan bij de mogelijkheid om te gaan pendelen. De problematische situatie in Zuid-Limburg en de wens om er te blijven wonen, makten dat anderen deze wel opmerkten en de kansen aan de Duitse zijde van de grens grepen.

Daarnaast sloot de omvangrijke vraag naar arbeidskrachten in het Duitse grensgebied in de eerste periode kwalitatief gezien bijzonder goed aan bij het grote aanbod van arbeidskrachten in met name de aan de grens gelegen Oostelijke Mijnstreek. Ten tijde van de crisis in en sluiting van de Zuid-Limburgse mijnbedrijven kwamen daar duizenden laag opgeleide mannelijke handarbeiders beschikbaar, die uitstekend inzetbaar waren in de expanderende Duitse bouw en industrie. Het grote aandeel bouwvakarbeiders was grotendeels verantwoordelijk voor de conjunctuurgevoeligheid van de pendelstroom.

Het jaar 1973 vormde een keerpunt. De eerste oliecrisis mondde uit in een economische depressie en deed de werkgelegenheid in Zuid-Limburg evenals het aangrenzende Duitse gebied drastisch krimpen. Dat ging gepaard met een dalend aantal grensarbeiders, vooral in de bouw en de industrie. Meestal konden zij ook in Zuid-Limburg geen werk vinden en raakten ze werkloos.

In de tweede periode, vanaf het begin van de jaren 1980 tot en met 2001, stabiliseerde het aantal grensarbeiders op een betrekkelijk laag niveau. Er werd beduidend minder over de grens geforensd dan in eigen land. Dit viel samen met een meer analoge werkgelegenheidsontwikkeling in Zuid-Limburg en het aangrenzende Duitse gebied. In de jaren 1990 ontstond er weer enige divergentie, die zich manifesteerde in een licht veranderende omvang van de pendelstroom. In vergelijking met de decennia ervoor was het aantal grensarbeiders in de jaren 1980 en 1990 echter bijzonder constant en zeer gering, zeker wanneer rekening wordt gehouden met het grote aandeel Duitse immigranten.

Met de herstructurering van de economie kreeg de dienstverlening in deze periode een dominante positie op de arbeidsmarkt in zowel het Nederlandse als het Duitse grensgebied. In de jaren 1990 waren steeds meer grensarbeiders in deze sector werkzaam. Werkgelegenheid in de dienstverlening is doorgaans minder conjunctuurgevoelig dan werkgelegenheid in de bouw, wat bijdroeg aan de stabielere ontwikkeling van de pendelstroom in de jaren 1980 en 1990. In de Regio Aken was verder de hightechindustrie in opmars. In vergelijking met de zware en traditionele industrie en de bouwnijverheid, bestaat er zowel in de dienstverlening als de hightechindustrie veelal meer vraag naar hoger opgeleide werknemers en kennis van de nationale taal en eventueel wet- en regelgeving. Het arbeidsaanbod in Zuid-Limburg sloot hier slecht op aan. Doordat de arbeidsmarktsituaties kwantitatief gezien meer gelijkenis vertoonden en de samenstelling van vraag en aanbod in Zuid-Limburg en het aangrenzende Duitse gebied niet meer aansloten, bleef het aantal grensarbeiders in deze periode erg bescheiden. Daarbij groeide het belang van belemmeringen die samenhingen met de aanwezigheid van de grens, zoals verschillen in wet- en regelgeving, maar ook mentale barrières.

Korres en het NEI stellen dat de grens respectievelijk tot in de jaren 1960 en in de eerste helft van de jaren 1970 nauwelijks enige rol van betekenis speelde op de arbeidsmarkt. In dit hoofdstuk is echter gebleken dat zij in de periode vanaf het einde van de jaren 1950 tot en met 2001 juist van wezenlijk belang was voor de ontwikkeling van de pendelstroom. Gedurende 
de eerste twee decennia was de paradox van de grens duidelijk herkenbaar. De ongelijke ontwikkelingen die de grens markeerde, maakten het aantrekkelijk haar te overschrijden. Toch bleef ook in deze periode het aantal grensarbeiders redelijk klein. Toen de arbeidsmarktsituaties aan weerszijden van de grens vanaf de jaren 1980 meer gelijkenis vertoonden en de vraag aan Duitse en het aanbod aan Nederlandse zijde van de grens minder op elkaar aansloten, werkte de aanwezigheid van de grens vooral belemmerend op de totstandkoming van grensarbeid. De relatie tussen de grens en de grenspendel was dus veranderlijk en mede afhankelijk van de sociaal-economische situatie. Op het ene moment kon de grens tegelijkertijd als scheidslijn en als brug fungeren, terwijl later andere aspecten van de grens domineerden en zij hoofdzakelijk een barrière vormde.

Europese maatregelen om het werken over grenzen te faciliteren hebben geen doorslaggevende invloed gehad op het verloop van de pendelstroom. Op basis van cijfermateriaal over grensarbeid in Europa in de jaren 1990 stelt de socioloog Schack dat Europees beleid gericht op economische convergentie niet tot meer grensoverschrijdende arbeidsmobiliteit zal leiden. Juist sterk afwijkende arbeidsmarktsituaties werken grensarbeid in de hand. ${ }^{172}$ Dat kan eveneens voor verschillen in sociale en fiscale wet- en regelgeving gelden. Indien de wettelijke kaders sterk van elkaar afwijken, kunnen zich ongelijke ontwikkelingen voordoen. Deze hoeven grensarbeid niet alleen te belemmeren, maar kunnen het ook aantrekkelijk maken de grens te overschrijden. Op grond van de casus van de Duitslandpendel vanuit Zuid-Limburg behoeft dit beeld wel enige nuancering. Kwantitatieve discrepanties in de werkgelegenheidsontwikkeling aan weerszijden van de grens stimuleerden grensarbeid weliswaar, maar vraag en aanbod dienden ook in kwalitatief opzicht aan te sluiten om grenspendel op relatief grote schaal te doen plaatsvinden. Dit laatste wordt bemoeilijkt wanneer de arbeidsmarkt vraagt om meer kennis van de nationale wet- en regelgeving en taal.

In hoofdstuk 5 wordt beschreven hoe er in de regionale publieke sfeer op de grenspendel werd gereageerd en in hoofdstuk 6 worden de vragen beantwoord waarom en hoe grensarbeiders grensgebonden belemmeringen om te gaan pendelen hebben overwonnen, en wat dit vervolgens impliceerde voor de betekenis van de grens in hun dagelijks leven.

172 Schack, 'Cross-border commuting and integration'. Zie ook Van Amersfoort en Passchier, 'De sociale betekenis van de Nederlandse nationale grenzen', 129; Werner, 'Beschäftigung von Grenzarbeitnehmern', 32; Vgl. Boutillier et al., Frontaliers du Nord, 171-173, 210-211. 


\title{
Hoofdstuk 5 \\ Tussen wens en werkelijkheid De herdefiniëring van 'het pendelprobleem' in de regionale publieke sfeer
}

\author{
'Pendelprobleem weegt zwaar op Limburg' (De Nieuwe Limburger, 29-4-1964) \\ 'Einde in zicht van de pendelproblematiek' (Limburgs Dagblad, 14-4-1988)
}

Getuige de bovenstaande krantenkoppen werd de grenspendel in de Limburgse pers zowel in de eerste helft van de jaren 1960 als aan het einde van de jaren 1980 als problematisch bestempeld. 'Het pendelprobleem' had op deze momenten echter een volkomen andere betekenis. De eerste kop verwijst naar moeilijkheden die de grenspendel op de Limburgse arbeidsmarkt zou veroorzaken. De tweede kop heeft betrekking op de financiële nadelen die (ex-)grensarbeiders van het pendelen ondervonden. Terwijl er steeds van een 'pendelprobleem' werd gesproken, kreeg dit begrip door de jaren heen een veranderende invulling. In dit hoofdstuk, dat de betekenis van de grenspendel in relatie tot de grens vanuit regionaal sociaal-politiek perspectief analyseert, wordt deze verschuiving beschreven. Daarbij zal duidelijk worden dat 'de pendelproblematiek' doorgaans geen eenduidige, maar een meervoudige betekenis had. Er bestonden meestal diverse definities van 'de pendelproblematiek' naast elkaar. Bovendien zal blijken dat de term 'pendelprobleem' weliswaar een normatieve connotatie had, maar dat hij lang niet altijd een afwijzing van de Duitslandpendel in zich droeg. Opiniemakers in (Zuid-)Limburg waren lange tijd tegen de grenspendel gekant, maar gingen hem sinds het einde van de jaren 1970 anders waarderen.

Grensarbeid toont de spanning tussen grensoverschrijdende en begrensde praktijken en oriëntaties die kenmerkend is voor het dagelijks leven in grensgebieden. De manier waarop daarmee in de regionale publieke sfeer werd omgegaan, is tekenend voor de positionering van (Zuid-)Limburg in relatie tot de nationale staat en biedt tevens zicht op de betekenis van de grens. De berichtgeving rond de grenspendel in de Limburgse pers handelde overwegend over de politiek-materiële dimensie van de grens. Achter de verslaglegging ging echter een veranderend betekeniskader met betrekking tot (Zuid-)Limburg als grensgebied schuil, dat samenhing met de sociaal-culturele dimensie van de grens. Uit de analyse van de regionale beeldvorming rond de Duitslandpendel zal blijken dat (Zuid-)Limburg aanvankelijk als perifeer, maar integraal onderdeel van de Nederlandse staat werd gezien, en later juist buiten de nationale, en in Europese, kaders werd geplaatst.

Aan de hand van een globale kwantitatieve en een uitgebreide kwalitatieve analyse van ruim 400 artikelen over de Duitslandpendel in de regionale dagbladen, wordt beschreven hoe de herwaardering van de Duitslandpendel gestalte kreeg en welke conceptie van (Zuid-)Limburg als grensgebied daarachter zat. ${ }^{1}$ In het kwantitatieve gedeelte wordt de algemene teneur ge-

1 Er is gebruik gemaakt van de twee Limburgse dagbladen (Dagblad De Limburger en Limburgs Dagblad en hun voorgangers) waarin veelal werd geschreven over de Duitslandpendel vanuit Limburg als geheel, in plaats van alleen uit het zuidelijk deel van de provincie. Indien dit niet het geval was, wordt expliciet van Zuid-Limburg gesproken. Het Limburgs(ch) Dagblad wordt afgekort als LD, De Nieuwe Limburger als DNL, De Limburger als DL en Dagblad De Limburger als DDL. Voor meer over de steekproef en de uitvoering van de analyse: zie appendix B. 


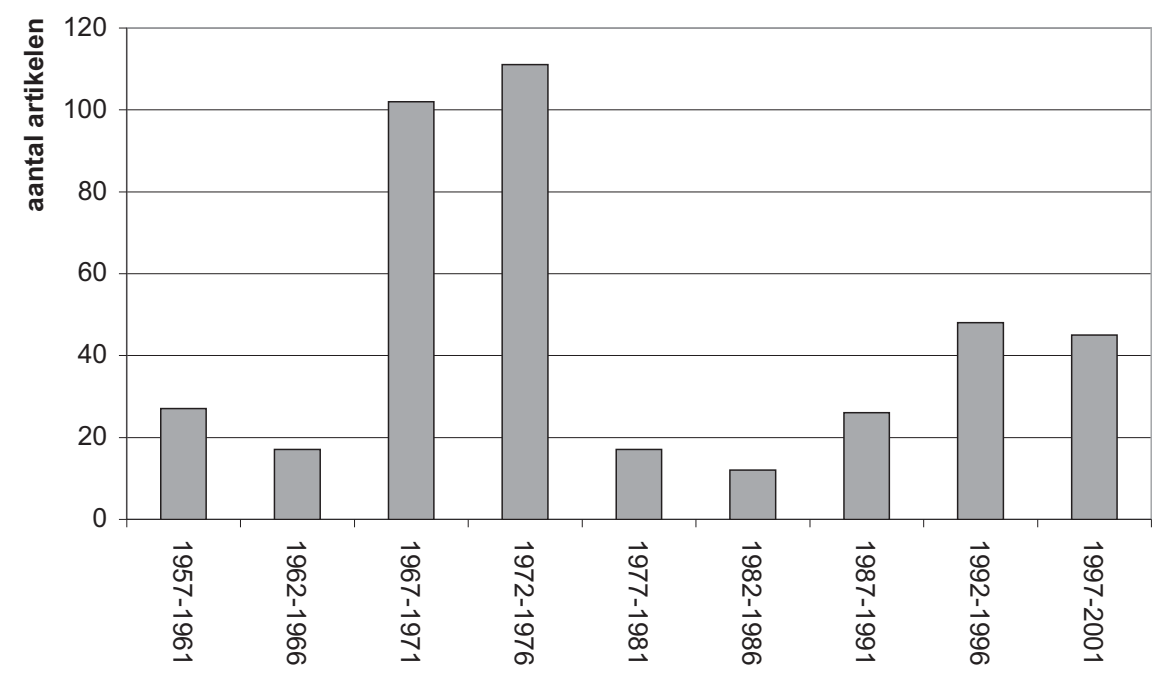

schetst. Het kwalitatieve deel vormt de kern van het hoofdstuk. Daar wordt nader ingegaan op de inhoud en achtergronden van de veranderende definiëring van 'de pendelproblematiek'.

\section{EEN EERSTE INDRUK}

In hoofdstuk 4 is geconstateerd dat de arbeidsmobiliteit vanuit Zuid-Limburg naar Duitsland in het begin van de jaren 1970 haar grootste omvang bereikte. In zijn hoogtijdagen stond de Duitslandpendel uitgebreid in de publieke belangstelling (zie figuur 5.1).

Meer dan de helft van de gevonden artikelen stamt uit de periode vanaf 1967 tot en met 1976. De grootte van de pendelstroom kan de spreiding van de artikelen echter niet helemaal verklaren. Ondanks de kleine omvang van de grenspendel in de jaren 1990, werd er ook in die periode relatief veel over geschreven. De aandacht voor de Duitslandpendel was tevens verbonden met de manier waarop hij door de jaren heen werd beoordeeld.

Gedurende de gehele periode had de berichtgeving over het werken in Duitsland veelal een normatieve lading. Er kunnen twee perioden worden onderscheiden in het oordeel dat uit de artikelen spreekt (zie figuur 5.2). Vanaf het einde van de jaren 1950 tot het einde van de jaren 1970 werd het werken in Duitsland overwegend afgekeurd. Uit een deel van de artikelen, met name in de eerste helft van de jaren 1970, sprak geen duidelijk oordeel over de grenspendel. ${ }^{2}$ In de tweede helft van de jaren 1970 trad een kentering op. Sindsdien werd er zo goed als altijd ingestemd met het werken in Duitsland. ${ }^{3}$

2 Het betreft hier dikwijls artikelen waarin de kwantitatieve ontwikkeling van de grenspendel werd beschreven, zonder dat er een normatief oordeel werd geveld.

3 In verband met de leesbaarheid is in deze figuur een indeling van de onderzoeksperiode in tijdvakken van vijf jaar gehanteerd, waardoor de indruk ontstaat dat de scheidslijn tussen 1976 en 1977 loopt. Deze loopt in de steekproef echter tussen 1977 en 1978: in de twee artikelen uit 1977 werd de Duitslandpendel als ongewenst gekarakteriseerd, terwijl hij in de drie artikelen uit 1978 werd geaccepteerd. Gezien het kleine aantal artikelen uit deze periode wordt echter globaal gesteld dat de kentering aan het einde van de jaren 1970 optrad. 
FIgUUR 5.2 VERDELING ARTIKELEN NAAR EVALUATIE VAN DE PENDEL NAAR

DUITSLAND, 1957-2001. ${ }^{4}$

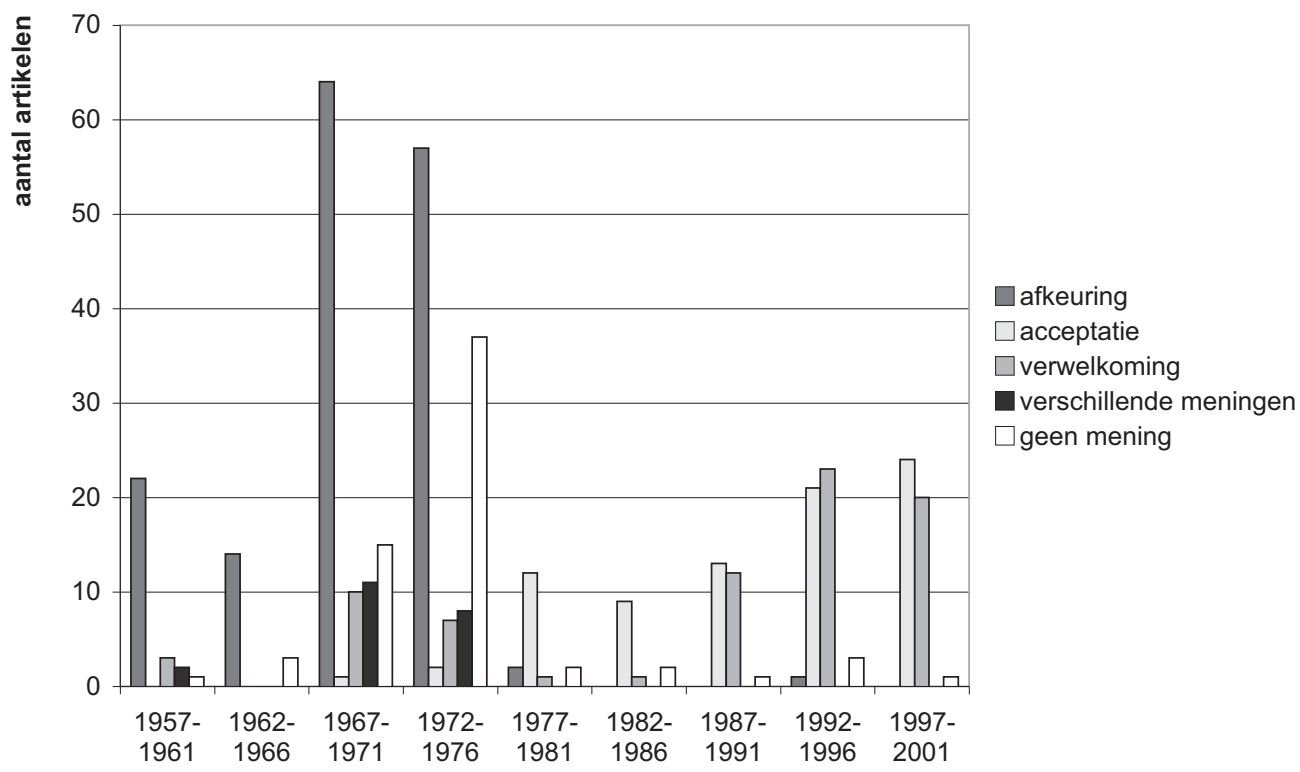

Zoals blijkt uit figuur 5.2 kreeg de verandering van de beeldvorming sinds het einde van de jaren 1970 geleidelijk haar beslag. In eerste instantie kon de grenspendel vrijwel uitsluitend op acceptatie rekenen, maar sinds het begin van de jaren 1990 werd hij ongeveer in gelijke mate verwelkomd. ${ }^{5}$ Er bestond dus steeds een verschil tussen de wenselijke en de werkelijke omvang van de pendelstroom, dat verbonden was met de aandacht voor de grenspendel in de Limburgse pers. Vanaf het einde van de jaren 1960 tot in de tweede helft van de jaren 1970 kwam de aandacht voort uit de spanning tussen de grote omvang en de afkeuring van de Duitslandpendel. In de jaren 1990 was het tegenovergestelde het geval: de Duitslandpendel werd verwelkomd, maar er werd slechts op zeer beperkte schaal in Duitsland gewerkt.

Samen met de evaluatie van de grenspendel wijzigde de aanwezigheid van verschillende partijen in de berichtgeving (zie tabel 5.1). In de eerste periode speelden Nederlandse regionale (Limburgse) autoriteiten en de Nederlandse sociale partners een prominente rol. Zij figureerden in ruim de helft van de gevonden artikelen en velden een negatief oordeel over de Duitslandpendel. Dat laatste gold eveneens voor vrijwel alle andere partijen. De grensarbeiders, Duitse autoriteiten en Duitse sociale partners vormden daarop een uitzondering, maar kwamen veel minder aan bod. ${ }^{6}$

4 Voor de categorisering van de oordelen: zie appendix B.

5 Het moment waarop de pendel werd verwelkomd komt door de in de grafiek gehanteerde tijdsvakken niet helemaal naar voren. In de steekproef vond de omslag plaats in 1991, toen de grenspendel in negen van de dertien artikelen werd toegejuicht, terwijl er in 1990 nog in acht artikelen sprake was van acceptatie en de pendel slechts in één artikel werd verwelkomd.

6 Ook Europese autoriteiten kwamen amper aan bod in de berichtgeving. Twee van de drie keer dat zij in de periode vanaf het einde van de jaren 1950 tot het einde van de jaren 1970 werden aangehaald, spraken zij wel over de 'pendelfricties' in Limburg als gevolg van de onevenwichtige ontwikkeling aan Nederlandse en Duitse zijde van de grens (de Nederlandse Europees Commissaris Mansholt in LD, 28-11-1970; de Europese Commissie in DNL, 29-1-1971). De derde keer stelde de Europese Commissie echter dat er vanwege het vrij verkeer van werknemers in beginsel geen onderscheid bestond tussen grenspendel en binnenlandse pendel (DL, 26-4-1974). 
In de tweede periode werd de berichtgeving gedomineerd door Nederlandse nationale en regionale politici, Nederlandse autoriteiten, (vertegenwoordigers van) de grensarbeiders en in de jaren 1990 tevens Euregionale autoriteiten. Evenals de andere partijen stemden zij steeds in met de grenspendel. Zoals gezegd ging dat gedurende de eerste tien jaar niet verder dan het aanvaarden van de grenspendel. Pas vanaf het begin van de jaren 1990 werd de grenspendel echt toegejuicht.

Opvallend is het sterk gekrompen aandeel van de journalisten in de berichtgeving. Tot in de tweede helft van de jaren 1970 betrof het overwegend redactionele commentaren. Blijkbaar was de grenspendel destijds een verschijnsel waarover redacties zich wilden uitspreken. De Duitslandpendel was in die tijd dan ook betrekkelijk omstreden. Dat komt ook tot uitdrukking in de relatief grote diversiteit aan opinies over grensarbeid (zie figuur 5.2). Vanaf het einde van de jaren 1960 tot in de tweede helft van de jaren 1970 was de publiciteit in de meeste gevallen uitgesproken negatief, maar viel er af en toe een positief geluid te beluisteren. In de periode erna werd er, zij het in verschillende gradaties, zo goed als altijd mee ingestemd.

\section{TABEL 5.1 PARTIJEN NAAR FREQUENTIE VAN HUN AANWEZIGHEID IN BERICHTGEVING PER PERIODE. ${ }^{7}$}

Partijen

1957-1977

1978-2001

Autoriteiten

Nederlandse nationale autoriteiten

$42 \quad 26$

Limburgse autoriteiten

Duitse autoriteiten (nationaal en regionaal)

$94 \quad 19$

Euregionale autoriteiten

Europese autoriteiten

$0 \quad 20$

3

2

Politici $^{8}$

Regionale en nationale politici (NL) ${ }^{9}$

Europese politici

\section{Werkgevers en werknemersorganisaties}

$\begin{array}{lll}\text { Nederlandse werkgevers(organisaties) en vakbonden }{ }^{10} & 63 & 19\end{array}$

Duitse werkgevers(organisaties) en vakbonden

\section{Overige partijen}

Grensarbeiders

$8 \quad 21$

Journalisten

Experts

$3^{6}$

18

Overig

7 Voor de categorisering van de partijen: zie appendix B. Doordat er in een groot deel van de artikelen naar meerdere partijen werd verwezen, is het aantal aangehaalde partijen in de berichtgeving groter dan het totale aantal artikelen.

8 Duitse politici kwamen niet voor in de berichtgeving.

9 De mening van de regionale en de nationale politici kwam grotendeels overeen. De aangehaalde nationale politici, oftewel leden van de Eerste en Tweede Kamer, waren ook veelal uit Limburg afkomstig.

10 De werkgevers(organisaties) en de vakbonden vertegenwoordigden veelal een zelfde visie op het pendelverschijnsel en zijn hier daarom in één categorie ondergebracht. 
Door de jaren heen ruimden sommige partijen dus goeddeels het veld om plaats te maken voor nieuwe. Zo beklommen de vertegenwoordigers van de grensarbeiders sinds het einde van de jaren 1970 het podium en volgden Euregionale autoriteiten pas met ingang van de jaren 1990. Hun instemming met de grenspendel komt niet als een verrassing. Later zal blijken dat zij echter een nieuw, instemmend, vertoog ten aanzien van de grenspendel vertegenwoordigden, dat evenzeer opgeld deed onder de reeds gevestigde en eerder kritische partijen. Waar kwam deze omslag vandaan?

De twee perioden in de beeldvorming corresponderen nagenoeg met de perioden die er in de kwantitatieve ontwikkeling van de pendelstroom kunnen worden onderscheiden. Zoals we zagen bestond er steeds een kloof tussen de gewenste en de werkelijke omvang van de Duitslandpendel. Toen het werken in Duitsland werd afgewezen, werd er op grote schaal in Duitsland gewerkt, terwijl er amper Zuid-Limburgers in Duitsland werkten in de tijd dat ermee werd ingestemd. Nu kan gesteld worden dat de grenspendel een grotere bedreiging vormt wanneer hij grotere vormen aanneemt en daarom tot in de tweede helft van de jaren 1970 werd afgekeurd. Uit de kwalitatieve analyse, die hierna per periode volgt, zal echter blijken dat het verhaal achter de cijfers onlosmakelijk was verbonden met de heersende conceptie van (Zuid-)Limburg als grensgebied.

\section{DEFINITIE VANUIT EEN BEGRENSD REFERENTIEKADER}

In de negatief getinte berichtgeving vanaf het einde van de jaren 1950 tot in de tweede helft van de jaren 1970 werd op drie domeinen gewezen waarin de pendel schade zou aanrichten: ten eerste de nationale economie, ten tweede, en in het bijzonder, de regionale arbeidsmarkt, en ten derde de persoonlijke situatie van de grensarbeiders. In deze paragraaf zal duidelijk worden dat deze definities van 'het pendelprobleem' voortkwamen uit een nationaal begrensde conceptie van Zuid-Limburg als grensgebied.

\section{Ten koste van 'de Nederlandse gemeenschap'11}

De periode na de Tweede Wereldoorlog stond in Nederland vóór alles in het teken van de nationale wederopbouw en het herstel van de welvaart. Opeenvolgende kabinetten namen daartoe diverse maatregelen, waarvan een geleide loonpolitiek een van de voornaamste was. Dat beleid kwam tot stand in het kader van afspraken met werkgevers- en werknemersorganisaties om de lonen te matigen. Loonsverhogingen werden opgegeven ten behoeve van het nationaal economisch herstel. Om het consumptiepeil wel aanvaardbaar te houden werden de prijzen en de huren gecontroleerd. Toen in het begin van de jaren 1960 verschillende bedrijfstakken met een zeer krappe arbeidsmarkt kampten, kwam dit loonbeleid onder druk te staan. Werkgevers, vooral in de Rotterdamse haven en de textielindustrie, gingen daardoor over tot de werving van personeel via koppelbazen en het betalen van hogere (zwarte) lonen. Dat leidde tot een loonexplosie, die in het najaar van 1963 uitmondde in een gezagscrisis voor de overheid, de werknemers- en werkgeversorganisaties en het corporatistische model. Koppelbazen die met hoge lonen Nederlandse arbeiders wierven voor de florerende Belgische en Duitse arbeidsmarkten, speelden hierbij eveneens een niet te verwaarlozen rol. ${ }^{12}$

11 Voorzitter van KAB-Limburg Maenen in DNL, 14-9-1960.

12 Windmuller et al., Arbeidsverhoudingen in Nederland, 155, 165-168, 190-193. 


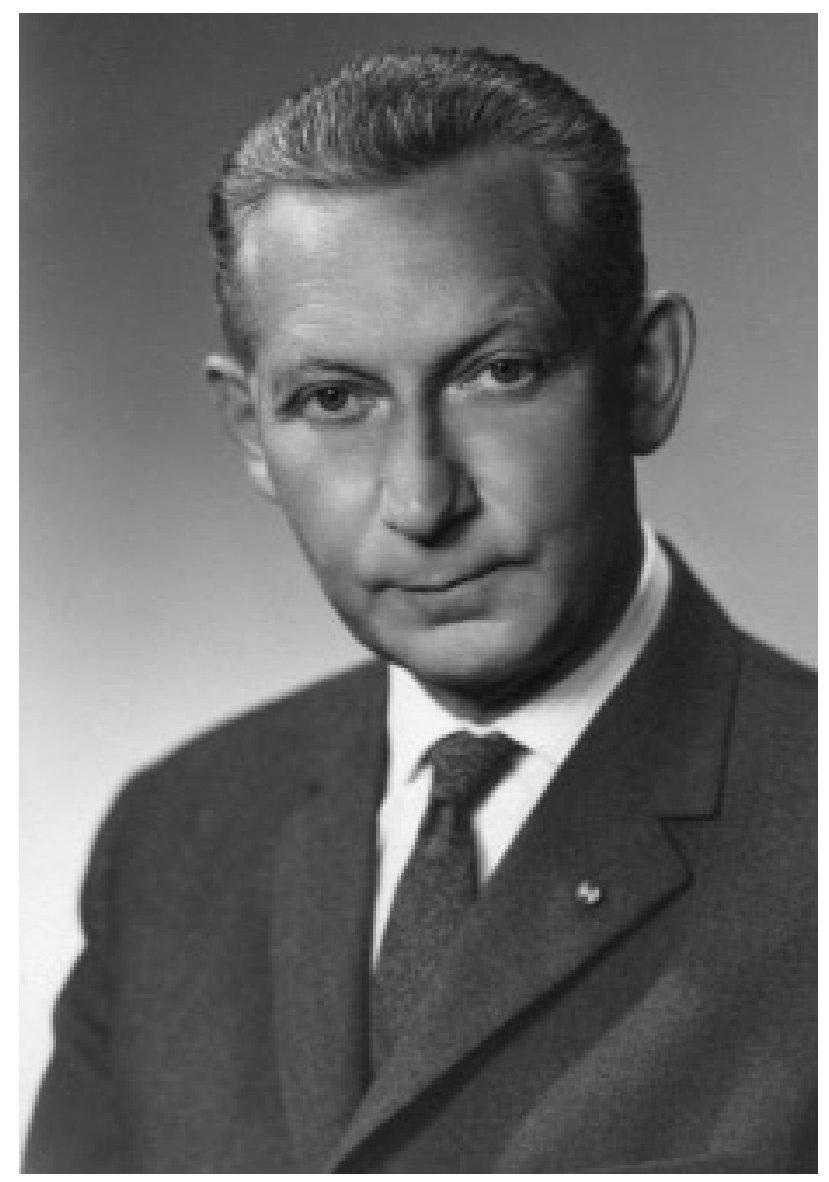

Jan Maenen.

Bron: Fotocollectie SHCL, K494.

In de Limburgse pers werd niet alleen de grenspendel via koppelbazen, maar het werken in Duitsland als zodanig strijdig bevonden met het naoorlogse economische beleid. De Duitse lonen waren zo hoog dat de uitstroom van schaarse arbeidskrachten een grote druk op de lagere Nederlandse lonen en prijzen zou leggen. Deze gedachtegang werd met name verwoord door Jan Maenen, die in de jaren 196o en de eerste helft van de jaren 1970 de berichtgeving over de grenspendel in verschillende hoedanigheden domineerde. ${ }^{13}$ Als voorzitter van de Limburgse afdeling van de Katholieke Arbeidersbeweging (KAB), die mede aan de wieg van het corporatistische model had gestaan en steun verleende aan de geleide loonpolitiek, zei hij in het begin van de jaren 1960 :

Wat de pendelende arbeiders betreft, die eigen gewin boven alles stellen, hun gaf hij [Jan Maenen] in overweging eens te bedenken, dat zij hun hoge gezinslonen hier consumeren en dus profiteren - om het maar 'ns heel vriendelijk uit te drukken - [...] van ons lagere levenspeil. Als zij nu in West-Duitsland gingen wonen, zouden de zaken anders staan. Terwijl hun arbeidskracht onttrokken wordt aan onze produktiviteit, wat geenszins in het belang is van onze nationale welvaart, die toch ook omhoog

13 Maenen was vanaf 1945 tot en met 1963 voorzitter van de afdeling Limburg van de Katholieke Arbeiders Beweging (KAB), tussen 1962 en 1971 Tweede Kamerlid voor de Katholieke Volkspartij (KVP) en vervolgens tot en met 1974 namens dezelfde partij lid van de Eerste Kamer. 
moet, versterken zij de consumptieve uitgaven, wat meewerkt in de richting van overbesteding waarbij niemands belang gediend is, ook niet de gezinnen der Duitslandgangers. Bovendien, en daar legde Jan Maenen de nadruk op: zij profiteren ook van de huurcompensatie en leven met hun gezinnen ook wat dit betreft op kosten van de Nederlandse gemeenschap. 'Kunnen wij nog wel van profiteren spreken, of moet er een harder woord gebezigd worden?', vroeg Jan Maenen zich af. ${ }^{14}$

Maenen schetste een sterk moraliserend beeld van de grensarbeiders als egoïstische freeriders die van twee walletjes aten. Zij zouden van de hoge lonen in Duitsland en de lagere prijzen in Nederland profiteren en zich daarmee niet loyaal opstellen jegens hun vaderland. Hij rekende hen zelfs aan dat zij de ontwikkeling van de Nederlandse economie op het spel zetten. Juist het feit dat de pendelaars in Duitsland werkten en in Nederland bleven wonen, zorgde volgens Maenen voor problemen. Door over de grens te gaan werken, onttrokken de grensarbeiders zich aan het gezag van de Nederlandse staat en importeerden zij ongewenste economische invloeden uit Duitsland. Als katholiek vakbondsleider zag Maenen het als een morele plicht van de Nederlandse bevolking om tegen een gematigd loon in eigen land te werken. De Duitslandgangers conformeerden zich niet aan deze norm en dreigden daarmee het nationaal economisch herstel te ondermijnen.

Het nationale economische beleid stuitte door de grenspendel zowel letterlijk als figuurlijk op zijn grenzen. Grensarbeid toonde de beperkingen van het principe van territorialiteit. Ondanks het bestaan van een duidelijk afgebakend staatsterritorium waarover de nationale overheid soevereiniteit genoot, was zij niet in staat de bevolking helemaal te controleren. Niettemin was het economisch beleid destijds gebaseerd op de veronderstelling dat de staat als economische container geen (grote) lekkages zou vertonen. De groeiende grenspendel liet zien dat dit een illusie was en confronteerde de Nederlandse staat in die zin met zijn beperkingen.

Onder druk van de loonexplosie liet de Nederlandse regering de teugels in 1963 enigszins vieren door de hoogste loonverhoging sinds het einde van de Tweede Wereldoorlog toe te staan. Terwijl de toegestane loonstijging in 1963 nog geen 3 procent bedroeg, werd deze voor het jaar erna op maar liefst 10 procent bepaald. Tijdens de economische recessie van 1966 en 1967 slaagde de overheid er nog korte tijd in de lonen laag te houden, maar in 1968 zag zij zich genoodzaakt de geleide loonpolitiek officieel te beëindigen. ${ }^{15}$

Het einde van de geleide loonpolitiek betekende niet dat grensarbeid niet langer als strijdig met het nationaal belang werd beschouwd. In 1974, toen de geleide loonpolitiek al ettelijke jaren was losgelaten en de pendelstroom reeds kromp, stelde hoogleraar bedrijfseconomie Tiemstra van de Katholieke Hogeschool Tilburg dat de grensarbeiders de Nederlandse overheid alleen maar geld kostten:

De Nederlandse gemeenschap heeft in iedereen f. 50.000 tot f. 70.000 'geïnvesteerd' aan opleiding, huisvesting en andere voorzieningen. Pendelaars voegen hun 'waarde' toe aan het inkomen van een ander land. Prof. Tiemstra schat die toegevoegde waarde op f. 1,2 miljard per jaar. ${ }^{16}$

14 DNL, 14-9-1960.

15 De implementatie van de Wet op de Loonvorming in dat jaar vormde het begin van een nieuw tijdperk in de Nederlandse loonvorming en arbeidsverhoudingen, waarin de overheid minder controle uitoefende (Windmuller et al., Arbeidsverhoudingen in Nederland, 221).

16 LD, 19-2-1974, op basis van een artikel over of van Tiemstra in Ruim Zicht, het blad van het Nederlandse Katholieke Vakverbond (NKV, die in 1964 de KAB opvolgde); zie ook DL, 22-8-1973 naar aanleiding van uitspraken van Tiemstra (in het artikel foutief 'Thienstra' genoemd) in de KRO actualiteitenrubriek ECHO; hij ging er in 1973 van uit dat er ongeveer 30.000 Limburgse grensarbeiders in Duitsland werkten, terwijl hij in 1974 uitging van een aantal van ongeveer 20.000, maar toch op dezelfde kostenpost uitkwam. 
Hij zag de grenspendel als export van menselijk kapitaal, waarin de Nederlandse overheid had geïnvesteerd en waar Duitsland de vruchten van plukte. De grensarbeiders betaalden immers belastingen en premies in Duitsland en droegen bij aan het verhogen van de productiviteit aldaar. Indien zij werkloos zouden terugkomen uit Duitsland zouden zij bovendien mogelijkerwijs aanspraak maken op Nederlandse uitkeringen. Dat noemde de hoogleraar 'onaanvaardbaar' ${ }^{17}$ Datzelfde jaar wierp de eerder aangehaalde Maenen, nu in de hoedanigheid van Eerste Kamerlid voor de Katholieke Volkspartij (KVP), in verband met de terugkeer van talloze werkloze Duitslandgangers de vraag op 'hoeveel miljoenen guldens er gemoeid zijn met de werkloosheidsuitkeringen van de pendelaars'. Hij noemde Nederland om die reden de 'melkkoe' van Europa. ${ }^{18}$ Dergelijke zorgen hielden verband met de uitdijende verzorgingsstaten, die steeds meer geld in sociale verzekeringen en voorzieningen voor burgers staken. Daardoor stond er op den duur meer op het spel als burgers over de grens gingen werken.

In de jaren 1960 en 1970 werd er vanuit nationaal perspectief dus overwegend negatief over de grensarbeiders geoordeeld. In een context van gescheiden sociaal-economische regimes werd het werken over de grens als een gevaar voor de Nederlandse economie getypeerd. Niet alleen doordat de pendelaars hun arbeidskracht aan de Nederlandse economie onttrokken, maar ook en juist doordat zij in Nederland bleven wonen, zouden zij voor moeilijkheden zorgen. Vanuit een begrensd betekeniskader waarbinnen (Zuid-)Limburg als integraal onderdeel van de Nederlandse staat werd benaderd en zijn belangen dus binnen deze context werden gedefinieerd, werd het werken over de grens als onwenselijk gekarakteriseerd.

\section{'Een noodgebied'19}

Behalve voor de nationale economie zou de Duitslandpendel met name slecht uitpakken voor de regionale arbeidsmarkt. Vanaf het einde van de jaren 1950 tot het einde van de jaren 1970 werd de term 'pendelprobleem' vooral in dit verband gebezigd. Vooral de grote omvang van de arbeidsstromen naar Duitsland en het gebrek aan pendel vanuit Duitsland naar (Zuid-) Limburg werd als problematisch bestempeld. In het eerder aangehaalde interview uit 1960 verwoordde de Limburgse katholieke vakbondsman Maenen het als volgt:

De sterke trek naar West-Duitsland heeft tot gevolg dat in een toenemend aantal bedrijven en ondernemingen de onderbezetting nog groter wordt en deze bedrijven, de hoogconjunctuur ten spijt, niet tot uitbreidingen kunnen overgaan en zij en anderen van nieuwe industrievestigingen moeten afzien. [...] Daarbij komt dan nog - en laten we daarbij de harde feiten niet verdoezelen, noch aan struisvogelpolitiek doen - dat de zuigkracht van de Westduitse lonen dus ook geen perspectieven biedt voor nieuwe industrievestigingen in de Oostelijke Mijnstreek, welke juist dáár zo broodnodig worden wegens de nieuwe situatie in de mijnindustrie. Alles met alles biedt het groeiende pendelen naar West-Duitsland allesbehalve gunstige perspectieven voor onze industrialisatiepolitiek. ${ }^{20}$

17 In DNL, 26-11-1970 wees het Limburgse Eerste Kamerlid van KVP, Franssen (tevens districtsvoorzitter van de Unie BLHP), er ook al op dat een deel van het verdiende geld weliswaar in Nederland werd besteed, maar dat dit niet opwoog tegen het productieverlies. 18 DL, 3-4-1974; zie ook LD, 4-4-1974. Zie ook LD, 2-11-1974. Ook het NEI stelde in 1976 nog dat grensarbeiders bij werkloosheid een Nederlandse uitkering ontvingen, terwijl zij uitsluitend in Duitsland premie hadden betaald en deze niet met Nederland was verrekend (Hendriks et al. De gevolgen van de pendel op Duitsland, 20). Dergelijke problemen zouden met de Europese Verordening 1408/71 eigenlijk uit de weg moeten zijn geruimd.

19 Maenen als lid van de Eerste Kamer voor de KVP in LD, 31-5-1972.

20 DNL, 13-9-1960. 
Maenen wees erop dat vooral de hoge Duitse lonen een grote pendelstroom naar Duitsland in de hand werkten. Daardoor zou het regionale arbeidsaanbod dermate krimpen dat de vestiging van nieuwe en de uitbreiding van bestaande bedrijven in gevaar zouden komen. Met het oog op de problemen die de Zuid-Limburgse mijnindustrie sinds de kolencrisis van 1958 ondervond, hechtte Maenen veel belang aan de ontwikkeling van nieuwe werkgelegenheid in de regio. Anderen deelden deze mening. Zo stelde een journalist van De Nieuwe Limburger drie jaar later dat de provincie mede door de Duitslandpendel een 'expulsiegebied' dreigde te worden. ${ }^{21}$

Met het aanzwellen van de pendelstroom ten tijde van de mijnsluitingen kreeg dit vertoog een extra impuls. Soms werd onderkend dat er al van oudsher Limburgers in Duitsland werkten. Door de krappe Duitse arbeidsmarkt en de problematische situatie in Zuid-Limburg zou de grenspendel in het begin van de jaren 1970 echter 'excessieve' en 'exorbitante' vormen hebben aangenomen..$^{22}$ De ontmanteling van de mijnbedrijven ging samen met een herstructureringsbeleid dat gericht was op het creëren van vervangende werkgelegenheid in Zuid-Limburg. Dat sloot aan bij het regionaal-economische beleid zoals dat sinds de jaren 1950 in Nederland werd gevoerd. Doel van dat beleid was in moeilijkheden verkerende, vaak perifere, regio's te ondersteunen om ontwikkelingsachterstanden ten opzichte van de rest van het land op te heffen. ${ }^{23}$ Volgens de geograaf Knippenberg bevorderde het herstructureringsbeleid de integratie van Limburg in de Nederlandse nationale staat. ${ }^{24}$ Onder opiniemakers heerste de gedachte dat de grenspendel het slagen van het herstructureringsbeleid in de weg zou staan. De trek van duizenden arbeidskrachten naar Duitsland zou het regionale arbeidsaanbod dusdanig beperken dat het aantrekken van nieuwe werkgevers ernstig werd bemoeilijkt. Zo was er volgens de Limburgse Kamers van Koophandel (KvK) door de 'abnormale en onrustbarende grenspendel' in 1970 'in plaats van [het] op grond van de mijnsluitingen verwachte arbeidsoverschot een nijpend tekort ontstaan'. ${ }^{25}$ Sommige reeds in Limburg gevestigde werkgevers zagen zich daarom genoodzaakt gastarbeiders in bijvoorbeeld Marokko en Turkije te werven om het productieproces op gang te houden. ${ }^{26}$ Dit werd als tijdelijke oplossing gezien om de werkgelegenheid in het gebied te handhaven.

Soms vielen er positievere geluiden te beluisteren. Zo nu en dan werd gesteld dat de pendel naar Duitsland een dempende werking had op de sociaal-economische problemen voorafgaand aan en tijdens de mijnsluitingen. Zo schreef een journalist in de eerste helft van de jaren 1960 dat het 'toch een uitkomst [was] dat geschoolde en ongeschoolde arbeiders, die hier niet of zeer moeilijk aan de slag kunnen, daar goed hun brood verdienen' ${ }^{27}$ Bijna tien jaar later zei de voorzitter van de Protestants-Christelijke Mijnwerkers Bond (PCMB), Feenstra, iets vergelijkbaars:

\footnotetext{
21 DNL, 14-11-1963.

22 DNL, 1-5-1970; Limburgse Eerste Kamerleden van de KVP Maenen, Horbach (tevens secretaris van de KvK Maastricht e.o. en secretaris van de RRA) en Franssen (tevens districtsvoorzitter van de Unie BLHP) in LD, 17-11-1972; LD, 8-12-1972; het blad van het Nederlands Christelijk Werkgeversverbond zoals aangehaald in DL, 14-7-1973; Eerste Kamerlid van de KVP en secretaris van de KvK Maastricht e.o. (tevens secretaris van de RRA), Horbach, in LD, 19-9-1973.

23 Van Oort en Raspe, Ruimtelijkeconomisch beleid in de kenniseconomie, 6-8.

24 Knippenberg, 'The incorporation of Limburg', 59.

25 Verwijzing naar brief aan de minister van Sociale Zaken in DNL, 29-10-1970.

26 Minister van Sociale Zaken Roolvink in LD, 25-7-1970; hoofdaalmoezenier Sampers van Sociale Werken te Maastricht in LD, 210-1970b; Tweede Kamerlid Portheine (VVD) in LD, 12-11-1970; DBA in DNL, 3-8-1971; minister Boersma van Sociale Zaken in LD 315-1972 (over de DAF-fabriek in Born).

27 DNL, 23-2-1961.
} 


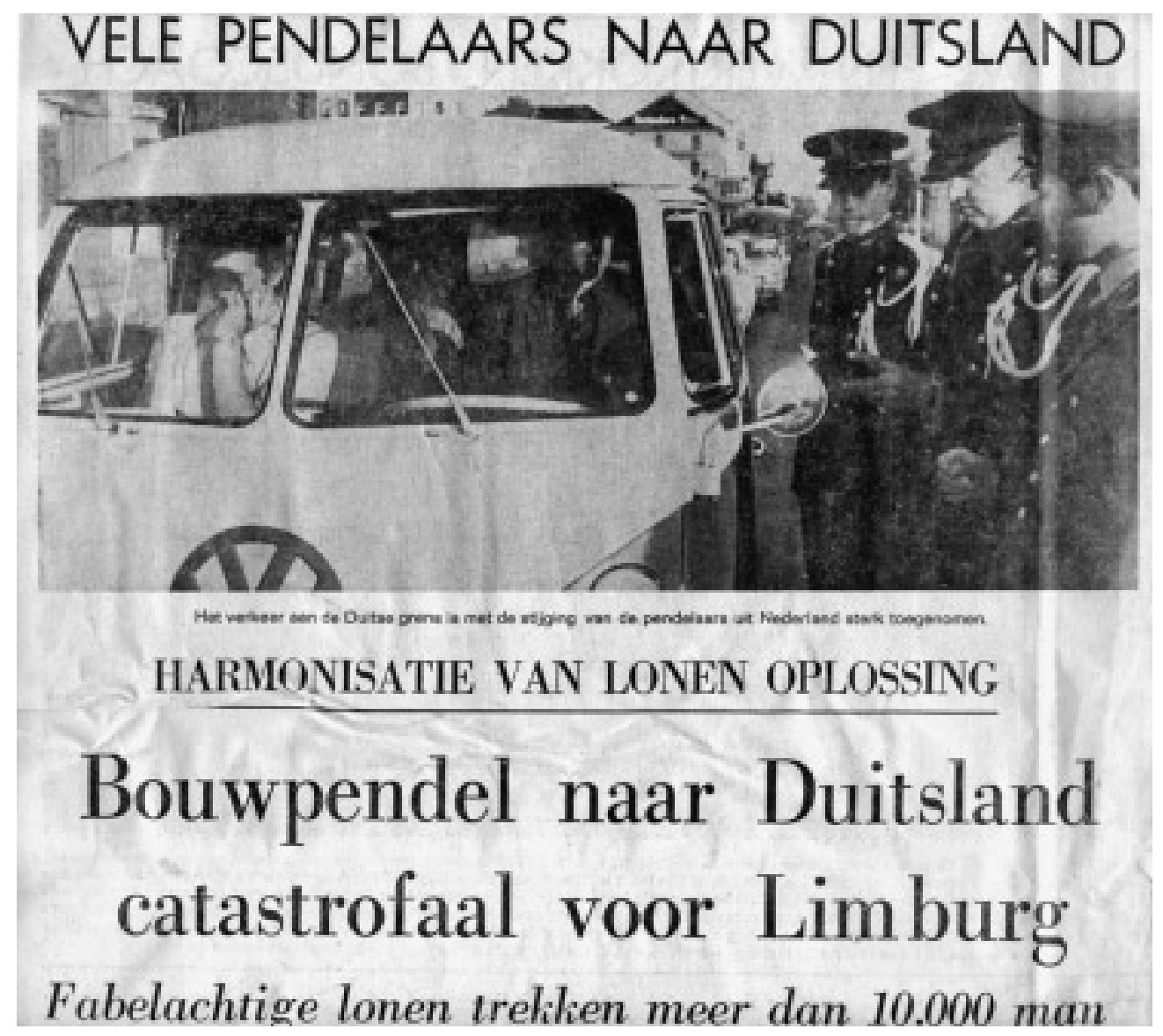

In krantenkoppen werd de onrust over de grenspendel treffend verwoord. Bron: De Tijd, 16-7-1970 (SHCL: EAN 65: 1933).

Het is voor Limburg een geluk dat de pendel er in deze overgangstijd is. Want hoe zou het zijn als deze 12.000 pendelaars voor de poort van het arbeidsbureau zouden staan op dit moment. [...] De 12.00o personen die dagelijks van Nederland naar Duitsland reizen, doen dat niet uit luxe maar uit de noodzaak om een belegde boterham te verdienen [...] De meeste pendelaars zijn gewoon ongeschikt voor het werk in de nieuwe bedrijven [in Zuid-Limburg]. Bovendien, ze willen daar voor het merendeel jonge mensen. En die zijn er niet. In zo'n situatie [...] is het maar heel goed dat men gaat pendelen. Die mensen bewijzen dat ze willen werken en niet in de WW [Werkloosheidswet] willen lopen. ${ }^{28}$

De pendel zou ervoor zorgen dat de (Zuid-)Limburgse arbeidsmarkt 'voor verder afglijden [werd] behoed' ${ }^{29}$ Ook grensarbeiders gaven aan dat het werken in Duitsland een manier was om werkloosheid te voorkomen. ${ }^{30}$ Toch gold het uitsluitend als 'noodoplossing' voor de regionale problemen. ${ }^{31}$ Werk vlak over de grens in Duitsland werd niet als volwaardige vervanger voor werk binnen de landsgrens gezien.

\footnotetext{
28 Geciteerd uit het PCMB-blad De Mijnarbeider in DNL, 21-12-1970. In 1970 werkten er volgens de cijfers van het Districtsbureau voor de Arbeidsvoorziening (DBA) zo'n 14.00o Limburgers in Duitsland (Arbeidsmarktbeschrijuing 1970, tabel 13).

29 DBA Limburg in LD, 5-9-1973.

30 Twee ingezonden brieven in LD, 18-3-1971.

31 Journalist in LD, 26-8-1970.
} 
Voor 'de middengroepen', zoals administratief personeel, was het erg moeilijk om werk te vinden aan de andere kant van de grens..$^{32}$ De grote trek naar Duitsland van vooral handarbeiders zou het creëren van nieuwe arbeidsplaatsen voor voormalige mijnbeambten bovendien bemoeilijken, waardoor zij 'gedwongen [waren] buiten Limburg werk te vinden'. Het Limburgse Tweede Kamerlid Bremen van de KVP beweerde daarom dat Limburg 'het Marokko voor Duitsland [dreigde] te worden' en het gevaar liep 'leeg te lopen'. ${ }^{33}$ Volgens de districtsvoorzitter van de Unie voor Beambten Leidinggevend en Hoger Personeel (Unie BLHP), Franssen, fungeerde de Limburger 'als gastarbeider in Duitsland' ${ }^{34}$ Duitse autoriteiten gaven ook aan dat de Limburgse grensarbeiders als goedkoper alternatief voor de gastarbeiders uit onder meer Turkije golden. ${ }^{35}$ Lange tijd heerste de gedachte dat gastarbeid een additioneel, en dus tijdelijk, karakter had. Bij economische achteruitgang zouden gastarbeiders hun baan als eerste verliezen en terugkeren naar hun land van herkomst. ${ }^{6}$ De vergelijking met gastarbeid impliceert dat grensarbeid gepaard ging met afhankelijkheid van het werkland. En juist hierin zat de crux van het pendelprobleem vanuit regionaal-economisch oogpunt.

De kern van het probleem, zoals dat door met name Limburgse autoriteiten, politici en journalisten en Nederlandse sociale partners werd geformuleerd, was dat de omvangrijke pendelstroom (Zuid-)Limburg overleverde aan de economische grillen van het buurland. Een recessie in Duitsland zou het 'gevaar van een plotselinge verstoring der arbeidsmarkt' met zich meebrengen. ${ }^{37}$ Grensarbeiders liepen dan immers het risico massaal ontslagen te worden, om vervolgens terug te keren naar (Zuid-)Limburg waar zij ook geen baan zouden kunnen vinden. Duitslandpendel werd daarom getypeerd als een vorm van 'uitgestelde werkloosheid' die als een 'zwaard van Damocles' boven (Zuid-)Limburg hing. ${ }^{8}$ In tijden van economische teruggang, zoals in 1966 en 1967 en tijdens de crisis die eind 1973 inzette, werd de gevreesde terugkeer van ontslagen pendelaars werkelijkheid. In de pers werd deze in verband gebracht met de groeiende regionale werkloosheid en de afhankelijkheid van de Duitse arbeidsmarkt die het toonde. ${ }^{39}$ Opvallend is dat daarbij niet expliciet werd verwezen naar het grote aantal Duitslandgangers dat in de conjunctuurgevoelige bouw werkte. ${ }^{40}$ Kennelijk zat het probleem niet zozeer in de sterke conjunctuurgevoeligheid als wel in de afhankelijkheid van het buurland die de pendel in zich droeg.

32 Bestuur Industrieschap Oostelijke Mijnstreek (een in 1960 opgericht samenwerkingsverband tussen gemeenten uit de Oostelijke Mijnstreek ter bevordering van de industriële ontwikkeling in het gebied (Messing, Geschiedenis van de mijnsluiting, 263)) in DL, 30-31973; zie ook de districtsvoorzitter van de Unie BLHP, (tevens Eerste Kamerlid van de KVP), Franssen, in LD, 17-11-1972.

33 LD, 1-3-1973; zie ook voorzitter NKV district Limburg, Wijers, in DL, 30-5-1973; PvdA-Kamerlid Knot, in DL, 9-6-1973; DBA Limburg in DL, 5-9-1973.

34 Districtsvoorzitter van de Unie BLHP, Franssen (tevens Eerste Kamerlid namens de KVP), in LD, 2-6-1972.

35 Volgens de voorzitter van het Stichting Economische Ontwikkeling Limburg (SEOL) (de SEOL werd in 1972 op initiatief van de provincie Limburg opgericht om de acquisitie van bedrijven in de diensten- en industriële sector te bevorderen (Messing, Geschiedenis van de mijnsluiting, 466-467) en lid van de Regionale Raad voor de Arbeidsmarkt (RRA) Limburg, Hubben, in LD, 20-4-1973; journalist n.a.v. de resultaten van een bezoek van de RRA Limburg aan het Landesarbeitsamt Nordrhein-Westfalen in LD, 30-5-1973; zie ook LD, 17-11-1972.

36 Zie bijv. Van Amersfoort, 'From workers to immigrants'.

37 DBA Limburg in DNL, 25-7-1970 (zie ook bijv. DBA, Arbeidsmarktbeschrijuing 1965, 50).

38 VVD-lijsttrekker, Geertsema, ten tijde van de Tweede Kamerverkiezingen in LD, 22-4-1971b; de vice-voorzitter van de werkgeversfederatie in de bouw (AVOB), Van Kan, in LD, 9-10-1973; zie ook een journalist in DNL, 29-4-1964; Limburgse werkgevers in LD, 25-11-1969; LD, 26-8-1970; voorzitter van de Nederlandse Katholieke Mijnwerkers Bond (NKMB), Dohmen, in DNL, 28-9-1970.

39 LD, 27-10-1966; DL, 12-12-1973; DL, 11-1-1974a en b; cijfers DBA in DL, 9-10-1974.

40 Er werd wel op gewezen dat de Limburgse bouwbedrijven zwaar te lijden hadden onder de pendel doordat er zo veel bouwvakkers in Duitsland werkten (zie bijv. secretaris van de Limburgse aannemers- en patroonsbond, Lückers, en districtsbestuurder van de Katholieke Bouwvakkersbond St.-Joseph, Goossens, in LD, 8-7-1970; secretaris van de KvK Maastricht e.o., Horbach (tevens Eerste Kamerlid namens de KVP en secretaris van de RRA), in DNL, 3-10-1970). 
De afkeer van de afhankelijkheid van het buurland die met de grenspendel gepaard ging, hing samen met het streven naar een zelfvoorzienende arbeidsmarkt binnen de landsgrens. Volgens de Regionale Raad voor de Arbeidsmarkt (RRA) mocht Nederland, en met name Limburg, geen 'toeleveringsgebied voor de Duitse industrie worden'. Integendeel, het moest zelf 'een agressieve wervingspolitiek gaan voeren' en 'het hoofd niet in de schoot leggen'. ${ }^{41} \mathrm{De}$ RRA stelde verder dat 'de werkgelegenheidssituatie [...] pas dan bevredigend kan worden genoemd indien de bevolking in de gelegenheid is in eigen streek passend werk te vinden' ${ }^{42}$ Het Nederlands Christelijke Werkgeversverbond verwoordde het scherp:

[...] zij die stellen dat Limburg met pendel beter af is dan zonder, hebben gelijk. Ook een kreupele is met krukken beter af dan zonder. Maar men kan toch beter valide zijn [...]. ${ }^{43}$

Zelden werd de mening verkondigd dat de Limburgse arbeidsmarkt zich uitstrekte over de landsgrenzen en dat dit moest worden geaccepteerd. ${ }^{44}$ Hoewel de meeste grensarbeiders op niet al te grote afstand van hun woonplaats werkten, stond werken over de grens niet gelijk aan werk in de regio binnen de landsgrenzen. Dat is kenmerkend voor het nationaal begrensde referentiekader waarbinnen de Duitslandpendel in deze periode werd geduid, en waarbinnen (Zuid-)Limburg als perifeer, maar wel integraal deel van de Nederlandse staat gold.

De algemene strekking van de berichtgeving was dus dat grenspendel de regionale werkgelegenheidsontwikkeling binnen de nationale grenzen verstoorde door het arbeidsaanbod drastisch te beperken. Een journalist sprak van een 'negatief ontladingseffect' dat het resultaat was van economische zwakte en bijdroeg aan de handhaving ervan.45 Aansluitend daarbij werd in het begin van de jaren 1970 dikwijls betoogd dat de omvangrijke pendelstroom naar Duitsland de problemen van (Zuid-)Limburg versluierde. Hij hield de werkloosheidscijfers laag, waardoor de indruk kon ontstaan dat het goed ging met de regionale arbeidsmarkt. Maar schijn zou bedriegen: de regionale werkgelegenheid binnen de landsgrenzen was immers niet afdoende om de in (Zuid-)Limburg woonachtige beroepsbevolking aan een baan te helpen. ${ }^{46}$

\section{'Een dagelijks probleem voor de pendelaars zelf ${ }^{47}$}

De Duitslandpendel zou ook de grensarbeiders zelf in moeilijkheden kunnen brengen. Door over de grens te werken zouden zij hun persoonlijke ontwikkeling, gezinsleven en financiële en arbeidspositie op het spel zetten. Dit heeft op het eerste oog weinig te maken met de positie van (Zuid-)Limburg als grensgebied en de grens. Toch zal blijken dat het daar wel mee was of werd verbonden.

41 Secretaris van de RRA Limburg, Horbach (tevens secretaris KvK Maastricht e.o. en Eerste Kamerlid namens de KVP), in LD, 295-1973b. De RRA was een in 1971 opgericht regionaal sociaal-economisch overleg- en adviesorgaan waarin sociale partners en het provinciebestuur zetelden (Messing, Geschiedenis van de mijnsluiting, 468).

42 RRA in een aangehaalde brief aan de Ministerraad in LD, 6-10-1973; zie ook DL, 5-10-1973; vgl. de directeur van het arbeidsbureau in Heerlen in DNL, 14-8-1968.

43 Citaat uit het blad van het Nederlands Christelijke Werkgeversverbond ('De Werkgever') in DL, 14-7-1973. 
Vooral in redactionele commentaren was er veel aandacht voor de consequenties van de grenspendel voor de pendelaars zelf. Journalisten toonden zich allereerst bezorgd over de vele jongeren die in Duitsland werkten. In december 1960 wijdde het Limburgs Dagblad een serie van drie artikelen aan het groeiend aantal Limburgse tienermeisjes dat actief was in de Duitse kleding- en textielindustrie. ${ }^{48}$ In het eerste artikel werd erop gewezen dat dit volgens de Nederlandse wetgeving gelijk stond aan kinderarbeid:

Veertienjarigen mogen in Nederland niet op fabrieken werken, tenzij er voldaan wordt aan enkele belangrijke voorwaarden. De Bondsrepubliek evenwel haalt hen zonder bezwaar binnen. Met hoge lonen des vrijdags of des zaterdags huiswaarts kerende van over de grens, profiteren Nederlandse meisjes van de hen nu gegeven mogelijkheid, geld, veel geld uit te geven. Nadelen zijn tot in den treuren opgesomd door de zich verantwoordelijk voelende ouderen (nu de vader en de moeder van de onvolwassene verstek laten gaan): het meisje ontvangt geen enkele vorming [...] 'omdat het daar de tijd en de gelegenheid niet voor heeft'. Tweede grote nadeel: geestelijk zijn deze kinderen niet opgewassen tegen 't milieu waar zij volkomen 'blank' in treden, de fabrieksmentaliteit groeit hen in de kortste keren boven het hoofd. [...] Op alles bedacht zijnde opvoeders halen als andere grote bezwaren naar voren: onvoldoende slaap, het geestelijk neerhalende van lange, eentonige busreizen onder een groep meisjes van dezelfde leeftijd, het ver van huis vertoeven. 'De sfeer in de Duitse fabrieken is op zijn zachtst uitgedrukt vaak niet erg stichtend', vertellen de zich verantwoordelijk-voelenden. ${ }^{49}$

Men was bang dat het verkeerd zou aflopen met deze meisjes als zij echte 'fabrieksmeisjes' werden, 'die in de wintertijd nauwelijks door de week nog (Nederlands [sic]) daglicht' zagen. Hun ouders werden ervan beschuldigd 'de kinderarbeid-ellende weer in eigen huis' te halen..$^{\circ}$ Door hun kinderen in Duitsland te laten werken, onttrokken zij zich aan de Nederlandse wet die stelde dat kinderen tot een bepaalde leeftijd niet mochten werken en leerplichtig waren, wat nadelig zou uitpakken voor deze kinderen. Deze zorg gold eveneens voor jongens die in Duitsland werkten..$^{1}$

Daarnaast bestond er veel ongenoegen over de pendel van volwassenen, omdat deze ingrijpende consequenties zou hebben voor het gezinsleven. Dat komt duidelijk naar voren in een artikel uit 1961 met de kop 'Ter wille van het geld gaan huisvrouwen over de grens werken. Ook Limburgse kinderen de dupe?'. In dit artikel sprak een journalist de vrees uit dat de toename van het aantal huismoeders dat in Duitsland werkte, zou leiden tot de import van het verondersteld Duitse verschijnsel Schlüsselkinder, oftewel 'sleutelkinderen' wier beide ouders werken en die overdag aan hun lot worden overgelaten. ${ }^{52}$ Deze ideeën zijn nauw verbonden met de destijds vigerende traditionele katholieke moraal, die moeders voorschreef thuis te blijven om voor de kinderen te zorgen. ${ }^{53}$ De pendel van vrouwen in Duitsland druiste daar tegenin en werd daarom gediskwalificeerd. Maar mannen werd het evengoed kwalijk genomen dat zij in Duitsland werkten. Dit was en werd echter niet zozeer met de grens verbonden, als was van de welwillendheid van de Duitse werkgever. De Duitse werkgevers waren in tegenstelling tot de Nederlandse niet verplicht de jongere werknemers onder werktijd beroeps- of vormingsonderwijs te laten volgen (DNL, 7-3-1969).

51 DNL, 7-3-1969.

52 DNL, 19-4-1961a.

53 Wijers, 'In de schaduw van het kruis', 51-57. 


\section{MENSEN en DINGEN}

Gracionde ongerwetbid onder de industrikten

Spreken de ronselaars de waarheid?

\section{Er dreigt een ontıolking san}

\section{Limburg door de uittocbt} naar Duitsland

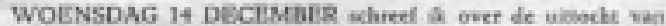
MANNEN in VROUWEN fot kindenes vas 14 far toef naar DUITSE FABRIEKFN. IBeacties van INDUSTRleLEN. van

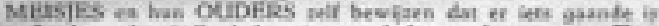
in Limburg dat stelle dades rat van de bevoegde insariten. Terwill Lageliks hes wastal vas ia let Durse grendebied werk vir: dende Limbargers proest bilwen de overheden machiteloos soezien. indestritien. die lin beste krachen wej rien treiken, kamen

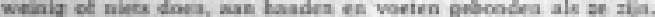
Ea irtumen gast kideren tes groade en worden gezisnts ontwortelly

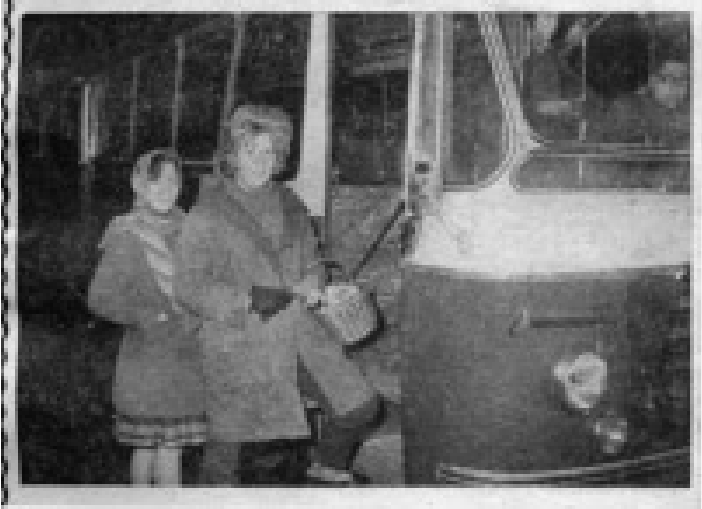

Nog een voorbeeld van de onrust die de grenspendel in de pers teweegbracht. Bron: LD, 21-12-1960 (SHCL: DOC 0041: 22585).

wel met de grote afstand die vooral weekpendelaars overbrugden. Door hun veelvuldige afwezigheid thuis zouden zij hun gezinsleven in gevaar brengen. Een journalist van De Limburger sprak over de 'ontwrichting van het gezinsleven' als 'de belangrijkste schaduwzijde van het pendelwerk'. ${ }^{54}$ Een Limburgse werkgever deed er nog een schepje bovenop en sprak van de 'ontworteling' van gezinnen en 'desintegratie van de christelijke samenleving' als zowel vader, moeder als kinderen in Duitsland zouden werken. ${ }^{55}$

54 DL, 1-3-1973. Zie ook Maenen als voorzitter van de KAB, in DNL, 14-9-196o; de voorzitster van de vrouwenbeweging in Limburg en de Nederlandse NKV, Stollman, in DNL, 18-11-1970a; lid van Provinciale Staten namens de Boerenpartij, Hartog, in DNL, 11-121970.

55 Een Hoensbroekse industrieel in LD, 21-12-1960 (zie ook afbeelding). 
Duitslandgangers die via koppelbazen of onderaannemers werkten, zouden eveneens veel op het spel zetten. De pers rapporteerde geregeld over koppelbazen of onderaannemers die de grensarbeiders zouden uitbuiten en illegaal tewerk zouden stellen. Dergelijke 'ronselaarsparasieten' zouden halve waarheden vertellen door bijvoorbeeld onvermeld te laten hoe hoog het werktempo in Duitsland lag. ${ }^{56} \mathrm{Er}$ deden geruchten de ronde waarin grensarbeid via deze intermediairs werd vergeleken met 'slavenhandel'. ${ }^{57}$ Duitse werkgevers en autoriteiten zouden nauwelijks oog hebben voor de soms abominabele omstandigheden waaronder de pendelaars werkten. Hun enige zorg zou zijn 'de beschikking [te] krijgen over de nodige hardwerkende arbeidskrachten'.$^{5^{8}}$ Een vertegenwoordiger van het Landesarbeitsamt Rheinland-Westfalen beweerde niettemin dat 'de gesignaleerde slavenhandel zich beperkte tot "Einzelfälle". 59 Behalve dat zij de grensarbeiders zouden exploiteren, zouden de koppelbazen zonder medeweten van de grensarbeiders frauderen met de kinderbijslag en de verzekeringen van de grensarbeiders. ${ }^{60}$ Clandestiene activiteiten van koppelbazen waren mogelijk vanwege de onduidelijke positie van de grensarbeiders tussen de twee systemen van wet- en regelgeving, en hun onwetendheid daarover en over de voorschriften rond arbeidsomstandigheden in Duitsland. In reactie op deze praktijken verscheen er in een serie commentaren onder de titel Visie op Limburg een stuk waarin een journalist de grensarbeiders opriep de koppelbazen 'de nek om [te] draaien'. ${ }^{61}$ In een ander artikel kwamen grensarbeiders aan het woord die door malafide koppelbazen waren bedrogen en aangaven nooit meer via een tussenpersoon of helemaal nooit meer in Duitsland te gaan werken. ${ }^{62}$ Op andere momenten werd er echter op gewezen dat grensarbeiders zelf fraude pleegden door met een Nederlandse uitkering 'zwart' in Duitsland te gaan werken. Het betrof dan bijvoorbeeld oud-mijnwerkers die een uitkering ontvingen in het kader van de Wet op de Arbeidsongeschiktheidsverzekering (WAO) of in het kader van de Werkloosheidswet (WW), of die gebruik maakten van een overbruggingsregeling tot hun pensioen. De directeur van het Gemeenschappelijk Administratie Kantoor (GAK) in Maastricht, dat onder meer verantwoordelijk was voor de registratie van de werkloosheidsverzekering en de kinderbijslag, waarschuwde voor de mogelijke consequenties van dit gedrag:

De WAO- en WW-trekkers steken het geld in hun zak, maar gaan daarnaast werken in Duitsland. Wanneer wij zo iemand betrappen wordt de uitkering meteen stopgezet. Mocht een illegale pendelaar ziek worden dan krijgt hij geen rooie cent en mocht hij in het meest tragische geval bij een ongeluk het leven verliezen, dan hebben de nabestaanden geen enkel recht meer op een uitkering krachtens de sociale verzekeringswet. De zwarte pendelaars beduvelen daarom niet alleen de gemeenschap, ze brengen ook hun gezin in de grootste moeilijkheden. ${ }^{63}$

Hij wees op de verantwoordelijkheid van de grensarbeiders ten opzichte van de Nederlandse gemeenschap en hun gezin. De auteur van het artikel zwakte zijn commentaar enigszins af

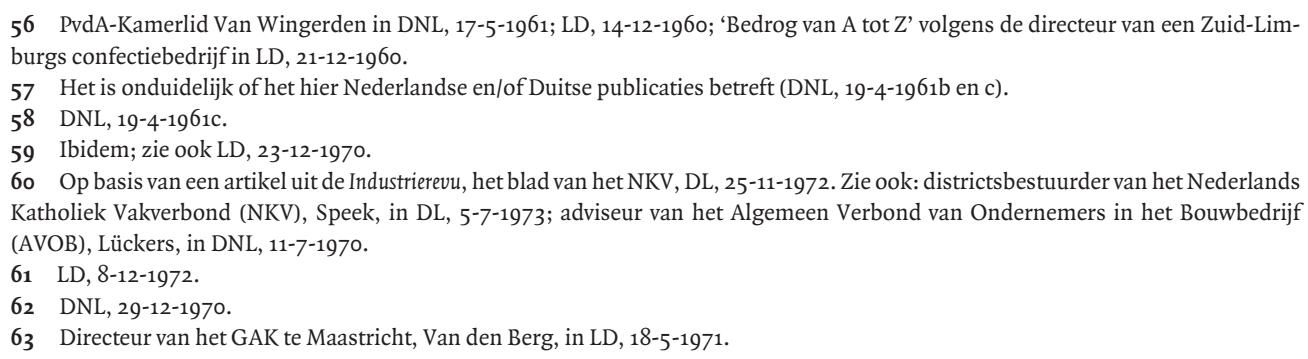


door eraan toe te voegen dat sommigen van hen 'uit nood tot werken in Duitsland [waren] gedwongen' en dat het hen dus niet altijd persoonlijk kon worden aangerekend, maar zij namen volgens hem wel bijzonder grote risico's. ${ }^{64}$

Naast de journalisten, toonden uit Limburg afkomstige politici, Limburgse autoriteiten en vakbonden zich ongerust over de gevaren die de grensarbeiders liepen. Deze lijken niet direct verbonden met de positie van (Zuid-)Limburg als grensgebied en de grens, maar waren en werden daar dikwijls toch aan gerelateerd. De afwijkende economische situatie en wetgeving aan Duitse zijde van de grens boden de (Zuid-)Limburgers mogelijkheden die in Nederland niet bestonden. Vanwege de beperkte aansluiting tussen beide wettelijke systemen was het tevens makkelijker de mazen in de wet op te zoeken. Bovendien werd de vrees uitgesproken dat de grensarbeiders slechte gewoonten van de Duitsers zouden overnemen. Door deze risico's te nemen zouden de grensarbeiders behalve zichzelf ook hun gezin en de nationale en regionale gemeenschap schade berokkenen. ${ }^{65}$ In 1970 vatte een journalist van het Limburgs Dagblad het als volgt samen:

Maar behalve dat pendelen voor de overheid een structureel probleem is van de Limburgse arbeidsmarkt, is pendelen ook een dagelijks probleem voor de pendelaars zelf. Hij moet uit de handen zien te blijven van koppelbazen en ronselaars en goed uit zijn doppen kijken om van sociaal verzekeringspunt uit, geen risico te lopen. Nog belangrijker is dat hij voortdurend blijft beseffen waarvoor hij gekozen heeft en waarom. Aan pendelen zit nu eenmaal vast: ver(der) reizen van en naar het werk. En als dan het beter gevulde loonzakje voor een niet onbelangrijk gedeelte moet komen van overuren maken, worden voor de pendelaars de werkdagen wel erg lang en de vrije avonden en nachten wel erg kort. Het gevaar zit erin - het bouwvakblad wijst daar terecht op - dat de keuze van de pendelaar ten gunste van het dikkere loonzakje, uitvalt ten nadele van zijn gezondheid, zijn gezinsleven, zijn vrije tijd, kortom ten nadele van een heleboel dingen die het leven méér waard maken om geleefd te worden, dan werken en geld verdienen. Het is de moeite waard zich af te blijven vragen of dit de juiste keuze is.Werken, slapen, beuren, allemaal mooi, maar wat heb ik dan nog aan mijn leven? Is dat het waard? Als men geen tijd of geen fut meer overhoudt om het meerverdiende zinvol uit te geven, waarom dan meer verdiend? Hebben wij dan het geld of heeft het geld ons? Zo is pendel ook een menselijk, een "huiselijk" probleem, een levensprobleem, waarbij fundamentele waarden in het geding zijn. ${ }^{66}$

\section{'Een nationale zaak' ${ }^{6_{7}}$}

Hoewel 'het pendelprobleem' in deze periode dus een meervoudige invulling kreeg, ging het in de berichtgeving voornamelijk over de regional-economische problemen die de grenspendel zou veroorzaken. De grensforensen werden aangesproken op de schade die zij de nationale economie, zichzelf en hun gezin berokkenden, maar de verantwoordelijkheid voor de

64 Een journalist in LD, 18-5-1971.

65 DNL, 4-3-1961; bestuurslid van de Katholieke Bond voor Metaalbewerkers St. Eloy, Hajenuis, die de grensarbeiders waarschuwde niet alleen naar het geld te kijken, maar ook naar hun positie en rechten, in LD, 20-1-1971 (in dit artikel werd een bijeenkomst aangekondigd die St. Eloy organiseerde in samenwerking met haar Belgische evenknie, om naar Duitsland pendelende metaalbewerk(st)ers daarover te informeren (zie ook het verslag daarvan, waarin aan het einde werd opgemerkt dat veel grensarbeiders gebruik maakten van de gelegenheid om lid te worden van deze bond(en) (DNL, 25-1-1971)); zie ook DNL, 8-12-1970.

66 LD, 26-8-1970 (cursivering overgenomen van origineel). Zie eerder ook DNL, 4-3-1961.

67 Dhr. Hubben tijdens een vergadering van de Kamer van Koophandel en Fabrieken van de Mijnstreek (tevens bestuurslid van SEOL en lid van de RRA), in DL 22-6-1973. 
regionale arbeidsmarktsituatie werd zelden bij hen gelegd. Meestal, en vooral sinds de tweede helft van de jaren 1960, werd de Nederlandse nationale overheid daarop aangesproken. ${ }^{68}$ Een vertegenwoordiger van de Kamer van Koophandel en Fabrieken (KvK) van de Mijnstreek wees de regering in 1973 op haar plichten ten aanzien van Limburg:

Toen hier de mijnen nog draaiden was er geen pendelprobleem, dat is juist ontstaan door het sluiten van de mijnen. En omdat die mijnsluitingen geen Limburgse maar een nationale zaak zijn, is de pendel ook een nationale. ${ }^{69}$

Toen de regering in 1965 haar plannen bekendmaakte om de Zuid-Limburgse mijnbouw af te bouwen, beloofde zij geen mijnen te sluiten zonder dat er voldoende vervangende werkgelegenheid was gecreëerd. ${ }^{70}$ Vanaf dat moment werd het als haar verantwoordelijkheid gezien om voldoende nieuwe banen te scheppen. Omdat de pendelstroom de ontwikkeling van de regionale arbeidsmarkt zou bedreigen, werd de nationale overheid geacht maatregelen te nemen om deze in te dammen. In 1970 berichtten de kranten bijvoorbeeld over een televisie-uitzending van de actualiteitenrubriek Panoramiek waarin Nederlandse werkgevers en vakbonden en Limburgse autoriteiten en politici stelden dat de 'toenemende pendel een van de oorzaken is dat de sociale en economische herstructurering van Zuid-Limburg [...] gevaar loopt'. Daarbij drongen zij aan op een onderzoek naar de motieven van de grensarbeiders om na te gaan hoe het werken in Duitsland kon worden tegengegaan..$^{71}$

Uit de berichtgeving komt een beeld naar voren van nationale bewindslieden die 'het pendelprobleem' bagatelliseerden of op ambivalente wijze benaderden. ${ }^{72}$ Journalisten stelden dat de regeringsverantwoordelijken 'de pendelproblematiek niet al te zwaar in[zagen]'. Twee dagen na de Panoramiek-uitzending wilden minister Nelissen en staatssecretaris Van Son van Economische Zaken bijvoorbeeld niet verklaren dat de pendel de werkgelegenheidssituatie in (Zuid-)Limburg aantastte. De groei van het aantal arbeidsplaatsen in de provincie zou namelijk groter zijn dan de arbeidsstromen naar Duitsland. Zij gaven aan nog alle vertrouwen te hebben in de goede afloop van de herstructurering en verwachtten dat de 'zuigkracht van de Duitse lonen op Limburgse werknemers' gelijk zou blijven of zelfs zou afnemen. ${ }^{73}$ Daarnaast en daarmee samenhangend zou de Nederlandse regering onvoldoende oog hebben voor de manier waarop de grenspendel de problemen op de regionale arbeidsmarkt verhulde. Zij zou zich door de lage werkloosheidscijfers laten misleiden en daardoor geen aanvullende maatregelen nodig vinden om de regionale arbeidsmarkt een extra impuls te geven. ${ }^{74}$

$\mathrm{Na}$ enig aandringen gaf een interdepartementale werkgroep van de ministeries van Sociale en Economische Zaken het Nederlands Economisch Instituut (NEI) in 1971 opdracht de Duitslandpendel nader te onderzoeken. Deze studie zou een van de pijlers moeten vormen

68 Zie bijv. LD, 26-8-1970.

69 Dhr. Hubben tijdens een vergadering van de Kamer van Koophandel en Fabrieken van de Mijnstreek (tevens bestuurslid van SEOL en lid van de RRA), DL, 22-6-1973.

70 Zie Messing, Geschiedenis van de mijnsluiting, bijv. 305-306; zie ook LD, 24-8-1973.

71 LD, 9-11-1970.

72 Zie DNL, 14-11-1963 waarin de vraag werd gesteld of 'het probleem niet ernstig genoeg' was om 'de regering tot de uiterste krachtsinspanning te bewegen?'; LD, 10-11-1970a; DL, 17-2-1973; LD, 17-2-1973.

73 LD, 10-11-197ob. Zie ook DNL, 10-11-1970.

74 Zie bijv. de voorzitter van de NKMB, Dohmen, in DNL, 28-9-1970; Eerste Kamerlid voor de KVP, Maenen, in LD, 31-5-1972. In 1970 verwoordde minister Roolvink van Sociale Zaken en Volksgezondheid echter het standpunt dat de pendel bijdroeg aan de versluiering van de herstructureringsproblematiek (LD, 25-7-1970). Een jaar later zei hij dat er landelijk gezien weliswaar geen pendelprobleem bestond, omdat de totale uitgaande en inkomende pendel elkaar in evenwicht hielden, maar dat Limburg wel een 'zeer moeilijke last' droeg, omdat het een groot aandeel had in de uitgaande pendel (DL en LD, 4-3-1971). 
voor het vervolg op het herstructureringsbeleid in het kader van een aangekondigde 'perspectievennota'. ${ }^{75}$ De publicatie van het onderzoeksrapport liep grote vertraging op. Toen 'het pendelrapport' in de maak was, lieten Limburgse sociale partners, instanties, journalisten en uit Limburg afkomstige politici niet na de rijksoverheid te attenderen op de problemen en de dreigende 'noodsituatie' die de pendel volgens hen veroorzaakte. ${ }^{76}$ Minister Boersma van Sociale Zaken gaf in 1972 te kennen dat 'het arbeidsgebied van de provincie niet wordt begrensd door de landsgrenzen', om daar wel aan toe te voegen dat de pendel een probleem was omdat hij het arbeidsaanbod verkleinde. ${ }^{77}$ Even later sprak minister Langman van Economische Zaken zijn zorgen uit over de relatie tussen de herstructurering van Zuid-Limburg en de groeiende pendelstroom. Hij stelde dat hiermee rekening zou worden gehouden bij de besluitvorming over de laatste mijnsluitingen..$^{78}$ Desondanks bleven gerichte maatregelen uit.

Toen 'het pendelrapport' in 1973 verscheen, deed het veel stof opwaaien in de regionale pers. De onderzoekers van het NEI concludeerden onder meer dat Limburg door schaalvergrotingsprocessen één arbeidsmarkt was gaan vormen met de aangrenzende Duitse en Belgische gebieden. Dat zou zich uiten in de grote Duitslandpendel. Op basis van deze conclusie wierp het NEI de vraag op of het nog wel verantwoord was nog meer overheidsgeld te steken in de stimulering van de (Zuid-)Limburgse economie en arbeidsmarkt. ${ }^{79}$ Het rapport werd vernietigend beoordeeld. Er verschenen artikelen met koppen als 'Tweederde pendelrapport volstrekt onaanvaardbaar' en 'Regionale Raad [RRA] kraakt pendelrapport'.$^{80}$ Een lid van een Kamercommissie die het rapport begin juni besprak, stelde dat het NEI zich 'op zeer glad ijs' begaf door de regionale stimuleringsregelingen voor Zuid-Limburg ter discussie te stellen. Stopzetten van deze subsidies zou Zuid-Limburg in een 'dwangpositie' brengen waarin de bevolking moest pendelen of migreren om werk te vinden. Het overheidsbeleid kon in zijn ogen 'niet gericht zijn op 'handhaving' van de bestaande pendel' ${ }^{81}$ Volgens het Limburgse KVPKamerlid Bremen zou het NEI 'het herstructureringsbeleid aan het buitenland overlaten' en vergat het de 'eigen verantwoordelijkheid van de regering voor een evenwichtige spreiding van wonen en werken'. ${ }^{82}$ Ook anderen wezen op de tekortkomingen van het rapport en de plicht van de nationale overheid om de problemen die de pendel zou veroorzaken aan te pakken. ${ }^{83}$

De reacties op het NEI-rapport duiden op botsende visies op de ontwikkeling van de regionale arbeidsmarkt. Volgens het NEI maakte Limburg in het begin van de jaren 1970 deel uit

75 Zie LD, 12-1-1973; LD, 1-6-1973.

76 Bijv. Eerste Kamerlid van de KVP, Maenen, in LD, 31-5-1972; de districtsvoorzitter van de Unie BLHP, Franssen (tevens EK-lid namens de KVP), in LD 2-6-1972; Limburgse Eerste Kamerleden van de KVP Maenen, Horbach (tevens secretaris van de KvK Maastricht e.o. en secretaris van de RRA) en Franssen (tevens districtsvoorzitter van de Unie BLHP) in LD, 17-11-1972; LD 8-12-1972; het Industrieschap Oostelijke Mijnstreek, in DL 30-3-1973.

77 DL, 31-5-1972.

78 DL, 8-6-1972.

79 DL, 5-6-1973; zie ook Van den Berg et al., De grenspendel in Limburg, 134-138. Hoewel de Raad voor het Midden- en Kleinbedrijf in de eerste helft van de jaren 1960 tot een vergelijkbare constatering kwam, kreeg dat dan ook amper aandacht en helemaal geen kritiek in de pers (DNL, 29-4-1964; zie ook een journalist in DNL, 22-3-1961; Raad voor het MKB, Rapport inzake de gevolgen van het vrije verkeer, 24-25).

8o DL, 18-6-1973; DL, 19-6-1973 (in opdracht van de RRA had het ETIL het pendelrapport eerder kritisch onder de loep genomen. Het negatieve oordeel van het ETIL werd rechtstreeks door de RRA overgenomen (zie LD, 7-6-1973; zie ETIL, Samenvatting en kanttekeningen).

81 Voorzitter Tweede Kamercommissie 'belast met de voorbereiding van de behandeling van de nota's over het Noorden, Zuid-Limburg en nota spreiding rijksdiensten', Wierenga (zelf afkomstig uit het noorden van Nederland) in DL, 9-6-1973.

82 Ibidem.

83 Bijv. dhr. Hubben tijdens een vergadering van de Kamer van Koophandel en Fabrieken van de Mijnstreek (tevens bestuurslid van SEOL en lid van de RRA), in DL, 22-6-1973. 
van een grensoverschrijdende arbeidsmarkt. Die constatering zou als uitgangspunt moeten gelden voor het toekomstige regionaal-economische beleid. Andere partijen, zoals uit Limburg afkomstige Kamerleden en vertegenwoordigers van Limburgse instanties, konden zich daar niet mee verenigen. Een zelfvoorzienende arbeidsmarkt binnen de Nederlandse grens was voor hen de norm. Er werd een appèl gedaan op de regering om bij nieuw regionaal beleid rekening te houden met de nadelen van de Duitslandpendel voor (Zuid-)Limburg en dus haar stimuleringsbeleid voort te zetten. ${ }^{84}$ De discussie over 'het pendelrapport' bloedde snel dood toen de situatie na de oliecrisis van 1973 drastisch wijzigde. In zes jaar tijd kromp het aantal grensarbeiders van bijna 17.000 tot iets minder dan 7.000 personen in $1979 .{ }^{85}$

In de jaren 1960 en 1970 trof de nationale overheid dus geen maatregelen specifiek gericht op het terugdringen van de pendel naar Duitsland. Zij gaf aan geen mogelijkheden te zien 'de pendelproblematiek' op korte termijn op te lossen. Daarvoor gaf zij twee redenen. Op de eerste plaats zou overleg met de Duitse regering weinig effect hebben aangezien 'beide regeringen geen vat hebben op het bedrijfsleven in de grensstreken'. ${ }^{86}$ Tevens zou de Duitse regering bij het veranderen van wetgeving geen rekening houden met de grenspendel. Zo besloot zij in 1970 werkzaamheden in het weekend niet langer te belasten, wat het werken in Duitsland alleen maar aantrekkelijker zou maken ${ }^{87}$ Op de tweede plaats wezen bewindslieden geregeld op de onmogelijkheid en onwenselijkheid om de pendel een halt toe te roepen in Europees verband. ${ }^{88}$ Duitse autoriteiten, warme voorstanders van de grenspendel om het nationale werknemerstekort te verkleinen, betitelden pogingen om de grenspendel in te perken in dit licht als 'anachronisme[n]'. ${ }^{89}$

\section{'Groeipijnen van de wordende Europese eenheid'9。}

Naast Nederlandse werden Europese autoriteiten in deze periode verantwoordelijk gehouden voor 'de pendelproblematiek'. In het Verdrag van Rome uit 1957 was onder meer het streven naar een vrij verkeer van werknemers vastgelegd. Deze ambitie werd niet altijd toegejuicht in de Limburgse pers..$^{91}$ In het begin van de jaren 1960 stelde een journalist van De Nieuwe Limburger dat het verdwijnen van de belemmeringen voor het personenverkeer allerlei kansen in zich droeg, maar dat de industriële expansie van Limburg werd geremd door de grote en eenzijdige arbeidsstromen naar Duitsland. Limburg zou er niet bij gebaat zijn als het door de aantrekkingskracht van de hoge Duitse lonen 'in een windstille hoek' van 'een welvarend gebied zonder grenzen' zou komen te liggen. De journalist herhaalde daarbij de woorden van een

84 Gedeputeerde Staten in een brief aan de nieuwe premier Den Uyl in DL, 15-6-1973; de RRA in een brief aan de Ministerraad in DL, 5-10-1973.

85 Zie ook hoofdstuk 4 .

86 LD, 10-11-197ob; de minister van Sociale Zaken gaf in het begin van de jaren 1960 ook al aan overleg te hebben gevoerd met zijn Duitse collega maar hij verwachtte er 'geen al te grote resultaten' van (zie DNL, 17-10-1963).

87 Limburgse werkgever in LD, 30-10-1970; Tweede Kamer- en Europees parlementslid Berkhouwer en (de uit Limburg afkomstige) Oele van de PvdA in LD en DNL, 18-11-197ob.

88 Zie minister Roolvink van Sociale Zaken en Volksgezondheid in Limburgs Dagblad, 25-7-1970 en in LD, 25-11-1969). Zie ook DBA in DNL en LD, 30-1-1963.

89 Minister Riemer van Economische Zaken van de deelstaat NRW in DNL en LD, 9-2-1971 (op basis van artikel in Ruim Zicht (het blad van het NKV)). Verder sprak de burgemeester van Aken zich bijvoorbeeld uit voor de grenspendel in het kader van de grensoverschrijdende sociale integratie (DNL, 2-4-1971).

90 Gedeputeerde Staten van Limburg, LD, 8-1-1974.

91 Bijvoorbeeld voorzitter van de KAB Limburg, Maenen, in DNL, 14-9-196o; Limburgse Katholieke Werkgeversvereniging in LD, $11-6-1964$. 
vertegenwoordiger van het Economisch Technologisch Instituut Limburg (ETIL): 'Het provinciale hemd is nu eenmaal nader dan de internationale rok'. ${ }^{92}$

In 1968 werd het vrij verkeer van werknemers verder verankerd in Europese wetgeving. Op grond daarvan werden de werkvergunningen twee jaar later afgeschaft. Dat jaar stelde de secretaris van de Kamer van Koophandel en Fabrieken van Maastricht:

De hele ellende is, dat in de EEG de arbeidersmarkt verder geïntegreerd is dan de sociale en fiscale politiek. Daar worden we in grensland Limburg de dupe van. En ik zie de mogelijkheid niet op korte termijn tot een harmonisatie van lonen en andere arbeidsvoorwaarden en van de fiscale wetgeving in de EEG. ${ }^{93}$

In feite zou de EEG met het vrij verkeer voor werknemers te zeer vooruitlopen op de harmonisering van de sociale en fiscale wet- en regelgeving van de lidstaten. Zo lang daar geen sprake van was, zou er tussen de (Zuid-)Limburgse arbeidsmarkt en die van het aanpalende Duitse gebied 'oneerlijke concurrentie' blijven bestaan. ${ }^{94}$ Een journalist vertolkte een vergelijkbare opvatting en voegde daaraan toe dat 'wij [Limburgers] voortdurend met de dreiging [leven], dat het ene land op ongezonde wijze het andere blijft leegzuigen' ${ }^{95}$ De pendelstroom zou dan te groot blijven, waardoor de afhankelijkheid van de Duitse economie werd gehandhaafd. In dit verband bekritiseerde de directeur van een nieuw te openen bedrijf in Limburg ook de genoemde 'eenzijdig afgekondigde' Duitse belastingvrijstelling uit 1970. Hij was van mening dat de EEG moest ingrijpen om deze terug te draaien. ${ }^{96}$

Harmonisatie van sociale en fiscale wet- en regelgeving werd als het middel beschouwd om het pendelprobleem op te lossen. ${ }^{97}$ De gedachte was dat als deze maar gelijk waren, het voor de Limburgers veel minder aantrekkelijk zou zijn om de grens over te steken..$^{8}$ De institutionele grens moest dus in feite worden uitgevlakt om de beroepsbevolking binnen te houden. Men realiseerde zich echter dat een dergelijke harmonisering 'een zaak van lange adem' zou worden. ${ }^{99}$ Daarom werden behalve landelijke, ook Europese autoriteiten aangezocht de regionale economische ontwikkeling te stimuleren. Tot twee maal toe trachtten Gedeputeerde Staten van Limburg de Europese Commissie ertoe te bewegen hen financiële steun te verlenen. ${ }^{100}$ In 1974 probeerden zij aanspraak te maken op de middelen uit het Europees Regionaal Fonds, want:

Het zijn juist de grensgebieden die de groeipijnen van de wordende Europese eenheid het heftigst ervaren en dus ook het recht hebben op een spoedige en wellicht ook een bijzondere behandeling. ${ }^{101}$

92 DNL, 16-5-1962. Het ETIL is een onderzoeksinstituut dat in 1932 is opgericht om de industriële belangen van de provincie Limburg te bevorderen (Messing, Geschiedenis van de mijnsluiting, 262). Tegenwoordig is het een onafhankelijk regionaal-economisch onderzoeks- en adviesbureau (http://www.etil.nl/).

93 Dhr. Horbach (tevens Eerste Kamerlid namens de KVP en secretaris van de RRA), in DNL, 3-10-1970.

94 Industrieschap Oostelijke Mijnstreek in LD, 26-11-1970a.

95 DNL, 12-11-1970.

96 LD, 30-10-1970.

97 Zie bijvoorbeeld DBA in LD 3-2-196o; voorzitter van de KAB in Limburg, Maenen, in DNL, 13-9-196o en 14-9-1960 (Maenen als Tweede Kamerlid voor de KVP in LD 10-3-1971); Gedeputeerde Staten van Limburg in DL, 15-6-1973; Kamer van Koophandel en Fabrieken in de Mijnstreek in DL, 22-6-1973; RRA in LD, 10-8-1973.

98 DNL, 1-5-1970; DNL, 12-11-1970; Industrieschap Oostelijke Mijnstreek in LD, 26-11-1970a; Limburgs Tweede Kamerlid voor de KVP, Maenen, in LD, 10-3-1971; het NEI in LD, 5-6-1973.

99 NEI in DL, 5-6-1973; zie bijvoorbeeld ook de voorzitter van de KvK in Venlo in LD, 9-1-1971 en dhr. Hubben tijdens een vergadering van de Kamer van Koophandel en Fabrieken van de Mijnstreek (tevens bestuurslid van SEOL en lid van de RRA), in DL, 22-6-1973. 100 In het najaar van 1970 en in het voorjaar van 1974.

101 Gedeputeerde Staten in een brief aan de ministerraad in LD, 8-1-1974. 
Hoewel de Europese Commissie in het begin van de jaren 1970 nog wel aangaf enigszins bezorgd te zijn over de situatie in Zuid-Limburg, ventileerde zij in 1974 een andere opvatting over grensoverschrijdende arbeidsmobiliteit:

Binnen een gemeenschappelijke markt met een vrij verkeer van werknemers is er [...] in beginsel geen wezenlijk verschil tussen de grensoverschrijdende en de binnenlandse pendel. ${ }^{102}$

Hier zien we het nationaal begrensde betekeniskader van de Limburgse autoriteiten contrasteren met het 'ontgrensde' denken van de Europese autoriteiten. In de volgende paragraaf zal blijken dat dit laatste vanaf het einde van de jaren 1970, maar vooral vanaf het begin van de jaren 1990, ook in Limburg gemeengoed werd.

\section{DEFINITIE VANUIT EEN ONTGRENZEND REFERENTIEKADER}

Aan het einde van de jaren 1970 maakte de eerdere afkeuring van de grenspendel plaats voor instemming. Dat uitte zich eerst in aanvaarding, die vanaf het begin van de jaren 1990 samenging met een verwelkoming van de grenspendel naar Duitsland. Desalniettemin werd er in deze periode nog gesproken over 'de pendelproblematiek'. Verwijzingen naar nadelige effecten voor de nationale en de regionale economie verdwenen evenwel als sneeuw voor de zon. In eerste instantie richtte de aandacht zich vrijwel volledig op de financiële nadelen die de grensarbeiders ondervonden van de afwijkende nationale systemen van wet- en regelgeving. De betrokkenheid bij hun financiële wel en wee is symptomatisch voor de acceptatie van de grenspendel. In de jaren 1990 werd daaraan toegevoegd dat de aanhoudende moeilijkheden de grensoverschrijdende arbeidsmobiliteit in de weg zouden staan, terwijl de grenspendel een gunstige bijdrage zou leveren aan de regionale economische ontwikkeling. In tegenstelling tot eerdere decennia werd hij nu vanuit regionaal perspectief toegejuicht. De veranderende beoordeling van de grensoverschrijdende arbeidsstromen kwam voort uit een nieuwe 'ontgrenzende' conceptie van Zuid-Limburg als grensgebied.

\section{Van acceptatie naar verwelkoming}

'Verlos pendelaar van onrechtvaardigheden'103

Vanaf het einde van de jaren 1970 tot de jaren 1990 was er betrekkelijk weinig aandacht voor de grenspendel in de Limburgse pers. Wanneer erover werd bericht betrof het vrijwel uitsluitend de nadelige financiële consequenties die de grensarbeiders ondervonden van de afwijkende sociale en fiscale wet- en regelgeving aan weerszijden van de grens. Op basis van het Nederlands-Duitse belastingverdrag uit 1959 en de Europese verordening 1408/71 vielen zij gedurende de periode die ze in Duitsland werkten, onder het Duitse fiscale en sociale stelsel. Zodra zij echter stopten met werken, of wanneer zij en/of hun partner ook in Nederland inkomen genoten, vielen zij tegelijkertijd onder twee regimes. Door discrepanties tussen het Nederlandse en het Duitse systeem konden de grensarbeiders op verschillende punten tussen 
de wal en het schip vallen. ${ }^{104}$ Hoewel dit in de jaren 1960 en het eerste deel van de jaren 1970 waarschijnlijk niet anders was, stond het destijds amper in de publieke belangstelling, al werd in 1972 in het Limburgs Dagblad geconstateerd dat de grensarbeiders te veel belastinggeld afdroegen. Dat werd echter vooral als probleem gezien omdat het de bestedingen in Limburg zou drukken, en niet omdat het de grensarbeiders zelf op kosten joeg. ${ }^{105}$ Tot het einde van de jaren 1970 heerste de gedachte dat de grensarbeiders baat hadden bij de nationale systeemverschillen, met name gegeven de hogere lonen in Duitsland, terwijl de (Zuid-)Limburgse en de Nederlandse economie er nadeel van ondervonden.

Aan het einde van de jaren 1970 kantelde dit beeld. Vanaf dat moment werd gewezen op de financiële verliezen die de grensarbeiders leden als gevolg van verschillen tussen de nationale sociale en fiscale stelsels. Datwerd als buitengewoon onrechtvaardig beschouwd. Rond 1980 speelde een aantal problemen. Niet alleen de grensarbeiders, die nog altijd te veel belasting afdroegen, ${ }^{106}$ maar ook de ex-grensarbeiders werden getroffen door de verschillen in wet- en regelgeving. Zo moesten arbeidsongeschikt verklaarde grensarbeiders in Nederland zowel werknemers- als werkgeverspremie afdragen voor een aantal volksverzekeringen. Voor 1 januari 1982 dienden zij alle achterstallige betalingen te voldoen. ${ }^{107}$ Deze thematiek bleef op de politieke agenda en daardoor in de dagbladen terugkeren, totdat staatssecretaris Linschoten van Sociale Zaken in 1994 besloot de afgedragen premies met terugwerkende kracht aan alle gedupeerden terug te betalen. ${ }^{108}$ Andere problemen hielden aan, of er deden zich nieuwe voor door aanpassingen van weten regelgeving op sociaal en fiscaal gebied. Grensarbeiders vielen daarbij vaak buiten de boot. ${ }^{109}$

Terwijl zij enkele jaren daarvoor nog faliekant tegen de pendel waren, toonden Limburgse politici van de KVP, en haar opvolger het Christen Democratisch Appèl (CDA), zich vanaf het einde van de jaren 1970 buitengewoon ontstemd over het onrecht dat de Duitslandgangers werd aangedaan. Zij spraken over discriminatie van grensarbeiders ten opzichte van degenen die in hun woonland werkten. In hun ogen diende grensarbeid gelijk te staan aan werk binnen de nationale grenzen. Blijkbaar zagen zij in de grenspendel niet langer een gevaar dat bestreden moest worden. Diverse Limburgse christen-democratische politici namen het in de Tweede Kamer en het Europees Parlement dan ook op voor de grensarbeiders. ${ }^{10}$ Daarnaast

104 Van Dam en De Grip, De Euregionale arbeidsmarkt, 22-23; Commissie grensarbeiders, Rapport van de Commissie grensarbeiders.

105 Een Limburgse verzekeringsinspecteur in LD, 5-9-1972. Verder werd in 1970 opgemerkt dat de grensarbeiders geen kindergeld ontvingen voor hun eerste kind, maar dat dit niet zou opwegen tegen alle voordelen die de grenspendel bood (LD, 9-7-1970). Ook organiseerde de metaalbewerkersbond St. Eloy (zoals eerder aangegeven) met haar Belgische evenknie in 1971 een bijeenkomst waarbij naar Duitsland forensende metaalbewerk(st)ers werden geïnformeerd over hun sociale positie en werden opgeroepen lid te worden (zie LD, 20-1-1971; DNL, 21-1-1971; DNL, 25-1-1971).

106 Overigens werd er in 1980 een 'Aanvullend Protocol' aan het Nederlands-Duitse belastingverdrag van 1959 toegevoegd om ervoor zorg te dragen dat de grenspendelaars voor dezelfde tegemoetkomingen in aanmerking zouden komen als de inwoners van het werkland (hieraan waren echter wel voorwaarden verbonden) (Van Dam en De Grip, De Euregionale arbeidsmarkt, 14).

107 Bijv. LD, 6-11-1981. Zie ook Sociale Verzekeringspositie van grensarbeiders, 11.

108 Zie bijv. de Limburgse CDA-Kamerleden Van der Linden, Oomen en Franssen en PvdA-Kamerlid Wöltgens in LD, 19-2-1982; CDA-Kamerlid Oomen in DL, 7-3-1985 en LD, 14-4-1988; over de beslissing van staatssecretaris Linschoten, zie DL en LD, 28-12-1994. Sinds 1 juli 1989 waren de voormalige grensarbeiders vrijgesteld van premie. Destijds konden zij binnen een jaar om teruggave vragen. Degenen die te laat waren, konden nergens meer aanspraak op maken. Dat werd door Linschoten teruggedraaid door de afgedragen premie met terugwerkende kracht aan alle grensarbeiders terug te betalen.

109 Zo zou de introductie van de Duitse Steuersenkungsgesetz en de Nederlandse energieheffing de grensarbeiders benadelen, terwijl deze juist financieel voordeel moesten opleveren (zie resp. LD, 6-1-1986 en DDL, 30-5-1998).

110 Over de fiscale problemen: zie de Limburgse Tweede Kamerleden Notenboom en Van der Linden in LD en DL, 30-6-1978; Notenboom in de hoedanigheid van europarlementariër in LD, 9-5-1979. Over de dubbele premieheffing voor onder meer de AOW: zie LD, 17-2-1982 en LD,19-2-1982. Verder werd er in de jaren daarna bijvoorbeeld gewezen op problemen rond de ziektekostenverzekering van de gezinsleden (zie het Limburgse CDA-Kamerlid Oomen in DL, 7-3-1985), de verschillende normen voor het vaststellen van arbeidsongeschiktheid (zie DL, 30-3-199o), de korting op de AOW-uitkering van echtgenotes/n van grensarbeid(st)ers (zie het Limburgse CDA-Kamerlid Stroeken, 1-2-2001), en het uitblijvende recht op hypotheekrenteaftrek (DDL, 2-2-2001). 
vormde de situatie rondom de dubbele premieheffing onder ex-grensarbeiders aanleiding om in 1981 samen met vertegenwoordigers van vakbonden, grensarbeiders en regionale instanties, een commissie op te richten om (ex-)grensarbeiders te informeren en adviseren over hun rechten en plichten. Het CDA achtte dit noodzakelijk aangezien deze personen 'zich niet kunnen verweren, omdat zij geen enkel inzicht hebben in wat krachtens nationale en buitenlandse wetgevingen is verschuldigd en niet-verschuldigd. ${ }^{{ }^{111}}$ De grensarbeiders zouden de dupe zijn van de slechte aansluiting tussen de Nederlandse en de Duitse fiscale en sociale stelsel en van hun gebrek aan inzicht in hun positie daarin.

Ook Nederlandse vakbonden participeerden in de CDA-commissie. Waar zij voorheen meestal buitengewoon negatief waren over de Duitslandpendel, ontpopten ook zij zich nu als belangenbehartigers van de grensarbeiders. Zo zetelde ook een bestuurslid van de grootste Nederlandse vakbond, de Federatie Nederlandse Vakbeweging (FNV), in de Sociale Verzekeringsraad die de regering in het begin van de jaren 1980 moest adviseren over de dubbele premieverplichting van ex-grensarbeiders. ${ }^{12}$ Zij zei de staatssecretaris van Financiën hierop te zullen aanspreken om 'een dreigende ramp af te wenden' en werd daarin gesteund door haar mederaadsleden. ${ }^{13}$ Het nieuwe vakbondsstandpunt ging hand in hand met de internationalisering van de vakbeweging. In 1973 waren de nationale bonden al nauwer gaan samenwerken in het Europees Verbond van Vakverenigingen (EVV). ${ }^{114}$ Vijf jaar later werd in de EMR de Interregionale Vakbondsraad (IVR) opgericht met het specifieke doel 'op de bres' te springen voor de grensarbeiders. ${ }^{115}$ Dat was een breuk met het verleden. Waar de vakbonden voorheen in de berichtgeving alleen leken op te komen voor de belangen van de in eigen land actieve arbeidskrachten gaf de IVR te kennen een einde te willen maken aan 'een aantal misstanden waarmee de pendelaars geconfronteerd' werden. ${ }^{116}$ Diverse malen deden de kranten verslag van de inzet van de EVV en de IVR ten behoeve van de grensarbeiders. Zo besprak het Europees Parlement in 1981 een resolutie van de Franse Europarlementariër Oehler, die grotendeels was gebaseerd op een 'grensgangersmemorandum' van de EVV, en een einde zou moeten maken aan de 'onrechtvaardigheden' waar de grensarbeiders mee te maken hadden. ${ }^{17}$ Enkele jaren later besteedde het Limburgs Dagblad aandacht aan een rapport van de IVR over de financiële problemen die grensarbeiders ondervonden als gevolg van de afwijkende nationale regimes. ${ }^{118}$

In de commissie (ex-)pendelaars van het CDA zetelde verder een vertegenwoordiger van de Vereniging Europese Grenslandbewoners (VEG). Deze belangenorganisatie werd in 1979 opgericht in reactie op de moeilijkheden die op dat moment speelden als gevolg van de systeemverschillen. ${ }^{119}$ Ook de VEG trachtte de aandacht te vestigen op de financiële problemen waarmee veel grensarbeiders zich geconfronteerd zagen. Daarbij ging zij krachtig taalgebruik niet uit de weg. Ze noemde grensarbeiders bijvoorbeeld 'vogelvrijverklaarden' die werden 'be-

111 LD, 29-10-1981; zie ook LD, 6-11-1981. Hieraan werd ook wel gerefereerd als de 'actiegroep ex-pendelaars' (LD, 6-9-1982).

112 Hierin waren vertegenwoordigers van de rijksoverheid, en de werknemers- en werkgeversorganisaties vertegenwoordigd. De FNV was in 1976 voortgekomen uit een fusie van het NVV en het NKV.

113 Bestuurslid van de FNV, Clerx, in LD, 19-2-1982; later zou het advies van de SVR tegenvallen voor de grensarbeiders: zie LD, 175-1986.

114 Eerder werd er samengewerkt in een Europese Secretariaat binnen het Internationale Verbond van Vrije Vakverenigingen (zie Baum, 'The European Trade Union Confederation', 335-336).

115 DL, 15-2-1979; de EVV richtte in verschillende grensgebieden deze Interregionale Vakbondsraden op (zie Commissie van de Europese Gemeenschappen Mededeling van de Commissie inzake de levens- en arbeidsvoorwaarden, 21.

116 DL, 15-2-1979.

117 LD, 30-9-1981.

118 Idem, 24-5-1985.

119 Zie VEG, '25jaar VEG', 6. 
straft' voor het werken in Duitsland. ${ }^{120}$ Tijdens een verkiezingsbijeenkomst van het CDA in 1982 sprak een vertegenwoordiger van de VEG over de financiële 'nood' onder ex-grensarbeiders die dubbele premies betaalden. Hij wees er samen met een lid van de CDA-commissie op dat deze soms dermate 'hoog gestegen' was en dat zij 'hondenbrokken moe[s]ten kopen om hun kinderen toch wat vlees te geven' ${ }^{121}$

Was de teneur van de berichtgeving tot in de tweede helft van de jaren 1970 nog dat de grensarbeiders baat hadden bij de systeemverschillen, nu lag het accent op de nadelen die zij ervan ondervonden en hoe oneerlijk dat was. Deze nieuwe definitie van 'het pendelprobleem' getuigt van een fundamentele omslag in het vertoog over de arbeidsmobiliteit naar Duitsland. Er werd niet langer gewezen op risico's die de grensarbeiders zelf namen, maar vooral op de als onrechtvaardig betitelde nadelige effecten van systeemverschillen. Deze definitie van het pendelprobleem wijst op een acceptatie van de grenspendel.

Deze kentering trad op in een context waarin de pendel sterk was gekrompen, de (ex-) grensarbeiders zich met een aantal prangende problemen geconfronteerd zagen en mede in reactie daarop een belangenvereniging oprichtten, en de vakbeweging internationaal ging samenwerken. Belangrijker was echter dat er een wijziging optrad in de betekeniskaders met betrekking tot Zuid-Limburg als grensgebied. De internationale samenwerking van de vakbonden is symptomatisch voor het loslaten van de nationale kaders, dat gepaard ging met een verschuivende conceptie van Zuid-Limburg als grensgebied. Gedurende de internationale economische crisis die in 1973 inzette, verloren de gedachten terrein dat het mogelijk was de regionale economie af te schermen van buitenlandse invloeden en dat overheidsingrijpen zaligmakend was. Onder deze omstandigheden veranderde het referentiekader met betrekking tot Zuid-Limburg als grensgebied en dat had consequenties voor de manier waarop er tegen de grenspendel werd aangekeken. De nieuwe denkwijze manifesteerde zich in de Concept perspectievennota Zuid-Limburg uit $1977 .{ }^{122}$

In de Concept perspectievennota formuleerde een commissie bestaande uit vertegenwoordigers van nationale en provinciale overheden een voorstel voor het vervolg op het herstructureringsbeleid in het kader van de mijnsluitingen. De nota was reeds in het begin van de jaren 1970 aangekondigd, maar de totstandkoming ervan had nogal wat voeten in de aarde. Het oponthoud werd mede veroorzaakt door onenigheid over de bepaling van een standpunt ten aanzien van de grenspendel. ${ }^{123}$ Omdat deze zo omstreden was, kreeg het NEI in het midden van de jaren 1970 opnieuw opdracht een rapport te schrijven, dit keer specifiek over de gevolgen van de Duitslandpendel voor het Herstructureringsgebied, oftewel voor Zuid-Limburg. Het NEI concludeerde onder meer dat de pendel nauwelijks een rol speelde bij de achterblijvende werkgelegenheidsontwikkeling in het gebied. ${ }^{124}$ De commissie die belast was met het opstellen van de Concept perspectievennota nam dit standpunt over. De ironie wil dat zij daarbij wel kort verwees naar de mogelijke rol die de negatieve publiciteit rond de Duitslandpendel

120 Bestuurslid van de VEG, Debets, in DL, 5-3-1987; DDL, 10-11-1998.

121 Voorzitter van de VEG, Koch, en lid van de 'actiegroep ex-pendelaars' (oftewel de CDA-commissie (ex-)grensarbeiders, Trees, in $\mathrm{LD}, 6-9-1982$.

122 Zie ook de scriptie van Vreuls, Grensoverschrijdende pendel, 5 6; hij wees tevens op het 'Ontwerp Streekplan Zuid-Limburg', maar gaf daarbij helaas geen jaartal weer.

123 Derix, Perspectief voor Limburg, 40, 78; in 1973 stelden Gedeputeerde Staten bijvoorbeeld zelf nog 'dat in de perspectievennota beleidsmaatregelen aangekondigd moeten worden, die erop gericht zijn de grote eenzijdige pendel in Limburg terug te dringen' (eenzijdig verwijst er hier naar dat er amper Duitsers in Limburg werkten) (DL, 15-6-1973).

124 Hendriks et al., De gevolgen van de pendel op Duitsland, 13, 26-27. 
daarbij had gespeeld. Voorts wees de commissie op de conjunctuurgebondenheid van de pendel, maar verwachtte zij tegelijkertijd dat de in 1975 overgebleven grensarbeiders een harde kern vormden, en dat de pendelstroom in de jaren daarna weer licht zou groeien. Zij kwam tot de slotsom dat de grenspendel geaccepteerd diende te worden, omdat hij bijdroeg aan het beperken van de werkloosheid en omdat de mogelijkheid tot pendel naar Duitsland inmiddels een 'integrerend bestanddeel' van de Zuid-Limburgse arbeidsmarkt vormde. ${ }^{125}$ Het zou in haar ogen echter niet alleen onmogelijk en onnodig, maar gezien het Europese integratieproces tevens onwenselijk zijn de Duitslandpendel af te remmen. Daarnaast riep de commissie op tot aandacht voor 'de problemen die de individuele pendelaar in bepaalde opzichten ondervindt'. ${ }^{126}$

Werk in Duitsland werd daarmee gelijkgesteld aan werk binnen Zuid-Limburg. Na een inspraakprocedure waarin enige bezwaren werden geuit tegen het omvangrijke en eenzijdige karakter van de pendelstroom tussen Zuid-Limburg en Duitsland, besloot de regering in de uiteindelijke Perspectievennota van 1978 vast te houden aan het pendelstandpunt van de opstellers van de Concept perspectievennota. Staatssecretaris De Graaf van Sociale Zaken kwalificeerde grensarbeid een jaar later als 'passend werk'. ${ }^{127}$ In de Perspectievennota tekende de regering wel aan dat de pendel inmiddels sterk was afgenomen en benadrukte zij dat ze zich 'niet ontslagen acht[te] van de plicht al het mogelijke te doen om arbeidsplaatsen in het Herstructureringsgebied [te scheppen]' ${ }^{128}$

Gedurende de totstandkoming van de Perspectievennota vond dus een ommekeer plaats in het denken over de grenspendel. Het werd niet langer als een probleem beschouwd dat een deel van de bevolking in Duitsland werkte. Impliciet betekende dit dat enige afhankelijkheid van het buurland werd aanvaard. Zuid-Limburg hoefde niet langer een autonome economische regio te zijn ten opzichte van het aangrenzende buitenland. Hoewel er in de krantenartikelen niet direct aan de acceptatie van de grenspendel in de (Concept) Perspectievennota werd gerefereerd, schemerde de daarin verwoorde gedachtegang er wel duidelijk in door. ${ }^{129}$ Terwijl men de pendel naar Duitsland eerder in het nationaal, regionaal en het belang van de grensarbeiders wilde afremmen, achtte men het nu noodzakelijk haar te faciliteren. Er mocht immers geen onderscheid bestaan tussen degenen die in hun woonland werkten en de grensforensen. Dat sluit aan bij de in de jaren 1970 door de Europese Commissie verwoorde visie dat er in haar ogen geen verschil bestond tussen grenspendel en binnenlandse pendel. ${ }^{130}$

De acceptatie van het verschijnsel luidde het begin in van een 'ontgrenzing' van de beeldvorming rond de grenspendel, die samenging met een 'ontgrenzende' conceptie van ZuidLimburg als grensgebied. Met ingang van de jaren 1990 zou dit proces in een stroomversnelling terechtkomen.

125 Coördinatiecommissie Perspectievennota, Concept perspectievennota, 46-47, 67-69, 147-148.

126 Ibidem, 147-148.

127 DL, 27-4-1979; hij beargumenteerde dit door erop te wijzen dat 'zowel in het geval van West-Duitsland als van België de sociale voorzieningen op zijn minst 'niet zodanig minder gunstig zijn' dan in Nederland'.

128 De term eenzijdig verwijst hier zowel naar de samenstelling van de arbeidsstromen (vooral handarbeiders) als naar de richting van de arbeidsstromen (vooral naar Duitsland en weinig in omgekeerde richting); Perspectievennota Zuid-Limburg, 33-34.

129 Mogelijk zijn de artikelen waarin de grenspendel direct aan de Concept perspectievennota werd gerelateerd vanwege de selectiecriteria van de afzonderlijke archieven niet in de mappen over de grenspendel opgenomen.

130 DL, 26-4-1974. 


\section{'Arbeidsmarkt in Euregio heeft nog zijn grenzen ${ }^{131}$}

De auteurs van de Concept perspectievennota accepteerden de grenspendel en attendeerden daarnaast op de Europees gezien gunstige ligging van Zuid-Limburg. Zij noemden het gebied het 'balkon van Europa' vanwege zijn situering 'in het middelpunt van de industriële driehoek tussen de Randstad, het Ruhrgebied en het Saargebied'. ${ }^{132}$ Zuid-Limburg kwam dus in een nieuw daglicht te staan. Het werd niet langer als periferie in Nederland, maar als centrale regio in Europa gezien. Met het oog op de Europese eenwording was het volgens de opstellers van de Concept perspectievennota 'een beleidsoptie' om te streven naar een verdere integratie van de grensregio's. Om daarvan te kunnen profiteren zou de grens poreuzer moeten worden. ${ }^{133}$ De auteurs zetten daarmee de deur open voor het verwelkomen van de grenspendel. Zij wezen op grensoverschrijdende samenwerkingsverbanden die grensgerelateerde problemen trachtten te bestrijden. ${ }^{134}$ Voor Zuid-Limburg is de EMR, die een jaar voor het verschijnen van de Concept perspectievennota werd opgericht, de belangrijkste organisatie op dit gebied. Door het aanpakken van grensgebonden obstakels probeert de EMR de deelgebieden optimaal te laten profiteren van hun Europees gezien goede ligging. ${ }^{135}$

Aan het einde van de jaren 1970 en in de jaren 1980 bestond er in Zuid-Limburg nog geen geschikte voedingsbodem voor deze benadering. Tijdens de inspraakronde over de Concept perspectievennota stuitte zij kennelijk op zo veel kritiek dat in de uiteindelijke Perspectievennota een verwijzing naar de nadelige kanten van de grensligging werd opgenomen. ${ }^{1{ }^{16}}$ Ook in krantenartikelen over de grenspendel werd vooralsnog geen gewag gemaakt van de internationaal gunstige ligging van Zuid-Limburg. Men kon zich weliswaar verzoenen met het idee dat er sprake was van een zekere afhankelijkheid van het buurland, wat zich manifesteerde in de acceptatie van de grenspendel, maar het streven naar een verdergaande integratie was vooralsnog een brug te ver.

Begin jaren 1990 kwam daar verandering in. Dat had ten dele te maken met een heroriëntatie binnen het regionaal-economisch beleid. Tot het begin van de jaren 1980 bood de overheid (vaak perifere) regio's met ontwikkelingsachterstanden een steuntje in de rug. In de periode daarna kwam het accent te liggen op het benutten van regionaal ontwikkelingspotentieel, decentralisatie en werd er meer ruimte gelaten voor marktwerking. Onder het veranderend gesternte van de globaliserende economie en het integrerende Europa waarin regio's meer met elkaar gingen concurreren bij het aantrekken van investeringen en werkgelegenheid, werd de gunstige internationale ligging van Zuid-Limburg een belangrijk vestigingsvoordeel. ${ }^{137}$ Het beleid in het kader van de Perspectievennota Zuid-Limburg geldt als een van de laatste voorbeelden van het beleid gericht op het ondersteunen van achtergebleven regio's. In 1990 kwam dit beleid ten einde. ${ }^{13^{8}}$ Tegelijkertijd werd op Europees niveau gewerkt aan het openen van de grenzen in het kader van de eenheidsmarkt en kreeg de Euregionale samenwerking een nieuwe impuls met de invoering van de INTERREG-gelden van de Europese

\footnotetext{
131 Kop van artikel in LD, 24-5-1994.

132 Coördinatiecommissie Perspectievennota, Concept perspectievennota, 18, 20, 143.

133 Ibidem, 20, 49; zie ook Derix, Perspectief voor Limburg, 162.

134 Coördinatiecommissie Perspectievennota, Concept perspectievennota, 20.

135 Voor meer over de EMR: zie hoofdstuk 1 en 3.

136 Perspectievennota Zuid-Limburg, 20-21.

137 Lambooy, 'Regio's zonder grenzen'; Van Oort en Raspe, Ruimtelijkeconomisch beleid in de kenniseconomie, 6-8; over de veranderende positie van regio's in Europa zie Keating, The New Regionalism in Western Europe, o.a. 72-74. 138 Paping en Van der Meer, 'Herijking van het regionale beleid', 283.
} 
Commissie. ${ }^{139}$ In deze veranderende context ontstond er meer ruimte om Zuid-Limburg niet meer als nationale periferie, maar als centrale en dus kansrijke Europese regio te benaderen.

In de jaren 1990 traden Euregionale autoriteiten veelvuldig naar voren in de berichtgeving over de grenspendel. Zo afficheerde de EMR zich in 1990, samen met de andere vier Euregio's waarin Nederlandse en Duitse autoriteiten samenwerkten, als 'proeftuin van Europa', de plaats waar Europa concreet gestalte zou moeten krijgen. Daarbij werden de financiële problemen rond grensarbeid als problemen van de betreffende grensregio's gepresenteerd. $.^{1{ }^{10}} \mathrm{La}-$ ter stelde een vertegenwoordiger van de Euregio bij Enschede mede namens de EMR:

De problemen van de grensarbeiders op het gebied van sociale zekerheid en belastingen nemen eerder toe dan af. Dit frustreert het vrije verkeer van mensen tussen lidstaten van Europa en hindert de economische ontwikkeling in grensregio's. ${ }^{141}$

Het lot van de grensgebieden werd dus verbonden met het lot van de grensarbeider.

In deze periode kreeg het grensoverschrijdend regionalisme van de EMR ook bij anderen een voet aan de grond. ${ }^{142}$ Het uit Limburg afkomstige Tweede Kamerlid Quint van de Partij van de Arbeid (PvdA) organiseerde in 1991 een congres onder de titel 'Euregio, fictie of werkelijkheid'. Zij vertelde daarover:

Schaalvergroting is aan de orde van de dag. [...] Doe je niets, dan ben je op voorhand de grote verliezer. En dan bedoel ik niet alleen Zuid-Limburg, maar ook de regio's aan de andere kant van de grens. Dan verwordt de Euregio tot een soort periferie in het kwadraat. Leuk om een keer op vakantie te gaan, maar meer ook niet. ${ }^{143}$

Het Kamerlid verwachtte dat een grensoverschrijdende, Euregionale arbeidsmarkt een positieve uitwerking zou hebben op de regionale ontwikkeling. De grensoverschrijdende arbeidsmobiliteit, die daar een cruciaal deel van uitmaakte, zou echter worden afgeremd door de aanhoudende systeemverschillen. Om deze hindernissen weg te nemen opperde het Kamerlid om in de Euregio te experimenteren met nieuwe vormen van samenwerking op onder meer het gebied van arbeidsvoorziening en sociale wetgeving. ${ }^{144}$ Regionale instanties schaarden zich nu eveneens onder de voorstanders van de grenspendel. Zo wees de voorzitter van het Regionaal Bureau voor de Arbeidsvoorziening (RBA) er net als het PvdA-Kamerlid Quint op dat de problemen van de pendelaars opgelost moesten worden om tot een Euregionale arbeidsmarkt te kunnen komen. ${ }^{145}$

In de jaren 1990 werd er dus opnieuw een verband gelegd tussen de grenspendel en de regionale economische ontwikkeling. In tegenstelling tot de periode tot het einde van de jaren 1970 werd het werken over grenzen nu juist in het belang van Zuid-Limburg als grensgebied geacht. Grensarbeid werd niet meer alleen geaccepteerd, maar met het oog op de regionale ontwikkeling tevens toegejuicht. Overigens ging het om zowel grensoverschrijdende pendel naar het Duitse grensgebied als de andere kant op en met het Belgische grensgebied.

140 Dit was de titel van een themadag rond de vijf Nederlands-Duitse Euregio's in Den Haag, DL, 31-10-199o.

141 Hoofd Algemene Zaken van het Euregio-kantoor in Enschede, Meijer, in LD, 19-6-1997 (zie ook DDL, 19-6-1997).

142 Over grensoverschrijdend regionalisme, zie Scott, 'Euroregions Governance and Transborder Cooperation', 104-105.

143 LD, 20-11-1991.

144 Idem, 16-11-1991.

145 Voorzitter van het RBA, Frederix, in DL, 26-11-1991. 


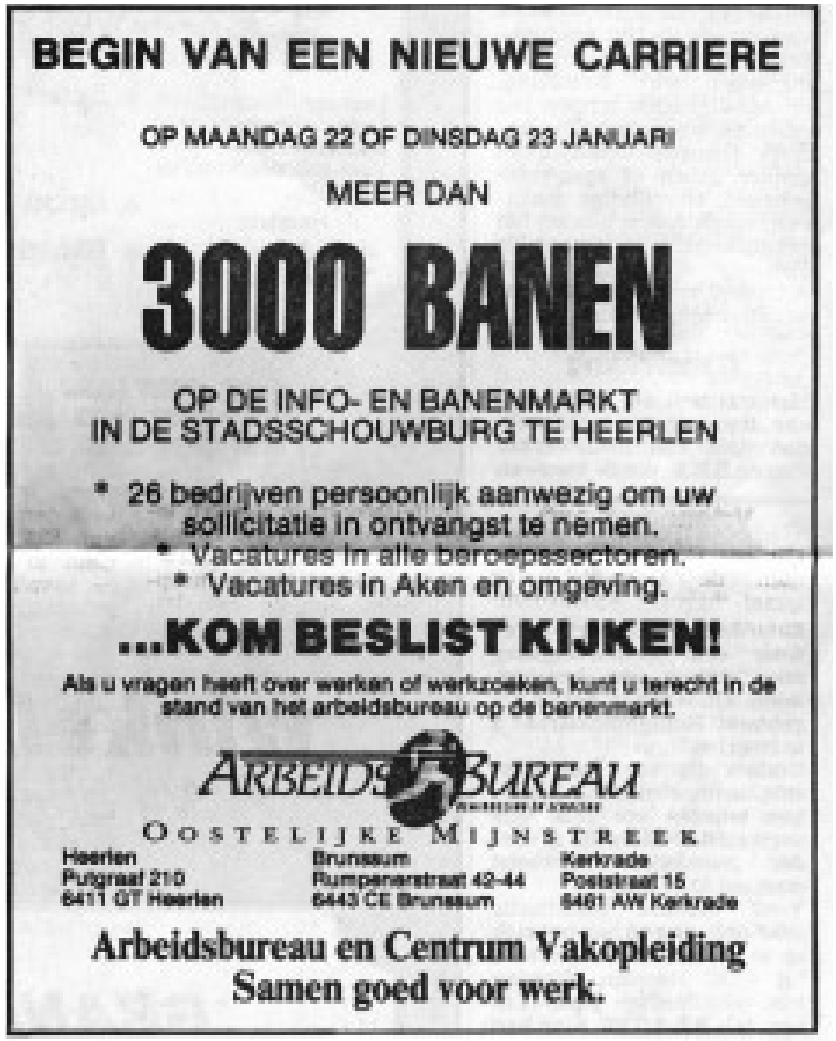

Advertentie voor een grensoverschrijdende banenmarkt. Bron: DDL, 17-1-1990 (Rijckheyt: krantenknipselmappen).

Naast de Euregionale van Limburgse autoriteiten en uit Limburg afkomstige politici, gingen de vakbonden de grenspendel nu omarmen. Aan het einde van de jaren 1970 kwamen zij reeds op voor de belangen van de grensarbeiders. Met ingang van de jaren 1990 zagen ook zij de grensoverschrijdende arbeidsmobiliteit als bijdrage aan de regionale ontwikkeling. Via de IVR onderhielden zij nauwe banden met de Euregio. In 1991 stelde de voorzitter van de FNV Limburg en de IVR, Friedrichs, dat er meer aandacht moest komen voor een gezamenlijk arbeidsmarktbeleid in de Euregio. ${ }^{146}$ Kort daarna ging de FNV in de EMR deelnemen aan het programma van de European Employment Service (Eures), dat ernaar streeft door middel van informatievoorziening en arbeidsbemiddeling grensoverschrijdende arbeidsmobiliteit te faciliteren en stimuleren. ${ }^{147}$ In 2000 betoogde de IVR dat de bevolking van de Euregio zich meer over de grens moest oriënteren bij het zoeken naar een baan. ${ }^{14^{8}}$ Dergelijke uitlatingen en activiteiten waren voor een Nederlandse vakbond in de jaren 1960 en 1970 vrijwel ondenkbaar.

In de jaren 1990 deden de Limburgse dagbladen diverse malen op positieve wijze verslag van activiteiten gericht op het stimuleren van grensoverschrijdende arbeidsmobiliteit, zoals banenmarkten georganiseerd door de lokale arbeidsbureaus en werkgevers. ${ }^{149}$ Doorgaans

148 Zij wilde medewerkers van arbeidsbureaus daarom een opleiding aanbieden waarin zij zouden leren 'laaggeschoolden te wijzen op de mogelijkheden over de grens' (LD, 18-1-2000); zie ook de landelijk voorzitter van de FNV, Stekelenburg, in LD, 13-6-1996.

149 LD, 6-2-1991 en LD, 17-10-1991; DL, 16-12-1994; DL, 14-7-1995; LD, 13-9-1999. Zie ook de opzet van een informatiesysteem met gegevens over werken over grenzen in de EMR bij de arbeidsbureaus en de FNV-euroconsulent in LD, 28-1-1994; de publicatie van een handboek voor grensarbeiders van de euroconsulent van de FNV in DL en LD, 12-11-1997. 
werd geconcludeerd dat deze activiteiten een groot succes waren, en er binnen de EMR allerlei maatregelen werden genomen om het werken over grenzen te vergemakkelijken. Toch constateerden verschillende deskundigen dat de grensoverschrijdende arbeidsmobiliteit te beperkt was. Dit zou het gevolg zijn van het gebrek aan grensoverschrijdende arbeidsmarktinformatie, maar vooral van de problemen die de grensarbeiders ondervonden als gevolg van de voortdurende systeemverschillen. ${ }^{150}$

De beoordeling van de Duitslandpendel schoof vanaf het begin van de jaren 1990 dus verder in positieve richting. Vanuit regionaal oogpunt werd het niet meer alleen acceptabel, maar tevens wenselijk geacht dat er over de grens werd gewerkt. Grensoverschrijdende arbeidsmobiliteit zou zelfs onontbeerlijk zijn voor een gezonde ontwikkeling van de Zuid-Limburgse economie. De pendelproblematiek bestond er nu in dat de grenspendel zou worden afgeremd doordat hij te veel nadelen voor de grensarbeiders met zich mee zou brengen. Zuid-Limburg werd daarmee niet meer primair als deel van de nationale staat benaderd, maar als deel van een nieuwe territoriale eenheid, de EMR. Daarbij werd het streven naar een Euregionale arbeidsmarkt de nieuwe norm.

\section{Pioniers en slachtoffers}

In de jaren 1980 en 1990 werden de grensforensen dus positiever bejegend dan in de decennia daarvoor. Daarbij werd dikwijls verwezen naar hun rol in het Europese integratieproces. Inhakend op het streven naar een 'Europa zonder grenzen' betitelde de Euresconsulent van de FNV, grensarbeiders als 'pioniers van de interne markt'. ${ }^{151}$ De VEG refereerde eveneens veelvuldig aan Europa en noemde de grenspendelaars degenen die 'de Europese gedachte reeds jarenlang in de praktijk brengen'. ${ }^{52}$ De naam 'Vereniging Europese Grenslandbewoners' legt ook al een direct verband tussen grensgebieden, grensbewoners en Europa.

Keerzijde van de pioniersrol was dat het Europese integratieproces onvoldoende was gevorderd om probleemloos over grenzen te kunnen werken. De beeldvorming werd in deze periode gedomineerd door de gedachte dat de grensarbeiders zich in een 'financieel niemandsland' bevonden, doordat zij met allerhande discrepanties tussen de nationale stelsels van weten regelgeving werden geconfronteerd. ${ }^{153}$ Mede daardoor zou de grensoverschrijdende arbeidsmobiliteit beperkt blijven. Gezien haar streven naar een vrij verkeer van werknemers werd de verantwoordelijkheid voor de problemen voor een groot deel bij 'Europa' gelegd.

Europese instellingen zouden zich te weinig gelegen laten liggen aan het lot van de grensarbeiders. In het begin van de jaren 1980 verweet de voorzitter van de FNV in Limburg Europarlementariërs dat zij verstek lieten gaan bij een stemming over de resolutie van de Franse

150 Onderzoekers van het Researchcentrum Onderwijs en Arbeidsmarkt (ROA), Van Dam en De Grip, in LD, 20-11-1991; idem in DL, 26-11-1991; idem in 4-12-1997; ETIL in LD, 24-5-1994; economen van het ROA en ETIL in LD, 27-12-2001. Alleen de econoom De Neubourg stelde dat de grens geen rol speelde, omdat de lokale bevolking daar zou gaan werken waar ze de beste kansen kreeg (DL en LD, 1-12-1995). Desondanks stellen hij en zijn collega Van Haegendoren in hun rapport ook dat werkgevers pas grensarbeiders aannemen als 'het lokale aanbod' (binnen de grenzen) ontoereikend is en de grensbewoners vaak pas grensoverschrijdend gaan zoeken als er sprake is van hoge werkloosheid in de eigen woonomgeving binnen de grens. Bovendien spreekt hij naar aanleiding van een van de deelrapporten waarin werd geconstateerd dat de grensoverschrijdende pendelstromen naar Aken kleiner waren dan de binnenlandse, van een 'reëel effect van de grens' (De Neubourg en Van Haegendoren, Grensoverschrijdende pendel in de Euregio Maas-Rijn, 110, 115$116,126)$.

151 Dhr. Essers, DDL, 12-11-1997. In plaats van Eures-consulent werd ook de term 'euroconsulent' gebezigd.

152 Bijv. in LD, 22-9-1987; DL, 14-4-1994; DDL, 10-11-1998; secretaris van de VEG, Debets, in LD, 6-1-1986.

153 DDL, 2-2-2001. 
socialistische Europarlementariër Oehler. In deze resolutie stonden voorstellen om de positie van grensarbeiders te verbeteren. Wegens de absentie van de grotere partijen had volgens hem 'een handvol Engelse conservatieven de kans [...] de lijst-Euler [Oehler] met eisen ten behoeve van de grensgangers van de tafel te vegen'. ${ }^{154}$ Enkele jaren later liet de VEG zich kritisch uit over hetgeen 'Europa' tot dan toe had bereikt:

Als je ziet dat in Europese verordeningen gesproken wordt van 'gelijkheid van behandeling', 'niemand mag gediscrimineerd worden', 'slechts verzekerd volgens één stelsel', en nog meer kreten, is het dan niet terecht dat grensarbeiders zich afvragen of deze verordeningen niet in de prullenbak thuis horen en waarom het Europese parlement hier niets aan doet. ${ }^{155}$

In de jaren 1990 werd veelvuldig verwezen naar de totstandkoming van 'Europa '92', oftewel naar de Europese eenheidsmarkt. De secretaris van het Overleg Nederlandse Grensregio's, Geffen, verklaarde bijvoorbeeld:

Het televisiespotje van Postbus 51 suggereert dat na 1992 in Europa veel verandert voor de gewone burger. Het lijkt wel of dan alle problemen rond wonen en werken in een buurland verdwijnen. Maar niets is minder waar. ${ }^{156}$

'Europa' zou te zeer een top-downproject zijn en uitsluitend inspelen op de behoeften van het bedrijfsleven. De belangen van de bevolking, en met name die van de grensgebieden, zouden op de tweede plaats komen. Vakbonden en (meestal uit Limburg afkomstige) nationale politici waren een vergelijkbare mening toegedaan. Terwijl deze partijen in de jaren 1960 en 1970 zelden een goed woord over hadden voor de grenspendel, verweten zij 'Europa' nu een gebrek aan daadkracht om het grensoverschrijdend werken in grensgebieden zoals de EMR te vergemakkelijken. ${ }^{157}$

Desalniettemin hebben Europese autoriteiten diverse maatregelen genomen om problemen rond de grensoverschrijdende arbeidsmobiliteit weg te nemen. ${ }^{158}$ Deze konden in de Limburgse pers echter niet altijd op steun rekenen. Zo werd Verordening 1408/71 die de betaling van sociale zekerheidspremies van grensarbeiders regelt, 'pingpongbeleid' genoemd. ${ }^{159}$ Harmonisering van sociale en fiscale wetgeving gold nog steeds als de meest probate oplossing voor 'het pendelprobleem'. In tegenstelling tot de jaren 1960 en 1970 was de gedachte nu dat dit de pendelstroom zou faciliteren en stimuleren in plaats van hem af te remmen. Opnieuw werd erop geattendeerd dat deze harmonisering nog lang op zich zou laten wachten. ${ }^{160}$ De verantwoordelijkheid daarvoor werd merendeels bij nationale overheden gelegd.

154 LD, 3-3-1982.

155 Bestuurslid Debets in DL 5-3-1987.

156 Idem, 31-10-1991.

157 Zie dhr. Booij van het Christelijk Nationaal Vakverbond (CNV) in Heerlen tijdens een toespraak op een bijeenkomst van de IVR, in LD, 14-10-1991; het eerder aangehaalde PvdA-kamerlid Quint in LD, 16-11-1991; de Nederlands-Duitse Euregio's spraken ook wel van 'een vergeten hoofdstuk in de Europese eenwording' in DDL, 19-6-1997.

158 Voor een overzicht: zie hoofdstuk 1.

159 Een in Nederland woonachtige Duitse advocaat in LD, 13-6-1992.

160 Zie bijvoorbeeld voorzitter van de VEG, Debets, in LD, 22-9-1987; CDA-Kamerlid Oomen in LD, 14-4-1988 en als europarlementariër in LD, 2-6-1994; projectleider Eurequa (een project gericht op grensoverschrijdende samenwerking in het beroepsonderwijs), Hagenaars, in LD, 24-5-1994. 


\section{Tussen euroretoriek en nationaal belang}

Naast Europese autoriteiten werden ook nu met name nationale regeringen aangesproken op 'het pendelprobleem' ${ }^{161}$ Bij het uitvaardigen van nieuwe wet- en regelgeving zouden zij onvoldoende rekening houden met de belangen van de grensarbeiders en de grensgebieden. De Europese gedachte zou daarin nog onvoldoende zijn terug te vinden. Een woordvoerder van de VEG verwoordde het als volgt:

Het ene Europa? Vergeet het. Als grensgangers worden wij gediscrimineerd. Elk land kookt zijn eigen soep en wij mogen die twee keer oplepelen. ${ }^{162}$

Nationale overheden zouden 'hun eigen kas spekken over de ruggen van de grensarbeiders' door hen en/of hun gezinsleden onterecht te korten op uitkeringen of meer premies te laten betalen. ${ }^{163}$ De voorzitter van de VEG zag 'nationalistisch denken' als de grootste bedreiging voor de Europese eenwording. ${ }^{164}$ Economen die in het begin van de jaren 1990 constateerden dat er geen sprake was van een grensoverschrijdende arbeidsmarkt, stelden dat 'nationale belangentegenstellingen' maatregelen op Europees niveau in de weg stonden. ${ }^{165}$ De Euresconsulent van de FNV sprak in dit verband van een 'IJzeren Gordijn':

Ergerlijk is dat problemen van de grensbewoners/grensarbeiders veroorzaakt worden door nationale overheden, terwijl de politici voor de oplossingen steeds naar Brussel wijzen. Het zou de nationale overheden sieren als zij rekening zouden houden met de grensbewoners bij wijzigingen in het sociale en fiscale stelsel. Door dit niet te doen bouwt men boven de open economische binnengrenzen een steeds hogere barricade, een nieuw IJzeren Gordijn. ${ }^{166}$

Hij noemde het vrij verkeer van werknemers later 'een utopie' ${ }^{{ }^{167}}$ en weet het uitblijven van een gemeenschappelijke arbeidsmarkt niet aan 'drempelvrees' van grensbewoners, maar aan de afwijkende sociale en fiscale wetgeving. ${ }^{168}$ Door de onwil van nationale overheden om maatregelen te nemen, bleven de grensarbeiders volgens de Euresconsulent 'stiefkinderen van Europa' ${ }^{169}$

Ondanks de voortschrijdende Europese integratie constateerden de VEG en een vertegenwoordiger van de Nederlands-Duitse Euregio's aan het einde van de jaren 1990 dat de positie

\footnotetext{
161 Hoewel de voorzitter van de FNV afdeling Limburg in het begin van de jaren 1980 nog aangaf teleurgesteld te zijn in de Gedeputeerde Staten van Limburg die 'de grensgangersproblematiek naar Den Haag hebben afgeschoven' (LD, 3-3-1982), bestond er over het algemeen consensus over de verantwoordelijkheid van de nationale overheden voor 'de pendelproblematiek'.

162 VEG-lid Vellinga in DL, 14-4-1994. Zie ook: idem in DDL, 30-5-1998; idem in DDL, 10-11-1998.

163 Bijvoorbeeld de Witwenrente, secretaris van de VEG, Debets, in DL, 5-3-1987.

164 Voorzitter van de VEG, Debets, bij de overhandiging van een door de VEG opgestelde nota over de financiële problemen waar mee de Nederlandse Duitslandgangers kampten aan de Nederlandse en de Duitse staatssecretaris van Buitenlandse Zaken, resp. Van der Linden en Stavenhagen, in LD, 22-9-1987. Overigens wijst de Europese Commissie er in de Mededeling van de Commissie inzake de levens- en arbeidsvoorwaarden (32-34), op dat een voorstel voor een richtlijn om het pendelen te versoepelen in 1979 werd geblokkeerd door de Raad van Ministers. Zij kondigde inbreukprocedures aan tegen staten die niet-nationale werknemers discrimineerden (bijv. door hen geen recht op belastingaftrek toe te kennen).

165 Van Dam en De Grip in LD, 20-11-1991 en DL, 26-11-1994.

166 Dhr. Essers, DL, 7-3-1996.

167 DDL, 12-11-1997.

168 Dit in tegenstelling tot een medewerker van het arbeidsbureau in Aken die in het midden van de jaren 1990 stelde dat de belemmering vooral in de hoofden van mensen zat (DL, 14-7-1995).

169 LD, 19-6-1997; LD, 12-11-1997; zie ook de Sociaal Economische Advies Raad (SEAR) Limburg (een in 1987 opgericht en in 2002 opgeheven orgaan bestaande uit vertegenwoordigers van de sociale partners en het provinciebestuur, dat de RRA opvolgde en de provincie adviseerde over het te voeren sociaal-economisch beleid (zie http://www.ser.nl/publicaties/default.asp?desc =publicaties_bulletins_0200_4 (28-4-2007); http://www.ser.nl/ffi/media/Files/Internet/Publicaties/Overige/2000_2010/2003/ b22433_1.ashx (15-3-2008)); LD, 9-6-1994.
} 
van de grensarbeiders er, vooral op sociaal gebied, alleen maar op achteruit was gegaan. ${ }^{170} \mathrm{Het}$ werd voor hen steeds moeilijker om hun rechten en plichten te kennen. In het begin van de jaren 1980 werd ten aanzien van de dubbele premiebetaling van de ex-grensarbeiders al geconcludeerd dat het 'uiterst ondoorzichtige materie' betrof. ${ }^{171}$ Met de hervorming van de welvaartsstaten werden de bijbehorende arrangementen er niet eenvoudiger op. In de jaren 1980 en 1990 werd er daarom geregeld gehamerd op het belang van een goede informatievoorziening om de positie van de grensarbeiders te verbeteren. In de jaren 1990 werd dit bovendien als een middel gezien om de grensoverschrijdende arbeidsmobiliteit te bevorderen. ${ }^{172} \mathrm{De}$ kranten berichtten over diverse organisaties die initiatieven namen om grensarbeiders in te lichten over hun juridische positie. ${ }^{173}$ Zo makte een journalist melding van het Euregionaal klachtenbureau in Aken, dat in het midden van de jaren 1980 was opgericht en grensarbeiders trachtte voor te lichten over en helpen bij moeilijkheden. ${ }^{174}$ In 1990 kon 'het bureau [...] de regen van klachten al niet meer aan'. ${ }^{175}$ Aan het einde van de jaren 1990 betoogde de Euresconsulent van de FNV dat de grensarbeiders door de bomen het bos niet meer zagen en zelfs de betrokken instanties in het duister tastten over de relevante wet- en regelgeving, waardoor zij de grensarbeiders 'van het kastje naar de muur' stuurden. ${ }^{176} \mathrm{Om}$ de positie van de grensarbeiders te verbeteren stelde de IVR, naast een verbetering van de informatievoorziening, een zogenaamde 'Europatoets' voor, die lidstaten zou verplichten om de effecten van nieuwe wet- en regelgeving voor bijvoorbeeld grensarbeiders te onderzoeken. ${ }^{177}$

Een enkele keer werd uitsluitend de Duitse overheid ervan beticht de belangen van de grensarbeiders te negeren. In 1986 introduceerde de Duitse regering Kohl een nieuwe belastingwet die voor de Duitse ingezetenen een besparing opleverde, terwijl de in Nederland woonachtige grensarbeiders erdoor werden gedupeerd. De VEG merkte op dat hierdoor 'de klok weer enkele jaren terug wordt gedraaid, ook al ging bondskanselier Kohl volgens haar [de VEG] prat op de vooruitgang die de laatste maanden op Europees gebied is geboekt'. ${ }^{178} \mathrm{De}$ Europese retoriek van de Duitse regering zou haaks staan op de wijze waarop zij met de grensarbeiders omsprong. Verder hield de verantwoordelijke voor een project gericht op grensoverschrijdende samenwerking in het beroepsonderwijs, de Duitse overheid primair aansprakelijk voor 'de pendelproblematiek'. In 1994 zei hij: 'In het kleine Nederland is het politieke draagvlak hiervoor veel groter dan in het logge Duitsland, dat nog niet overtuigd is van de noodzakelijkheid van samenwerking. ${ }^{179}$

Meestal spraken (vaak uit Limburg afkomstige) politici, (vertegenwoordigers van de) grensarbeiders en vakbonden de Nederlandse regering aan op de 'misstanden'. ${ }^{180}$ Terwijl zij

170 DDL, 10-11-1998.

171 Verschillende bezoekers aan een door de FNV Limburg georganiseerde bijeenkomst over de premiebetaling van de ex-pendelaars FNV Limburg, in LD, 3-3-1982.

172 Bijvoorbeeld door het CDA in LD, 6-11-1981; onderzoekers van het Researchcentrum voor Onderwijs en Arbeidsmarkt (ROA) van de Universiteit Maastricht, Van Dam en De Grip, in LD, 20-11-1991 en DL, 26-11-1992; CDA-europarlementariër, Oomen, in LD, 26-1994.

173 Bijv. de commissie (ex-)grensarbeiders van het CDA (LD, 29-10-1981).

174 DL, 1-11-1991.

175 Medewerker van het klachtenbureau, Boldersdorf, in LD, 29-5-1990; LD, 11-9-1990.

176 DDL, 12-11-1997.

177 De IVR riep de premier van Nederland en oud-FNV-voorzitter, Kok, op zich hier als EU-voorzitter voor in te zetten (DDL, 19-2-1997).

178 Secretaris van de VEG, Debets, in LD, 7-1-1986; de Nederlandse Staatssecretaris Nootenboom van Financiën wees met betrekking tot de fiscale problemen ook naar de Duitse autoriteiten (LD, 1-8-1978). Het betrof de Duitse Steuersenkungsgesetz (zie ook LD, 6-11986).

179 Projectleider Eurequa, Hagenaars, in LD, 24-5-1994.

180 Voorzitter van de VEG, Debets, in LD, 22-9-1987. 
reeds in 1979 had aangegeven een baan over de grens als 'passend werk' te beschouwen, zou zij in de jaren 1990 nog 'niet hard aan een oplossing van de problemen van de grensarbeiders' werken en 'lijdzaam afwachten' ${ }^{181}$ CDA-Europarlementariër Oomen betoogde in 1994 dat 'vooral Nederland de remmende factor is als het gaat om het treffen van [Europese] maatregelen' op fiscaal gebied. ${ }^{182}$ De Nederlandse regering stelde in 1985 nog dat er geen sprake was van 'echte sociale nood', maar erkende drie jaar later de moeilijkheden waarvoor de (ex-) grensarbeiders zich gesteld zagen. ${ }^{1{ }^{8} 3}$ Niettemin betoogde staatssecretaris Hoogervorst van Financiën rond de eeuwwisseling dat de stelsels van sociale zekerheid 'grosso modo gelijkwaardig' waren en dat de verschillen 'de ene keer in het voordeel en de andere keer in het nadeel' van de grensarbeiders uitvielen. ${ }^{184}$ Voorts wees hij erop dat 'de grensarbeiders nooit verplicht [waren] om in Duitsland of België te gaan werken' ${ }^{185}$ Dat laatste leidde in 2001 tot een furieuze reactie van het uit Limburg afkomstige CDA-Kamerlid Stroeken en een voormalige grensarbeider, die benadrukten dat de Zuid-Limburgers ten tijde van de mijnsluitingen weinig keus hadden. ${ }^{186}$ Ongeacht haar dikwijls wat relativerende toon zou de Nederlandse overheid door de jaren heen verschillende maatregelen nemen om de positie van de grensarbeiders te verbeteren, zoals de opening van een fiscaal Steunpunt Grensstreek in 2000 en het afschaffen van een korting op de AOW van echtgenotes/n van grensarbeid(st)ers, het zogenaamde AOW-gat, in 2001. ${ }^{187}$ Vaak werden de regeringsmaatregelen evenwel afgedaan als 'lapmiddeltjes, die structureel niks verander[d]en'. ${ }^{188}$

De passieve houding van de Nederlandse overheid werd aan twee zaken toegeschreven. Op de eerste plaats zou zij samenhangen met het geringe aantal grensarbeiders. ${ }^{189}$ Ten tweede zou het gebrek aan inzet een gevolg zijn van de perifere ligging van Zuid-Limburg in Nederland:

Den Haag ligt in het westen en niet aan de grens. Dat is het probleem. Anders was deze problematiek al lang opgelost merkt Sjoerd Vellinga [lid VEG en medewerker Lufthansa] op. 'Toen ik er een ambtenaar op het departement van sociale zaken op aansprak, zei hij: 'mijnheer, dit probleem kennen wij hier niet. ${ }^{190}$

De voorzitter van het Overleg Nederlandse Grensregio's zag dit als een algemeen probleem van grensgebieden. Volgens hem werden 'de problemen van de grensregio [waaronder de knelpunten rond grensarbeid] [...] in Den Haag niet als nationale problemen erkend' ${ }^{191}$ Hier viel men terug op het vertoog van Zuid-Limburg als perifere regio in Nederland, waar de nationale overheid te weinig oog voor had. Volgens het PvdA-Kamerlid Quint had 'Den Haag

\footnotetext{
181 Staatssecretaris De Graaf van Sociale Zaken in De Limburger, 27-4-1979; Debets en Vellinga van de VEG in DDL, 10-11-1998.

182 LD, 9-11-1994.

183 Resp. staatssecretaris Koning van Financiën in DL, 7-3-1985 en staatssecretaris De Graaf van Sociale Zaken die in 1988 toezei 'de laatste oneffenheden (met betrekking tot de AOW- en AWBZ-premies die onder andere afgekeurde grensarbeiders moesten betalen, $\mathrm{SB})$ te zullen wegwerken' in LD, 14-4-1988.

184 DDL, 22-9-1999.

185 LD, 2-2-2001.

186 Respectievelijk LD, 2-2-2001; ingezonden brief in LD, 14-2-2001.

187 Over het Steunpunt Grensstreek, zie DDL, 10-2-2000; LD, 15-2-200o; over het beëindigen van de korting zie DDL, 11-12-2001. Verder stelde de regering de 'Commissie grensarbeiders' in die de regering moest adviseren over institutionele knelpunten waarmee de grensarbeiders werden geconfronteerd (zie verwijzing daarnaar in DDL, 24-4-2001; Commissie grensarbeiders, Rapport van de Commissie grensarbeiders).

188 Reactie van FNV-er, Schipper, namens de IVR op een nota van Minister De Graaf van Sociale Zaken over de fiscale en sociale positie van de grensarbeiders, LD, 24-5-1985.

189 Door de SEAR in LD, 9-6-1994 en journalist in LD, 27-9-1995.

190 DL, 14-4-1994.

191 Dhr. De Vries in DL, 31-10-1991.
} 
geen benul' van de problemen die grensarbeid met zich meebracht. ${ }^{192}$ De Euregionale visie op Zuid-Limburg als centrale regio in Europa verhinderde dus niet dat het binnen de nationale context nog steeds als achtergestelde periferie met een grote afstand tot het machtscentrum werd neergezet. Dit gevoel van achterstelling lijkt een constante in de Limburgse identiteit. ${ }^{193}$ Een belangrijk verschil met de jaren 1960 en 1970 was echter dat in die periode de grens nodig werd geacht om de regionale economische ontwikkeling te waarborgen, terwijl zij nu juist als belemmering daarvoor werd gezien.

\section{SLOT}

In het begin van de jaren 1970 publiceerde het Limburgs Dagblad een serie redactionele commentaren onder de noemer Visie op Limburg waarin onder andere kritische noten werden gekraakt over de arbeidsmobiliteit naar Duitsland. ${ }^{194}$ Ongeveer twintig jaar later verscheen in dezelfde krant een reeks onder de noemer Over de grenzen waarin op positieve wijze verslag werd gedaan van grensoverschrijdende activiteiten, die onder meer gericht waren op het faciliteren en stimuleren van de grenspendel. ${ }^{195}$ Dit verschil was tekenend voor de veranderende referentiekaders met betrekking tot (Zuid-)Limburg als grensgebied, waarbinnen de grenspendel door de jaren heen betekenis kreeg.

Gedurende de gehele periode vanaf het einde van de jaren 1950 tot en met 2001 kende de berichtgeving over de grenspendel veelal een normatieve lading. Hoewel er steeds werd gesproken van 'het pendelprobleem', betekende dit niet dat de pendel zelf steeds negatief werd beoordeeld. Daarnaast kreeg 'het pendelprobleem' een meervoudige betekenis. In de ontwikkeling van de beeldvorming rond de Duitslandpendel en de bijbehorende probleemdefinities kunnen twee perioden worden onderscheiden. Tot het einde van de jaren 1970 werd de grenspendel overwegend afgekeurd. In de daaropvolgende jaren werd hij geaccepteerd en met ingang van de jaren 1990 tevens verwelkomd. De (on)wenselijkheid van de grenspendel contrasteerde scherp met de werkelijke omvang van de pendelstroom. In de periode waarin de Duitslandpendel werd afgewezen, werd er op grote schaal in Duitsland gewerkt, terwijl er amper werd gependeld toen het werd geaccepteerd en toegejuicht. Mede in deze spanning zat het pendelprobleem.

In de eerste periode, vanaf het einde van de jaren 1950 tot het einde van de jaren 1970 wezen vooral Nederlandse sociale partners, Limburgse autoriteiten, journalisten en uit Limburg afkomstige politici, het werken over de grens af. Het pendelprobleem was in deze periode drieledig. Het bestond erin dat de omvangrijke grenspendel negatieve consequenties zou hebben voor de nationale economie, voor de persoonlijke situatie van de grensarbeiders en met name voor de regionale arbeidsmarkt. Harmonisering van sociale en fiscale wet- en regelgeving gold als de remedie. De verwachting was dat het minder aantrekkelijk zou worden om over de grens te werken als de institutionele verschillen werden gladgestreken. Op die manier zou het mogelijk zijn de bevolking van (Zuid-)Limburg in Nederland te houden. Aangezien men dit op korte termijn niet haalbaar achtte, werd er vooral een beroep gedaan op de nationale over- 
heid om het regionaal stimuleringsbeleid te intensiveren opdat Zuid-Limburg binnen de grenzen voldoende aantrekkelijke werkgelegenheid zou kunnen bieden aan de regionale beroepsbevolking.

In de tweede helft van de jaren 1970 vond er een herwaardering van de grenspendel plaats. Hij werd steeds positiever beoordeeld en 'Europese' ideeën konden steeds beter wortel schieten. Zo kreeg 'het pendelprobleem' met name onder (veelal uit Limburg afkomstige) politici, vakbonden en (vertegenwoordigers van) grensarbeiders zelf nu de betekenis dat de pendelaars ten onrechte nadelen ondervonden van hun complexe juridische positie. De gedachte was dat werken over de grens in principe gelijk diende te staan aan werken in eigen land. Daarmee werd de grenspendel impliciet geaccepteerd. Met ingang van de jaren 1990 gingen Euregionale en Limburgse autoriteiten, (veelal uit Limburg afkomstige) politici en vakbonden, het werken in Duitsland tevens verwelkomen. Toch werd er nog steeds gesproken van een 'pendelprobleem'. 'De pendelproblematiek' bestond er nu ook in dat het grenswerk zou worden belemmerd door alle nadelen die de pendel met zich meebracht. Opnieuw werden zowel Europese als nationale overheden aangesproken op hun verantwoordelijkheid voor 'het pendelprobleem'. De oplossing werd nog altijd gezocht in een harmonisering van sociale en fiscale wet- en regelgeving. Ditmaal moesten de institutionele discrepanties echter niet worden verminderd om de (Zuid-)Limburgers binnen te houden, maar juist om ze de grens over te krijgen. De grens mocht niet langer als obstakel naar buiten toe fungeren. Hoewel 'Europa' wel werd gewezen op de problemen en de wijze waarop deze zich tot haar doelstellingen verhielden, werden nog steeds nationale regeringen als hoofdverantwoordelijk gezien voor de beperkte convergentie tussen hun systemen van sociale en fiscale wet- en regelgeving.

$\mathrm{Nu}$ kan gesteld worden dat de grenspendel een grotere bedreiging vormt wanneer hij grotere vormen aanneemt en daarom tot in de tweede helft van de jaren 1970 werd afgekeurd. Maar indien we de grens wegdenken en ons realiseren dat de situatie op de Zuid-Limburgse arbeidsmarkt toen hoe dan ook weinig rooskleurig was, en het merendeel van de Zuid-Limburgse grensarbeiders op vrij korte afstand van hun woonplaats werkte, rijst de vraag waarom dit zo problematisch werd bevonden. De herdefiniëring van 'de pendelproblematiek' kwam dan ook niet zozeer voort uit de inkrimping van de pendelstromen, als uit een veranderende conceptie van (Zuid-)Limburg als grensgebied.

Terwijl de politiek-materiële dimensie van de grens centraal stond in de berichtgeving, ging het eigenlijk steeds om de vraag waar (Zuid-)Limburg bij hoorde en dus ook om de sociaal-culturele dimensie van de grens. In de eerste periode werd (Zuid-)Limburg als weliswaar perifeer, maar integraal deel van de Nederlandse staat gezien, dat zich onafhankelijk van het omringende buitenland diende te ontwikkelen. De regionale belangen werden in deze periode binnen een national kader gedefinieerd. Omdat grensarbeid hiermee op gespannen voet stond, werd het afgekeurd. In de tweede helft van de jaren 1970 maakte het nationaal begrensde referentiekader plaats voor een 'ontgrenzend' betekeniskader. De verwevenheid met buurlanden die met grenspendel gepaard ging werd vanaf het einde van de jaren 1970 geaccepteerd en met ingang van de jaren 1990 tevens toegejuicht. Vanaf de jaren 1990 werd ZuidLimburg primair als deel van de EMR als centrale Europese regio benaderd. Vanuit dit betekeniskader werd het openen van de grenzen voor arbeidsmobiliteit wenselijk bevonden. De belangen van Zuid-Limburg zouden niet meer zozeer gediend zijn bij eenzijdige integratie in de Nederlandse staat. Integendeel, de nationale grens werd meer en meer als knellend ervaren. 


\section{Hoofdstuk 6 \\ Grenzen verleggen Grensarbeiders over het werken in Duitsland}

Na ruim tien jaar in de Nederlandse zorg te hebben gewerkt, was Marion Leenders in de jaren 1990 gedurende vier jaar als hoofdverpleegkundige werkzaam in twee Duitse verzorgingstehuizen. ${ }^{1}$ Dat heeft er volgens haar toe geleid dat haar grenzen zijn 'verlegd' en haar 'blikveld is verruimd'. Ze heeft de grens in fysiek en sociaal-economisch opzicht overschreden, 'in keukens gekeken waar je (...) nooit in kan kijken', sociale contacten opgebouwd in Duitsland en haar beeld van de Nederlanders en de Duitsers bijgesteld. Toch betekent dit niet dat de Nederlands-Duitse grens geen rol van betekenis meer voor haar speelde. Nederland en Duitsland zijn voor haar twee deels gescheiden werelden gebleven. Zo werd Marion Leenders als gevolg van een aantal lichamelijke beperkingen geconfronteerd met de sterk afwijkende Nederlandse en Duitse arbeidsongeschiktheidsnormen. Hierdoor ging de grens als institutionele scheidslijn als een rode draad door haar leven lopen. Bovendien reproduceerde zij de grens, zij het impliciet, in haar eigen relaas. Zij typeerde de Duitse (private) ouderenzorg bijvoorbeeld als 'achterlopend' op de Nederlandse en kon zich niet verplaatsen in 'het beperkte sociale invoelingsvermogen' van Duitsers in hogere posities. Terwijl ze de verschillen met de werksituatie en collega's in Nederland ook aan andere zaken kon toeschrijven, weet zij deze direct aan de andere nationale context. Ofschoon ze aangaf dat de grens door haar werkervaring in Duitsland deels was uitgewist, bleef deze dus nog wel degelijk als scheidslijn in haar dagelijks leven en betekenisgeving aanwezig.

In dit hoofdstuk worden op basis van 26 interviews met (ex-)grensarbeid(st)ers hun ervaringen met het werken in Duitsland in kaart gebracht. ${ }^{2} \mathrm{Zij}$ worden als het ware gevolgd in hun traject op weg naar, in en uit Duitsland. Dat gebeurt in vijf stappen, van de totstandkoming van de grenspendel, de reis naar het werk, de eerste ervaringen op de werkvloer, tot de inburgering in Duitsland en vervreemding van Nederland, en, indien van toepassing, het beëindigen van de arbeidsrelatie met Duitsland en de periode daarna. Daaruit zal blijken hoe enerzijds de ervaringen met het werken in Duitsland en anderzijds de betekenis van de grens, zowel in haar politiek-materiële als haar sociaal-culturele dimensie, elkaar onderling vormgaven.

\section{OVER EEN DREMPEL}

Het traject dat de grensarbeiders aflegden, begon met de beslissing om in Duitsland te gaan werken. De geïnterviewde pendelaars noemden daarvoor twee hoofdmotieven: de betere verdiensten aan Duitse en een gebrek aan werk aan Nederlandse zijde van de grens. Beide han-

1 Om de privacy van de informanten te waarborgen wordt gebruik gemaakt van pseudoniemen.

2 Voor meer over deze methode: zie hoofdstuk 2; voor meer informatie over de uitvoering van dit deel van het onderzoek en de informanten: zie appendix C. In verband met de leesbaarheid wordt hier steeds gesproken van 'grensarbeiders'. 
gen samen met de afwijkende arbeidsmarktsituatie aan weerszijden van de grens en gingen dikwijls hand in hand. Zij reageerden dus op de eerder beschreven paradox van de grens. Vooral degenen die in de jaren 1960 en 1970 in Duitsland gingen werken, verwezen veelvuldig naar de hoge Duitse lonen als belangrijke drijfveer. Diverse grensarbeiders zeiden nog exact te kunnen vertellen hoe hoog hun eerste Duitse loon was. ${ }^{3}$ Met name jongere pendelaars konden in die tijd relatief veel verdienen, omdat zij in Duitsland al volwassenenloon ontvingen. ${ }^{4}$ Ook toen de arbeidsmarktsituaties aan weerszijden van de grens in de jaren 1980 en 1990 meer gelijkenis vertoonden, bleef er een beloningsverschil bestaan dat voor diverse grensarbeiders reden was om in Duitsland te gaan werken. De resultaten van enquêtes die in de jaren 1970, 1980 en 1990 onder grensarbeiders werden afgenomen, bevestigen het belang van de loonverschillen. ${ }^{5}$ Toch moeten deze enigszins worden gerelativeerd. Ondanks de goede verdiensten in Duitsland gaven verschillende grensarbeiders te kennen zowel in de jaren 1960 en 1970 als in de jaren 1980 en 1990 bijbanen in Nederland te hebben gehad als bijvoorbeeld kelner of stratenmaker om hun Duitse inkomsten aan te vullen. Blijkbaar werd het Duitse loon niet altijd als toereikend ervaren. ${ }^{6}$

De andere reden om de koers naar Duitsland te verleggen, was volgens de grensarbeiders het ontbreken van (passend) werk aan Nederlandse zijde van de grens. Dat gold voor de gehele periode vanaf het einde van de jaren 1950 tot en met 2001. Het belang van het gebrek aan (zeker) werk wordt door eerdere enquêtes bevestigd. ${ }^{7}$ Voor de geïnterviewde grensarbeiders was werk in Duitsland in de jaren 1960 en 1970 een manier om aan het gebrek aan of de onzekerheid over werk in de directe Nederlandse woonomgeving te ontsnappen. Zo zag een aantal mannen dat in de jaren 1960 in opleiding was bij een mijnbedrijf daar geen toekomst meer door het zware ondergrondse werk en de ongewisse toekomst van die bedrijfstak in Nederland. Het Nederlands Economisch Instituut (NEI) stelde dat een baan in Duitsland ten tijde van de mijnsluitingen meer zekerheid bood dan de nog te creëren nieuwe werkgelegenheid aan Nederlandse zijde van de grens. ${ }^{8}$ Mannelijke kostwinners gaven verder aan dat de verantwoordelijkheid voor het gezinsinkomen een extra stimulans was om een baan in Duitsland te accepteren. Mede vanwege hun gezin waren deze grensgangers meestal ook niet bereid om binnen Nederland te verhuizen voor een baan. De Duitslandpendel kwam daarmee tevens voort uit een zekere streekgebondenheid. ${ }^{9}$ Door in Duitsland te gaan werken was het mogelijk in Zuid-Limburg te blijven wonen en zekerder en beter betaald werk te hebben. Hoewel we in

3 Uit de enquête van het Nederlands Economisch Instituut (NEI) uit 1972 bleek overigens dat vooral grensarbeiders in de bouw het loonverschil tussen Nederland en Duitsland te hoog inschatten: zij dachten dat het 45 procent bedroeg, terwijl het verschil volgens de officiële cijfers in 1971 slechts 33 procent bedroeg. Dit kan te maken hebben met de ruime mogelijkheden tot overwerk en de hoge prestatietoeslagen (Van den Berg et al. De grenspendel in Limburg, 51, 94; Hendriks et al., De gevolgen van de pendel op Duitsland, D4). Op basis van zijn minder representatieve enquêteresultaten wees Vreuls er in het begin van de jaren 1980 dan weer op dat een groot deel van zijn respondenten, die weliswaar aangaven vanwege het hoge Duitse loon in Duitsland te zijn gaan werken, geen idee had van het loonverschil met Nederland ('Grenzüberschreitende Pendlerwanderungen', 9).

4 In 1971 en 1972 bijvoorbeeld gold in de Duitse bouw vanaf het twintigste jaar het volwassenenloon en in de Nederlandse bouw vanaf het tweeëntwintigste. Bovendien konden bouwvakarbeiders in Duitsland reeds vanaf hun achttiende tariefarbeid verrichten, hetgeen in Nederland verboden was (in Nederland waren alleen prestatietoeslagen mogelijk) (zie Van den Berg et al. De grenspendel in Limburg, 53-58). 5 Van den Berg et al., De grenspendel in Limburg, 106-107; Hendriks et al. De gevolgen van de pendel op Duitsland, D8; Vreuls, 'Grenzüberschreitende Pendlerwanderungen', 9-10; Soutif, 'Domicile-travail', 132; Soutif, L'intégration européenne, 176-177, 183.

6 Ruim een derde van de 64 mannelijke respondenten van de geograaf Vreuls gaf in 1980 ook aan dat hun inkomen ongeveer gelijk aan of zelfs kleiner was dan dat van degenen die in Nederland werkten, als gevolg van bijvoorbeeld het mislopen van een studiebeurs voor de kinderen ('Grenzüberschreitende Pendlerwanderungen', 9). Later in dit hoofdstuk volgt meer over financiële consequenties van de systeemverschillen tussen Nederland en Duitsland waar de grensarbeiders mee werden geconfronteerd.

7 Zie ook Van den Berg et al., De grenspendel in Limburg, 106-107; Vreuls, 'Grenzüberschreitende Pendlerwanderungen', 9-10; Soutif, 'Domicile-travail', 132; Soutif, L'intégration européenne, 176.

8 Hendriks et al., De gevolgen van de pendel op Duitsland, 19, 28-29.

9 Zie ook Vreuls, 'Grenzüberschreitende Pendlerwanderungen', 7. 
hoofdstuk 4 hebben gezien dat de pendelstroom in deze periode een fluctuerend verloop kende, werden diverse geïnterviewde grensarbeiders die al vóór de recessie van 1966 en 1967 in Duitsland waren gaan werken, in deze periode niet ontslagen. Ook in de jaren daarna leek het werk in Duitsland de grensarbeiders meer garanties te bieden dan zij in Zuid-Limburg konden krijgen.

De grensarbeiders die in de jaren 1960 en 1970 bij gebrek aan werk naar Duitsland trokken, beschouwden zichzelf als verantwoordelijke burgers die niet op kosten van de Nederlandse gemeenschap wilden leven door een werkloosheidsuitkering aan te vragen. Dit komt overeen met het beeld dat een aantal grensarbeiders en anderen destijds in de regionale pers neerzetten tegenover het dominante beeld dat de grenspendel schadelijk zou zijn voor de nationale en regionale gemeenschap, hun gezin en zichzelf.

In de jaren 1980 en 1990 vormde het ontbreken van geschikt werk aan Nederlandse zijde van de grens nog steeds aanleiding om in Duitsland te gaan werken. In tegenstelling tot de jaren 1960 en 1970 ging het nu vaker om inhoudelijk passend werk en het betrof nu meer hoger opgeleiden. Zij konden in Zuid-Limburg wel werk vinden, maar niet in hun vakgebied. Zo rondde Françoise Pieterse in de tweede helft van de jaren 1980 haar logopedieopleiding af en ging zij vervolgens in Zuid-Limburg en andere delen van Nederland op zoek naar een baan als logopediste. Omdat het er 'toen gewoon heel slecht uitzag in Nederland' kwam ze er in haar eigen vakgebied niet tussen. Na een aantal jaren een andere baan in Zuid-Limburg te hebben gehad, deed zich in het begin van de jaren 1990 de gelegenheid voor om als logopediste in Duitsland te gaan werken. Die kans benutte zij graag.

Grensarbeiders waren dus in de hele periode vanaf het einde van de jaren 1950 tot en met 2001 bereid hun grenzen te verleggen om verzekerd te zijn van (passend) werk en een goed inkomen, en in veel gevallen tevens om in Zuid-Limburg te kunnen blijven wonen. Voordat zij echter de knoop konden doorhakken om in Duitsland te gaan werken, dienden ze zich eerst te realiseren dat dit een optie voor hen was. Zoals in hoofdstuk 4 is gebleken ging slechts een beperkt deel van de Zuid-Limburgse beroepsbevolking daartoe over, ondanks de voordelen die het werken in Duitsland met zich mee kon brengen. Velen lijken niet stil te hebben gestaan bij de mogelijkheid om in Duitsland te gaan werken.

De geografen Van der Velde en Van Houtum schrijven de hedendaagse immobiliteit van Europese grensbewoners toe aan een threshold of indifference, die grensbewoners ervan weerhoudt de mogelijkheid om over de grens te gaan werken op te merken. ${ }^{10}$ Ook onder de geïnterviewde pendelaars blijkt de Duitse arbeidsmarkt aanvankelijk een blinde vlek te zijn geweest. Zij overschreden de grens wel al, zij het in wisselende mate, om bijvoorbeeld te winkelen, recreëren of familie te bezoeken. Met name in de jaren 1960 en 1970, toen er nog maar enkele televisie- en radiozenders in de lucht waren, keken zij ook vaak Duitse televisie of luisterden zij naar Duits(talige) radiozenders. Onderzoek wijst uit dat dergelijke activiteiten de stap naar de Duitse arbeidsmarkt kunnen verkleinen. ${ }^{11}$ Dit betekende evenwel niet dat de grensarbeiders zelf op het idee kwamen om ook in Duitsland te gaan werken. Deze selectieve inertie is te verklaren uit de grotere rol die werk speelt in het dagelijks leven en het relatief intensieve

10 Van der Velde en Van Houtum, 'De-politicizing labour market indifference', 47-50; Van Houtum en Van der Velde, 'The power of labour market immobility', 102-105.

11 Van der Velde, 'Grensoverschrijdend zoekgedrag op de arbeidsmarkt', 103. 
contact met het buurland dat grensarbeid met zich meebrengt. Dat maakt de stap om over de grens te gaan werken vele malen groter dan om er bijvoorbeeld te gaan winkelen of recreëren.

Hoe kwam men er dan toch toe om in Duitsland te gaan werken? Gedurende de gehele periode vanaf het einde van de jaren 1950 tot en met 2001 was informatie afkomstig van personen uit informele sociale netwerken cruciaal om de drempel naar de Duitse arbeidsmarkt te verlagen. Familie, vrienden of bekenden die zelf in Duitsland werkten of anderen kenden die er werkten, hebben de geïnterviewde grensarbeiders op de mogelijkheden over de grens geattendeerd. De mannen die in de jaren 1960 in opleiding waren bij de mijnbedrijven, werden door oudere collega's gewezen op de slechte vooruitzichten in de Nederlandse mijnen en de kansen in Duitsland. Op basis van onderzoek in het grensgebied bij Nijmegen constateren Van der Velde et al. dat informatie afkomstig uit de vertrouwde sociale omgeving vooronderstellingen over (werken aan) de andere kant van de grens kan wegnemen, waardoor de persoon in kwestie zich daar meer voor open gaat stellen. ${ }^{12}$ Het feit dat familie of bekenden in Duitsland werkten, kon meer vertrouwen geven in een goede afloop. Zo werd Bep de Wever in het begin van de jaren 1960 door haar moeder en zus gevraagd hen te vergezellen naar een confectieatelier vlak over de grens. Zij werkte op dat moment nog bij een elektronicafabriek in Heerlen en vond de stap om in Duitsland te gaan werken erg groot. In dat opzicht ervoer zij het nog als 'echt buitenland'. Aversie tegenover Duitsers als gevolg van de Tweede Wereldoorlog speelde daarbij een rol. Het feit dat haar zus en moeder reeds in Duitsland werkten, maakte 'de drempel wat lager om binnen te komen'. Ook uit verschillende enquêtes onder Duitslandgangers blijkt dat informatie afkomstig van personen uit informele sociale netwerken belangrijk was om een brug naar Duitsland te slaan. ${ }^{13}$ Ten tijde van de krappe Duitse arbeidsmarkt in de jaren 1960 en 1970 kon er op deze manier een sneeuwbaleffect ontstaan. ${ }^{14}$ In de jaren 1960 en het begin van de jaren 1970 kon het voor grensarbeiders zeer lucratief zijn anderen over vacatures in Duitsland te informeren, omdat de grote arbeidstekorten Duitse werkgevers ertoe aanzetten premies uit te loven voor het aandragen van nieuwe werknemers. ${ }^{15} \mathrm{Om}$ de drempel verder te verlagen namen diverse Duitse werkgevers bovendien de formaliteiten die met de grenspendel gepaard gingen voor hun rekening. ${ }^{16}$

Officiële informatiekanalen blijken in de gehele onderzoeksperiode nauwelijks een rol te hebben gespeeld bij het overschrijden van de drempel naar Duitsland. Hoewel volgens Van der Velde et al. ook arbeids- en uitzendbureaus een verbinding met de arbeidsmarkt aan de overzijde van de grens tot stand kunnen brengen, ${ }^{17}$ zijn slechts enkele van de geïnterviewde grensarbeiders door een arbeids- of uitzendbureau ingelicht over werk in Duitsland. Een voorbeeld is Marion Leenders die in de jaren 1990 op eigen initiatief een Euresconsulent bij het arbeidsbureau in Aken benaderde. Zij had echter reeds besloten een baan in Duitsland te zoeken omdat zij en haar echtgenoot, die er reeds jarenlang werkte, er op termijn wilden gaan wonen. Resultaten van eerdere onderzoeken naar grenspendel uit (Zuid-)Limburg bevestigen

12 Zie Van der Velde et al., 'Job mobility in the Dutch-German regional labour market', 89-91.

13 Van den Berg et al. De grenspendel in Limburg, 89; Vreuls, 'Grenzüberschreitende Pendlerwanderungen', 7; zie ook Van Goethem en Doumen, Grensarbeid in de Euregio Maas-Rijn, 128-129: werkgevers noemen zowel informele netwerken van grensarbeiders alsmede van werkgevers als belangrijk wervingskanaal.

14 Zie ook DBA, Arbeidsmarktbeschrijuing 1964, 45-46.

15 Zie ook een artikel in De Limburger waarin werd gesproken over werfpremies van 300 tot 400 gulden (DL, 13-6-1973).

16 De grensarbeiders moesten bijvoorbeeld worden geregistreerd bij de Ortskrankenkasse in verband met hun ziektekostenverzekering en moesten tot 1970 een werkvergunning aanvragen.

17 Van der Velde et al. 'Job mobility in the Dutch-German regional labour market', 89-91. 
de marginale rol van arbeids- en uitzendbureaus in de eerste informatievoorziening over het werken in Duitsland. ${ }^{18}$

In de jaren 1960 en 1970 heeft een aantal geïnterviewde grensarbeiders wel via Nederlandse koppelbazen of onderaannemers in de Duitse bouw of industrie gewerkt. Deze tussenpersonen kunnen als voorgangers van de uitzendbureaus worden beschouwd. Volgens de grenspendelaars hielden zij meestal kantoor in Duitsland en stelden ze de grensarbeiders tijdelijk tewerk bij Duitse werkgevers. Van de respondenten die het NEI in het begin van de jaren 1970 enquêteerde, werkte ongeveer een kwart van de pendelende bouwvakkers en 7 procent van de pendelende fabrieksarbeiders via een dergelijke intermediair in Duitsland. ${ }^{19}$ Hoewel regionale kranten melding maakten van wervingsacties van koppelbazen en onderaannemers, ${ }^{20}$ was onder de geïnterviewde grenspendelaars ook in dit verband informatievoorziening via personen uit de directe sociale omgeving doorgaans doorslaggevend om op de gedachte te komen dat werken in Duitsland een optie was. Net als de Duitse werkgevers maakten intermediairs hiervan handig gebruik door premies uit te loven voor het aandragen van nieuwe arbeidskrachten. ${ }^{21}$

Geen van de geïnterviewde grensarbeiders is via vacatures in de Limburgse dagbladen met de Duitse arbeidsmarkt in aanraking gekomen. Toch zouden deze met name in de jaren 1960 en 1970 met enige regelmaat verschijnen. ${ }^{22}$ Wel is een aantal pendelaars via een Duitse krant over vacatures in Duitsland geïnformeerd. Dit gebeurde bij toeval of door de gerichte aankoop van zo'n krant nadat de belangstelling voor een baan in Duitsland reeds was gewekt door personen uit hun sociale netwerk. ${ }^{23}$

Gedurende de gehele onderzoeksperiode was informatie afkomstig van personen uit de naaste omgeving van de grensarbeiders dus essentieel om de threshold of indifference naar Duitsland te slechten. Ook nadat zij hadden besloten in Duitsland te gaan werken, hield deze nog gedeeltelijk stand. Aanvankelijk bleven de grensarbeiders terughoudend ten aanzien van de grenspendel. Bep de Wever die met haar moeder en zus in Duitsland ging werken, noemde het 'een sprong in het diepe', waarvan ze de consequenties niet helemaal kon overzien. Ze beschouwde zichzelf daarom als 'avonturier'. Anderen zeiden 'toch wel een risico' te hebben genomen, of dat ze wel zouden 'zien waar het schip strandde'. ${ }^{24}$ Dat de grensarbeiders enige reserves hielden, blijkt ook uit hun oorspronkelijke intentie om slechts tijdelijk in Duitsland te werken, bijvoorbeeld om ervaring op te doen of totdat ze in Zuid-Limburg werk zouden vinden.

18 Zie Vreuls, ‘Grenzüberschreitende Pendlerwanderungen', 7; Van Dam en De Grip, De Euregionale arbeidsmarkt, V; Van Goethem en Doumen constateerden in het midden van de jaren 1990 dat ook werkgevers in de EMR weinig gebruik maakten van arbeids- en uitzendbureaus om over de grens personeel te werven (Grensarbeid in de Euregio Maas-Rijn, 123-128). Ruim vijf jaar later merken Van Camp et al. echter op dat Nederlandse werkgevers juist wel vaak gebruik maken van uitzendbureaus om in Duitsland te werven (Naar de arbeidsmarkt zonder grenzen, 106).

19 In de dienstverlening kwam dit zelden voor (Van den Berg et al., De grenspendel in Limburg, 97). Het aandeel grensarbeiders dat via een tussenpersoon werkte kan groter zijn geweest dan uit de enquête naar voren kwam, omdat mogelijk niet iedereen dit prijsgaf vanwege de slechte reputatie van de onderaannemers en koppelbazen en het mogelijk informele karakter.

20 LD, 24-3-1961; DL, 5-7-1973.

21 Zie ook bijv. DL, 30-5-1973.

22 LD, 11-7-1973.

23 Vgl. het onderzoek van Van Goethem en Doumen (Grensarbeid in de Euregio Maas-Rijn, 121-123) waarin werkgevers uit de Euregio Maas-Rijn zeggen vooral personeel te zoeken via advertenties in dagbladen in eigen land.

24 Zie resp. Wim Ramakers en Wouter Slootman. Zie ook het voorbeeld in Van der Velde et al. 'Job mobility in the Dutch-German regional labour market', 89 . 
Grensarbeiders beschouwden het werken in Duitsland dus veelal als een experiment met een ongewisse uitkomst. Sommigen hielden zich aan hun voornemen om tijdelijk naar Duitsland te pendelen en probeerden tussentijds terug te keren naar de Nederlandse arbeidsmarkt. Dat bleek niet altijd eenvoudig. Nadat hij enige jaren als lasser en monteur in Duitsland had gewerkt, probeerde René Veldman in de jaren 1970 weer een baan in Nederland te vinden. Maar toen hij zich bij een arbeidsbureau wilde inschrijven, kreeg hij daar de reactie: 'Jongen, blijf in Duitsland, hier in Nederland is geen werk'. Terugkeren bleek gezien de ongunstige situatie op de Zuid-Limburgse arbeidsmarkt niet altijd een optie. ${ }^{25}$ Anderen beviel het werk goed genoeg om langere tijd te blijven pendelen. Veel grensarbeiders hebben gedurende meer dan tien jaar in Duitsland gewerkt. ${ }^{26}$

Dat betekent niet dat de grensarbeiders steeds bij dezelfde werkgever bleven. Vooral in de jaren 1960 en de eerste helft van de jaren 1970 was het verloop groot. ${ }^{27}$ Er was destijds volop werk in de bouw en de industrie, waardoor de grensarbeiders selectief konden zijn. Bouwvakarbeiders veranderden het vaakst van baan. Leo Hamers werkte in de jaren 1960 en 1970 in de Duitse woning- en wegenbouw en wisselde in die periode regelmatig van werkgever:

Er waren eigenlijk twee hoofdredenen om van werkgever te veranderen. Het ten einde lopen van het werk en geen zin hebben om met die firma mee te gaan naar een plaats verder weg. Dan moest je toch ver reizen. Of er kwam weer een of andere hotemetoot en die zei: 'Ik betaal jullie dit, als je bij mij komt werken'. Ja, dat was toch vaak genoeg zo aanlokkelijk dat je zei: 'Ja, asjemenou, maar daar gaan wij naartoe'. En meestal was dat dan ook nog wel een project dat langer zou doorlopen dan hetgeen waar je aan werkte.

Grensarbeiders wisselden normaal gesproken van baan wanneer zij het werk niet langer als 'passend' beschouwden, omdat de arbeidsomstandigheden slecht waren, er elders meer verdiend kon worden, of wanneer een nieuw bouwproject te ver van huis verwijderd was. Veel bouwvakkers werkten in die tijd met Nederlandse ploegjes bestaande uit ongeveer tien personen die gezamenlijk van project naar project trokken. Koppelbazen en onderaannemers speelden hier ten tijde van de krappe Duitse arbeidsmarkt op in door de grensarbeiders op de bouwplaatsen te benaderen en ander werk aan te bieden tegen betere voorwaarden. Tijdens de economische recessie(s) en in de jaren 1980 en 1990 was het moeilijker om van werkgever te veranderen en konden de grensarbeiders minder kieskeurig zijn.

Hoewel personen uit het sociale netwerk van de grensarbeiders een essentiële rol speelden bij de totstandkoming van de grenspendel, was niet iedereen uit hun sociale omgeving te spreken over het werken in Duitsland. Onder de grensarbeiders uit de NEI-enquête van 1972 was ongeveer in de helft van de gevallen de naaste omgeving overwegend positief. ${ }^{28}$ De geïnterviewde grensarbeiders zeggen dat het feit dat zij werk hadden en, met name in de jaren 1960 en het begin van de jaren 1970, veel verdienden, een instemmende reactie in de hand werkte. Maar de goede betaling kon eveneens afgunstige reacties oproepen. Zo zeggen verschillende

25 Vgl. de respondenten van Vreuls uit 1980, waarvan tweederde (vanwege belastingnadelen) tussentijds wilde stoppen met pendelen. Dit werd echter verhinderd door het gebrek aan werk in Zuid-Limburg ('Grenzüberschreitende Pendlerwanderungen', 10).

26 Zie ook de enquête van het NEI, waarbij de helft van de respondenten aangaf te zullen blijven pendelen bij gelijkblijvende loonverschillen. Tegelijkertijd zei bijna tweederde wel ermee te stoppen wanneer ze in Limburg even veel konden verdienen als in Duitsland (Van den Berg et al., De grenspendel in Limburg, 108-109, 118). Soutif wier 32 Nederlandse respondenten in het midden van de jaren 1990 gemiddeld ruim 20 jaar in Duitsland dan wel België werkten ('Domicile-travail', 134-135).

27 Zie ook Van den Berg et al., De grenspendel in Limburg, 86; Vreuls, 'Grenzüberschreitende Pendlerwanderungen', 7.

28 Hendriks et al., De gevolgen van de pendel op Duitsland, D19. 
geïnterviewde grenspendelaars erop te zijn gewezen dat zij daarvoor wel lange dagen moesten maken. Verder hadden ouders of grootouders door traumatische ervaringen in de Tweede Wereldoorlog soms hun bedenkingen en zagen anderen het werken in Duitsland zowel in de jaren 1960 en 1970 als de jaren 1980 en 1990, als avontuurlijk of zelfs 'roekeloos' ${ }^{29}$ Limburgse werkgevers reageerden in de jaren 1960 en 1970 soms furieus wanneer de grensarbeiders hun baan opzeiden in verband met werk in Duitsland. Zij wilden de pendelaars geen ontslag verlenen of voorspelden dat zij binnen de kortste keren 'met hangende pootjes terug' zouden keren. ${ }^{30}$ In tegenstelling tot de opiniemakers in de Limburgse pers stond dus lang niet iedereen afwijzend tegenover het werken in Duitsland. Indien de sociale omgeving van de grensarbeiders kanttekeningen plaatste, wees zij hoofdzakelijk op de persoonlijke consequenties die het werken in Duitsland zou kunnen hebben. De in de kranten prominent aanwezige verwijzingen naar de schadelijke gevolgen van de grenspendel voor de Nederlandse economie of de regionale arbeidsmarkt, bleven echter uit.

\section{ONDERWEG}

Zodra de grensarbeiders in Duitsland werkten, reisden zij voortdurend heen en weer tussen Nederland en Duitsland. In hoofdstuk 4 is gebleken dat de grensarbeiders in de jaren 1960 en 1970 niet alleen direct over de grens werkten, maar bijvoorbeeld ook in het Ruhrgebied. Wanneer de afstand tot het werk te groot was om dagelijks te overbruggen (doorgaans bij een reistijd vanaf ongeveer twee uur enkele reis), bleven zij van maandag tot en met vrijdag of zaterdag in Duitsland. Hun werkgever voorzag hen dan van huisvesting, bijvoorbeeld in barakken naast een bouwplaats of in een hotel. Ter compensatie van hun afwezigheid thuis ontvingen de weekpendelaars een toeslag op hun loon. De weekpendel was beroeps- en geslachtsgebonden. Het betrof hoofdzakelijk mannelijke bouwvakkers die door de week in Duitsland bleven. De bouwprojecten lagen soms ver van huis. Vrouwen werkten niet in de bouw en hun positie in het gezin maakte dat vrouwelijke grensarbeiders meestal dagelijks naar huis terugkeerden. Bij de mannen kon de gezinssituatie reden zijn om op den duur een punt achter de weekpendel te zetten. Zo stapte Jo Lemmens, die vanaf het einde van de jaren 1960 een aantal jaar als weekpendelaar in de Duitse bouw had gewerkt, na zijn huwelijk in 1972 over op dagpendel. Hij vreesde dat zijn afwezigheid door de week een te grote wissel zou trekken op zijn gezinsleven. Ook anderen zagen zich door een huwelijk of de geboorte van kinderen genoopt werk dichterbij huis te zoeken, waardoor het eerder beschreven verloop in de bouwsector werd versterkt.

De meeste grensarbeiders zijn nooit als weekpendelaar actief geweest, maar reisden dagelijks heen en weer. ${ }^{31}$ Hoe kreeg dit grensverkeer gestalte? Vanwege de ontbrekende of slechte verbindingen werd nauwelijks gebruik gemaakt van het openbaar vervoer. ${ }^{32}$ Sommige grenspendelaars woonden zo dichtbij hun werk dat zij dit per brommer of fiets konden bereiken.

\footnotetext{
29 Zie Jo Lemmens.

30 Zie Louis Franssen.

31 In 1961 werd het percentage Limburgse weekpendelaars op 20 tot 25 procent geschat (DNL, 4-3-1961; LD, 9-11-1961). Ruim tien jaar later bedroeg het aandeel weekpendelaars nog maar zo'n 4 tot 5 procent (Van den Berg et al., De grenspendel in Limburg, 92-93; zie ook LD, 2-1-1972).

32 Zie ook Van den Berg et al., De grenspendel in Limburg, 92-93. Overigens reisde Fred Wolters sinds 2005 met de zogenaamde Euregiobahn, de treinverbinding tussen onder meer Heerlen en Aken, naar zijn werk.
} 
Nederlandse grensarbeiders met hun auto voor een Duitse fabriek (begin jaren 1970). Bron: SHCL: DOC 62, II, nr. 46 (foto bij artikel in Televizier 1971$, nr. 6$)$

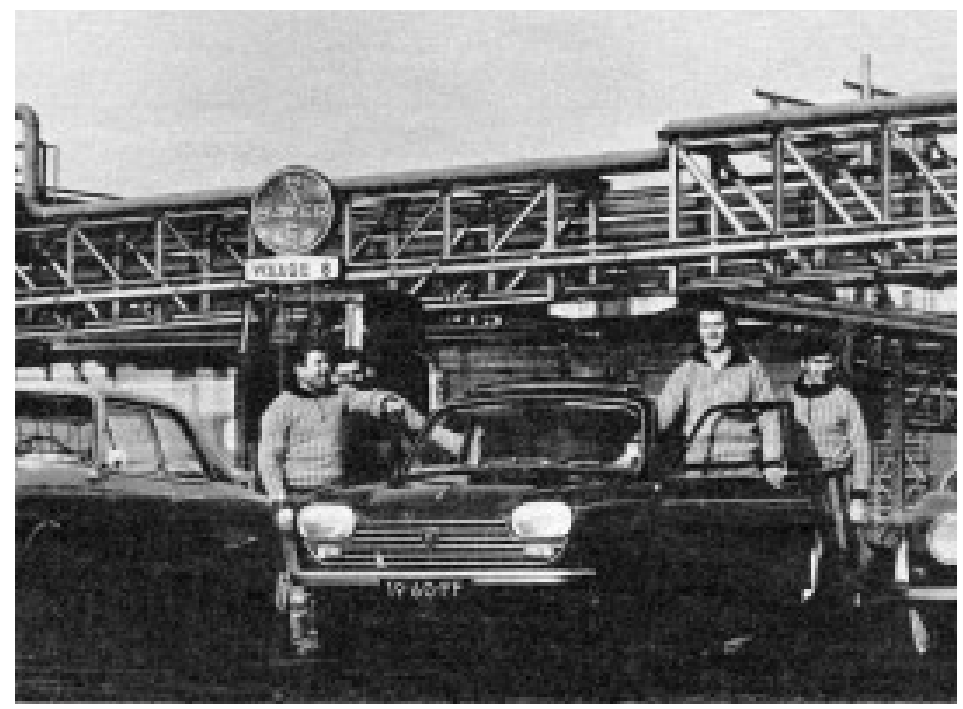

Anderen reisden, veelal in gezelschap van andere Nederlandse collega's, per touringcar, busje of auto naar Duitsland. In de jaren 1960 en het begin van de jaren 1970 zette de grootschalige inzet van personeel uit Zuid-Limburg Duitse werkgevers ertoe aan zelf vervoer te organiseren. Zij huurden grote touringcars of kleinere autobusjes in, dikwijls bij bedrijven in ZuidLimburg.

Niettemin was het gebruikelijker om zelf het vervoer naar het werk te regelen. De grensarbeiders reden met eigen auto of reisden met andermans auto mee. ${ }^{33}$ Gedurende de gehele periode beschikten de meeste geïnterviewde vrouwelijke grensarbeiders niet over een eigen auto op het moment dat zij in Duitsland gingen werken. Omdat hun echtgenoten eveneens naar Duitsland pendelden, konden ze met hen meereizen. In dat opzicht waren deze vrouwen dus afhankelijk van hun man om in Duitsland te kunnen werken. In de periode van grote krapte op de Duitse arbeidsmarkt ontvingen de grensarbeiders die de auto's of busjes regelden en bestuurden een vergoeding. ${ }^{34}$ De moeder van Bep de Wever had bijvoorbeeld drie busjes die zij en haar twee dochters dagelijks tegen betaling naar Duitsland reden. Bep de Wever ontving hiervoor wekelijks 20 mark netto. Toen de arbeidsmarktomstandigheden vanaf het midden van de jaren 1970 verslechterden, verdween de prikkel voor Duitse werkgevers om het vervoer van Nederlandse werknemers te organiseren en financieren. Daardoor en door de krimp van de pendelstroom werd het sindsdien gebruikelijker om alleen naar het werk in Duitsland te reizen.

Op weg naar hun werk en terug naar huis passeerden de grensarbeiders dagelijks dan wel wekelijks twee maal de grens tussen Nederland en Duitsland. Daar waren zij zich op verschillende, in de tijd variërende, manieren van bewust. Grote delen van de Nederlands-Duitse grens waren lange tijd duidelijk gemarkeerd, wat de grensarbeiders eraan herinnerde dat zij op weg naar hun werk het grondgebied van een ander land betraden. De fysieke verschijning van de

33 Van de ondervraagde pendelaars in de NEI-enquête uit het begin van de jaren 1970 reisde ongeveer een derde met door de werkgever geregeld vervoer naar Duitsland. Het betrof hier vooral bouwvakkers (Van den Berg et al., De grenspendel in Limburg, 93).

34 Van de door het NEI in het begin van de jaren 1970 geënquêteerde grensarbeiders ontving bijna de helft een reiskostenvergoeding van de werkgever (Van den Berg et al., De grenspendel in Limburg, 95). 
grens heeft in de twintigste eeuw een aanzienlijke gedaanteverandering ondergaan. De metamorfose van de grens tussen het Nederlandse Kerkrade en het Duitse Herzogenrath, die over de as van de Nieuwstraat/Neustrasse loopt en die veel grensarbeiders dagelijks kruisten, vormt daarvan het meest sprekende voorbeeld. Tijdens de Eerste Wereldoorlog werd deze grens gemarkeerd door een twee meter hoge prikkeldraadafscheiding, die in de jaren 1920 werd verwijderd. Met het uitbreken van de Tweede Wereldoorlog werd er opnieuw een ruim twee meter hoge draadversperring opgericht. In het midden van de jaren 1950 werd deze vervangen door een afrastering van harmonicagaas van ruim een meter hoogte, die in 1968 werd ingeruild voor een richel bestaande uit veertig centimeter hoge betonblokken. Na het realiseren van de Europese Eenheidsmarkt in 1993 werden deze blokken weggehaald en bleven er alleen kleine zwarte nopjes op de weg over. In 1995 was de 'grenzeloze' Nieuwstraat een feit en was de grens nagenoeg onzichtbaar (zie ook de afbeeldingen op de volgende pagina). ${ }^{35}$ De gedaanteverandering van de grens komt terug in de verhalen van de grensarbeiders. In de jaren 1960 en 1970 stak Bep de Wever de Nieuwstraat over op weg naar haar werk. Zij noemt het harmonicagaas en de rand van betonblokken 'een stukje muur' en zegt dat Duitsland mede daarom 'toen nog echt het buitenland' was. Tot in de jaren 1990 deed de zichtbaarheid van deze grens de grensarbeiders duidelijk beseffen dat zij het buitenland betraden. Op andere plaatsen waren (officiële) grensovergangen herkenbaar door de aanwezigheid van douanekantoortjes en een slagboom. ${ }^{36}$ Sinds het openen van de grenzen in de jaren 1990 zijn deze onbemand achtergebleven of hebben ze een andere functie gekregen.

Naast de verschijningsvorm van de grens zelf deden andere materiële herkenningstekens de grensarbeiders beseffen dat zij de grens passeerden. Zij noemden bijvoorbeeld de andere bouwstijl, de afwijkende verkeersborden en het andere straatmeubilair in Duitsland. ${ }^{37}$ Daardoor waren ze zich ook na het verdwijnen van de duidelijk zichtbare grensmarkeringen bewust van het moment dat zij de grens overstaken.

Tot in de jaren 1990 manifesteerde de grens zich bovendien in de grenscontroles. De douaniers controleerden steekproefsgewijs de papieren en eventueel de bagage van de grensarbeiders. Verschillende geïnterviewde pendelaars stelden dat zij zelden of nooit werden aangehouden, omdat de douanebeambten hen kenden of wisten dat het grensarbeiders betrof, bijvoorbeeld gedurende de ochtendspits. Sef Heuts, die in de jaren 1980 bij een aantal Duitse supermarkten werkte, zegt dat hij zo weinig werd gecontroleerd dat hij op een dag tot de ontdekking kwam dat zijn paspoort reeds enige tijd was verlopen. De controlefrequentie was volgens de grensarbeiders verder afhankelijk van hun eigen houding en die van de betreffende douaniers. Zo vertelt Theo Lacroix dat de douaniers soms 'gewoon wat pest[t]en' en dat hij altijd op zijn tellen moest passen. Over een aanvaring met een douanebeambte vertelt hij:

Ik had een jerrycan met water in mijn auto staan, omdat ik problemen had met de radiateur. Die douanier zegt: 'Wat is dat?' Ja, ik zeg: 'Of dat nou Hollands of Duits water is, maar in elk geval water', om een beetje te jennen. Maar ja, daar schiet je niks mee op hè. Dan moest je tien meter verderop gaan staan, motorkap open, pas afgeven en dan kijken waar het motornummer stond. 
De Nieuwstraat/Neustrasse 1955/1956-1968. Bron: Gemeentearchief Kerkrade (nr. 01901).

De Nieuwstraat/Neustrasse 1968-1993. Bron: ibidem (nr. 01897).

De Nieuwstraat/Neustrasse sinds 1995. Bron: ibidem (nr. 01940).
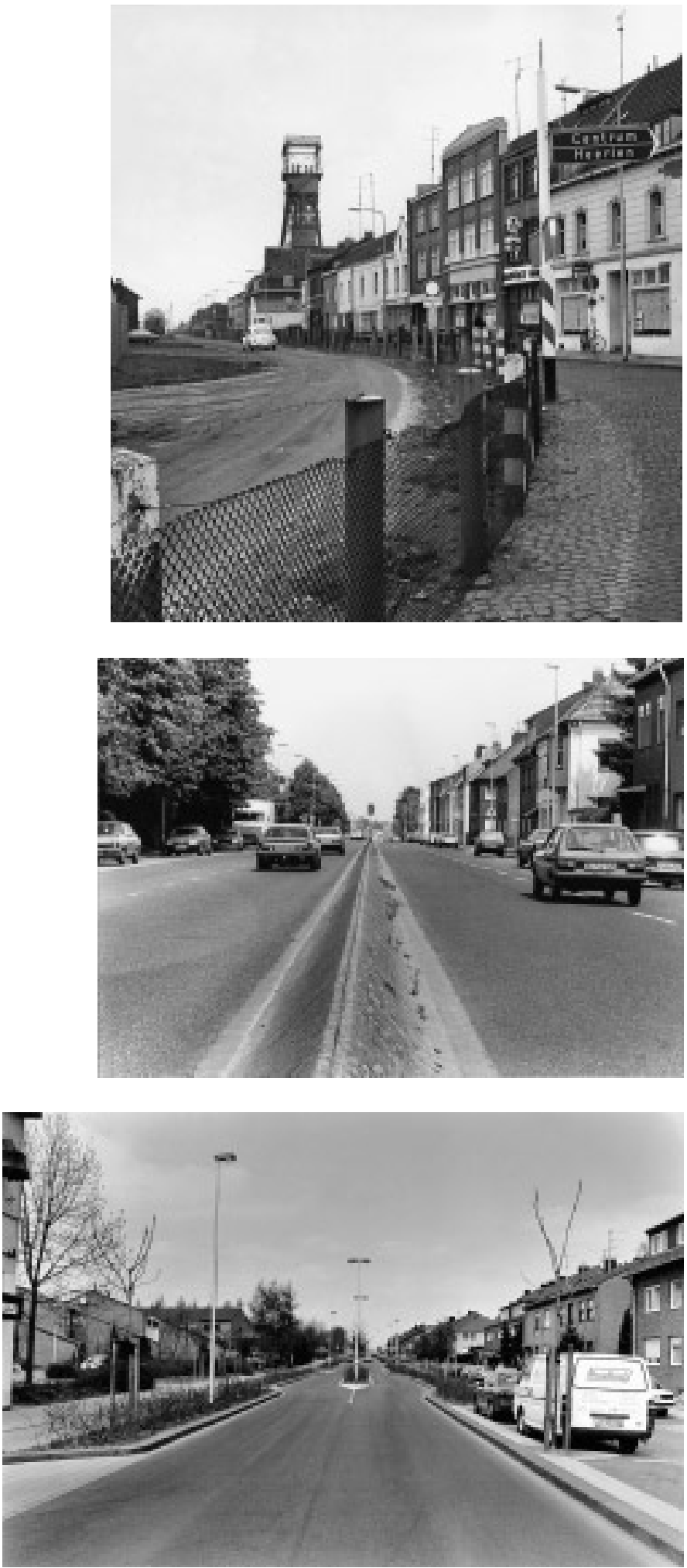
De douaniers leken het nodig te vinden de grensarbeiders bij tijd en wijle te attenderen op de grens en het belang van hun aanwezigheid. Volgens de meeste grensarbeiders gold dit zowel voor de Nederlandse als de Duitse douaniers. Duitse grenswachters werden echter vaak met andere ogen bekeken. Zo zegt Anton Hupkens dat het contact met de Nederlandse douanebeambten beter was dan dat met de Duitsers:

Ja, die Duitsers zijn gewoon allemaal wat stijver wat dat betreft. Ik noem het maar weer formeler. Die Nederlanders, ja, die waren toch wel een beetje soepeler. Daar kon je wel eens een grapje mee maken. Die accepteerden dat meer. Maar niet die Duitsers. Als die een uniform aan hebben, dan kun je maar beter zwijgen.

Hij interpreteert zijn ervaringen aan de grens aan de hand van als typisch Duits beschouwde eigenschappen als starheid en militarisme. Door deze stereotiepe karakteromschrijving af te zetten tegenover de manier waarop de Nederlandse douaniers zich gedroegen, reproduceert hij de grens in haar sociaal-culturele betekenis. Later in dit hoofdstuk zal blijken dat stereotiepe beelden van de Duitsers vaak terugkwamen in de interpretatie van hun gedrag.

De grensarbeiders karakteriseerden de grenscontroles doorgaans als zinloos en tijdrovend en zij vormden voor hen een bron van irritatie. Normaal gesproken duurde het oponthoud aan de grens ongeveer vijf tot tien minuten, maar door controles kon dit oplopen tot twee uur. Niettemin hadden sommigen, met name in de jaren 1960, wel iets te verbergen. In die tijd bestonden er grote prijsverschillen en strenge regels ten aanzien van de in- en uitvoer van bepaalde producten, zoals sigaretten en koffie..$^{38}$ Een aantal grensarbeiders smokkelde dergelijke producten de grens over voor Duitse collega's. Anderen hielden zich weliswaar steeds aan de maximaal toegestane hoeveelheid, maar doordat zij dagelijks de grens passeerden, konden ze in korte tijd toch relatief veel van deze producten meenemen. Andersom brachten grensarbeiders vanuit Duitsland dan weer sterke drank en elektronica mee naar Nederland. Zij zetten de grens als markering van verschillen in prijs en beschikbaarheid van producten dus zodanig naar hun hand dat zij als grenspendelaar behalve een beter loon nog andere extra inkomsten konden genereren.

Met de totstandkoming van de Europese interne markt (1993) en de implementatie van de Schengenovereenkomst (1995) zijn de grenscontroles zo goed als beëindigd. Sindsdien vinden er uitsluitend nog incidenteel zogenaamde 'vliegende controles' plaats. ${ }^{39}$ Desondanks maakte de fysieke herkenbaarheid van de grens dat de grensarbeiders zich bewust bleven van het feit dat zij een ander land betraden. Dat kleurde hun ervaringen in Duitsland.

\section{'IN DEN VREEMDE'}

Theo Lacroix: Ja, ik moet eerlijk zeggen: zo lang ik in Duitsland gewerkt heb, de laatste tien, vijftien jaar niet meer, maar ik had altijd het gevoel: ik kwam in een vreemde wereld terecht. Zo gauw ik over die streep bij het douanekantoor heen was, was ik in den vreemde.

Op weg naar hun werk werden grensarbeiders er telkens aan herinnerd dat zij de grens passeerden. Gedurende hun eerste periode in Duitsland zagen zij zich ook op andere momenten

$3^{8}$ In 1968 zijn de invoerrechten en contingentering in het kader van de Europese douane-unie afgeschaft (Spapens en Van Kemenade, De grens gemarkeerd, 81).

39 Zie ook Bort, 'European Borders in Transition', 66. 
met de grens geconfronteerd. Enkelen van hen gaven expliciet aan dat zij het gevoel hadden in een andere wereld terecht te komen zodra zij in Duitsland gingen werken. Nu gaat een nieuwe baan meestal vergezeld van enige onzekerheid. Onder de grensarbeiders werd deze echter versterkt doordat zij een ander land betraden. In het algemeen komt uit de interviews een beeld naar voren van de grensarbeiders als fremdkörper, die op een andere professionele context, een andere taal, andere regels en een ander 'volk' stuitten..$^{40}$ Ook hier was sprake van een paradoxale situatie. Doordat de grens werd overschreden, verloor zij aan betekenis als scheidslijn, maar tegelijkertijd won zij in die hoedanigheid juist daardoor aan belang in de beleving van de grensarbeiders.

\section{Professionele onzekerheid}

In hun beginperiode in Duitsland twijfelden veel grensarbeiders aan hun vakbekwaamheid. Dit kende verschillende, in de tijd verschuivende, achtergronden. Een gebrek aan opleiding en verschillen in opleidingssystemen en professionele conventies konden hen onzeker maken over hun geschiktheid voor het werk in Duitsland. Tot in de jaren 1970 zette de krappe arbeidsmarkt Duitse werkgevers er ook toe aan grensarbeiders zonder geschikte opleiding of werkervaring in te huren. ${ }^{41}$ Voordat Bep de Wever in de jaren 1960 in een Duits naaiatelier begon, had zij als huishoudelijke hulp en bij een elektronicafabriek in Nederland gewerkt. Eerder had zij op de huishoudschool alleen wat basale naaitechnieken geleerd, terwijl haar Duitse collega's een langere en op maat gesneden opleiding volgden of achter de rug hadden. Het gebrek aan opleiding maakte haar, net als andere grensarbeiders, onzeker over haar competentie. Leo Hamers zag dat anders. Hij brak aan het einde van de jaren 1950 zijn opleiding tot mijnwerker voortijdig af om in een Duitse spinnerij te gaan werken. Aangezien dit werk niet beviel, stapte hij na enkele maanden over naar de bouw. Hij noemt het Duitse systeem 'eerlijker', omdat het hem de gelegenheid bood het vak in de praktijk te leren. Op de krappe Duitse arbeidsmarkt was hij in staat zich op te werken van handlanger tot metselaar, tegelzetter en stratenmaker, iets dat hem in Nederland zonder passende opleiding vrijwel onmogelijk leek. De schaarste op de Duitse arbeidsmarkt bood dus kansen, maar het gebrek aan opleiding kon tevens onzekerheid over de vakbekwaamheid in de hand werken.

Door de verruiming en herstructurering van de arbeidsmarkt hadden de grensarbeiders in de jaren 1980 en 1990 meestal wel een passende opleiding nodig om werk te vinden in Duitsland. Het grotere belang van relevante opleidingen creëerde een nieuw probleem: de erkenning van de Nederlandse diploma's. Marion Leenders, die midden jaren 1990 als hoofdverpleegkundige in een Duits verzorgingstehuis ging werken, moest dit eerst rond zien te krijgen. Het was een lang en moeizaam proces, onder meer omdat zij haar opleiding al bijna twintig jaar eerder had afgerond. Bovendien bracht de erkenning van haar diploma kosten met zich mee die opliepen tot zo'n 120 Duitse mark. Uiteindelijk heeft dit in haar geval verder geen problemen opgeleverd, maar als afdelingshoofd maakte zij mee dat de diploma's van solliciterende Nederlandse ziekenverzorgers een lager niveau kregen toegekend dan in Nederland. Soms betekende dat een dermate grote achteruitgang, dat de persoon in kwestie

40 Dit betekent niet dat alle grensarbeiders hun onzekerheid allemaal benoemden of deze (in gelijke mate) op alle vier de punten hebben ervaren. Het betreft een algemeen beeld.

41 Zie ook Vreuls, 'Grenzüberschreitende Pendlerwanderungen', 7-8. 
afzag van werken in Duitsland. Diverse maatregelen op Europees niveau lijken hierin weinig verbetering te hebben gebracht. ${ }^{42}$

Voor sommige beroepsgroepen lag het opleidingsniveau in Nederland beduidend hoger dan in Duitsland, zoals in het geval van de fysiotherapeuten en logopedisten. Zij hadden een opleiding gevolgd aan het Nederlandse Hoger Beroepsonderwijs, terwijl het merendeel van hun Duitse collega's een opleiding in Duitsland had gevolgd die volgens de pendelaars qua niveau ongeveer gelijk stond aan het Nederlandse Middelbaar Beroepsonderwijs. Wouter Slootman, die in de jaren 1990 een aantal jaren als fysiotherapeut in de omgeving van Düren werkte, zei dat de Nederlandse fysiotherapeuten daarom zeer geliefd waren onder de Duitse patiënten:

Die [de patiënten] vonden het echt helemaal geweldig dat ze von... [Nederlandse fysiotherapeuten werden behandeld]. Ja, de kwaliteit van zorg die wij daar gaven was toch hoger dan een Duitse therapeut kon aanbieden.

Grensarbeiders in deze beroepen hebben zich inhoudelijk gezien nooit incapabel gevoeld. Dat gold eveneens voor de verpleegkundige Marion Leenders. Op basis van haar ervaring in Nederland vond zij dat de Duitse private ouderenzorg sterk achterliep bij de Nederlandse ouderenzorg en dat de Duitsers daarom nog wat van haar konden leren.

Dat wil niet zeggen dat grensarbeiders met een passende opleiding of voldoende werkervaring zich nooit onzeker voelden over hun capaciteiten. Sommigen schatten de waarde van het Duitse equivalent van hun opleiding hoger in. Theo Lacroix twijfelde in de jaren 1960 aan zijn vakbekwaamheid, omdat hij dacht dat het niveau van zijn opleiding tot metaalbewerker op de Technische Vakschool veel lager lag dan dat van de opleiding die zijn Duitse collega's hadden doorlopen. Anderen voelden zich onzeker omdat in Duitsland andere werkwijzen, normen en regels golden dan in Nederland. Voor Sef Heuts was dit een reden om niet direct een leidinggevende functie te accepteren. Nadat hij gedurende bijna twintig jaar een aantal Nederlandse levensmiddelenzaken had geleid, ging hij in de jaren 1980 bij een Duitse supermarkt werken. Mede omdat hij niet bekend was met het Duitse systeem weigerde hij in het begin een baan als assistent-bedrijfsleider. De verantwoordelijkheid maakte dat werk in zijn ogen 'te link'. Daarom is hij een trede lager ingestroomd als afdelingsleider.

Behalve met de inhoud van het werk, hadden diverse grensarbeiders, vooral in de jaren 1960 en 1970, moeite met het hoge werktempo in Duitsland. ${ }^{43}$ Dit viel Bep de Wever in de jaren 1960 erg zwaar:

En dan was ik zo kapot, dat kun je je helemaal niet voorstellen. Hè, van die hele dag dat gepees. Dat ik bij mijn eigen dacht: Mijn god Bep... En vooral die eerste tijd heb ik dat heel erg gehad. Hè, dat ik dacht: dit hou je niet vol.

De hoge werkdruk hing samen met de toenmalige krapte op de Duitse arbeidsmarkt en het akkoordloonsysteem in de Duitse bouw en de industrie, waarbij de betaling afhing van de productiviteit. De akkoorden werden steeds verder aangescherpt, waardoor de grensarbeiders alsmaar meer moesten produceren tegen een lagere betaling. Dit betekende dat zij hard moes-

42 Voor deze maatregelen: zie http://europa.eu.int/scadplus/printversion/en/cha/coooozd.htm (19 december 2004). Over de mate waarin problemen rond de erkenning van diploma's grensarbeid onder Nederlandse en Duitse hoger opgeleiden belemmeren, zie Janssen en De Gijsel, 'Do Dutch-German Euregional labour markets really exist?', 14-15.

43 Zie ook Van den Berg, De grenspendel in Limburg, 132; Vreuls, 'Grenzüberschreitende Pendlerwanderungen', 9. 
ten werken en lange dagen maakten. ${ }^{44}$ In dit systeem mochten zij pas gaan werken nadat zij helemaal waren ingewerkt. De inwerktijd bedroeg meestal enkele maanden. Daarbij ontvingen zij gewoonlijk een vast uurloon. De overgang van het uur- naar akkoordloon vormde weliswaar een zekere erkenning van geschiktheid, maar dat was niet altijd voldoende om de grensarbeiders helemaal stevig in hun schoenen te doen staan.

\section{Taalbarrière}

Door hun werkzaamheden over de grens kregen de grensarbeiders verder dagelijks met een andere taal te maken, die zij zeker in het begin veelal onvoldoende beheersten om zowel professioneel als sociaal gezien goed te kunnen meekomen op de werkvloer. Een deel van de grensarbeiders, zoals bouwvakkers en later bijvoorbeeld fysiotherapeuten, werkte hoofdzakelijk met Nederlandse collega's, maar ook zij kwamen onvermijdelijk met de Duitse taal in aanraking. Hoewel de dialecten van Zuid-Limburg en de Regio Aken veel gelijkenis vertonen, werden deze zeker niet altijd gesproken op het werk. Het gebruik van het dialect werd steeds minder gebruikelijk naarmate de grensarbeiders dieper in Duitsland werkten. Voorts spraken niet alle grensarbeiders of hun collega's een van de dialecten en was een goede beheersing van het Duits voor bepaalde beroepen, zoals logopedist, secretaresse en voorman, een vereiste om goed te kunnen functioneren.

De meeste grensarbeiders moesten dus Duits spreken en dikwijls ook schrijven op hun werk. Op school hadden zij meestal basale kennis van het Duits opgedaan, maar deze was over het algemeen ontoereikend om zich goed te kunnen redden. De beperkte beheersing van het Duits kon problemen opleveren bij het verrichten van de dagelijkse werkzaamheden. Theo Lacroix, die in de jaren 1960 als bankwerker bij een grote metaalfabriek in Aken ging werken, zei hierover:

Je hebt gewoon technisch Duits en technisch Nederlands. Daar zitje al eens mee in de knoop. Om een klein voorbeeldje te noemen. Ik was op die fabriek aan het werk in het begin, en die baas zegt tegen mij, ik vertaal het een beetje: 'Haal me maar een Bogen Schmirgel. Ja, godallemachtig. Eerstens wist ik niet wat een Bogen was... Hoe moet ik dat letterlijk vertalen? Dat is gewoon een vel schuurpapier. Dus ik ging naar die andere jongens toe, ik zeg: 'Wat is Schmirgel? Maar die spraken geen Hollands, ik was de enigste Nederlander die daar werkte, 'Ja, Schmirgel... Schmirgel is Schmirgel.' Ja sorry, maar.. Ik weer terug naar die baas en die natuurlijk beledigd want die dacht dat ik hem voor de gek hield.

Als de grenspendelaars instructies verkeerd of niet begrepen, konden er misverstanden ontstaan waardoor zij niet altijd in staat waren hun taken naar behoren uit te voeren. Thei Gulikers, die vanaf het einde van de jaren 1960 ongeveer zeven jaar lang bij verschillende Duitse bouwbedrijven werkte, vertelde dat hij in het begin van de jaren 1970 een trap verkeerd had ingemeten, doordat hij de Duitse woorden voor hoogte en breedte had verwisseld. Dergelijke incidenten deden zich ook in de jaren 1980 en 1990 voor.

Degenen die in de jaren 1980 en 1990 in Duitsland gingen werken, hadden vaker een hogere opleiding genoten en beter Duits geleerd, maar de Duitse taal speelde eveneens een grotere rol in hun werkzaamheden. Het meest uitgesproken voorbeeld daarvan is Françoise Pieter-

44 De door het NEI in 1972 geënquêteerde grensarbeiders waren gemiddeld 45 minuten langer van huis. De geënquêteerde grenspendelaars zouden echter amper meer overwerken dan de geënquêteerde niet-pendelaars. (Hendriks et al., De gevolgen van de grenspendel, D21, D25-27). 
se, die sinds het midden van de jaren 1990 als logopediste in Duitsland werkte en onder meer kinderen met taalachterstanden moest behandelen. Aanvankelijk kreeg zij soms commentaar uit haar werkomgeving:

Een arts heeft een keer tegen me gezegd: 'Ja', zegt ie, 'hoe kunt u iemand nou goed een taal aanleren als u de taal zelf niet beheerst?'

Een enkeling, zoals Niels Moonen die sinds het einde van de jaren 1990 als fysiotherapeut in Duitsland werkte, zei dat hij nooit kritiek heeft gehad op zijn aanvankelijk wat matige Duits. Integendeel, hij vertelde dat Duitse collega's en patiënten het erg waardeerden dat hij zijn best deed om Duits te spreken. Voor hem was de taal echter minder cruciaal om zijn werk goed uit te voeren en zoals we zagen hadden Nederlandse fysiotherapeuten dankzij hun relatief hoge opleiding een goede naam in Duitsland.

Verschillende pendelaars zeggen dat de beheersing van de Duitse taal tevens onmisbaar was voor een goede relatie met hun Duitse collega's. Ook in de onderlinge omgang konden de taalverschillen immers tot onbegrip en misverstanden leiden. Volgens de grensarbeiders kwam dit hun sociale contacten en assertiviteit niet ten goede. Zo begreep Bep de Wever de grappen van haar collega's niet altijd:

Dus ik sprak natuurlijk niet zo goed Duits als later hè. En ik zat een keertje zo met die stoel naar achter en ik was iets [naaiwerk] aan het uithalen, dat had ik verkeerd gedaan. En toen kwam die bedrijfsleider door de hallen heen en zei: 'Frau De Wever, Sie sitzen nicht zu Hause am Kamin!'45 En ik wist helemaal niet wat een 'Kamin' was! (lachend)

Andere grensarbeiders zeiden dat Duitse collega's hen uitlachten om hun gebrekkige Duits. Door het taalverschil verliepen de onderlinge contacten dus niet vlekkeloos en werd de grens gereproduceerd.

\section{Verwarring over wet- en regelgeving}

Zodra zij in Duitsland werkten, kwamen de grensarbeiders in aanraking met Duitse wet- en regelgeving en Duitse instanties die deze moesten uitvoeren. In het begin waren de meeste pendelaars volledig onbekend met de Duitse regels. Zij wisten niet hoe zaken rond ziektekostenverzekeringen, pensioenen en andere formaliteiten in Duitsland waren geregeld. ${ }^{46} \mathrm{De}$ grensarbeiders, zeker wanneer zij eerder in Nederland hadden gewerkt of hun partner en/of zijzelf naast het werk in Duitsland nog in Nederland werkte(n), bevonden zich bovendien in een zeer gecompliceerde positie. Zij vielen met hun gezin zowel onder de Nederlandse als de Duitse wet- en regelgeving. Beide landen hebben onafhankelijk van elkaar complexe sociale en fiscale stelsels ontwikkeld, die er met de hervorming van de welvaartsstaten niet minder ingewikkeld op zijn geworden. De politiek-wetenschappers Anderson en Bort stellen dat er ondanks het Europese integratieproces aan het begin van de éénentwintigste eeuw nog altijd sprake is van grote discrepanties tussen de wet- en regelgeving aan weerszijden van Europese grenzen. De regels kunnen daardoor op korte afstand grote verschillen vertonen. Wat aan de ene kant van de grens volkomen vanzelfsprekend is, kan voor personen aan de andere kant

45 'Mevrouw De Wever, u zit niet thuis bij de open haard!'

46 Tot 1970 hadden de grensarbeiders bijvoorbeeld een werkvergunning nodig om in Duitsland te mogen werken (Werner, 'Beschäftigung von Grenzarbeitnehmern', 29). 
van de grens onbegrijpelijk zijn. ${ }^{47}$ Voorts is bij de ontwikkeling van de welvaartsstaten in het algemeen geen rekening gehouden met de positie van de grensarbeiders. ${ }^{4}$ Gezien hun onbekendheid met de Duitse wet- en regelgeving en hun complexe formele positie voelden grensarbeiders zich in het begin van hun loopbaan in Duitsland nogal gedesoriënteerd in de wirwar van wet- en regelgeving.

De ingewikkelde wettelijke positie van de grenspendelaars vertaalde zich jaarlijks in een 'hele papierkraam' en 'rompslomp' ${ }^{49} \mathrm{Zij}$ moesten talloze formulieren invullen om de betaling van hun belastingen en de ontvangst van sociale zekerheidsuitkeringen in goede banen te leiden. Zo waren ze verplicht zowel een Duits als een Nederlands belastingformulier in te dienen en om Duits kindergeld te ontvangen moesten zij jaarlijks een verklaring afgeven over de school van hun kinderen.

Omdat de Duitslandgangers aanvankelijk geen greep kregen op hun positie in het web van wet- en regelgeving, troffen zij vaak maatregelen om problemen te voorkomen. Gerben Jongeneel nam bijvoorbeeld een belastingadviseur in de arm om zich ervan te verzekeren dat het Duitse belastingformulier correct werd ingevuld. Andere grensarbeiders werden lid van een Duitse vakbond, voor het geval 'er [...] een keer iets verkeerd mocht zijn' en 'om een beetje zekerheid te hebben'. ${ }^{\circ}$

Pendelaars die in de jaren 1960 en 1970 via koppelbazen of onderaannemers in Duitsland werkten, maakten zich extra zorgen over hun positie. Het beeld dat de geïnterviewde grensarbeiders van de koppelbaaspraktijken schetsten, stemt overeen met de verhalen die er in de jaren 1960 en 1970 in de regionale pers verschenen. ${ }^{51}$ Belangrijk verschil was wel dat zij meer nadruk legden op de eigen verantwoordelijkheid van de grensarbeiders. Volgens diverse pendelaars die in de jaren 1960 en 1970 in Duitsland werkten, stonden koppelbazen bekend als 'louche figuren' en 'bedriegers' en hadden de grensarbeiders die voor hen werkten beter moeten weten. ${ }^{52}$ Enkelen wezen er net als de pers op dat sommige pendelaars zelf fraudeerden door in Nederland een werkloosheidsuitkering te trekken en tegelijkertijd illegaal via een koppelbaas in Duitsland te werken. De grensarbeiders die hierover vertelden, waren van mening dat het lang niet altijd willoze en onwetende slachtoffers betrof, maar personen die wisten van de clandestiene praktijken van de koppelbazen en deze bewust negeerden of er zelf van probeerden te profiteren. Het werken voor een koppelbaas zou dan een bewuste keuze zijn geweest om in korte tijd veel geld te verdienen en daarbij bepaalde risico's voor lief te nemen. De meeste grensarbeiders distantieerden zich van deze praktijken door te benadrukken dat ze niets met de koppelbazen te maken wilden hebben en bewust voor meer zekerheid kozen door direct voor een Duitse werkgever te gaan werken. Pendelaars die wel voor koppelbazen hebben gewerkt, wezen er in de interviews op dat zij altijd controleerden of ze met een bonafide tussenpersoon te maken hadden. Toch hebben enkele grensarbeiders voor een malafide koppelbaas gewerkt. Pas na enige tijd ontdekten zij dat er bijvoorbeeld geen ziektekostenpremie voor hen was afgedragen. Zij wezen er nadrukkelijk op dat dit achter hun rug om gebeur-

\footnotetext{
47 Anderson en Bort, The Frontiers of het European Union, 74.

48 Wolters et al., Arbeid in beweging, 89 .

49 Zie Nico Stassen, Françoise Pieterse, Fred Wolters, Frank Schmitz.

50 Zie resp. Fred Wolters en Nico Stassen. Uit de enquête van het NEI van 1972 kwam ook naar voren dat men de kans op het uitblijven van een uitkering bij ziekte of werkloosheid in Duitsland groter achtte dan in Nederland (Hendriks et al., De gevolgen van de pendel, D39).

51 Voor een uitvoerige analyse van de berichtgeving over grenspendel in de regionale pers: zie hoofdstuk 5 .

52 Zie resp. Otto Welten en Thei Gulikers.
} 
de en aanleiding was om de arbeidsrelatie onmiddellijk te beëindigden. In het vervolg zouden zij nooit meer voor een koppelbaas werken of altijd controleren of hun premies werden voldaan. Ook deze grensarbeiders maakten duidelijk dat zij niet met de illegale koppelbaaspraktijken geassocieerd wilden worden.

\section{Sociale onzekerheid}

De grensforensen waren in veel gevallen, zeker in de jaren 1960 en 1970, hard nodig om de Duitse arbeidstekorten op te vangen. Toch voelden zij zich niet altijd welkom in hun nieuwe werkomgeving. De achtergronden daarvan verschoven door de jaren heen, maar de pendelaars verbonden het steeds met hun andere nationale herkomst. Sommige grensarbeiders die in de jaren 1960 en 1970 in Duitsland gingen werken, voelden zich buitengesloten. Bep de Wever vertelde:

Collega's die je toch een beetje behandelden als... ja, zoals wij nu vaak misschien wel tegen de Marokkanen of tegen de Turken aankijken. Je kwam toch van buiten. Je was geen Duitser.

Zij relateerde haar positie als outsider tevens aan haar gebrek aan opleiding, waardoor haar Duitse collega's op haar zouden hebben neergekeken.

Andere grensarbeiders die in dezelfde periode in Duitsland werkten, meenden dat Duitse collega's hen juist als een bedreiging beschouwden. Zij wezen in dit verband op het akkoordloonsysteem zoals dat in de bouw en de industrie werd gehanteerd. De Duitsers zouden gevreesd hebben dat de grenspendelaars hun productiviteit evenaarden of voorbijstreefden, wat tot een aanscherping van de prestatieafspraken kon leiden. De Nederlanders zouden de akkoorden dan 'kapot maken'. ${ }^{33}$ Theo Lacroix, die in de jaren 1960 als metaalbewerker bij een grote fabriek in Aken ging werken, zei hier problemen mee te hebben gehad. Helemaal in het begin ondervond hij nauwelijks moeilijkheden, omdat hij niet kon tippen aan het werktempo van zijn collega's. Zodra hij hen als 'vreemde eend in de bijt' echter qua productiviteit passeerde, veranderde hun houding en werd hij doelwit van pesterijen. De combinatie van het betalingssysteem en de Nederlandse herkomst zou in zijn ogen dus tot conflicten met Duitse collega's hebben geleid.

Door de verruiming en de herstructurering van de arbeidsmarkt was een geschikte opleiding of passende werkervaring sinds de jaren 1970 steeds meer een vereiste om een baan te vinden in Duitsland. Zoals we zagen hadden Nederlandse fysiotherapeuten of logopedisten over het algemeen een betere opleiding doorlopen dan hun Duitse collega's. Toch zeiden zij niet als bedreiging te zijn beschouwd. Zij werkten echter veelal bij Nederlandse praktijken en hadden daardoor overwegend Nederlandse collega's. Robert Storcken, die in het begin van de jaren 1980 als syteemtechnicus bij een klein informaticabedrijf ging werken, zei wel als gevaar te zijn gezien. Hij had het gevoel dat zijn Duitse collega's hem verweten 'hun' banen in te pikken in een tijd waarin het toch al niet goed ging met de arbeidsmarkt. Sef Heuts, die in de jaren 1980 bij een Duitse supermarkt werd bevorderd tot assistent-bedrijfsleider, vertelde verder dat een aantal Duitse collega's het niet accepteerde dat hij als Nederlander een hogere positie bekleedde. 
Volgens diverse geïnterviewde grensarbeiders werden zij dus door hun andere nationale herkomst niet altijd geacht hetzelfde of een hoger niveau dan hun Duitse collega's te bereiken. Hoewel zij de grens in fysiek en sociaal-economisch opzicht overschreden, zagen zij een sociale barrière tegenover zichzelf opgeworpen. Duitse collega's zouden hen als buitenstaanders beschouwen, die de gevestigde sociale orde en hun positie daarin zouden aantasten. Zij zouden zich daarom volgens de grensarbeiders hooghartig opstellen en duidelijk maken dat de grenspendelaars niet dezelfde of een hogere positie behoorden in te nemen. ${ }^{54}$ De houding van hun collega's hoefde echter niet noodzakelijkerwijs voort te komen uit de Nederlandse herkomst van de grensarbeiders. Zij kon eveneens samenhangen met het persoonlijke karakter van de collega's of de specifieke bedrijfscultuur. Dat de grensarbeiders deze wel in verband brachten met hun andere nationale herkomst, duidt op de aanwezigheid van de grens als scheidslijn in de interpretatie van hun ervaringen.

Mede doordat zij zich op basis van hun Nederlandse herkomst negatief bejegend voelden, waren diverse pendelaars in eerste instantie geneigd hun Nederlandse collega's op te zoeken. Gezien het grote aantal Nederlandse pendelaars was het in de jaren 1960 en 1970 makkelijker om met elkaar op te trekken dan in de decennia daarna. Op basis van de identieke nationale herkomst, dezelfde taal en hun gelijksoortige ervaringen, veronderstelden de grensarbeiders onderling een vergelijkbaar referentiekader. De geografen Dörrenbacher en Schulz constateerden recentelijk iets soortgelijks onder Franse grensarbeiders in het Duitse Saarland. Door hun gebrekkige beheersing van de Duitse taal en een benadeling in termen van werktijden, promoties en ontslag, vormden de Franse grenspendelaars 'eilanden' in de Duitse fabrieken. ${ }^{5}$ Van dergelijke vormen van discriminatie maakten de geïnterviewde Duitslandgangers geen melding.

Bep de Wever zei dat zij behalve met de Nederlanders eerst contact zocht met andere buitenlandse collega's, die in de jaren 1960 en begin jaren 1970 in groten getale aanwezig waren:

In eerste instantie ging je met de Nederlanders om. En ik had dan een Spaanse vriendin, die dan ook Duits sprak, waar ik toen mee samenwerkte. Je zag dat je eerst bij de minderheden ging. Want die anderen dat was die meerderheid, waar je steeds tegenop boksen moest.

De gepercipieerde minderheidspositie wakkerde bij Bep de Wever gevoelens van lotsverbondenheid aan ten opzichte van andere buitenlanders. Deze waren dus niet noodzakelijkerwijs gebonden aan de gelijke nationale achtergrond, maar konden tevens voortkomen uit een nietDuitse herkomst. In het algemeen kan geconcludeerd worden dat de grensarbeiders de grens als sociale scheidslijn zagen, en haar juist daardoor in die zin ook reproduceerden.

De grensarbeiders overschreden de grens weliswaar in fysieke en sociaal-economische zin, maar voelden zich er op andere fronten in versterkte mate mee geconfronteerd. Hun onzekerheid hing niet alleen samen met aanwijsbare nationale verschillen, zoals de andere taal en wet- en regelgeving, maar ook met andere zaken, zoals de houding van hun Duitse collega's. ${ }^{56}$ Hoewel de nationale bepaaldheid van de ervaren verschillen niet altijd onomstotelijk vaststond, schreven de grensarbeiders deze primair toe aan de andere nationale context. Zij pers- 
ten hun ervaringen in het sjabloon van de verwachtingen die zij hadden op basis van een nationaal referentiekader, dat voortkwam uit hun overwegend nationale socialisatie. ${ }^{57}$ Deze makkte dat zij een zekere afstand ervoeren tussen het Nederlandse 'hier' en het Duitse 'daar'. In eigen land hadden zij het idee de heersende conventies te kennen, waardoor ze er daar op konden vertrouwen te weten hoe de wereld in elkaar stak, wat ze daarin van anderen konden verwachten en wat er van henzelf werd verwacht. Dat is vergelijkbaar met wat de socioloog Giddens 'ontologische zekerheid' noemt. ${ }^{8}$ Doordat zij buiten de gebaande paden traden, voelden de Duitslandgangers zich aanvankelijk onwennig in hun nieuwe rol en omgeving. Zij interpreteerden hun ervaringen vanuit een nationaal referentiekader en reproduceerden daarmee de grens in haar sociaal-culturele dimensie zowel in hun percepties als praktijken.

\section{TOENADERING EN DISTANTIËRING}

Lia Hoffman: Dat is voor ons geen exotisch land meer, doordat wij waarschijnlijk ook door het werk zo verweven zijn met Duitsland.

Naarmate de grensarbeiders langere tijd in Duitsland werkten, ebden de gevoelens van onzekerheid weg. Lia Hoffman, die aan het einde van de jaren 1960 als secretaresse bij een vleesverwerkende fabriek ging werken en na een half jaar overstapte naar een vergelijkbare baan bij een metaalfabriek, stelde dat zij gaandeweg meer vertrouwd raakte met de situatie in Duitsland en daar beter op kon inspelen. De grensarbeiders raakten ingewerkt op professioneel, linguïstisch, formeel en sociaal vlak, en konden daardoor steeds beter functioneren aan de overzijde van de grens. Niettemin zal uit de beschrijvingen van de grensarbeiders blijken dat de grens daarbij niet simpelweg aan belang verloor. De betekenis van de grens maakte een transformatie door en werd op verschillende punten gereproduceerd.

Het is niet precies te zeggen hoe lang dit inburgeringsproces duurde. De grensarbeiders deden hier geen uitspraken over. Het kreeg geleidelijk, in verschillende snelheden en grotendeels onbewust zijn beslag. Bovendien makten niet alle grensarbeiders hetzelfde eenduidige proces door. Eerder is gebleken dat sommige grensarbeiders zich vanaf het begin bijvoorbeeld helemaal geen zorgen maakten over hun professionele kwaliteiten. Bij anderen hield de onzekerheid aan en was zij zelfs reden om de werkzaamheden in Duitsland te beëindigen. Ook waren er grensarbeiders die tussentijds enige tijd in Nederland of België werkten. Zo werkte Lia Hoffman enkele jaren bij een Akense textielmachinefabriek, waarna zij haar werkzaamheden in verband met de geboorte van haar kinderen tijdelijk neerlegde en vervolgens, nadat ze even in Nederland had gewerkt, weer bij het betreffende Duitse bedrijf terugkeerde.

\section{Professionalisering}

$\mathrm{Na}$ enige tijd in Duitsland te hebben gewerkt raakten de grensarbeiders langzaam ingewerkt. Zoals gezegd werd dit in de jaren 1960 en 1970 in de industrie en de bouw normaliter gemarkeerd door de overgang van een uurloon naar een akkoordloon. Op dat moment werden zij als volledig vakbekwaam beschouwd. De grensarbeiders hadden dan dikwijls nog enige tijd no- 
dig om aan de als hoog ervaren werkdruk te wennen. Voor Anja Klinkers, die als veertienjarige in het midden van de jaren 196o in een Duitse spinnerij was gaan werken, was deze na acht jaar nog reden om haar werkzaamheden in Duitsland te beëindigen.

Daarnaast vormde zowel in de jaren 1960 en 1970 als in de jaren 1980 en 1990 de expliciet uitgesproken waardering van superieuren en patiënten of klanten een bevestiging voor de grensarbeiders dat zij aan de eisen voldeden. Dergelijke complimenten waren volgens hen in Duitsland veel gebruikelijker dan in Nederland. Ook de resultaten van de NEI-enquête uit 1972 wezen uit dat de meeste grensarbeiders zich in Duitsland meer erkend voelden dan in Nederland. ${ }^{59}$ De onzekerheid van de pendelaars over hun vakbekwaamheid nam daardoor af.

Bovendien werden verschillende geïnterviewde grensarbeiders in de gehele onderzoeksperiode bevorderd tot voorman, uitvoerder of afdelingshoofd. ${ }^{60}$ Theo Lacroix, die in de jaren 1960 en 1970 in een grote metaalfabriek werkte, was echter van mening dat hij ondanks zijn passende opleiding als Nederlander werd uitgesloten van de functie van voorman. Zijn superieuren zouden onrust onder de Duitse werknemers vrezen. Ofschoon hij zich onder zijn Duitse collega's langzaamaan geaccepteerd voelde, dacht hij dus dat hij als Nederlander nog altijd geen hoge(re) positie in de hiërarchie mocht innemen. Als sociale scheidslijn was de grens kennelijk nog niet helemaal uitgewist.

De inburgering in de professionele omgeving aan Duitse zijde van de grens ging samen met een veranderende verhouding met Nederland. Gerben Jongeneel, die ten tijde van het interview bijna dertig jaar in de Duitse bouw werkte, merkte op:

Ik moet eerlijk zeggen qua werkervaring en alles, ben ik eigenlijk een echte Duitser. Ik weet helemaal niet meer hoe het er hier in Nederland aan toegaat.

Hij was een zekere afstand tot Nederland gaan ervaren die een eventuele terugkeer naar Nederland in de weg stond. De jarenlange werkervaring in Duitsland ging dus gepaard met gevoelens van vervreemding van de situatie in Nederland. Zo werd de betekenis van de grens als scheidslijn opnieuw, maar nu in omgekeerde zin, bevestigd.

\section{Taalbeheersing}

Na verloop van tijd maakten de grensarbeiders zich ook de Duitse taal steeds meer eigen. Daardoor waren er minder misverstanden en konden de grensarbeiders hun opdrachten adequater uitvoeren. Françoise Pieterse, die in de vroege jaren 1990 als logopediste in Duitsland ging werken, kreeg in het begin kritiek op haar imperfecte beheersing van de Duitse taal. Na enige tijd had zij het Duits echter voldoende onder de knie om haar werkzaamheden naar behoren te kunnen uitvoeren. Daarna kreeg zij geen kritiek meer van anderen. Ondanks het belang van de taal in haar werk heeft zij, net als vrijwel alle andere grensarbeiders, geen taalcursus gevolgd, maar het Duits in de praktijk geleerd en door bijvoorbeeld veel naar Duitse televisieprogramma's te kijken. Enkele grensarbeiders gaven aan dat zij het Duits op den duur zo goed beheersten dat zij soms zelfs voor Duitser of Duitstalige Belg werden gehouden.

59 Hendriks et al., De gevolgen van de pendel op Duitsland, D11.

6o Uit de enquête van het NEI uit 1972 bleek overigens dat de grensarbeiders hun promotiekansen even groot inschatten als die van hun Duitse collega's (Hendriks et al., De gevolgen van de pendel op Duitsland, D34). 
Naarmate zij het Duits beter beheersten, ervoeren de grensarbeiders een grotere gelijkwaardigheid ten opzichte van hun Duitse collega's. Bep de Wever, die haar collega's in het begin niet altijd verstond, heeft zich naar eigen zeggen 'langzaam maar zeker boven deze underdogpositie uitgeworsteld' door beter Duits te leren spreken. Zij en andere grenspendelaars zeiden daardoor tevens mondiger te zijn geworden tegenover Duitse collega's en superieuren. ${ }^{61}$

Er was wel een duidelijk verschil in de beheersing van het Duits als spreektaal en als schrijftaal. Na enige tijd spraken de meeste grensarbeiders nagenoeg vloeiend Duits, maar schrijven bleef vaak een probleem. Zo liet Françoise Pieterse haar verslagen na meer dan tien jaar werkervaring in Duitsland nog altijd controleren door Duitse collega's. Dat gold ook voor anderen die langere tijd in Duitsland werkten en schriftelijk moesten rapporteren of corresponderen. De grensarbeiders vonden het Duits als schrijftaal zo moeilijk dat zij hun onzekerheid over hun beheersing daarvan niet helemaal kwijtraakten.

Bij diverse grensarbeiders raakte het Duits als spreektaal dermate ingeburgerd dat zij geregeld Duitse woorden en germanismen gebruikten wanneer zij Nederlands spraken, zelfs als zij al enige jaren niet meer in Duitsland werkten. Dat geldt vooral voor degenen die in de privé-sfeer een Limburgs dialect bezigden en dus zelden meer Nederlands spraken. De Limburgse dialecten lijken in bepaalde opzichten op het Duits, waardoor de grensarbeiders mogelijk reeds voordat zij in Duitsland werkten allerlei germanismen gebruikten. Toch weten zij dit zelf aan de vervreemding van de Nederlandse taal als gevolg van het werken in Duitsland. Niels Moonen, die in de jaren 1990 als fysiotherapeut in Duitsland ging werken, zei:

Ik moet zeggen dat mijn Nederlands ook slechter geworden is sinds ik in Duitsland werk. Ik gebruik heel veel verbasteringen. Dat ik heel vaak zeg: 'Ja, dat geeft het niet'. Van die stomme dingen. Tja, door de week praat ik meer Duits als [sic] Nederlands. Ook 's avonds moet ik echt helemaal terugschakelen. Ik heb ook vaak dromen in het Duits.

René Veldman vertelde dat zijn Nederlandse collega's en zijn vrouw hem om die reden altijd d'r Pruus noemden. Met het aanleren van de Duitse en het vervreemden van de Nederlandse taal, kon er volgens de grenspendelaars dus vermenging optreden. Daarmee onderscheidden de grenspendelaars zich zowel van hun Duitse collega's als van hun Nederlandse omgeving.

\section{Wegwijs in wet- en regelgeving}

De grensarbeiders waren in het begin volledig onbekend met de Duitse wet- en regelgeving en hun positie als grensforens, maar raakten ook hierover steeds beter geïnformeerd. Zij leerden hun rechten en plichten geleidelijk aan kennen en wisten hoe ze de benodigde Duitse formulieren moesten invullen. Eerder getroffen voorzorgsmaatregelen, zoals het inhuren van een belastingadviseur, werden daarmee overbodig. Fred Wolters, die ten tijde van het interview al meer dan dertig jaar in Duitsland werkte, was in eerste instantie 'als rugdekking' lid van de vakbond geworden. Na verloop van tijd benaderden personen die in Duitsland wilden gaan werken hem zelf om advies. Kennelijk ging hij nu door voor expert. Grensarbeiders raakten zo goed wegwijs in het woud van wet- en regelgeving dat zij nieuwe of potentiële grensarbeiders in hun sociale omgeving konden voorlichten. Sommigen werden zelfs actief in inspraakorganen op hun werk. 
De media vormden een belangrijke bron van informatie over de Nederlandse en de Duitse wet- en regelgeving. Om op de hoogte te blijven van het beleid in beide landen, volgden veel grensarbeiders zowel het Nederlandse als het Duitse journaal en lazen zij op het werk dikwijls een Duitse krant. Verder raakten de pendelaars na verloop van tijd beter bekend met het netwerk van overheidsinstanties en andere organisaties die zij bij onduidelijkheden konden benaderen. Verschillende grensarbeiders zijn lid geworden van de Vereniging Europese Grenslandbewoners (VEG). ${ }^{62}$ Anderen klopten met vragen onder meer aan bij de Eures-loketten en het Bureau Duitse Zaken (BDZ). ${ }^{6}$ Vanwege de complexiteit van de materie kregen zij ook daar echter niet altijd een pasklaar antwoord.

De onzekerheid over hun positie in het web van de Nederlandse en Duitse wet- en regelgeving verdween niet helemaal. Soms was de aanhoudende onduidelijkheid reden om de werkzaamheden in Duitsland te beëindigen. Rond zijn veertigste begon softwareontwikkelaar Anton Hupkens zich zorgen te maken over zijn pensioen. Reden genoeg om in Nederland werk te zoeken. Toen hij in feite al een baan in Nederland had geaccepteerd, bood zijn Duitse werkgever hem aan extra maatregelen te treffen om zijn pensioen te waarborgen. Daardoor is hij overgehaald om toch in Duitsland te blijven werken. Thei Gulikers, die vanaf het einde van de jaren 1960 tot het midden van de jaren 1970 in de Duitse bouw werkte, werd de onzekerheid rond de Duitse wet- en regelgeving op den duur te veel:

En d'r was nog een probleem: de Duitse verzekering. Dus als je afgekeurd was in Duitsland, dat was ook moeilijk. Dan kreeg je een wachttijd van zestig maanden ${ }^{64}$ eer je de uitkering volledig kreeg. Ik weet niet hoe die tussenregeling was. En ik had daar geen problemen, maar ik was daar toch niet gerust op. En daarom heb ik ontslag genomen en ben ik hier in Nederland gaan werken.

Over het algemeen raakten de grensarbeiders meer en meer vertrouwd met het Duitse stelsel en hun rechten en plichten. Parallel daaraan trad ook op dit gebied een zekere vervreemding op van Nederland. Niels Moonen, die in de jaren 1990 als fysiotherapeut in Duitsland ging werken, ziet zijn groeiende onbekendheid met de Nederlandse wet- en regelgeving als obstakel om in Nederland te gaan werken:

Zo veel werkervaring had ik niet toen ik in Duitsland begon. Dus daardoor weet ik niet beter. [...] Nou goed, dat is ook wel de reden dat ik nu zoiets heb van: als ik terug zou gaan naar Nederland dan zou ik me toch echt wel heel erg moeten bijspijkeren op dat gebied [van de wet- en regelgeving]. Ja goed, dat is ook een bepaalde rem om... Stel ik zou deze baan niet meer leuk vinden, dan zou ik eerder in Duitsland verder zoeken dan in Nederland.

Naarmate de grensarbeiders beter bekend raakten met hun juridische positie, werden zij zich bewuster van institutionele discrepanties tussen Nederland en Duitsland. Die hadden zij lang niet allemaal voorzien toen zij besloten in Duitsland te gaan werken. Voor degenen die in de jaren 1980 en 1990 in Duitsland gingen werken, mag dit erg opmerkelijk worden genoemd ge-

\footnotetext{
62 Voor meer over de Vereniging Europese Grenslandbewoners (VEG): zie hoofdstuk 5.

63 Bureau Duitse Zaken (BDZ) is onderdeel van de Sociale Verzekeringsbank en regelt sociale zekerheidsafdrachten en -uitkeringen van de Duitslandgangers, zoals de kinderbijslag en de oudedagsvoorziening. BDZ produceert ook informatiemateriaal, bijv. Werken en de sociale verzekering in Duitsland.

64 Bedoeld wordt dat een grensarbeider om voor invaliditeitsrente in aanmerking te komen minimaal zestig maanden in Duitsland verzekerd moest zijn geweest. De Europese verordening 1408/71 regelde echter dat hierbij ook de in Nederland gewerkte tijdvakken werden meegerekend (zie Sociale Verzekeringspositie van grensarbeiders, 8).
} 
zien de aandacht die de regionale pers er destijds aan besteedde. Kennelijk had dit eerder niet hun interesse of heeft het hen er niet van weerhouden om in Duitsland te gaan werken.

Hun positie tussen twee afwijkende systemen van wet- en regelgeving had volgens de grensarbeiders een aantal nadelen. Zo kon het moeilijk zijn om met een Duits inkomen een hypotheek te krijgen in Nederland en kwamen de pendelaars niet in aanmerking voor de hypotheekrenteaftrek als hun partner niet in Nederland werkte. Bovendien was de Duitse toelage voor studerende kinderen lager dan die in Nederland. ${ }^{65}$ In het begin van de jaren 1980 stelde de geograaf Vreuls op basis van zijn enquête dat grensarbeiders zich niet altijd bewust waren van de eventuele financiële nadelen van het pendelen, of deze als onbelangrijk beschouwden. Belastingproblemen zouden wel dikwijls reden zijn om te stoppen met pendelen. ${ }^{66}$ In de enquête van de geografe Soutif uit 1995 gaven diverse Zuid-Limburgse respondenten aan in verband met dergelijke problemen weer naar Nederland te willen terugkeren. ${ }^{67}$ Voor de hier geïnterviewde grensarbeiders vormden de consequenties van de verschillen in wet- en regelgeving zelden aanleiding om er een punt achter te zetten. Dat is op drie manieren te verklaren. Allereerst maakten vooral in de jaren 1960 en 1970 de hoge Duitse lonen veel goed. Op de tweede plaats waren de problemen veelal onvoorzien en stapelden zij zich geleidelijk aan op, waardoor er meestal geen directe aanleiding was om de werkzaamheden in Duitsland te beëindigen. Ten derde konden de verschillen tussen het Duitse en het Nederlandse systeem ook gunstig uitpakken voor de grensarbeiders. Dat was niet alleen afhankelijk van het soort regeling maar ook van de periode.

Ondanks de maatregelen die 'Europa' in de loop der jaren heeft genomen om grensoverschrijdende arbeidsmobiliteit te versoepelen, gaf een aantal grensarbeiders aan dat de problemen zich in de laatste decennia concentreerden. Dat heeft te maken met de grotere loonverschillen in de jaren 1960 en 1970, waardoor de mogelijke financiële nadelen destijds minder aandacht trokken. Daarnaast is de complexiteit van de Nederlandse en de Duitse welvaartsstaat in de loop der jaren toegenomen en gingen veel grensarbeiders in de jaren 1980 en 1990 met pensioen, waarbij zich een aantal problemen voordeed. Deze worden later in dit hoofdstuk besproken. De impact van de verschillen tussen de Nederlandse en de Duitse weten regelgeving veranderde daarmee zowel historisch gezien als in het traject dat de grensarbeiders doorliepen.

Dat systeemverschillen door de jaren heen meer of minder geld konden opbrengen, komt pregnant tot uitdrukking in de schommelende wisselkoersen. Aangezien de grensarbeiders hun loon tot 1999 in Duitse marken kregen uitgekeerd, moesten zij altijd fikse bedragen omwisselen. Een koersstijging of -daling van enkele centen kon daardoor al ingrijpende consequenties hebben. Edgar Beens, die in het begin van de jaren 1970 in Duitsland ging werken, zei vanwege de lage koers van de mark ten opzichte van de gulden in die tijd extra diensten te hebben gedraaid om voldoende te verdienen. Toen de mark later in waarde steeg, was dat niet meer nodig en genoot hij een goed inkomen. De uitbetaling in marken bracht wel altijd praktische problemen met zich mee. De grensarbeiders die via koppelbazen werkten, kregen hun

65 Zie ook Vreuls, Grenzüberschreitende Pendlerwanderungen', 9; Sociale Verzekeringspositie van grensarbeiders 13; Wolters et al., Arbeid in beweging, 89-90; Soutif, 'Domicile-travail', 130-131; voor een overzicht van de problemen waar de grensarbeiders sinds de jaren 1990 tegenaan liepen zie bijvoorbeeld Van Dam en De Grip, De Euregionale arbeidsmarkt, 7-23; Commissie grensarbeiders, Rapport van de Commissie grensarbeiders, 33-51; Weerepas, 'Grensoverschrijdende Arbeid in de Euregio'.

66 Vreuls, 'Grenzüberschreitende Pendlerwanderungen', 9-10.

67 Het betrof hier Zuid-Limburgers die in Duitsland of België werkten (Soutif, 'Domicile-travail', 134-135). 
loon contant uitbetaald. Anderen kregen hun loon op een bankrekening gestort. Aangezien overmaking naar een Nederlandse bankrekening kosten met zich meebracht, openden zij meestal een rekening in Duitsland. ${ }^{68}$ Iedere week of maand moest er dan een hele logistieke operatie op touw worden gezet om hun loon op een Nederlandse bankrekening te storten. De grensarbeiders namen maandelijks vrijwel hun volledige loon op in marken en zetten het vervolgens aan de grens om in guldens. Het overgebleven geldbedrag stortten zij op een Nederlandse bankrekening. Om verzekerd te zijn van de beste koers wisselden zij hun loon doorgaans niet om bij hun Duitse of Nederlandse bank, maar bij kleinere wisselkantoortjes direct aan de grens. Het gros van de geïnterviewde pendelaars toog daarvoor naar de grens bij Kerkrade, waar bij een café en een winkel een relatief goede koers en minder provisie werd berekend. ${ }^{69}$ Met de koppeling van de gulden aan de mark aan het einde van de jaren 1970 kwam er een einde aan de grote wisselkoersverschillen. Sinds de girale invoering van de euro in 1999 zijn deze volledig van de baan. ${ }^{70}$

Hoewel de systeemverschillen zowel voor- als nadelige consequenties konden hebben, overheerst de verontwaardiging over hetgeen de grensarbeiders is onthouden. Net als in de regionale dagbladen vanaf het einde van de jaren 1970 kreeg de Duitslandpendel onder de grensarbeiders zelf de connotatie van onrecht. Zij voelden zich gediscrimineerd, doordat zij op grond van hun werk of arbeidsverleden in Duitsland anders werden behandeld dan degenen die in eigen land werkten, en daar nadelen van ondervonden. Voormalig grensarbeider Theo Lacroix sprak in deze context van een onderscheid tussen grensarbeiders en 'normale mensen'. Het gevoel van onrecht werd gevoed door de gedachte dat veel grensarbeiders in de periode dat de Zuid-Limburgse arbeidsmarkt in grote moeilijkheden verkeerde, hun verantwoordelijkheid hadden genomen door een baan in Duitsland te accepteren en geen uitkering te (gaan) trekken.

Net als de opiniemakers in de regionale dagbladen sinds het einde van de jaren 1970 weten de geïnterviewde grensarbeiders de moeilijkheden die zij ondervonden zowel aan de nationale als de Europese autoriteiten. Zij vonden dat de Nederlandse overheid te weinig oog had voor hun problemen. Dat verklaarden ze uit de kleine omvang van de pendelstroom en het feit dat zij in de periferie van het land woonden. Ze voelden zich te marginaal. 'Die mensen in Den Haag weten helemaal niet wat een grensganger is' aldus Theo Lacroix. Volgens Marion Leenders 'kun je daar [in de Nederlandse politiek] niet mee scoren'. Daarnaast werd er in de ogen van de pendelaars vanuit de Europese Unie te weinig ondernomen om de nationale sociale en fiscale systemen meer op één lijn te krijgen. Zij beschouwden zichzelf als degenen die Europa in de praktijk brachten, maar voelden zich in de steek gelaten door zowel de Europese als de nationale autoriteiten.

Hoewel de grensarbeiders na verloop van tijd beter op de hoogte waren van hun formele positie, bleef de grens als institutionele scheidslijn een streep trekken door hun dagelijks leven. Zij kwamen los van het Nederlands grondgebied, maar bleven daar tegelijkertijd aan gebonden en raakten zo verstrikt in het web van de ongelijksoortige en alsmaar complexere nationale wet- en regelgevingen.

68 Zie ook Commissie van de Europese Gemeenschappen, Mededeling van de Commissie inzake de levens- en arbeidsvoorwaarden, 36; Van Dam en De Grip, De Euregionale arbeidsmarkt, 16.

69 Over wisselkantoren in cafés aan de grensovergang Locht-Horbach zie ook Spapens en Van Kemenade, De grens gemarkeerd, 239240.

70 Zestos, European Monetary Integration, 62-63. 


\section{Grensoverschrijding en grensbewaking}

Alhoewel ze niet altijd een goede start maakten, zeggen de meeste grensarbeiders dat zij op den duur goede contacten hadden met hun collega's. De omgang met Nederlanders bleef dikwijls gehandhaafd en vaak zagen zij elkaar ook buiten het werk. Dat de weekpendelaars uit de jaren 1960 en 1970 meer contact hadden met hun Nederlandse en andere buitenlandse collega's dan met Duitse collega's is niet meer dan logisch. Zij overnachten immers gezamenlijk bij het werk, terwijl hun Duitse collega's dagelijks naar huis terugkeerden. In de jaren 1990 werkten de fysiotherapeuten en logopedisten meestal in overwegend Nederlandse praktijken, waardoor ook zij vooral met Nederlandse collega's van doen hadden.

Naarmate de grensarbeiders het Duits beter beheersten en zij zich in hun beroepsuitoefening gelijkwaardiger voelden aan hun Duitse collega's, traden zij makkelijker en meer met hen in contact. In de jaren 1960 en 1970 gingen de pendelaars zich daardoor onderscheiden van andere buitenlandse collega's. Otto Welten, die in de jaren 1960 en 1970 in de Duitse bouw werkte, zei:

Nederlanders waren op den duur ook geen gastarbeiders hè? Je hoorde d'r gewoon bij. Als je het over een gastarbeider had, dan had je het over een Joegoslaaf of een Pool of noem maar op. Maar een Nederlander meestal niet, tenminste onder het werkvolk. Nederlanders die waren wat anders, die hoorden toch bij de Duitsers.

Hij heeft weliswaar de Duitse nationaliteit, maar is in Nederland opgegroeid en beschouwt zichzelf als Nederlander. In vergelijking met de gastarbeiders, zouden de Nederlanders meer gemeen hebben met hun Duitse collega's. Welten verklaarde dit uit de naar verhouding betere beheersing van de Duitse taal onder de grensarbeiders en de hogere posities die zij binnen de bedrijven bekleedden. In tegenstelling tot de meeste gastarbeiders, die in de regel handlanger of hulparbeider bleven, werkten de grensarbeiders zich dikwijls op tot vergelijkbare functies als de Duitsers. Bovendien zou het referentiekader van de grensarbeiders betrekkelijk veel overlap vertonen met dat van de Duitsers. Zo spraken en grapten zij onderling over muziek en televisieprogramma's die zowel in Nederland als in Duitsland bekend waren. ${ }^{71}$ In de jaren 1980 en 1990 was het verschil in taalbeheersing en competenties tussen de grensarbeiders en andere buitenlandse werknemers grotendeels verdwenen. Duitsland trok niet meer op grote schaal en over grote afstanden buitenlandse arbeidskrachten aan en een geschikte opleiding werd steeds meer een voorwaarde om in Duitsland te kunnen werken.

De Nederlandse pendelaars die in de jaren 1960 en 1970 in Duitsland werkten, vertoonden wel grote verschillen in de contacten die zij met de Duitse collega's onderhielden. Daarbij trekken de geïnterviewde grensarbeiders een scherpe scheidslijn tussen de Limburgers en de 'Hollanders', dat wil zeggen personen uit andere delen van Nederland. De grote arbeidstekorten en de hoge lonen lokten in de jaren 1960 en 1970 ook talloze arbeidskrachten uit bijvoorbeeld Noord-Brabant, Gelderland en Overijssel naar Duitsland. ${ }^{72}$ René Veldman, die vanaf het einde van de jaren 1960 tot en met het einde van de jaren 1990 in een grote Duitse

71 Hetzelfde gold volgens sommigen voor de grensarbeiders uit de Belgische Duitstalige Gemeenschap die in Duitsland werkten. Zij spraken natuurlijk sowieso al dezelfde taal en vertoonden in professioneel en cultureel opzicht ook meer gelijkenissen met de Duitsers.

72 Zie bijv. CBS, Sociale Maandstatistiek 1970/11, 563-564. 
metaalfabriek werkte, zei dat collega's uit Amsterdam en Noord-Brabant 'niet met Duitsers konden omgaan'. Limburg, en dan met name het zuidelijk deel van de provincie, zou als overgangszone naar Duitsland fungeren. Deze pendelaars, die meestal in Limburg waren geboren en getogen, refereerden daarbij aan grensoverschrijdende familiebanden, het gebruik van Duitse media in Limburg, een met het Duitse grensgebied gedeeld regionaal verleden en het vergelijkbare dialect. De uit Kerkrade afkomstige Louis Franssen zag de lokale bevolking als 'halve Duitsers'. Er zou dus een grotere verwantschap bestaan tussen de Zuid-Limburgers en de 'Pruisen', zoals zij de Duitsers in dit verband doorgaans noemden, dan tussen de 'Hollanders' en de Duitsers. Deze grensarbeiders construeerden een Limburgse identiteit door erop te wijzen dat zij anders waren dan de rest van Nederland en enige gelijkenis vertoonden met de Duitsers. ${ }^{73}$ Hun ervaringen in Duitsland konden deze versterken doordat zij Nederland op basis daarvan met andere ogen waren gaan bekijken. Zo stelden zij dat de Nederlanders waren doorgeslagen in hun assertiviteit, die sommigen gelijk stelden aan brutaliteit, en in de overlegcultuur, die als inefficiënt werd getypeerd. Dan herkenden deze pendelaars zich toch meer in 'de' Duitse beleefdheid en daadkracht.

Terwijl de contacten met Duitse collega's na verloop van tijd verbeterden, bleven deze bij veel grensarbeiders beperkt tot de werkvloer. Fysiotherapeut Wouter Slootman, die in de jaren 1990 enkele jaren in Duitsland werkte, zegt:

Het was in principe gewoon daar werken en dan 's avonds weer terug in Nederland. Hier had je je contacten en in Duitsland eigenlijk niet.

Het privé-leven van Wouter Slootman speelde zich aan Nederlandse zijde van de grens af, waardoor de grens als sociale scheidslijn werd bevestigd. Op implicietere wijze gebeurde dat tevens in de eerder beschreven manieren waarop de grensarbeiders naar hun werk reisden. Hoewel zij onderweg dikwijls woonplaatsen van Duitse collega's passeerden, reden de grenspendelaars vrijwel uitsluitend met Nederlandse collega's of alleen naar hun werk. Zij vormden als het ware mobiele enclaves die de grens in sociaal opzicht reproduceerden.

Een deel van de grensarbeiders ontmoette wel Duitse collega's buiten het werk. In de NEIenquête van 1972 betrof het ongeveer een derde van de respondenten. ${ }^{74}$ Enkele geïnterviewde grensarbeiders namen bijvoorbeeld met hun Duitse collega's deel aan gezamenlijk of door werkgevers georganiseerde activiteiten, zoals etentjes of activiteiten van een bedrijfssportvereniging. Sommigen hadden op individuele basis contact met Duitse collega's en bezochten hen ook thuis. ${ }^{75}$

Naast hun werk gingen de grensarbeiders de grens vaker over voor andere doeleinden, bijvoorbeeld om boodschappen te doen, te tanken en te recreëren. Om geld te besparen zetten zij hun loon niet volledig om in guldens, maar besteedden zij een deel rechtstreeks in Duitsland. Sommigen maakten in de jaren 1990 ook gebruik van de Duitse gezondheidszorg, die zij dikwijls als beter dan de Nederlandse beschouwden. Verder gingen zij meer naar Duitse televisieprogramma's kijken en lazen zij op het werk dikwijls een Duitse krant. Zoals we zagen was het mediagebruik in het begin vaak een manier om hun Duits te verbeteren en om op de hoog-

$75 \mathrm{Er}$ is geen eenduidige verklaring te geven voor de intiemere contacten die deze grensarbeiders met de Duitsers onderhielden. Zo zegt de een bijvoorbeeld erg geïnteresseerd te zijn in het buitenland, terwijl de ander het vooral als een verplichting zag af en toe bij elkaar op visite te gaan. 
te te blijven van het Duitse sociale en fiscale beleid. Maar het had ook een sociale functie: het was een manier om op te hoogte te raken van wat er in Duitsland speelde, om zo mee te kunnen praten met Duitse collega's.

De antropologen Donnan en Wilson stellen dat bij personen die een grens overschrijden het bijbehorende onderscheid tussen 'wij' en 'zij' kan vervagen. ${ }^{76}$ Blijkens onderzoek van Renckstorf en Lange uit 1990 kan contact tussen Nederlanders en Duitsers de beeldvorming over Duitsers in positieve zin doen veranderen. ${ }^{77}$ De dagelijkse interactie met Duitsers heeft enkele grensarbeiders er inderdaad toe aangezet hun negatieve beeld van de Duitsers in de Tweede Wereldoorlog bij te stellen. Louis Franssen, die vanaf de jaren 1970 tot en met de jaren 1990 bij een grote metaalfabriek werkte, zei daarover:

Als je met die Duitsers praatte... dat waren eigenlijk net zo'n gewone mensen als wij. Als die in de oorlog hadden durven zeggen van: 'Dat doe ik niet', dan waren ze verdwenen. Dat waren toch eigenlijk ook maar arme sodemieters. Want als je ze hoorde vertellen over als ze op transport gezet werden naar Rusland of weet ik wat, daar kreeg je toch medelijden mee. Dan dacht je bij je eigen: ja, hoe heb je dat eigenlijk kunnen overleven? [...] Want toen ze krijgsgevangenen werden, die oudere jongens waar wij dus mee werkten enzo, die hebben soms drie weken ergens gestaan op een trein... en daar keek niemand naar om. In die Siberische kou!

Hoewel de Duitsers in Nederland vaak als 'fout' in de oorlog worden bestempeld, gaven hij en een aantal andere grenspendelaars aan hun ideeën daarover op basis van de persoonlijke verhalen van collega's en patiënten te hebben genuanceerd. Sommige grensarbeiders zeiden bepaalde 'karaktertrekken' van 'de' Duitsers te hebben overgenomen, waardoor zij zich gingen onderscheiden van andere Nederlanders. Zo dacht Fred Wolters, die sinds het midden van de jaren 1970 als radiologisch diagnostisch laborant in een Duits ziekenhuis werkte en zich had opgewerkt tot afdelingshoofd, dat hij een andere (werk)mentaliteit had ontwikkeld, waardoor hij niet meer in Nederland zou kunnen aarden.

Toch betekende de toenadering, sociaal maar ook mentaal, niet dat de grensarbeiders zich één voelden met de Duitsers en zich niet langer met Nederland identificeerden. Integendeel, zij attendeerden veelvuldig op de onderlinge verschillen. De Duitsers zouden er andere gebruiken, omgangsvormen en een ander karakter op nahouden. Verschillende geïnterviewde pendelaars gingen uitgebreid in op afwijkende eet- en drinkgewoonten. Voor Duitsers was het bijvoorbeeld gangbaar om tijdens de lunch een warme maaltijd te gebruiken, terwijl de grensarbeiders vaak een boterham aten. Pendelaars die in de bouw en de metaalindustrie werkten, wezen op buitensporig drankgebruik van Duitse collega's op het werk. Zij gaven aan mee te hebben gedronken om zichzelf niet buiten spel te zetten, zij het met mate. Maar het waren niet altijd de grensarbeiders die zich aanpasten. Louis Franssen hield in de jaren 1970 met een aantal andere Nederlandse collega's in een grote metaalfabriek vast aan de 'Nederlandse' gewoonte om 's ochtends een koffiepauze in te lassen. Hij vertelt dat ook Duitse collega's hier op den duur aan deelnamen.

Los van de afwijkende gewoonten benadrukten de grensarbeiders vooral de andere omgangsvormen en de andere aard van 'de' Duitsers. Een terugkerend punt zijn de formele en hierarchische omgangsvormen van de Duitsers. Het was volgens de grensarbeiders bijvoor- 
beeld lang niet altijd gebruikelijk hun collega's te tutoyeren, laat staan superieuren met je en jij aan te spreken. Zij bestempelen dit als 'typisch Duits' ${ }^{78}$ Het is hier niet zozeer interessant of de Duitsers werkelijk anders waren, maar in hoeverre de grensarbeiders hen als zodanig percipieerden. ${ }^{79}$ Nationale stereotypen speelden hierbij een cruciale rol. Verwijzingen naar hetgeen zij tegenkwamen als echt Duits, duiden op een interpretatie vanuit een begrensd referentiekader. Dat blijkt ook uit het feit dat zij, ondanks mogelijke regionale verschillen, de Duitsers hier als een eenheid benaderden. Andere, zowel positieve als negatieve, stereotyperingen die de grensarbeiders hanteerden, waren die van de Duitsers als een gastvrij, beleefd, punctueel, gedisciplineerd, bureaucratisch, star, prestatiegericht, militaristisch, autoritair, gezagsgetrouw en arrogant volk. Intensieve omgang met Duitse collega's in de privé-sfeer leek deze stereotypen niet te ontkrachten. Anton Hupkens was zelfs van mening dat 'het typisch Duitse' bij persoonlijk contact alleen maar uitdrukkelijker op de voorgrond trad. Ook Otto Welten, die een Duitse vader had maar in Nederland is opgegroeid, en Lia Hoffman, die met een Duitser is getrouwd, hanteerden dergelijke algemene classificaties. In de jaren 1990 constateerde de sociologe Van Beek dat Zuid-Limburgers die de grens geregeld overschreden tal van vooroordelen over de Duitsers koesterden. ${ }^{80}$ Verwachtingen ten aanzien van Duitsers kunnen de ervaring van het contact met personen uit deze groep kleuren. Door selectieve waarneming kunnen vooral de ervaringen die in het verwachtingspatroon passen worden opgemerkt, geaccepteerd en onthouden. ${ }^{{ }_{1}}$ Uiteraard waren er uitzonderingen. Zo gaf Nico Stassen aan dat zijn verwachtingen omtrent de formele omgang met Duitsers werden weerlegd, paste Françoise Pieterse de stereotypen waarmee zij Duitsers in het algemeen omschreef, niet toe op haar directe collega's, en gebruikte Niels Moonen ze vooral om oudere Duitsers te omschrijven.

Bij degenen die nationale stereotypen hanteerden om de Duitsers te karakteriseren, ging het echter niet zozeer om een typering van de Duitsers als wel om de articulatie van hun Nederlandse identiteit. De bewaking van de grens als symbolische scheidslijn valt goed te illustreren aan de hand van de veel voorkomende verwijzingen naar de Tweede Wereldoorlog. Verschillende grensarbeiders hadden hun beeld van de Duitsers in de oorlog bijgesteld. Voor anderen vormde het beeld van de 'foute' Duitsers een belangrijk ankerpunt bij de duiding van hun ervaringen met Duitsers. Robert Storcken, die in de jaren 1980 als systeemtechnicus in Duitsland werkte, zei het volgende:

De mentaliteit van Duitsers is anders dan die van Nederlanders. Ja goed, die Hitler heeft dat ook zo ver kunnen schoppen omdat hij door die mentaliteit werd gedragen. En dat zou je in Nederland nooit voor mekaar krijgen denk ik. Daar zijn we veel te nuchter voor. Een Duitser.. geef ze maar een jasje en een petje en het is geregeld. Dan voelen ze zich een hele pief. Al zitten ze maar bij een parkeergarage te wachten, op de boel te passen. Geef ze maar een muts en een jasje en het is geregeld.

Zoals we bij de beschrijving van de omgang met Duitse douanebeambten al zagen, wees Anton Hupkens eveneens op het veronderstelde Duitse ontzag voor uniformen. Dit zou voortkomen uit 'het' Duitse militarisme, dat hen volgens Robert Storcken in de oorlog had gestort.

\footnotetext{
Zie Niels Moonen.

Zie ook Paasi, Territories, boundaries and consciousness, 61 (en hoofdstuk 2).

Van Beek, Samenwerking?, 86-89, 91.

Dekker, Nationaal favoritisme, 9-10; zie ook Barth, 'Introduction', 9-10, 30.
} 
Ook typeringen van Duitsers als autoritair en gezagsgetrouw werden in verband gebracht met de oorlog. Het ging er hier niet zozeer om 'de' Duitsers te karakteriseren, maar om zichzelf daar als Nederlander van te onderscheiden. Robert Storcken trok in zijn beschrijving een duidelijke grens tussen Duitsers en Nederlanders, die veel minder gevoelig zouden zijn voor militair vertoon. Door zich op bepaalde punten van de Duitsers af te zetten en zijn Nederlandse achtergrond daarbij te benadrukken, creëerde hij een contrasterend beeld van zichzelf als Nederlander en werd de grens in symbolische zin gereproduceerd. Anton Hupkens benadrukte: 'ik ben en blijf altijd een Nederlander', om duidelijk te maken dat hij zich, ondanks zijn betrekkelijk intensieve contacten met Duitse collega's, niet met de Duitsers identificeerde. Diverse grensarbeiders gaven aan dat hun emotionele binding met Nederland reden was om niet in Duitsland te gaan wonen. Zoals we in hoofdstuk 2 zagen, constateert de historicus Martínez op basis van onderzoek in het Mexicaans-Amerikaanse grensgebied ook dat de meeste grensbewoners ondanks grensoverschrijdende contacten, neigen naar een aanhoudende en zelfs versterkte identificatie met hun woonland. ${ }^{82}$

Het is opvallend dat de verwijzingen naar de Tweede Wereldoorlog sterk leeftijdsgebonden zijn. Grensarbeiders die ten tijde van het interview jonger waren dan veertig en ouder waren dan vijfenzeventig jaar, zeiden hier niets over. Het ontbreken van referenties aan de oorlog onder de jongeren is te verklaren uit de afstand tot de oorlog, en het daarmee samenhangende mildere Nederlandse klimaat ten aanzien van de Duitsers waarin deze personen zijn opgegroeid. ${ }^{83}$ Voor de oudere grensarbeiders strookt de afwezigheid van verwijzingen naar de oorlog niet met het algemene Nederlandse beeld. Zij hebben de oorlog allemaal bewust meegemakkt. Een van hen heeft gedurende de oorlog zelfs als dwangarbeider in het Ruhrgebied gewerkt. Een ander had een broer die als dwangarbeider vlak over de Duitse grens werkte en daar in verband met zijn huwelijk met een Duitse is blijven wonen. De afwezigheid van referenties aan de oorlog in hun beschrijvingen van het werken in Duitsland kan verbonden zijn met het feit dat zij als grensbewoners de Duitsers gedurende de oorlog van dichtbij hebben meegemaakt en daardoor een wat gedifferentieerder beeld hebben van hun positie en gedrag.

De grensarbeiders profileerden zich niet alleen in het interview, maar ook op de werkvloer en daarbuiten als Nederlanders. Barbara Cornelissen vertelde bijvoorbeeld over een herdenking van de Duitse werkgeversvoorzitter Martin Schleyer die in 1979 samen met zijn chauffeur door de Rote Armee Fraktion (RAF) werd ontvoerd en vermoord:

Voor Martin Schleyer moesten we opeens een minuut stilte houden op het werk. Dat heb ik dus niet gedaan. Martin Schleyer was dus iemand die in de oorlog mensen uitgesorteerd had in een KZ [concentratiekamp]: die komen meteen in de gaskamer en die niet. Dat had ik dus in de Nederlandse krant gelezen. Dat stond niet in de Duitse krant. En daar heb ik de collega's dan ook over geïnformeerd. Kijk, voor die chauffeur wilde ik wel een minuut stilte houden, maar voor hem niet. Maar van die hoge baas [...] moest ik me dus die drie minuten stilte houden. Maar daar had ik dus wat op bedacht, ik denk: je houdt die minuut stilte niet. En toen had ik dus een telmachine, als je daar zo'n moeilijke berekening in stopte, dan bleef dat dus doorratelen en rekenen. Dus dat heb ik gedaan. Die heeft dus één van de drie minuten gerateld. Dat was mijn stil [sic] protest.

82 Martínez, Border People, o.a. 83, 307.

83 Zie Wielenga, Van vijand tot bondgenoot, 305-397; uit een enquête uit 1996 kwam ook naar voren dat Nederlanders in de leeftijd van 16 tot 30 jaar meer gelijkenissen met Duitsers zagen dan oudere Nederlanders (Van Oudenhoven, 'Nederlanders over Duitsers', 310311 . 
En toen kwam dus die hoogste chef uit dat heilig verblijf, want die hoorde dat natuurlijk. Verder was het helemaal stil. En toen: 'Ratel, ratel, ratel', daar ging mijn machientje. Toen trok ie de stekker d'ruit. En toen liep ie weer weg! [lacht] Maar hij heeft er nooit wat van gezegd. Ik heb hem toen dat Nederlandse krantenartikel daar neergelegd. Ik denk: hij bekijkt het maar. Had je me maar niet moeten aannemen, dacht ik bij mezelf! [lacht] [...] En ik heb dus heel duidelijk laten blijken dat ik voor die chauffeur wel een minuut stilte, maar niet voor die.. die.. Maar het was dus echt drie minuten stilte voor de Martin Schleyer en niet voor z'n chauffeur, terwijl ze alle twee dood waren. En dan denk ik: typisch Duitsland hè.

Zij verzette zich tegelijkertijd tegen 'de' Duitse taboesfeer rond de Tweede Wereldoorlog en 'de' Duitse hiërarchie, en benadrukte de andere manier waarop daar in Nederland mee zou worden omgegaan. Met een Nederlandse collega grapte ze dat zij 'ontwikkelingshulp' boden, door 'die Duitsers een beetje democratie bij te brengen' en hiërarchische grenzen die er op het werk bestonden aan hun laars te lappen. Door zich van 'de' Duitse hiërarchie en gezagsgetrouwheid te distantiëren, construeerde Barbara Cornelissen een beeld van zichzelfals democratische en vrije Nederlandse. Dit wijst op een zekere morele superioriteit ten opzichte van de Duitsers, die Nederlanders in dit verband niet vreemd is. ${ }^{84}$

Barbara Cornelissen gaf aan dat haar Nederlandse herkomst juist maakte dat haar afwijkende gedrag werd geaccepteerd. Het articuleren van de Nederlandse nationaliteit bleek dus niet noodzakelijkerwijs een wig te drijven tussen de grensarbeiders en hun Duitse collega's. Sterker nog, voor verschillende grensforensen was het juist een manier om contact met hen te maken. Voor buschauffeur Edgar Beens waren internationale voetbalkampioenschappen een goede gelegenheid om zich op zijn werk als Nederlander te manifesteren. Na de finale van de wereldkampioenschappen in 1974, die het Nederlands elftal verloor van Duitsland, droeg hij een rouwband naar het werk. Veertien jaar later kon hij zijn gram halen toen het Nederlands elftal de Duitsers versloeg in de halve finale van de Europese kampioenschappen. Daags erna droeg hij triomfantelijk een oranje shirt met de opdruk 'Holland' naar zijn werk. De geografe Strüver ziet bij de 'Nederduitsers', Nederlanders die recentelijk in groten getale in het Duitse grensgebied zijn gaan wonen, vergelijkbare nationale symbolen om hun Nederlandse herkomst te benadrukken, zoals windmolentjes in de tuin..$^{85}$ Uit de verhalen van de grensarbeiders blijkt dat deze niet per se alleen maar een afstand hoeven te scheppen. De NederlandsDuitse rivaliteit rond de voetbalkampioenschappen bood Edgar Beens en zijn Duitse collega's bij uitstek een gezamenlijk referentiekader en een gedeelde ervaring. ${ }^{86} \mathrm{Zij}$ bekeken de televisie-uitzendingen rond de betreffende kampioenschappen samen. Ook andere grensarbeiders gebruikten de grens als symbolische scheidslijn om een brug te slaan naar Duitse collega's. Zij maakten bijvoorbeeld grappen over hun afwijkende nationale herkomst en veronderstelde volksaard. Dat is vergelijkbaar met wat de antropologe Zabusky vond op basis van etnografisch onderzoek bij de European Space Agency. Nationale stereotypen boden daar een gemeenschappelijk betekeniskader aan de collega's die afkomstig waren uit verschillende Europese landen, en konden op die manier de onderlinge contacten faciliteren. ${ }^{87}$

84 Wielenga, Van vijand tot bondgenoot, 348-349, 371-373, 378-380. Nederlanders die in de eerste decennia na de Tweede Wereldoorlog opgroeiden, instrumentaliseerden het beeld van 'de' Duitsers in de Tweede Wereldoorlog met name in de jaren 1960 ook om zichzelf af te zetten tegen het als volgzaam beschouwde Nederlandse establishment (Ibidem, 327).

85 Strüver, 'Spheres of Transnationalism', 335-336.

86 Over de Nederlands-Duitse rivaliteit rond voetbalwedstrijden, zie ook Wielenga, Van vijand tot bondgenoot, 382-385; Van Houtum en Van Dam, 'Topophilia or Topoporno?'.

87 Zabusky, 'Boundaries at work'; vgl. Barth, 'Introduction', 10. 
Terwijl de grensarbeiders zich ten opzichte van de Duitsers meestal als Nederlanders (of zelfs 'Hollanders') presenteerden, profileerden zij zich tegenover de rest van Nederland ('Holland') vaak als Limburgers, die meer verwantschap met de Duitsers zouden vertonen. Een gelaagde identiteit, waarbij afhankelijk van de context één identiteit domineert, is natuurlijk niet uniek voor grensarbeiders ${ }^{88}$ Kenmerkend voor grensbewoners is wel een ambivalente identiteit waarin twee landen met elkaar lijken te concurreren. ${ }^{89}$ De socioloog Vila heeft laten zien hoe grensbewoners aan de Mexicaanse zijde van de Mexicaans-Amerikaanse grens zich in vergelijking met de Verenigde Staten een nationale identiteit aanmeten, terwijl ze in vergelijking met Mexico een regionale identiteit aannemen waarin Amerikaanse elementen zijn verweven..$^{\circ}$

De grensarbeiders raakten dus langzaamaan ingewerkt in Duitsland. Ze maakten zich de Duitse conventies en de benodigde competenties om zich te kunnen redden eigen, waardoor hun onzekerheid verminderde. Na verloop van tijd konden zij beter inschatten wat hen in Duitsland te wachten stond en hoe zij daarop behoorden te reageren, en werden bepaalde zaken vanzelfsprekend, zelfs routine. Kennelijk bevonden zij zich op den duur opnieuw in een situatie die Giddens als 'ontologische zekerheid' typeert. ${ }^{11}$ Uit de verhalen van de grensarbeiders blijkt dat de inburgering in Duitsland gepaard ging met gevoelens van vervreemding van de Nederlandse zijde van de grens. De barrièrewerking van de grens werd daarmee als het ware omgedraaid. De mate waarin zij zich de Duitse conventies toeëigenden, was niet per se gelijk aan de mate waarin zij van Nederland vervreemdden en er trad tevens vermenging op. In het laveren tussen Nederland en Duitsland ontwikkelden de grensarbeiders dus eveneens hybride praktijken. Dat betekent niet dat zij hun nationale referentiekaders loslieten of zich met de Duitsers gingen identificeren. In vergelijking met de rest van Nederland wezen ze weliswaar op enige overeenkomsten met de Duitsers, maar als Nederlanders namen zij duidelijk afstand van 'het' Duitse karakter en gedrag. De symbolische aspecten van de grens kenden dus een grote mate van duurzaamheid. Desondanks kon juist het refereren aan de grens als scheidslijn verbindend werken. Ook hier kan van een paradox van de grens worden gesproken.

\section{DE PENDEL TOT STILSTAND?}

Ten tijde van de interviews werkten de meeste grensarbeiders niet meer in Duitsland. Hoewel zij het werk in Duitsland in het begin veelal als iets tijdelijks zagen, hielden zij dit meestal langer dan tien jaar aan. De loopbanen in Duitsland werden zowel gedwongen als uit eigen beweging beëindigd. Een aantal grensarbeiders was door lichamelijke beperkingen niet meer in staat om te werken. Anderen, zowel in de bouw, de metaalindustrie als in de IT-sector, kregen in tijden van economische teruggang hun ontslag aangezegd. Sommige grensarbeiders waren van mening dat nationale herkomst daarbij een rol speelde. Zo denkt Anton Hupkens,

88 Rose, 'Place and identity'.

89 Martínez, Border People, 18-21; Stoddard, 'Frontiers, Borders and Border Segmentation', 8-9; Strassoldo, 'Border Studies', 152; Wilson en Donnan, 'Nation, state and identity', 10-11.

90 Vila, Crossing borders, reinforcing borders, 21-80; over de meervoudige identiteit van de bevolking van Franse grensgebieden: zie Lawrence et al., "Degrees of Foreigness", 70-71.

91 Giddens, The constitution of society, 6o-64. 
wiens werkgever eerder alles in het werk stelde om hem voor het bedrijf te behouden, dat hij uiteindelijk mede vanwege zijn 'Nederlandse' assertiviteit is ontslagen. Ook hier projecteert hij een nationaal betekeniskader op zijn ervaringen met het werken in Duitsland.

Grensarbeiders die hun werkzaamheden in Duitsland op eigen initiatief beëindigden, deden dat om twee redenen. Allereerst zetten economische problemen bedrijven sinds de jaren 1970 aan tot reorganisaties, die dikwijls gepaard gingen met een verplaatsing van (een deel van) de activiteiten. In tijden van recessie waren er tevens minder bouwprojecten. Zo kwamen werkplekken soms dieper in Duitsland en dus verder van huis te liggen. De pendelaars waren meestal niet bereid te verhuizen. De toenemende reisafstand was voor hen reden hun loopbaan in Duitsland af te breken. Een tweede reden om te stoppen waren de eerder besproken zorgen over hun juridische positie en professionele bekwaamheid.

Als gevolg van de economische problemen vanaf de jaren 1970 was het niet altijd mogelijk om een nieuwe baan in Duitsland te vinden, maar daar waren ook lang niet alle grensarbeiders op uit. Het vertrek uit Duitsland was desondanks niet altijd definitief. Verschillende grensarbeiders keerden na enkele maanden of jaren wegens gebrek aan of onvrede over hun werk in Nederland of België weer terug in een vergelijkbare functie of zelfs bij dezelfde werkgever.

$\mathrm{Na}$ het beëindigen van hun werkzaamheden in Duitsland pakten de (voormalige) grensarbeiders hun leven zoals dat er voorafgaand aan het pendelen had uitgezien, niet zo maar weer op. De pendel kwam niet helemaal tot stilstand, maar bleef op drie manieren een rol spelen in hun dagelijks leven: zij dachten een veranderingsproces te hebben doorgemaakt; ze hadden nog steeds te maken met hun ingewikkelde positie in de Nederlandse en Duitse wet- en regelgeving; en ze bleven de grens in andere sferen van het dagelijks leven overschrijden.

De verwachting dat zij na terugkeer in Nederland weer zouden moeten wennen aan de taal, de beroepsuitoefening, de wet- en regelgeving en de omgangsvormen, bleek uit te komen. Anton Hupkens, die in Duitsland had gestudeerd en er vervolgens bijna dertig jaar had gewerkt, ervoer aanpassingsproblemen met de taal. Later heeft hij hier zijn voordeel mee gedaan. Toen hij een eigen bedrijf opzette, kon hij zijn kennis van de Duitse taal en de bekendheid met de Duitse manier van zaken doen, goed aanwenden om naast de Nederlandse ook de Duitse markt te bereiken. Zo kon hij optimaal gebruik maken van zijn tussenpositie. Enkele ex-pendelaars stelden dat hun werkwijze en mentaliteit was veranderd en dat hun pendelverleden zo zijn sporen achterliet. Wim Ramakers werkte van 1957 tot en met 1959 in drie Duitse mijnen. Hij nam ontslag vanwege de hoge werkdruk en ging vervolgens in een Nederlandse mijn werken. Daarover zei hij:

Ik begon op de Domaniale [mijn] en iedereen wist: die komt van Duitsland. Als die anderen nog aan het werken waren, dan was ik al lang klaar. [...] Hier in Nederland had ik een luizenleventje tegenover in Duitsland. Waar ze hier in Nederland acht uur over werkten, dat deed ik in vier! Bij wijze van spreken. [...] Dan hadden ze het direct in de gaten: die komt van Duitsland.

Hoewel hij slechts korte tijd in Duitsland had gewerkt, zei hij zich het Duitse werktempo eigen te hebben gemaakt. Daarmee onderscheidde hij zich van zijn Nederlandse collega's, die dit ook aan zijn verblijf in Duitsland zouden hebben toegeschreven. Hij was echter tevens fysiek herkenbaar als voormalig grensarbeider, omdat hij zijn pendelverleden accentueerde door de eerste maanden zijn gele Duitse mijnwerkerspet te dragen in plaats van de zwarte die in Nederland gangbaar was. Deze voormalige grensarbeiders vonden dat zij waren veranderd ten opzichte van degenen die altijd in Nederland hadden gewerkt. Dat gold niet voor iedereen. 
Voor Robert Storcken, die in de jaren 1980 en 1990 in Duitsland werkte en zich in zijn verhalen over het werken in Duitsland sterk afzette tegen 'de' Duitse gebruiken en 'de' Duitse volksaard, betekende het einde van de grenspendel juist een 'opluchting'. Hij hoefde zich niet langer te voegen in 'de' Duitse conventies en kon weer zichzelf, dat wil zeggen Nederlander, zijn.

Voor Robert Storcken en anderen betekende het einde van de arbeidsrelatie met Duitsland tevens een bevrijding van alle 'papieren rompslomp' die met hun intermediaire positie gepaard ging. Niettemin werden zij rond of na hun vertrek uit Duitsland nog met hun complexe positie tussen het Nederlandse als het Duitse systeem van wet- en regelgeving geconfronteerd. Dat is de tweede manier waarop de grenspendel bleef doorwerken in het dagelijks leven van de voormalige grensarbeiders. Zo kwamen zieke of gehandicapte grensarbeiders door afwijkende keuringsnormen menigmaal niet in aanmerking voor een arbeidsongeschiktheidsuitkering uit Duitsland, terwijl zij deze over een eventueel in Nederland gewerkte periode wel ontvingen. Dit kon penibele financiële situaties tot gevolg hebben. ${ }^{92}$ Daarnaast ontstonden er moeilijkheden rond de pensionering van de pendelaars en hun partners. Gedurende de periode die zij in Duitsland werkten, waren hun niet-werkende echtgenoten niet verzekerd in het kader van de Nederlandse Algemene Ouderdomswet (AOW). Dit wordt 'het AOW-gat' genoemd. ${ }^{93}$ Sinds de jaren 1980 zijn de problemen rond de AOW stapsgewijs verholpen, ${ }^{94}$ maar het wekte nog altijd veel verontwaardiging onder de grensarbeiders. Otto Welten werkte in de jaren 1950, 1960 en 1970 respectievelijk in een Duitse mijn en bij diverse werkgevers in de Duitse bouw. Zijn echtgenote heeft nooit een betaalde baan gehad, maar werd in 2000 vanwege zijn zestienjarige arbeidsverleden in Duitsland 32 procent gekort op haar AOW:

Maar dat van mijn vrouw heb ik altijd abnormaal gevonden. Mijn buurvrouw heeft ook nooit gewerkt, en die kreeg wel honderd procent. Waarom kreeg mijn vrouw dan 32 procent minder?

Door het AOW-gat en andere problemen voelden grensarbeiders zich ook na het beëindigen van hun werkrelatie met Duitsland gediscrimineerd ten opzichte van degenen die (niet of) altijd in hun woonland hadden gewerkt. Behalve wanneer het om de afwijkende arbeidsongeschiktheidsnormen ging, hielden de ex-grensarbeiders vooral de Nederlandse overheid aansprakelijk voor het onrecht dat hen werd aangedaan. Dit strookt met het vertoog in de regionale dagbladen in de jaren 1980 en 1990 en is verklaarbaar uit het feit dat de voormalige grenspendelaars zich primair verbonden voelden met de Nederlandse staat, en dat als staatsburger officieel ook waren. Omdat zij op korte termijn weinig van hun regering verwachtten, hebben sommige voormalige grensarbeiders een advocaat in de arm genomen om hun recht te halen. Dat deden meer grensarbeiders, blijkens een aantal krantenartikelen waarin melding wordt gemaakt van rechtszaken die grenspendelaars bij het Europese Hof hadden aangespannen. ${ }^{95}$

92 Zie ook Sociale Verzekeringspositie van grensarbeiders 9-10; Commissie grensarbeiders, Rapport van de Commissie grensarbeiders, 42-43; zie ook Pennings, Heeft het werklandbeginsel zijn langste tijd gehad?.

93 Deze uitsluiting was gebaseerd op de gedachte dat er in het buitenland een loongerelateerde, op het gezinsinkomen afgestemde, oudedagsvoorziening werd opgebouwd. Vanwege het in Nederland geldende kostwinnersprincipe werd daarom lange tijd 2 procent van de Nederlandse AOW van hun partners ingehouden voor ieder jaar dat de grensarbeider in Duitsland had gewerkt (Commissie Grensarbeiders, Rapport Commissie grensarbeiders, 37-38).

94 Halverwege de jaren 1980 is de AOW-korting in verband met Europese regelgeving stopgezet. Aan het einde van de jaren 1990 werd bovendien besloten dat de misgelopen AOW-uitkering met terugwerkende kracht diende te worden uitbetaald aan niet-verdienende echtgenotes/n van grensarbeiders die met ingang van de jaren 1980 in Duitsland hadden gewerkt (Commissie grensarbeiders, Rapport van de Commissie grensarbeiders, 36-38). In 2001 is besloten ook echtgenoten/s van grensarbeiders die tussen 1957 (het jaar dat de AOW werd ingevoerd) en 1980 in Duitsland werkten, te compenseren voor de misgelopen gelden (DDL, 11-12-2001; Weerepas, 'Grensoverschrijdende Arbeid in de Euregio', 98).

95 LD, 22-2-1995; Advocate Hesen namens de VEG in DDL, 5-8-2000. 
Het aflopen van de werkzaamheden in Duitsland betekende niet dat de voormalige grensarbeiders nooit meer in Duitsland kwamen. De ex-pendelaars maakten geen gebruik meer van de Duitse zorg, omdat dit niet langer werd vergoed, maar bleven de grens in andere sferen van het dagelijks leven wel oversteken. Zo bezochten zij Duitsland nog geregeld om te winkelen, te tanken of te recreëren. Vooral winkelen en tanken waren in hun tijd als grensarbeider gangbaarder geworden. Vanwege de lagere Duitse prijzen en een door de jaren heen ontwikkelde voorkeur voor bepaalde Duitse producten, zoals bier en brood, zetten voormalige grensarbeiders die dichtbij de grens woonden, deze activiteiten dikwijls voort. Verder keken en luisterden met name de oudere grensarbeiders en degenen die hun werkzaamheden in Duitsland recentelijk hadden beëindigd, nog naar de Duitse televisie en radio. In vergelijking met de periode voordat zij in Duitsland werkten, hadden deze media wel meer concurrentie en een andere functie gekregen. Met het oog op haar pensioen beschouwde Bep de Wever het Duitse journaal bijvoorbeeld als een belangrijke bron van informatie over het Duitse beleid op dat gebied. Ook op deze manieren werd de pendelrelatie met Duitsland dus deels in stand gehouden.

Wouter Slootman is de enige geïnterviewde grensarbeider die naar Duitsland is verhuisd. Hij deed dit pas enkele jaren na het aflopen van zijn betrekking in Duitsland en hij en zijn echtgenote bleven daarna allebei in Nederland werken, deden er meestal boodschappen en verwachtten hun kinderen in de toekomst naar een Nederlandse school te sturen. Ondanks hun verhuizing bleef hun dagelijks leven zich dus grotendeels aan de Nederlandse zijde van de grens afspelen. In dat opzicht weken zij niet af van de 'Nederduitsers' die Strüver beschrijft. ${ }^{96}$

In sociaal opzicht lijkt de grens na het beëindigen van de arbeidsrelatie met Duitsland weer aan belang te hebben gewonnen. Het contact met Duitse oud-collega's werd direct beëindigd of verwaterde met de jaren. De aangehouden contacten met voormalige Duitse collega's bleven vaak beperkt tot door de oud-werkgevers georganiseerde bijeenkomsten, zoals een jaarlijks terugkerende reünie van een grote metaalfabriek. Volgens René Veldman werden deze echter zelden door Nederlandse collega's bezocht, omdat zij 'niet meer met Duitsland in contact willen komen'.

Zoals reeds bleek uit de manieren waarop de grensarbeiders in vergelijkingen met Duitsers hun Nederlandse identiteit in de interviews benadrukten, reproduceerden zij de grens ook in symbolisch opzicht na het afsluiten van de werkzaamheden in Duitsland. Wanneer zij zich met de rest van Nederland vergeleken, wezen sommigen echter op Duitse invloeden die er door het werken in Duitsland in waren geslopen, waardoor de grens symbolisch gezien toch iets poreuzer lijkt te zijn geworden.

\section{SLOT}

In dit hoofdstuk stond de vraag centraal hoe grensarbeid en de grens zich in de ervaringen van geïnterviewde grenspendelaars tot elkaar verhouden. In het algemeen kan geconcludeerd worden dat grensarbeid onlosmakelijk was verbonden met de grens en onvermijdelijk samenging met het 'verleggen' van de grens. Afhankelijk van de temporele context en hun beroep, leeftijd en geslacht, nam de relatie tussen de grenspendel en de verschillende dimensies van 
de grens andere gedaanten aan in de trajecten die de grensarbeiders doorliepen. Gebleken is dat de grensarbeiders de grens weliswaar overschreden, maar zich er tegelijkertijd sterker mee geconfronteerd zagen, haar reproduceerden en haar betekenis ook konden veranderen. Dit varieerde historisch gezien, in de trajecten die de grensarbeiders doorliepen en tussen de verschillende groepen grensarbeiders, en was dikwijls paradoxaal. Dat laatste was op drie manieren het geval.

Voorafgaand aan het werken in Duitsland vormde de grens gewoonlijk een mentale drempel die werd overschreden op het moment dat de pendelaars door anderen werden gewezen op de mogelijkheid om in Duitsland te gaan werken. Personen uit informele sociale netwerken fungeerden als schakel naar de Duitse arbeidsmarkt. Een gebrek aan (passend) werk in de eigen begrensde woonomgeving en de mogelijkheid om aan de andere kant van de grens meer geld te verdienen, hebben veel grensarbeiders vervolgens over de streep getrokken. De grens als sociaal-economische scheidslijn was daarmee tevens een brug naar de Duitse arbeidsmarkt. In die zin was er sprake van de paradox van de grens zoals Knotter hem omschrijft. ${ }^{7}$

Zodra de grensarbeiders in Duitsland werkten, reisden zij op veranderende manieren naar hun werk. Mede door de afname van het aantal grensarbeiders maakte het massalere vervoer in busjes en touringcars in de jaren 1970 plaats voor kleinschaliger vervoer per auto. Door vrijwel uitsluitend met Nederlandse collega's naar het werk te reizen, bleven de grensarbeiders de grens in haar sociale betekenis gedurende de gehele periode bevestigen. Ook in haar fysieke hoedanigheid was de grens onvermijdelijk onderdeel van de reis naar het werk. Haar gedaanteverandering en het verdwijnen van de douanecontroles maakten dat de grensarbeiders zich daar, vooral sinds de jaren 1990, minder sterk van bewust waren. Toch ebde het besef van de grensovergang niet helemaal weg.

Doordat zij een ander land betraden, wisten de grensforensen gedurende de gehele onderzoeksperiode in eerste instantie niet goed wat hen in Duitsland te wachten stond en dat baarde hen zorgen. De achtergronden van hun onzekerheid verschilden in de tijd en per beroepsgroep, maar hadden veelal betrekking op hun vakbekwaamheid, hun beheersing van de Duitse taal en hun wettelijke en sociale positie. Juist doordat de grensarbeiders de grens overschreden, voelden zij zich er tegelijkertijd in toenemende mate mee geconfronteerd. Hier kan van een tweede paradox van de grens worden gesproken: juist het overschrijden van de grens maakte dat zij zich uitdrukkelijker deed gelden in hun dagelijks leven.

$\mathrm{Na}$ een beginperiode waarin zij zichzelf als fremdkörper in Duitsland zagen, maakten de grensarbeiders zich de Duitse taal, werkwijzen, regels en omgangsvormen steeds meer eigen. Naarmate zij ingewerkt raakten, nam hun onzekerheid af. Dat ging gepaard met gevoelens van vervreemding van de Nederlandse taal, werkwijzen, regels en mores, waardoor de grens als barrière naar Nederland aan betekenis won. Hierin zagen de grensarbeiders zich bij een eventuele terugkeer naar de Nederlandse arbeidsmarkt bevestigd. Daarnaast groeide het bewustzijn van de grens als institutionele scheidslijn, doordat de grenspendelaars met name in de jaren 1980 en 1990 zicht kregen op discrepanties tussen de Nederlandse en Duitse wet- en regelgeving. Nederlandse en Duitse praktijken en oriëntaties konden eveneens met elkaar vermengd raken. Doordat zij tegelijkertijd inburgerden in Duitsland, vervreemdden van Nederland en praktijken uit en oriëntaties op beide landen met elkaar verweefden, hadden de grens- 
arbeiders dikwijls het gevoel tussen wal en schip te vallen. $\mathrm{Zij}$ bevonden zich in een tussenpositie waardoor zij zowel in Nederland als in Duitsland een fremdkörper waren.

Dat wil niet zeggen dat de grensarbeiders in een identiteitscrisis raakten. Hoewel zij in zekere zin nader tot de Duitsers kwamen, doordat zij goed contact met hen onderhielden en aangaven als (Zuid-)Limburgers in tegenstelling tot 'de Hollanders' gelijkenissen met de Duitsers (of de 'Pruisen') te vertonen, karakteriseerden de grensarbeiders de Duitsers veelal aan de hand van nationale stereotypen. Op die manier en in hun gedrag op de werkvloer profileerden zij zichzelf duidelijk als Nederlanders. Afhankelijk van de context kon de territoriale identiteit van de grensarbeiders dus verschuiven en ertoe leiden dat zij zich ofwel tegen de Duitsers afzetten of op overeenkomsten met hen wezen. De articulatie van hun Nederlandse identiteit betekende niet noodzakelijkerwijs dat zij zich ook sociaal gezien van de Duitsers afzonderden. Verwijzingen naar de symbolische grens konden ook een gedeeld referentiekader bieden en haar dus als verbindingslijn doen fungeren. Hier kan een derde paradox van de grens worden onderscheiden: de referentie aan de grens als scheidslijn maakte haar tevens een verbindingslijn.

Het einde van het werken in Duitsland betekende niet dat de grenspendel en de grens geen rol van betekenis meer speelden in het dagelijks leven van de voormalige grensarbeiders. Hun denken, handelen en formele positie was dermate veranderd, dat zij de rest van hun leven een pendelrelatie met Duitsland bleven onderhouden. 


\section{Hoofdstuk 7 \\ Over de streep}

Dit boek opende met een verwijzing naar het Europese integratieproces. Dat vormt het decor waartegen onderzoek is verricht naar de ontwikkeling van de verhouding tussen grensarbeid en de grens die daarbij wordt overschreden. Grenzen zijn opgevat als meerdimensionale en dynamische constructies, die een stempel drukken op het dagelijks leven in grensgebieden, maar daar zelf ook door worden gevormd. ${ }^{1} \mathrm{Zij}$ dragen altijd een zekere dubbelzinnigheid in zich, omdat ze tegelijkertijd scheids- en verbindingslijnen zijn. Het dagelijks leven in grensgebieden wordt gekenmerkt door het samengaan van het grensoverstijgende en het begrensde. Grensforensen zijn te beschouwen als grensgevallen, die deze ambivalentie bij uitstek belichamen. Zij bevinden zich in een tussenpositie, doordat zij vrijwel dagelijks in twee landen vertoeven, waartussen zij heen en weer manoeuvreren. Zo verpersoonlijken ze de spanning tussen het grensoverschrijdende, en in die zin transnationale, en de grenzen van de natiestaat in politiek-materiële en sociaal-culturele zin.

Om recht te doen aan de ingewikkelde en veranderlijke relatie tussen grensarbeid en de grens, is in dit onderzoek ingezoomd op één pendelstroom die over een periode van ruim veertig jaar en op drie manieren is bestudeerd. Het betreft de casus van de grenspendel vanuit Zuid-Limburg naar Duitsland vanaf 1958 tot en met 2001. Allereerst is nagegaan hoeveel en welke grensbewoners er door de jaren heen in Duitsland werkten en hoe dit samenhing met arbeidsmarktontwikkelingen aan weerszijden van de grens. Behalve voor kwantitatieve aspecten van de grenspendel was er aandacht voor de betekenis die hij op regionaal en individueel niveau kreeg. Het tweede deel van het onderzoek betrof dan ook de beeldvorming rond de Duitslandpendel in de regionale publieke sfeer. Deze was verbonden met de heersende opvattingen over de verhouding tussen het betreffende grensgebied en de natiestaat, en daarmee met de betekenis van de grens op regionaal niveau. Ten derde is via de ervaringen van de grensarbeiders nagegaan hoe praktijken en percepties van grensoverschrijdende mobiliteit en de grens elkaar beïnvloedden.

In dit laatste hoofdstuk wordt teruggeblikt op de belangrijkste resultaten van de verschillende onderdelen en worden zij met elkaar in verband gebracht, om zodoende tot een gedifferentieerd beeld van de verhouding tussen grensarbeid vanuit Zuid-Limburg naar Duitsland en de Nederlands-Duitse grens te komen. Op die manier wordt tevens licht geworpen op de wijze waarop de betekenis van de grens in het dagelijks leven in Zuid-Limburg zich heeft ontwikkeld. Aansluitend wordt nagegaan hoe de onderzoeksresultaten zich verhouden tot de Europese visie op en maatregelen ten aanzien van grensgebieden en grensoverschrijdende arbeidsmobiliteit. 


\section{GRENSWERK}

\section{Van paradox naar parallel}

Eerder onderzoek naar de omvang en samenstelling van grensoverschrijdende pendelstromen en de achtergronden daarvan behelsde hoofdzakelijk korte termijn- of momentopnames. Hetzelfde geldt voor de meeste studies die zich specifiek op de grenspendel vanuit ZuidLimburg naar Duitsland richten. Door de kwantitatieve ontwikkeling van deze pendelstroom in dit onderzoek over een langere termijn te bestuderen, ontstond een dynamischer beeld. Daaruit bleek dat er zich in ruim veertig jaar tijd ingrijpende wijzigingen hebben voltrokken. De Nederlands-Duitse grens was daarbij in haar politiek-materiële, maar ook in haar sociaalculturele dimensie, steeds van vitale betekenis.

In de kwantitatieve ontwikkeling van de arbeidsstromen konden twee perioden worden onderscheiden. In de eerste periode, vanaf het einde van de jaren 1950 tot en met het einde van de jaren 1970, nam de Duitslandpendel relatief omvangrijke, maar fluctuerende vormen aan. Destijds bestonden er aanmerkelijke kwantitatieve verschillen tussen de arbeidsmarkten aan weerszijden van de grens. De arbeidsmarkt van Zuid-Limburg was in mineur, terwijl die in het aangrenzende Duitse gebied floreerde. Bovendien sloot de Duitse vraag naar laaggeschoolde handarbeiders in kwalitatief opzicht goed aan op het arbeidsaanbod in Zuid-Limburg. De gunstige omstandigheden aan Duitse zijde van de grens maakten het mogelijk zonder te verhuizen aan de onzekere arbeidsmarktsituatie in Zuid-Limburg te ontsnappen en een betrekkelijk goed inkomen te genereren. Juist doordat de arbeidsmarkten van elkaar gescheiden waren, raakten zij via de grenspendel enige tijd nauwer met elkaar verbonden. De rol van de grens was paradoxaal: enerzijds fungeerde zij als scheidslijn, maar anderzijds vormde zij precies daarom een verbindingslijn. ${ }^{2}$ Desalniettemin benutte het overgrote deel van de Zuid-Limburgse beroepsbevolking de mogelijkheden aan de overzijde van de grens niet. Ondanks de sterke push- en pull-factoren werd zij ervan weerhouden om (de mogelijkheid in overweging te nemen om) in Duitsland te gaan werken. De fluctuaties in de omvang van de pendelstroom hielden in deze periode gelijke tred met de ontwikkeling van de conjunctuur. Deze conjunctuurgevoeligheid is voor een groot deel terug te voeren op de vele Zuid-Limburgers die in de Duitse bouw werkten. De recessie van 1966 en 1967 had nog slechts een tijdelijke inkrimping van het aantal grensarbeiders tot gevolg, maar de oliecrisis in 1973 kondigde een drastische afname van de Duitslandpendel aan.

In de tweede periode, vanaf de jaren 1980 tot en met 2001, vertoonden de arbeidsmarktomstandigheden aan weerszijden van de grens in kwantitatief opzicht meer gelijkenis. Daarnaast brachten het deïndustrialiserings- en het tertiairiseringsproces veranderingen teweeg in de werkgelegenheidsstructuur. Onder deze condities bleef het aantal grensarbeiders redelijk constant, maar minimaal, zeker gezien het grote aandeel Duitse immigranten dat in Duitsland was blijven werken. Doordat de arbeidsmarkten aan Nederlandse en Duitse zijde van de grens een soortgelijke ontwikkeling doormaakten, verdween de aanleiding om de grens te overschrijden. Bovendien was de goede aansluiting tussen de vraag naar arbeidskrachten aan Duitse en het aanbod aan Nederlandse zijde van de grens grotendeels verleden tijd, en wonnen mede door de tertiairisering van de economie grensgebonden institutionele en sociaalculturele hindernissen voor de grenspendel aan belang.

2 Zie Knotter, 'Paradoxen van de grens', 161. 
In beide perioden bleek de grens van wezenlijk belang voor de ontwikkeling van de pendelstroom. Als politiek-materiële scheidslijn markeerde zij verschillen in sociaal-economisch beleid. Deze leidden in de jaren 1960 en 1970 tot ongelijke kwantitatieve ontwikkelingen, die de pendel stimuleerden. Onder de meer parallelle kwantitatieve en herstructurerende arbeidsmarktomstandigheden van de jaren 1980 en 1990 hadden grensgerelateerde institutionele verschillen doorgaans een belemmerende werking. Daarnaast zijn er aanwijzingen dat de grens in sociaal-culturele zin de pendel vooral in de weg stond. Dat geldt voor de hele periode vanaf het einde van de jaren 1950 tot en met 2001. Dat strookt met bevindingen van recente onderzoeken, maar lijkt dus al eerder te zijn opgegaan. Een deel van de Zuid-Limburgse bevolking werd er steeds van weerhouden om bij haar arbeidsmarktoriëntatie het vizier op Duitsland te richten. Toen de arbeidsmarktsituaties aan weerszijden van de grens bijzonder sterk van elkaar verschilden, gebeurde dat op grotere schaal dan toen er meer overeenkomsten bestonden.

Vanuit regionaal sociaal-economisch perspectief beschouwd was de grens dus van cruciale maar ambigue en veranderlijke betekenis voor de ontwikkeling van de grenspendel en daarmee ook voor het dagelijks leven in Zuid-Limburg. Een gebrek aan grensoverschrijdende integratie bleek niet alleen als obstakel, maar eveneens als stimulans voor grensoverschrijdende mobiliteit te kunnen fungeren. In dat laatste geval was zij tegelijkertijd kloof en brug.

\section{Van periferie tot centrum}

Uit de analyse van de berichtgeving in de Limburgse dagbladen bleek dat ook de regionale beeldvorming rond de Duitslandpendel in een kort tijdsbestek veranderde. Hoewel er gedurende de gehele periode werd gesproken van een 'pendelprobleem', konden in de definitie daarvan twee perioden worden onderscheiden. Er sprak veelal een normatief oordeel uit de wijze waarop 'de pendelproblematiek' werd gedefinieerd, dat door de jaren heen werd bijgesteld. Ongeacht de positieve betekenis die sinds de jaren 1950 in Europees verband aan grensoverschrijdende arbeidsmobiliteit wordt toegedicht en de ongunstige regionale arbeidsmarktsituatie die de Duitslandpendel ten dele in de hand werkte, werd hij tot in de tweede helft van de jaren 1970 afgekeurd. In de daaropvolgende decennia werd er daarentegen juist mee ingestemd. Tot de jaren 1990 manifesteerde zich dat alleen in de acceptatie van de grenspendel. Nadien werd hij tevens verwelkomd. De twee perioden in de beeldvorming vallen nagenoeg samen met de tijdvakken die er in de kwantitatieve ontwikkeling van de pendelstroom zijn onderscheiden. Er bestond daarbij steeds een discrepantie tussen de gewenste en de werkelijke omvang van de grenspendel. Nu kan gesteld worden dat hij een grotere bedreiging vormt wanneer hij grotere proporties aanneemt. Dat biedt evenwel geen afdoende verklaring voor de manier waarop hij werd beoordeeld.

In de periode tot het einde van de jaren 1970 bestond 'de pendelproblematiek' erin dat grensarbeid schadelijk zou zijn voor het persoonlijk leven van de grensforensen, de nationale economie en in het bijzonder de regionale arbeidsmarkt. Met name Nederlandse sociale partners, Limburgse autoriteiten, journalisten en uit Limburg afkomstige politici kwalificeerden de grenspendel daarom als ongewenst. Harmonisering van sociale en fiscale wet- en regelgeving werd als de manier gezien om de verschillen aan weerszijden van de grens uit te vlakken, waardoor het minder aantrekkelijk zou worden om over de grens te werken. De grens moest dus als het ware worden uitgewist om de grenspendel binnen de perken te houden. 
Sinds het einde van de jaren 1970 werd de Duitslandpendel positiever beoordeeld. Er werd niet langer gerept over schadelijke gevolgen voor de nationale economie en de regionale arbeidsmarkt. 'De pendelproblematiek' bestond er nu in dat de grensarbeiders financiële nadelen ondervonden van de afwijkende nationale systemen van wet- en regelgeving. Werken over de grens behoorde gelijk te staan aan werken in eigen land. Grenspendel moest niet langer worden voorkomen of beëindigd, maar diende juist te worden gefaciliteerd. Daarmee werden hij en de bijbehorende afhankelijkheid van het buurland geaccepteerd. Met ingang van de jaren 1990 werd aan deze probleemdefinitie toegevoegd dat de aanhoudende moeilijkheden grensoverschrijdende arbeidsmobiliteit belemmerden en op die manier de regionale ontwikkeling in de weg stonden. De gedachte was dat grensarbeid daaraan zou bijdragen en derhalve gestimuleerd moest worden. De grens werd nu als knellend ervaren. Dat was in de jaren 1960 en een groot deel van de jaren 1970 ondenkbaar. Anders dan in die decennia gold harmonisering van de nationale sociale en fiscale systemen nu als het middel om grenspendel te vergemakkelijken en te stimuleren. In tegenstelling tot de jaren 1960 en 1970 was de verwachting dus dat het uitvlakken van de grens op institutioneel gebied een grotere grenspendel in de hand zou werken.

Terwijl politiek-materiële aspecten van de grens centraal stonden in de beeldvorming rond de grenspendel, was de sociaal-culturele dimensie eveneens aanwezig. De aandacht ging hoofdzakelijk uit naar de economische ontwikkeling en institutionele discrepanties tussen beide zijden van de Nederlands-Duitse grens, maar in de eerste periode was er ook sprake van bezorgdheid over de invloed van de grenspendel op onder meer de persoonlijke ontwikkeling van de grenspendelaars. Belangrijker is dat de sociaal-culturele dimensie van de grens op impliciete wijze aanwezig was in de referentiekaders waarbinnen de grenspendel betekenis kreeg. De kanteling in de beeldvorming vloeide voort uit een veranderende conceptie van (Zuid-)Limburg als grensgebied. Het oordeel over de grenspendel was nauw verbonden met de spanning tussen het grensoverschrijdende en het begrensde dat erin besloten lag en waartussen steeds een balans moest worden gezocht. In de eerste periode sloeg deze door naar een nationaal begrensde visie op (Zuid-)Limburg als grensgebied. Het werd benaderd als perifere regio, die binnen de Nederlandse staat op eigen benen moest kunnen staan. Vanuit dit nationaal begrensde betekeniskader werd het controleverlies van de Nederlandse staat en de afhankelijkheid van Duitsland die de pendel in zich droeg, afgewezen. ${ }^{3}$ Vanaf het einde van de jaren 1970 speelden nieuwe partijen een belangrijke rol in de berichtgeving, en kenterde de beeldvorming geleidelijk aan in positieve richting. Zo waren de in 1978 opgerichte belangenorganisatie van de grensarbeiders (VEG) en, sinds het begin van de jaren 1990, ook Euregionale autoriteiten veelvuldig in de berichtgeving aan te treffen. Zij vertegenwoordigden echter een algemener vertoog rond de grenspendel, dat ook een ingang vond onder de gevestigde partijen, zoals de uit Limburg afkomstige politici, Limburgse autoriteiten en Nederlandse vakbonden. Het nationaal begrensde denkkader maakte langzaam plaats voor een 'ontgrensd' betekeniskader, waarbij Zuid-Limburg als deel van de Euregio Maas-Rijn (EMR) als centrale Europese regio werd benaderd. Het streven was niet langer de grens als barrière, maar als brug naar Duitsland te doen fungeren. De gedachte was dat zowel de grensar-

3 Er was dus wel aandacht voor de afhankelijkheid van Duitsland, wat typerend is voor de relatie tussen Nederland en Duitsland. Die belangstelling werd hier echter niet speciaal gewekt omdat het Duitsland betrof. Afhankelijkheid van het buitenland in het algemeen werd afgekeurd. 
beiders als Zuid-Limburg de vruchten konden plukken van het vrij verkeer van werknemers in Europa.

Hoewel de grenspendel in de jaren 1960 en 1970 niet werd toegejuicht, nam hij in deze periode relatief grote vormen aan. De negatieve publiciteit leek de Duitslandpendel niet terug te kunnen dringen. Klaarblijkelijk had zij in die zin weinig van doen met de praktijken van de grensbewoners. Dat gold evenzeer voor de periode daarna. Toen de grenspendel werd geaccepteerd en sinds de jaren 1990 zelfs als bijdrage aan de regionale ontwikkeling werd toegejuicht, bleef het aantal grensarbeiders minimaal. In dat opzicht bleef de grenspendel een ongrijpbaar fenomeen.

\section{Transformatie, confrontatie en continuatie}

Anders dan de kwantitatieve ontwikkeling van de grenspendel en de regionale beeldvorming daaromtrent, lieten de ervaringen van de grensarbeiders zich niet in afgebakende historische tijdvakken indelen. Bepaalde aspecten van de dagelijkse praktijk en perceptie van het werken in Duitsland waren in de onderzochte periode en in het traject dat de grensarbeiders doorliepen, aan verandering onderhevig. Andere, vooral facetten die verbonden waren met de sociaal-culturele dimensie van de grens, vertoonden daarentegen een grote mate van continuïteit. Behalve in de tijd trad er enige variatie op afhankelijk van het beroep, het geslacht en de leeftijd van de grensarbeiders.

In politiek-materiële zin onderging de grens een duidelijke transformatie. Haar karakter als institutionele en fysieke scheidslijn veranderde in de eerste plaats historisch gezien. Zo was er met ingang van 1970 geen vergunning meer nodig om over de grens te mogen werken en werd de fysieke grens in de jaren 1990 geopend. Toch bleef de grensovergang zichtbaar en daarmee aanwezig in de ervaringen van de grenspendelaars. Daarnaast won de grens als administratieve scheidslijn aan betekenis in het traject dat de grensarbeiders doorliepen. Zodra zij in Duitsland werkten, en dus buiten de nationale kaders traden, werden zij geconfronteerd met systeemverschillen. Discrepanties tussen de nationale wet- en regelgeving creëerden onzekerheid en konden nadelige financiële consequenties hebben. De grotere loonverschillen en de beperktere complexiteit van de Nederlandse en de Duitse welvaartsarrangementen in de jaren 1960 en 1970 kunnen verklaren waarom dit volgens grensarbeiders in de eerste decennia minder sterk speelde dan in de jaren 1980 en 1990 . Voorts gingen in de laatste twee decennia verschillende grensarbeiders met pensioen, wat veel problemen met zich mee kon brengen. Terwijl de grensforensen de grens overschreden, ging zij in institutioneel opzicht, zowel historisch als in het traject dat zij doorliepen, dus een grotere rol spelen in hun dagelijks leven. Ook nadat zij hun werkzaamheden in Duitsland hadden beëindigd, kon zij zo als een rode draad door hun leven blijven lopen. In dat opzicht stuitte de 'ontgrenzing' van de arbeidsmarkt dus op duidelijke grenzen en hield de pendelrelatie met Duitsland in zekere zin stand.

De sociaal-culturele dimensie van de grens bleek een grotere bestendigheid te kennen, zowel historisch gezien als in de trajecten die de grensarbeiders doorliepen. Gedurende de gehele onderzoeksperiode bestond er voorafgaand aan het pendelen een mentale drempel ten opzichte van de Duitse arbeidsmarkt. Informatievoorziening via Zuid-Limburgse sociale netwerken was doorgaans essentieel om deze te overschrijden. Nadat de knoop was doorgehakt om in Duitsland te gaan werken, hielden reserves en onzekerheden stand. De grens markeer- 
de in eerste instantie vooral een overgang naar het onbekende en het andere. Na verloop van tijd vervaagde dit doordat de grensarbeiders meer ingeburgerd raakten in Duitsland. Dat ging echter samen met gevoelens van vervreemding van Nederland, waardoor de barrièrewerking van de grens als het ware omdraaide en een eventuele terugkeer naar de Nederlandse arbeidsmarkt volgens grensarbeiders werd bemoeilijkt. In deze gelijktijdige gedeeltelijke inburgering in Duitsland en vervreemding van Nederland komt de intermediaire positie van de grensarbeiders pregnant tot uitdrukking. Zij voelden zich zowel aan de Duitse als Nederlandse zijde van de grens fremdkörper. Hun tussenpositie uitte zich buitendien in een ambigue identiteit. Ten opzichte van de rest van Nederland profileerden zij zich als (Zuid-)Limburgers. Daarbij wezen zij, mede op basis van hun ervaringen in Duitsland, op overeenkomsten met de Duitsers. Desondanks gaf de identificatie met Nederland hun ervaringen in Duitsland in grote mate vorm. In hun beschrijvingen van en gedrag ten opzichte van de Duitsers distantieerden de pendelaars zich duidelijk van hen en profileerden zij zich als Nederlanders. De nadruk op de grens als symbolische scheidslijn hoefde de sociale afstand tot Duitse collega's echter niet noodzakelijkerwijs te vergroten. De verschillende nationaliteiten boden de grensarbeiders en hun Duitse collega's een gezamenlijk referentiekader, waardoor de grens tegelijkertijd als scheiding en als schakel kon fungeren. ${ }^{4}$

De betekenis van de grens maakte dus een gedeeltelijke transformatie door doordat de grensarbeiders haar op de arbeidsmarkt overschreden. In het algemeen kan gesteld worden dat de grens op verschillende manieren een paradoxale betekenis had in relatie tot de ervaringen met het werken in Duitsland. De grensarbeiders trokken de grens in eerste instantie over vanwege de verschillen die zij markeerde. Dat is de eerste manier waarop er sprake was van een paradox van de grens. Ook bleek grensoverschrijdende mobiliteit niet automatisch samen te gaan met een afnemend belang van de grens. De grensarbeiders bevonden zich in een ingewikkelde positie waarin zij steeds moesten schipperen tussen hun grensoverschrijdende activiteiten en oriëntaties en hun nationale gebondenheid. Daarbij verloor de grens deels aan belang, maar werd zij tegelijkertijd op bepaalde gebieden gereproduceerd en ging ze zelfs een grotere rol spelen dan zij voorafgaand aan de grensoverschrijding had gedaan. Hier kan een tweede paradox van de grens worden onderscheiden, namelijk dat grensoverschrijding tot een intensievere grenservaring kan leiden. Hoewel de grens als scheidslijn aan betekenis leek te hebben ingeboet op het moment dat de grensbewoners haar in verband met werk overschreden, trok zij sindsdien juist een duidelijker spoor door hun dagelijks leven. Dat geldt voor de grens in politiek-materiële zin, doordat de grensarbeiders met de grote verschillen in wet- en regelgeving werden geconfronteerd. Maar het gaat ook op voor de sociaal-culturele dimensie van de grens, omdat zij hun ervaringen in Duitsland vanuit een nationaal referentiekader interpreteerden. Bovendien profileerden zij zich tegenover de Duitsers en Duitsland primair als Nederlanders. Opmerkelijk is dat de pendelaars de grens in institutionele zin ter discussie stelden, terwijl zij haar in sociaal-culturele zin veelal reproduceerden. Bij de articulatie van de Nederlandse identiteit is een derde paradox te onderscheiden, namelijk dat dit niet noodzakelijk leidde tot het afsluiten van de grens in sociale zin. Juist het accentueren van herkenbare stereotypen maakte het mogelijk contact te leggen met de Duitsers. Concluderend kan gesteld worden dat de grens in beide dimensies en op verschillende manieren dus tegelijkertijd de hoedanigheid van scheidslijn en verbindingslijn kon aannemen. 
De ervaringen van de grensarbeiders zelf bieden een belangrijke nuancering van het beeld dat er vanuit regionaal sociaal-economische oogpunt kan ontstaan van de grensarbeiders die min of meer mechanisch reageren op sociaal-economische push- en pullfactoren. In dat deel van het onderzoek bleek al dat de rol van de grens op de arbeidsmarkt niet was uitgespeeld. De persoonlijke verhalen van de grensarbeiders bieden meer zicht op de achtergronden daarvan. Zo komt ook de meerdimensionaliteit van de grens beter tot haar recht. Indien grensarbeid primair vanuit een regionale sociaal-economische invalshoek wordt bestudeerd, ligt de nadruk op de politiek-materiële dimensie van de grens. De ervaringen van de grensarbeiders laten zien hoe de totstandkoming van grensarbeid, net als de praktijk en de betekenis ervan, niet los te zien is van haar sociaal-culturele dimensie.

Verder strookte de eerder beschreven beeldvorming in het regionale publieke domein niet altijd met de beleving van de grensarbeiders. Het regionale vertoog van de grensarbeiders als pioniers van Europese integratie en slachtoffers van het achterblijven daarvan op sociaal en fiscaal gebied verwoordden zij ook in de interviews. Grensarbeiders die in de jaren 1960 en 1970 in Duitsland waren gaan werken, waren daarentegen buitengewoon ontstemd wanneer zij met de negatieve beeldvorming rond de grenspendel in de jaren 196o en 1970 werden geconfronteerd. Zij beschouwden zichzelf niet als disloyaal ten opzichte van Nederland en Zuid-Limburg, maar juist als verantwoordelijke burgers die met het werken in Duitsland bewezen de Nederlandse gemeenschap niet tot last te willen zijn. Met hun identificatie met Nederland ten opzichte van Duitsland, zetten zij hun blijvende verbondenheid met de Nederlandse staat verder kracht bij.

Grensarbeid en grenzen zijn meerdimensionale, ambivalente en veranderlijke verschijnselen. Door hen op een gedifferentieerde en dynamische wijze te benaderen kan worden voorkomen dat er een te beperkt of vertekend beeld ontstaat. Dat geldt niet alleen voor de wetenschappelijke bestudering van grensarbeid en grenzen, maar ook voor de manier waarop er in de praktijk mee wordt omgegaan.

\section{EUROVISIE EN REGIONALE PRAKTIJK}

In het 'Europa zonder grenzen' wordt zowel veel belang gehecht aan grensoverschrijdende arbeidsmobiliteit als aan grensoverschrijdende integratie in grensgebieden. Grensarbeid verenigt beide ambities in zich. In Zuid-Limburg wordt op beide aspiraties ingespeeld, zoals onder meer blijkt uit de participatie in de EMR en in het kader daarvan in Eures. In de jaren 1990 kwam dit bovendien naar voren in de berichtgeving rond de grenspendel in de regionale pers. Onlangs manifesteerde dit grensoverschrijdend regionalisme zich nog in het rapport 'De toekomst van Limburg ligt over de grens', dat een commissie onder leiding van de voorzitter van MKB-Nederland, Hermans, in opdracht van de provincie opstelde. De kern van de nota is dat Limburg, en dan met name het zuidelijke deel van de provincie, veel nadelen ondervindt van obstakels voor grensoverschrijdende mobiliteit, interactie en samenwerking. De commissie concludeert dat 'Zuid-Limburg [...] zijn ontwikkelingsmogelijkheden steeds meer [moet] zien in interdependentie met de omliggende grensregio's en vooral de Euregio Maas-Rijn' en dat er maatregelen nodig zijn om daar beter op te kunnen inspelen. ${ }^{5}$ Daarbij attendeert zij op

5 Provincie Limburg, De toekomst van Limburg ligt over de grens, 39. De commissie pleit voor innovatieve vormen van samenwerking en stelt voor de EMR in de toekomst eventueel te laten beheren door een zogenaamde Europese Groepering voor Territoriale Samenwerking (EGTS), waardoor de EMR als zelfstandige Europese actor zou kunnen optreden (Ibidem, 56-6o). 
historische grensoverstijgende banden en een 'grensoverschrijdende mentaliteit'. Zij presenteert het gebied als kweekvijver van Europese integratie en mogelijke 'bruggenbouwer' tussen lidstaten bij uitstek. ${ }^{6}$ Een grensoverschrijdende arbeidsmarkt geldt als een van de randvoorwaarden om te kunnen profiteren van het in de 'Europese regio' Zuid-Limburg aanwezige potentieel. Deze grenzeloze arbeidsmarkt zou haar beslag moeten krijgen in een grotere grenspendel. Volgens de opstellers van het rapport staan grensgebonden hindernissen, zoals verschillen in wet- en regelgeving en een gebrek aan informatie, de totstandkoming daarvan echter in de weg. Het aanpakken van deze knelpunten is volgens hen noodzakelijk om de pendel te vergroten en daarmee de regionale ontwikkeling te bevorderen. ${ }^{7}$

Europese maatregelen op dit gebied blijken tot dusver evenwel weinig effect te sorteren. Ondanks alle inzet en aanmoediging is het aantal Europese grensarbeiders de afgelopen decennia minimaal gebleven. In Zuid-Limburg is het aantal Duitslandgangers zelfs sterk afgenomen ten opzichte van het begin van de jaren $1970 .{ }^{8}$ Het is dus maar de vraag hoe open de 'open' grenzen in Europa daadwerkelijk zijn. Beleid gericht op het opheffen van institutionele discrepanties en het intensiveren van de informatievoorziening kan een deel van de obstakels wegnemen. Toch lijkt dit niet de aangewezen weg om de grensoverschrijdende arbeidsmobiliteit substantieel te doen groeien. ${ }^{9}$

De uitblijvende mobiliteit vormde voor de Europese Commissie aanleiding om 2006 uit te roepen tot 'het jaar van de mobiliteit van werknemers'. Europees Commissaris Špidla van Werkgelegenheid, Sociale Zaken en Gelijke Kansen stelde in dit verband dat werknemers ervan overtuigd moesten raken dat 'the benefits of moving to another job or another country outweigh the costs'.$^{10} \mathrm{Hij}$ ging ervan uit dat bij een betere informatievoorziening meer Europeanen op basis van een kosten-batenafweging zouden kiezen voor werken over grenzen. Op de website die naar aanleiding van dit Europese themajaar is ontwikkeld, worden behalve de commissaris tevens Europese burgers aangehaald die over grenzen werk(t)en. Zij gaven aan op institutioneel vlak nog wel wat problemen te hebben ondervonden, maar wezen vooral op hun goede ervaringen, de positieve invloed die het op hun verdere carrière heeft gehad, de culturele verrijking die het met zich meebracht, en de bijdrage die het leverde aan hun identificatie met 'Europa'."

De gedachte van Commissaris Spidla dat de Europeanen alleen maar overtuigd hoeven te raken van de voordelen van grensoverschrijdende arbeidsmobiliteit, is te eenvoudig. Op basis van deze case-study over de Duitslandpendel vanuit Zuid-Limburg is het natuurlijk niet mogelijk om met een pasklare oplossing voor de bestaande knelpunten op Europees niveau te komen. Wel maakt zij duidelijk dat grensarbeid en grenzen complexere verschijnselen zijn dan in de beleidsvorming dikwijls lijkt te worden aangenomen. Om te beginnen hebben grenzen naast een politiek-materiële een sociaal-culturele dimensie. Deze zijn onlosmakelijk met elkaar en met grensarbeid verbonden. Zo lang Europese, nationale en (Eu)regionale auto-

6 Ibidem, 65, 104 .

7 Ibidem, 65, 67-73, 77. Onder het kopje 'Arbeidsmarkt en economie' verwijst zij vooral naar grensmigranten die in hun land van herkomst blijven werken. Hierbij gaat het niet echter zozeer om arbeids- als wel om verhuismobiliteit (Ibidem, 67).

8 Ook de pendel naar Duitsland en met België is over het geheel genomen niet bijzonder sterk gegroeid. Het aantal in Duitsland woonachtige grensarbeiders in Zuid-Limburg is wel betrekkelijk sterk gestegen, maar klein gebleven (zie CBS, Sociale Maandstatistiek 1975-1984; Idem, Sociaal-Economische Maandstatistiek 1984-2000).

9 Zie ook De Gijsel en Janssen, 'Grensoverschrijdende samenwerking vanuit economisch perspectief', 64; Strüver, 'Significant Insignificance', 22-23, 32-33.

$10 \mathrm{http}: / /$ ec.europa.eu/employment_social/workersmobility_2006/index.cfm?id_page=1.

11 http://ec.europa.eu/employment_social/workersmobility_2006/index.cfm?id_page=140. 


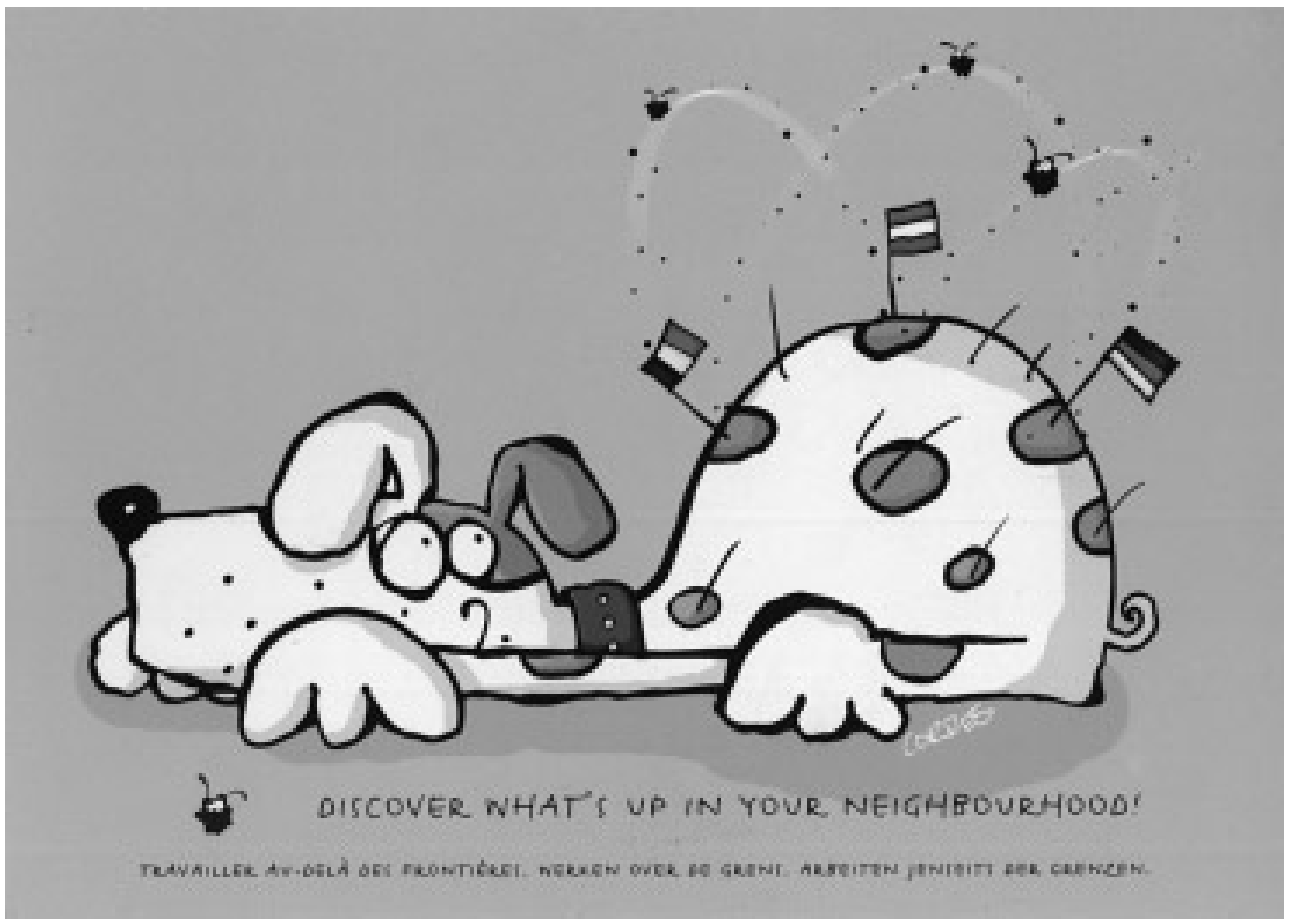

Promotiemateriaal Eures Maas-Rijn. Bron: http://www.eures.info/ecards/index.php?lang=nl (ontwerp: Birte Cordes).

riteiten in hoofdzaak initiatieven nemen gericht op de politiek-materiële aspecten van grenzen, blijven zij in hun sociaal-culturele dimensie intact.

Dat neemt uiteraard niet weg dat maatregelen gericht op het aanpakken van institutionele problemen en informatievoorziening wel bijzonder waardevol kunnen zijn voor degenen die de stap over de grens al hebben gezet. De geïnterviewde grensarbeiders beschouwden zichzelf bovendien vaak als echte Europeanen. Door de institutionele discrepanties waar zij tegenaan liepen, waren ze evenwel teleurgesteld in Europa's prestaties. Dat komt het draagvlak voor Europa niet ten goede. Voor sommigen waren de financiële nadelen en onzekerheid die de ingewikkelde juridische positie als grensarbeider met zich meebracht, reden om een punt te (willen) zetten achter hun werkzaamheden over de grens. Ook daarna konden deze echter nog een streep door de rekening blijven trekken.

Maar wanneer uitsluitend institutionele obstakels en informatieproblemen worden weggenomen, wordt grensarbeid alleen gefaciliteerd en zullen immobiele grensbewoners niet op grote schaal in beweging komen. Voordat zij überhaupt tot een besluitvormingsproces komen waarin zij het werken over grenzen overwegen, zorgt een nationale habitus er vaak voor dat ze eerst een threshold of indifference moeten overschrijden. ${ }^{22}$ Dat gold eveneens voor de ZuidLimburgse grensarbeiders. In die zin kan gesteld worden dat de grensoverschrijdende mentaliteit in Zuid-Limburg een mythe is.

12 Van der Velde en Van Houtum, 'De-politicizing labour market indifference', 47-50; Van Houtum en Van der Velde, 'The power of labour market immobility', 102-105. 
Voorts heeft deze studie aangetoond dat de ongelijkheden die grenzen markeren grensoverschrijdende arbeidsmobiliteit niet altijd hoeven af te remmen. Zo kunnen afwijkende arbeidsmarktontwikkelingen aan weerszijden van een grens het juist in de hand werken. De grens als scheidslijn kan dus ook kansen bieden. ${ }^{13}$ Nochtans lijkt er in de beleidsvorming meestal van uit te worden gegaan dat zij uitsluitend beperkingen en belemmeringen met zich meebrengt. Indien de betrokken autoriteiten zich blijven richten op convergentie kan dit er onbedoeld toe leiden dat de aantrekkelijkheid van het werken over de grens helemaal verdwijnt. Zelfs harmonisering van wet- en regelgeving om grensarbeid te stimuleren kan dan bijvoorbeeld een averechts effect hebben, doordat zij de prikkels om over de grens te werken wegneemt. ${ }^{14}$ In dit verband is het tevens van belang stil te staan bij de vraag of de grenspendel doel of middel is. Dat heeft te maken met de verwachte consequenties van grensoverschrijdende arbeidsmobiliteit. Er dient gewaakt te worden voor een 'morele geografie' met de norm dat 'borders should be overcome' in de 'grenzeloze' Europese ruimte. Die zou ervoor kunnen zorgen dat het uitblijven van grenspendel moreel wordt afgekeurd. ${ }^{15}$

Uit dit onderzoek is gebleken dat de Europese visie op grensarbeid en grensgebieden niet automatisch een geschikte voedingsbodem vindt in deze gebieden. In Zuid-Limburg kon zij pas relatief laat wortel schieten. Terwijl het streven naar een vrij verkeer van werknemers reeds in het Verdrag van Rome werd verankerd en er in de jaren 1960 en 1970 al diverse maatregelen werden genomen om dit te garanderen dan wel te faciliteren, werd er in Zuid-Limburgse publieke sfeer afwijzend gereageerd op de omvangrijke pendelstroom naar Duitsland. Pas aan het einde van de jaren $1970 \mathrm{kwam}$ daar verandering in. Tot die tijd bestond er een te sterke binding met de nationale staat, en werd de grenspendel vanuit een begrensd betekeniskader als schadelijk beoordeeld. In de jaren 1960 en 1970 vertoonden dus ook de opiniemakers weinig sporen van een grensoverschrijdende mentaliteit.

Tot slot hielden de grensarbeiders de grens deels zelf in stand. Zij gaven weliswaar aan dat ze zich de conventies van de overzijde van de grens na verloop van tijd eigen maakten, maar reproduceerden haar grotendeels in haar sociaal-culturele dimensie. Ook in dat opzicht betekende grensoverschrijdende mobiliteit en interactie niet dat de grens geen rol van betekenis meer speelde in hun praktijken en percepties. De verwachtingen van sociale en vooral culturele integratie door grensoverschrijdende arbeidsmobiliteit dienen dan ook niet te hooggespannen te zijn.

13 Vgl. Baud en Van Schendel, 'Toward a Comparative History of Borderlands', 230-231; O'Dowd, 'The Changing Significance of European Borders', 24-26.

14 Vgl. Schack, 'Cross-border commuting and integration'; zie ook Werner, 'Beschäftigung von Grenzarbeitnehmern', 32; Boutillier et al., Frontaliers du Nord, 210-211.

15 Zie Van Houtum die waarschuwt voor een 'morele geografie' en een 'cross-border doctrine' die de 'cross-border cooperation'-benadering in de grensstudies volgens hem kenmerkt ('An Overview of Geographical Approaches', 63-65 (cursivering in origineel)). 


\section{Appendix A \\ Bronnenkritiek statistiek}

Om de ontwikkeling van de omvang en samenstelling van de pendelstroom en de wijze waarop hij zich verhield tot arbeidsmarktontwikkelingen aan weerszijden van de grens, in kaart te brengen zijn verschillende bronnen gebruikt. Deze worden nu achtereenvolgens beschreven, waarbij tevens hun bruikbaarheid en betrouwbaarheid wordt geëvalueerd.

\section{Districtsbureau voor de Arbeidsvoorziening Limburg}

Het Districtsbureau voor de Arbeidsvoorziening in Limburg (DBA) publiceerde vanaf 1954 tot en met 1986 jaarlijks de Arbeidsmarktbeschrijuing voor de provincie Limburg. In deze verslagen werden over de jaren 1959 tot en met 1985 ook cijfers gepubliceerd over het aantal grensarbeiders van en naar Duitsland en België. Het DBA geeft aan dat de cijfers over het aantal grensarbeiders grotendeels zijn gebaseerd op schattingen. Tot 1974 zou het deze ten dele baseren op het aantal verstrekte arbeidsvergunningen. Bovendien zou het DBA een schatting van het aantal illegale pendelaars en personen die tijdelijk voor een Nederlandse firma in Duitsland werkten meenemen. In 1970 is het werkvergunningsysteem als gevolg van Verordening 1612/68 van de EEG afgeschaft. Sindsdien zijn er gegevens beschikbaar over het aantal ziekenfondsverzekerden in Duitsland. ${ }^{1}$ In een krantenartikel uit 1973 werd erop gewezen dat de cijfers van het DBA als de meest betrouwbare moesten worden beschouwd, omdat het DBA bij zijn berekeningen een combinatie maakte van de gegevens van het CBS, de Duitse 'arbeidscentrales', de gewestelijke arbeidsbureaus en de Nederlandse ziekenfondsen. ${ }^{2}$ In een artikel uit 1971 stelde een consulent van de Arbeidsvoorziening in Maastricht dat er volgens hem maximaal 300 Limburgse grensarbeiders aan de telling ontsnapten. De Duitse Krankenkassen (waar de ziekenfondsverzekerde grensarbeiders zich moesten aanmelden zodra ze in Duitsland werkten) spraken van maximaal 600 illegale pendelaars. ${ }^{3}$ Vanaf 1977 vermeldt het DBA de cijfers van het Centraal Bureau voor de Statistiek als bron. Toch wijken zijn cijfers daar nog enigszins van af (vooral in het jaar 1980). ${ }^{4}$

In 1959 waren er uitsluitend gegevens over de mannelijke grensarbeiders beschikbaar. Vanaf 1960 werden er ook cijfers gepubliceerd over het aantal vrouwen dat in Duitsland werkte. Vanaf 1959 tot en met 1962 en vanaf 1983 tot en met 1985 werden de gegevens uitgesplitst naar arbeidsmarktgewest, en van 1963 tot en met 1982 naar arbeidsmarktrayon, waar de grensarbeiders woonachtig waren. De indeling van deze ruimtelijke eenheden is op een aantal momenten gewijzigd (zie tabel A1).

\footnotetext{
Zie Vreuls, Grensoverschrijdende pendel, 26; Idem, 'Grenzüberschreitende Pendlerwanderungen', 12.

LD, $11-7-1973$.

3 LD, 18-5-1971.

4 DBA, Arbeidsmarktbeschrijuing 1977, 64; volgens Vreuls zou het DBA de CBS-cijfers vanaf dat jaar echter niet meer bewerken (Vreuls,'Grenzüberschreitende Pendlerwanderungen', 12).
} 
Behalve naar geslacht en woongebied zijn de cijfers over de jaren 1959 tot en met 1974 ook uitgesplitst naar de bedrijfstak waar de grensarbeiders werkten. Deze cijfers zijn met ingang van 1975 niet meer gepubliceerd. Het DBA maakte verder geen uitsplitsing naar de gebieden waar de grensarbeiders in Duitsland werkten, noch naar hun leeftijd. Verder maakte het DBA in het tekstgedeelte van de arbeidsmarktbeschrijvingen wel nog een uitvoerige analyse van de grenspendel.

Voor de berekening van het totale aantal Zuid-Limburgse grensarbeiders zijn de cijfers van de rayons en/of gewesten Vaals, Heerlen, Kerkrade, Brunssum, Valkenburg, Maastricht, Sittard, Echt en Roermond bij elkaar opgeteld. Probleem daarbij is dat ook gemeenten ten westen van de Maas deel uitmaken van het gewest of rayon Roermond, terwijl deze buiten het onderzoeksgebied vallen. Gezien de grotere afstand tot Duitsland en de mogelijke barrièrewerking van de Maas, kan er echter van uit worden gegaan dat de meeste grensarbeiders uit het gewest of rayon Roermond in het gebied ten oosten van de Maas woonden.

Over de periode vanaf 1959 tot en met 1975 publiceerde het DBA verder cijfers over de binnenlandse pendel in Limburg. Deze werden, net als de grenspendel, vanaf 1959 (in dat jaar alleen cijfers over mannen) tot en met 1962 ingedeeld naar arbeidsmarktgewest en vanaf 1963 tot en met 1975 naar arbeidsmarktrayon. Tevens stonden er in de arbeidsmarktbeschrijvingen meer algemene arbeidsmarktgegevens vermeld zoals de beroepsbevolking en de arbeidsreserve of (vanaf 1977) werkloosheid.

\section{Centraal Bureau voor de Statistiek}

Het Centraal Bureau voor de Statistiek in Nederland (CBS) publiceerde vanaf 1970 tot en met 1983 cijfers over grensarbeid van en naar Duitsland en België in de Sociale Maandstatistiek en sinds 1984 in haar opvolger de Sociaal-economische Maandstatistiek. Voor het jaar 2001 zijn cijfers van de website van het CBS http://statline.cbs.nl gebruikt. Het aantal grensarbeiders werd vanaf 1970 tot en met 1978 per 1 juni, vanaf 1979 tot en met 1982 per 1 april, en met ingang van 1983 op 31 maart gemeten.

Het CBS hanteert de volgende definitie van grensarbeiders: werknemers die op het grondgebied van het ene land wonen en in het andere land werken, zelfs wanneer zij niet dagelijks naar hun woonplaats terugkeren en ongeacht of zij al dan niet in het grensgebied wonen. ${ }^{5}$ Het gebruikte daartoe gedurende de gehele onderzoeksperiode cijfers uit de registratie van grensarbeiders bij de ziekenfondsen. Een aantal groepen blijft daardoor buiten beschouwing.

Op de eerste plaats sluit het CBS zo grensarbeiders uit die tijdelijk voor een werkgever (zoals koppelbazen of uitzendbureaus) uit het woonland in het andere land werken. ${ }^{6}$ Daarnaast worden personen met hogere inkomens en ambtenaren niet in de tellingen meegenomen, omdat zij gewoonlijk een particuliere verzekering hadden. Het was gedurende de gehele onderzoeksperiode echter moeilijk, zo niet onmogelijk, om in de publieke sector van een ander land te gaan werken. ${ }^{7}$ Volgens sommige auteurs zou het aantal grensarbeiders met 25 tot 
100 procent toenemen als deze personen wel werden meegeteld. ${ }^{8}$ Dit is waarschijnlijk vooral van toepassing op de situatie in de jaren 1990, omdat in deze periode het aantal uitzendkrachten en het aantal personen in de dienstverlening (waaronder de overheid) toenamen. Van de andere kant waren er in het begin van de jaren 1970 veel grensarbeiders via Nederlandse koppelbazen werkzaam in Duitsland. Deze waren echter dikwijls in Duitsland gevestigd, waardoor hun werknemers wel in de tellingen werden meegenomen. Maar aangezien ettelijke koppelbazen hun werknemers illegaal tewerk zouden stellen, zouden zij alsnog aan de registratie ontsnappen. Het verschil tussen de cijfers van het CBS en het DBA tot 1977 kan het gevolg zijn van het feit dat het DBA een schatting van de illegale en tijdelijk door Nederlandse werkgevers tewerkgestelde grensarbeiders meenam. Tenslotte stelden Van Camp et al. dat het CBS uitsluitend personen met een Nederlandse nationaliteit telde. ${ }^{9}$ Het CBS wijst er in haar Sociaal-Economische Maandstatistiek echter op dat vanaf 1970 iedereen met een ziekenfondsverzekering die vanuit Nederland in Duitsland werkt, is meegeteld. Dit betreft ook de geïmmigreerde Duitsers. ${ }^{10}$

Het CBS splitst de cijfers uit naar geslacht en woongebied. Daarbij hanteerde het door de jaren heen verschillende gebiedsindelingen. Vanaf 1970 tot en met 1980 publiceerde het cijfers naar het arbeidsmarktrayon waarin de grensarbeiders woonden. Met ingang van 1981 tot en met 1986 vermeldde het cijfers met betrekking tot arbeidsmarktgewesten in Nederland. Vanaf 1987 tot ten met 2001 publiceert het cijfers uitgesplitst naar COROP-gebied (voor de indeling in rayons, gewesten en COROP-gebieden: zie tabel A1). Overigens vermeldde het CBS tot en met 1986 uitsluitend de rayons en gewesten van waaruit in groten getale in Duitsland werd gewerkt. De totalen voor Zuid-Limburg tot en met 1986 zijn berekend door de totalen van de vermelde rayons/gewesten bij elkaar op te tellen. De gebruikte cijfers geven dan ook een ondergrens weer van het aantal grensarbeiders dat vanuit Zuid-Limburg in Duitsland werkte. ${ }^{11}$ Ook dit verklaart het verschil tussen de cijfers van het DBA en de berekende cijfers van het CBS.

Daarnaast vermeldde het CBS tot en met 2000 hoeveel grensarbeiders er per woongebied in de verschillende Duitse arbeidsmarktrayons werkten. Ook publiceerde het CBS cijfers over de verdeling naar leeftijdsgroep. Deze laatste gegevens zijn echter alleen op nationaal niveau beschikbaar. Dat geldt tevens voor cijfers over de verdeling van de grensarbeiders naar bedrijfsklasse, die slechts tot en met 1980 werden vermeld.

\section{Economisch Technologisch Instituut Limburg}

Om zicht te krijgen op de arbeidsmarktsituatie en de binnenlandse pendel in Zuid-Limburg vanaf de jaren 1980 is gebruik gemaakt van de jaarlijkse Limburgse Sociaal-Economische Verkenningen (LSEV) van het Economisch Technologisch Instituut Limburg (ETIL). Deze zijn verschenen vanaf 1980 tot en met 1999. Het ETIL gebruikte daarin cijfers van instanties als het CBS, maar ook het Centraal Planbureau. Daarnaast maakte het ETIL zelf ramingen. In de LSEV ver-

8 Van Dijk, en Zanen, 'Grensoverschrijdende samenwerking' 71; Janssen, 'Borders and labour-market integration', 52-53.

9 Van Camp et al., Naar de arbeidsmarkt zonder grenzen, 89, 92.

10 Zie bijvoorbeeld Sociaal-economische Maandstatistiek 1985/12, 16. Bovendien ontkende het CBS dit in een e-mailcorrespondentie d.d. 27 februari 2007.

11 De uitkomsten van het optellen van het aantal grensarbeiders in de vermelde rayons of gewesten in Zuid- en Midden-Limburg wijken licht af van het totaal aantal grensarbeiders uit Limburg minus het aantal grensarbeiders uit de vermelde rayons of gewesten in Noord-Limburg (zoals toegepast in Derks in Pendel 1973-1979). Afhankelijk van welke methode wordt gebruikt ligt het keerpunt dat in hoofdstuk 3 wordt beschreven in 1980 respectievelijk 1981. 
schenen cijfers over de beroepsbevolking, werkloosheid, maar ook pendelsaldi met Duitsland, België en de rest van Nederland. ${ }^{12}$ Met ingang van 2000 publiceert het ETIL de LSEV onder de titel 'Limburg in Beeld'.

Vanaf 1989 tot en met 1995 besteedde het ETIL in de LSEV uitgebreid aandacht aan de arbeidsmarktontwikkelingen in de aangrenzende Duitse en Belgische gebieden. ${ }^{13}$ Ten behoeve van de vergelijkbaarheid van de gegevens harmoniseerde het cijfers uit verschillende bronnen, zoals het CBS en het Landesamt für Datenverarbeitung und Statistik Nordrhein-Westfalen (LDSNRW) en EUROSTAT. Nadeel is dat het ETIL tot en met 1990 cijfers voor Limburg als geheel weergeeft en met ingang van 1991 de RBA-indeling Zuid-Limburg en Noord- en Midden-Limburg aanhoudt. ${ }^{14}$ Over Zuid-Limburg zoals gedefinieerd in dit onderzoek (tot en met Roermond) zijn dus geen cijfers beschikbaar en vanwege de veranderende gebiedsindeling is de vergelijkbaarheid van de cijfers door de jaren heen beperkt.

Ook heeft het ETIL een aantal studies specifiek over de pendel binnen en vanuit Limburg gepubliceerd. Cijfers over de uitwisseling van arbeidskrachten tussen de verschillende gewesten in Limburg en met de rest van Nederland zijn verschenen in Limburgse Pendel 1977-1985 $(1986,14,16)$ en Intergemeentelijke pendel in Limburg (1993, tabel 3-7). De eerste studie baseert zich volledig op cijfers afkomstig van het CBS en vermeldt ook cijfers over de pendel met Duitsland en België. Dit komt de vergelijkbaarheid van de cijfers daarover ten goede. De tweede studie baseert haar cijfers over pendel binnen Nederland op het Vestigingenonderzoek van het Landelijk Informatie Systeem voor Arbeidsplaatsen en vestigingen (LISA) uit 1991, waarbij bedrijven zijn gevraagd naar de woongemeenten van hun personeel dat minimaal 15 uur per week werkte. Deze zijn aangevuld met gegevens uit gelijksoortige vestigingenonderzoeken uit de provincies Noord-Brabant en Gelderland uit 1990. Daarnaast zijn voor de grenspendel cijfers van het CBS gebruikt, die uitsluitend op gewestelijk niveau beschikbaar waren. ${ }^{15}$ Voor beide publicaties van het ETIL geldt dat zij voor de binnenlandse pendel ook personen die niet verplicht waren verzekerd bij het ziekenfonds meerekenden. Cijfers uit beide publicaties worden samengebracht in de Limburgse Arbeidsmarkt Verkenning (LAV) uit $1993 \cdot{ }^{16}$ Deze cijfers zijn uiteindelijk gebruikt.

Verder is de Limburgse Arbeidsmarktverkenning (LAV) uit 1991 gebruikt voor de verdeling van de pendelaars naar woongewest in 1983, 1987 en 1991. Deze cijfers zijn gebaseerd op die van het CBS, maar wijken licht van af van de in deze studie op basis van de CBS-gegevens berekende cijfers voor Zuid-Limburg, omdat het CBS tot en met 1986 niet alle Zuid-Limburgse gewesten of rayons vermeldde. Over de periode na 1991 zijn er in de LAV geen pendelcijfers naar gewest meer gepubliceerd.

\section{Landesarbeitsamt Nordrhein-Westfalen}

In Duitsland zijn er slechts beperkt gegevens over de grenspendel vanuit Zuid-Limburg beschikbaar. Het Arbeitsamt Aachen zou slechts tot 1970 schattingen maken van het aantal grens-

\footnotetext{
12 Voor de beroepsbevolking zijn cijfers uit de LSEV gebruikt omdat hier in tegenstelling tot in de Limburgse Arbeidsmarkt Verkenningen ook cijfers over het jaar 1981 en 1985 zijn gepubliceerd.

13 Daarbij werden cijfers vanaf 1985 gepresenteerd.

14 Zie ETIL, LSEV 1992, 41; Idem, LSEV, 1993, 45.

15 Hanraets, Intergemeentelijke pendel in Limburg 5: het ETIL berekent het aantal grensarbeiders uit Zuid- (en Midden-)Limburg in deze publicaties anders dan in dit onderzoek is gebeurd, maar het geeft niet aan hoe. Toch wijken haar cijfers niet sterk af van de cijfers waar in dit hoofdstuk van is uitgegaan.

16 Zie ETIL, Limburgse Arbeidsmarktverkenning 1993, 33.
} 
arbeiders. ${ }^{17}$ Het Landesarbeitsamt Nordrhein-Westfalen (LAA-NRW) beschikt over cijfers over de ontwikkeling van het aantal grensarbeiders vanuit Nederland naar de Regio Aken. Ik heb via e-mail een bestand met gegevens over alle Nederlandse pendelaars in de Regio Aken ontvangen. Het betrof cijfers over het geslacht van de grensarbeiders, de gemeenten waarin zij werkten, de grootte van de bedrijven waar ze werkten en de beroepsgroep waartoe zij behoorden. ${ }^{18}$ Deze gegevens waren net als die van het CBS gebaseerd op de gegevens van de ziekenfondsen en kennen daarmee dezelfde beperkingen. Verder is de grenspendel naar beroepsklasse natuurlijk niet één op één te vergelijken met de pendel naar bedrijfstak, waarnaar de cijfers van het DBA zijn ingedeeld, maar geeft deze daar wel een goede indicatie van, zeker gezien het feit dat de beroepsgroepen deels zijn ingedeeld naar bedrijfstak.

Daarnaast is gebruik gemaakt van de publicatie Pendler in Nordrhein-Westfalen. Vorläufige Daten 2001/2002, die ook uitging van de ziekenfondsverzekerden. In deze publicatie worden gegevens vermeld over het geslacht, de nationaliteit, de functiegroep (Angestellte-Arbeiter), de opleiding, de lengte van de werkweek (deeltijd of voltijd) en de leeftijd van Nederlandse grensarbeiders in Noordrijn-Westfalen.

\section{GEBIEDSINDELING STATISTIEKEN}

\section{Nederland}

Het onderzoeksgebied is het gebied dat ten tijde van de mijnsluitingen tot Herstructureringsgebied werd benoemd, bestaande uit de COROP-gebieden Zuid-Limburg en Midden-Limburg exclusief Swalmen en de gemeenten van Rayon Roermond ten westen van de Maas. ${ }^{19}$

17 Walpot, De Euregio Maas-Rijn, 75; zie ook LD, 10-7-1969: het Arbeitsamt Aachen zou het aantal grensarbeiders baseren op het aantal uitgegeven werkvergunningen, die op basis van de Europese Verordening 1612/68 met ingang 1 januari 1970 niet meer nodig waren. 18 Ook het Landesamt für Datenverarbeitung und Statistik Nordrhein-Westfalen (LDS-NRW) is benaderd in verband met cijfers over de grenspendel vanuit Zuid-Limburg. Het gaf echter aan uitsluitend te beschikken over gegevens met betrekking tot de arbeidsstromen uit Duitsland.

19 Exclusief de (voormalige) gemeenten Swalmen, Baexem, Beegden, Grathem, Haelen, Heel en Panheel, Heythuizen, Horn, Roggel, Swalmen, Thorn, Weert, Hunsel, Nederwert, Stamproy, Weert (zie Derks, Perspectief voor Limburg, 10). 


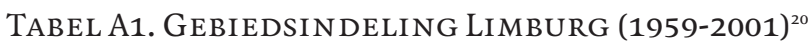

\begin{tabular}{|c|c|c|c|c|c|c|c|c|c|c|}
\hline 䄽 & \multirow{2}{*}{\multicolumn{8}{|c|}{ 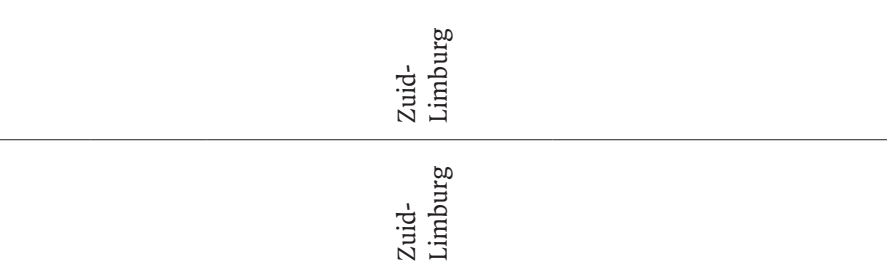 }} & \multicolumn{2}{|c|}{ 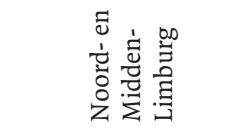 } \\
\hline 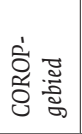 & & & & & & & & & 密蒂 & 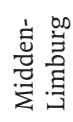 \\
\hline 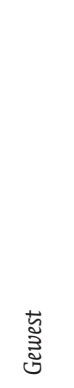 & \multicolumn{2}{|c|}{ 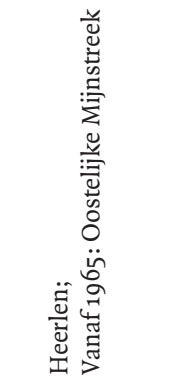 } & \multirow{2}{*}{ 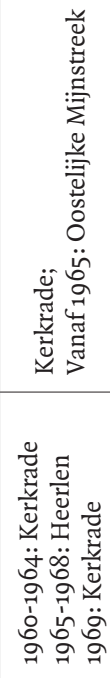 } & \multirow{2}{*}{ 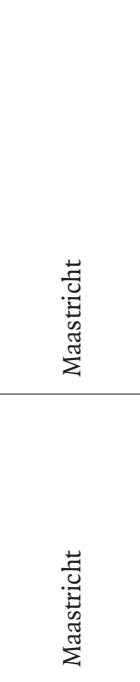 } & \multirow{2}{*}{ 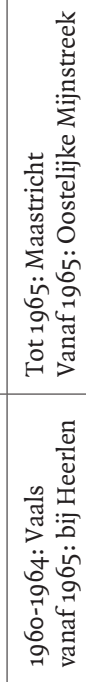 } & \multirow{2}{*}{ 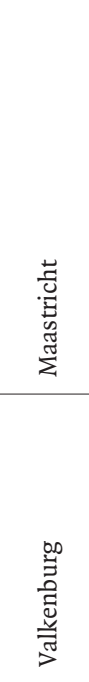 } & \multicolumn{2}{|c|}{ 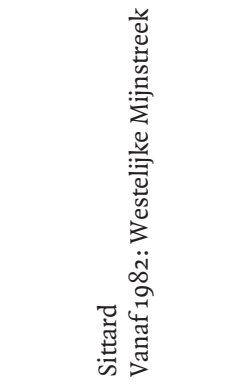 } & 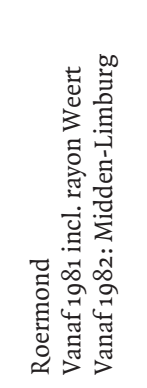 & 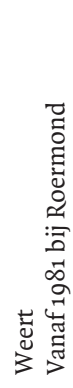 \\
\hline $\begin{array}{l}\overline{5} \\
\stackrel{\bar{\sigma}}{\vec{c}}\end{array}$ & 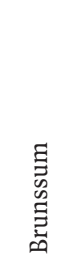 & 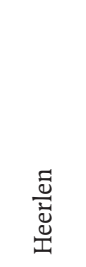 & & & & & 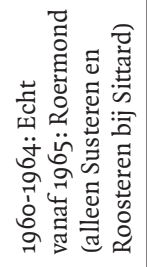 & 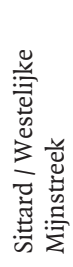 & 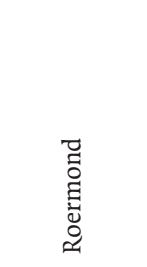 & $\begin{array}{l}\text { प्ँ } \\
\stackrel{\Delta}{3}\end{array}$ \\
\hline 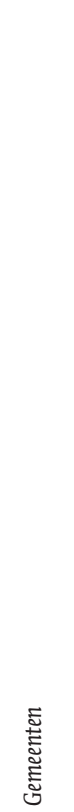 & 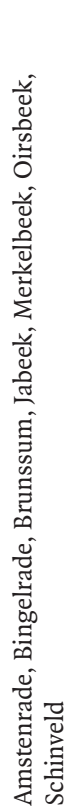 & 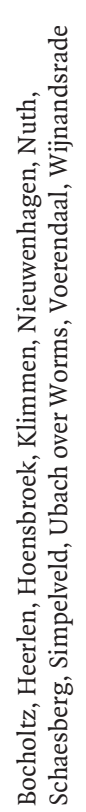 & 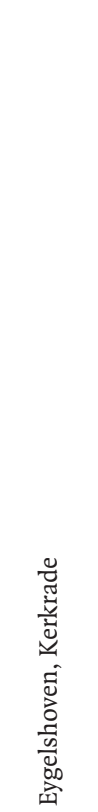 & 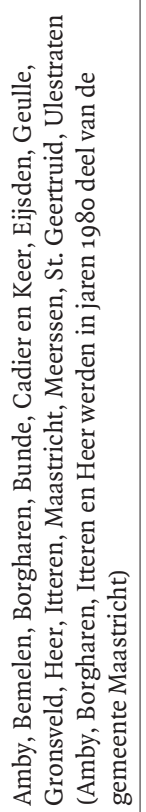 & 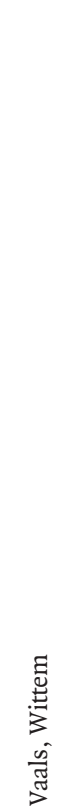 & 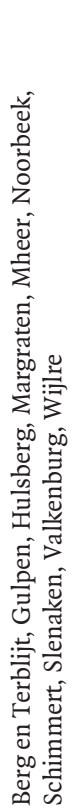 & 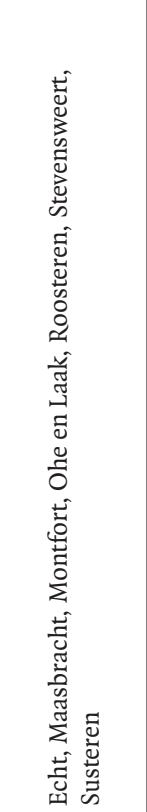 & 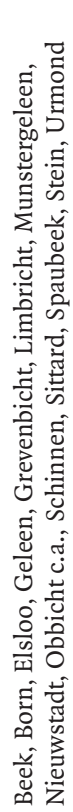 & 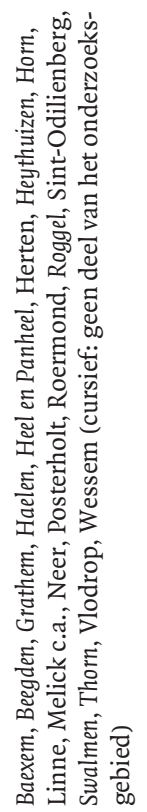 & 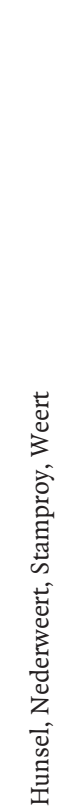 \\
\hline
\end{tabular}

20 Op basis van DBA, Arbeidsmarktbeschrijuing 1954-1985; Wolters et al., Arbeid in beweging, 133. 


\section{Duitsland}

Bij de beschrijving van de ontwikkelingen aan Duitse zijde van de grens ging de aandacht in dit boek vooral uit naar de huidige Regio Aachen.

TABel A2. Gebiedsindeling Regio AKen (1995) ${ }^{21}$

\begin{tabular}{|c|c|c|c|}
\hline Gemeenten & Rayons & Kreise & Arbeidsbureaus \\
\hline Aken & Aken & $\begin{array}{l}\text { Kreisfreie } \\
\text { Stadt } \\
\text { Aachen }\end{array}$ & \multirow{8}{*}{ Aken } \\
\hline Alsdorf, Baesweiler, Herzogenrath, Würselen & Alsdorf & \multirow{4}{*}{ Aken } & \\
\hline Eschweiler & Eschweiler & & \\
\hline Monschau, Roetgen, Simmerath & Monschau & & \\
\hline Stolberg & Stolberg & & \\
\hline Erkelenz, Hückelhoven, Wegberg & Erkelenz & \multirow{3}{*}{ Heinsberg } & \\
\hline Geilenkirchen, Übach-Palenberg & Geilenkirchen & & \\
\hline $\begin{array}{l}\text { Gangelt, Heinsberg, Selfkant, Waldfeucht, } \\
\text { Wassenberg }\end{array}$ & Heinsberg & & \\
\hline $\begin{array}{l}\text { Düren, Heimbach, Hürtgenwald, Inden, Kreuzau, } \\
\text { Langerwehe, Merzenich, Nideggen, Niederzier, } \\
\text { Nörvenich, Vettweiss }\end{array}$ & Düren & \multirow[t]{2}{*}{ Düren } & \multirow[t]{2}{*}{ Düren } \\
\hline Aldenhove, Jülich, Linnich, Titz & Jülich & & \\
\hline $\begin{array}{l}\text { Bad Münstereifel, Euskirchen, Mechernich, } \\
\text { Weilerswist, Zülpich }\end{array}$ & Euskirchen & \multirow{2}{*}{ Euskirchen } & \multirow{2}{*}{ Brühl } \\
\hline $\begin{array}{l}\text { Blankenheim, Dahlem, Hellenthal, Kall, Nettersheim, } \\
\text { Schleiden }\end{array}$ & Kall & & \\
\hline
\end{tabular}




\section{Appendix B \\ Het krantenonderzoek}

In totaal zijn 405 artikelen geanalyseerd die in de periode vanaf 1957 tot en met 2001 in de regionale dagbladen zijn verschenen en handelden over grensarbeid(ers) uit Zuid-Limburg in Duitsland. ${ }^{22}$ Voor het verzamelen van dit materiaal is gebruik gemaakt van de thematisch ontsloten krantenknipselarchieven van het Stadsarchief Heerlen, het Sociaal Historisch Centrum voor Limburg (SHCL), het Economisch Technologisch Instituut Limburg (ETIL), de Nederlandse Katholieke Mijnwerkersbond (NKMB) en de Provincie Limburg. Daaruit is een selectie gemaakt van de artikelen waarbij de woorden of zinsneden 'grensarbeid(ers)', 'grenspendel(aars)', '(Duitsland-)pendel(aars)', 'Duitslandgangers', 'arbeiders in Duitsland' of 'werk(en) in Duitsland' voorkwamen in de kop, subkop, of lead. Een aantal artikelen waarbij de grenspendel uitsluitend in de tekst voorkwam, is toch gebruikt, omdat ze wel uitgebreid op het verschijnsel ingingen. Vervolgens zijn alleen die artikelen geselecteerd die (mede) betrekking hadden op pendel vanuit Zuid-Limburg naar Duitsland (zie tabel B1 voor een overzicht van het aantal gebruikte artikelen per archief).

TABEL B1. VERDELING GEVON DEN KRANTENARTIKELEN NAAR ARCHIEF. ${ }^{23}$

\begin{tabular}{|c|c|c|c|c|c|}
\hline & \multirow{2}{*}{$\begin{array}{l}\text { Stadsarikiof Horles } \\
\text { (nu Rjjkkheye) }\end{array}$} & \multicolumn{4}{|c|}{ Soriagl-Historish Comtrum voor Limburg } \\
\hline & & NKMB & $\begin{array}{l}\text { Provincie } \\
\text { Limbarg }\end{array}$ & ETIL. & Eigen collectit \\
\hline $1957^{* 1961}$ & 22 & & & & 10 \\
\hline $1962-1966$ & 17 & & & & \\
\hline $1967-1971$ & 49 & 53 & & 1 & \\
\hline $1972-1976$ & t11 & & & & \\
\hline $1977^{-19} 81$ & & & & 17 & \\
\hline $1982-1986$ & 4 & & & 8 & \\
\hline $1987-1991$ & 3 & & 19 & 4 & \\
\hline $1992-1996$ & 2 & & $4^{6}$ & 4 & \\
\hline $1997-2001$ & & & 45 & & \\
\hline
\end{tabular}

22 Over de jaren 1958 en 1959 zijn geen artikelen gevonden. Om wel een indruk te krijgen van de berichtgeving aan het einde van de jaren vijftig is gebruik gemaakt van de twee artikelen die voor het jaar 1957 zijn gevonden.

23 Tien artikelen zijn in twee of meer archieven aangetroffen, waardoor het opgetelde aantal artikelen die in de verschillende archieven zijn gevonden op 415 uitkomt. Overigens verschenen 52 van de 53 artikelen uit het NKMB-archief in 1970 en 1971. De toonzetting van deze artikelen was overwegend negatief. De artikelen die over de periode vanaf 1967 tot en met 1971 in het Stadsarchief Heerlen zijn gevonden waren wat gelijkmatiger verdeeld over de jaren en waren vaker 'neutraal', omdat er dikwijls uitsluitend cijfers werden gepresenteerd over de ontwikkeling van de pendelstromen (vooral in 1967 toen als gevolg van de recessie het aantal grensarbeiders afnam en in 1968 toen het aantal grensarbeiders weer begon te groeien). 


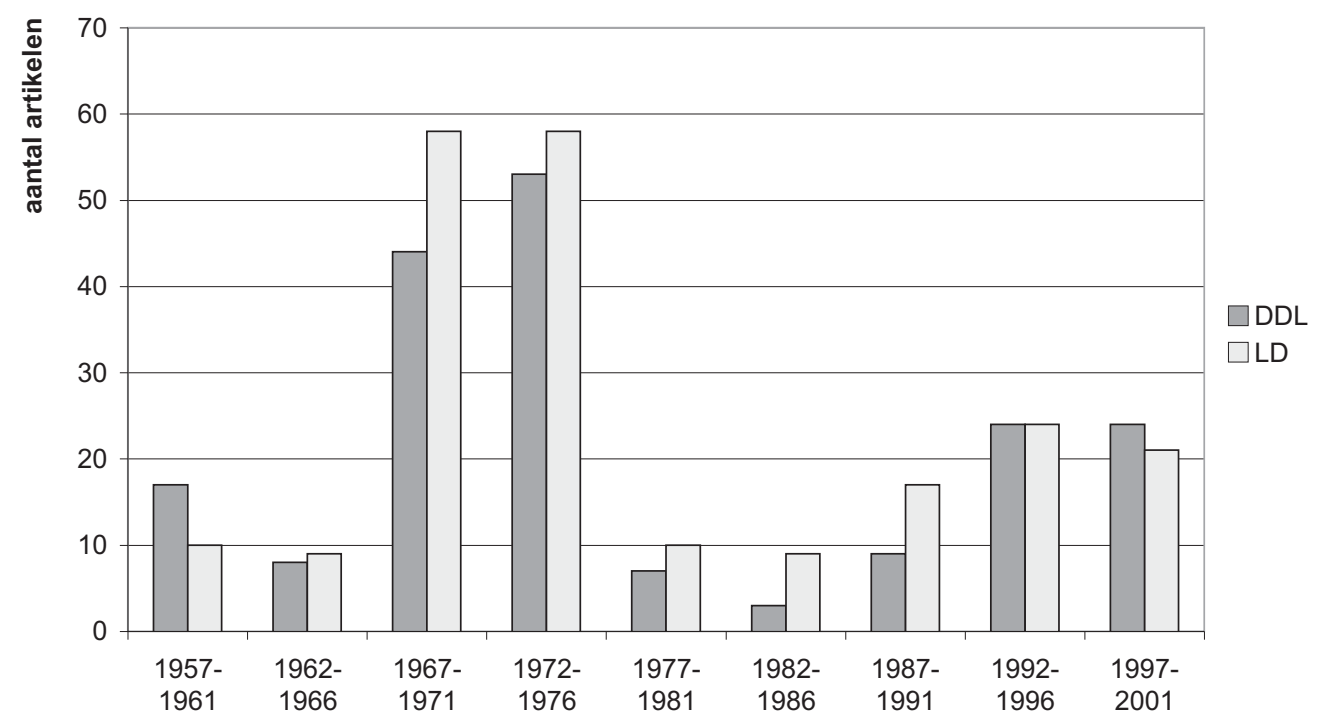

Een nadeel van deze steekproef is dat de selectiecriteria van de afzonderlijke archieven onbekend zijn. Het is daarom onzeker of het materiaal in deze archieven uitputtend is en of de inhoud van de archieven volledig vergelijkbaar is. Er was af en toe sprake van overlap, maar dat was lang niet altijd het geval. Gezien het grote aantal artikelen dat is gevonden en het gebruik van verschillende archieven, geeft de steekproef wel een goede indicatie van de ontwikkeling van de beeldvorming rond grensarbeid(ers) in deze periode. Het gaat er immers om de algemene teneur te beschrijven.

Figuur B1 geeft een overzicht van de verdeling van de gevonden artikelen over de twee dagbladen. Er is ongeveer een gelijk aantal artikelen over grensarbeid verschenen in beide kranten en vaak verschenen deze op nagenoeg hetzelfde moment. Door de jaren heen besteedde soms de ene en dan weer de andere krant meer aandacht aan de grenspendel. De verschillen zijn echter redelijk klein.

De analyse van de artikelen is als volgt uitgevoerd. Nadat zij allemaal waren gekopieerd en gelezen, zijn ze kort samengevat en zijn de relevante passages in de teksten gemarkeerd. In het computerprogramma Access is vervolgens een database aangemaakt om de kwantificeerbare kenmerken te registreren. Daarbij ging de aandacht uit naar de kwantitatieve spreiding van de artikelen door de jaren heen, het centrale thema van het artikel, de toonzetting van de artikelen en de verschillende partijen die in het artikel werden aangehaald. In het kader van de kwalitatieve analyse zijn citaten met veel voorkomende, maar ook opvallend afwijkende karakteriseringen, oordelen en metaforen, in een Word-bestand opgenomen. Aan deze fragmenten zijn op inductieve wijze codes toegekend die verwijzen naar het aspect van de grenspendel dat er aan de orde kwam. Om het grotere geheel niet uit het oog te verliezen is het materiaal telkens in samenhang met het originele artikel en het kwantitatieve bestand bestudeerd. De inhoud 
van de artikelen is zoveel mogelijk in het licht van ontwikkelingen in de specifieke ruimtelijke en historische context geanalyseerd. Op deze manier zijn zowel de manifeste betekenis als de meer latente vanzelfsprekendheden zo veel mogelijk achterhaald.

\section{Kwantitatieve analyse krantenknipsels}

Hieronder volgt een overzicht van de categorieën die zijn gebruikt bij de kwantitatieve analyse van de krantenartikelen.

\section{Oordeel over grensarbeid}

Afkeuring:

Grensarbeid als iets dat schade zou toebrengen aan de status quo of het bereiken van nastrevenswaardig geachte doelstellingen zou bemoeilijken en dus diende te worden teruggedrongen. Dit uitte zich in de kranten in de mening dat grensarbeid:

- schadelijk was voor de (Zuid-)Limburgse arbeidsmarkt, omdat:

- hij het arbeidsaanbod beperkte (grote omvang en eenzijdigheid) en zo de ontwikkeling van de (Zuid-) Limburgse arbeidsmarkt remde. Op deze manier hield de grenspendel (Zuid-)Limburg perifeer en droeg hij bij aan vergroting ontwikkelingsachterstand ten opzichte van andere delen van Nederland: bijv. afhankelijkheid van de Duitse conjunctuur en Duitse prestatiesysteem (waardoor oudere pendelaars worden ontslagen omdat ze niet meer aan eisen kunnen voldoen).

N.B. artikelen waarin werd gewezen op de verhoging van de regionale werkloosheid door de terugkeer van grensarbeiders, maar waar dit niet in verband werd gebracht met afhankelijkheid van de Duitse arbeidsmarkt of de noodzaak van een zelfstandig functionerende arbeidsmarkt in Limburg, zijn bij 'neutraal' ingedeeld.

- schadelijk was voor de Nederlandse economie:

- doordat de pendel haaks stond op het naoorlogs economisch beleid (geleide loonpolitiek)

- doordat de pendel ten koste van de Nederlandse schatkist ging

- schadelijk was voor grensarbeiders en hun gezinnen:

- door fraude van koppelbazen/onderaannemers

- door de hoge werkdruk en de slechte arbeidsomstandigheden

- doordat de pendel schadelijk was voor het gezinsleven

- doordat de pendelende meisjes een fabrieksmentaliteit ontwikkelden en ook jongens niet verzekerd waren van vormingsonderwijs

Acceptatie:

Grensarbeid als activiteit die niet hoefde te worden teruggedrongen. Dit uitte zich in de kranten in de mening dat:

- grensarbeiders de dupe waren van de achterblijvende harmonisatie van nationale wetgevingen. Grenspendel was een activiteit die onrechtvaardig geachte nadelen met zich meebracht. Deze nadelen dienden te worden opgeheven, opdat de grenspendelaars dezelfde rechten zouden genieten als arbeidskrachten die in hun woonland werkten. De pendel diende dus te worden gefaciliteerd. 


\section{Goedkeuring:}

Grensarbeid als een bezigheid die een bijdrage leverde aan positief beoordeelde ontwikkelingen en het bereiken van nastrevenswaardige doelen. Grensarbeid diende dus te worden gestimuleerd. Dit manifesteerde zich in de kranten in de opinie dat:

- grensarbeid een positieve invloed had op de Limburgse arbeidsmarkt en de regionale ontwikkeling

- grensarbeid aan de grensarbeiders zelf voordelen bood:

- betere arbeidsvoorwaarden (jaren 1960 en 1970)

- grensarbeid een positieve invloed had op de Duitse arbeidsmarkt:

- i.v.m. tekort arbeidskrachten Duitsland

- grensarbeid een positieve invloed had op de Nederlandse economie:

- i.v.m. besteding inkomen in Nederland

- grensarbeiders pioniers waren van Europese integratie:

- i.v.m. belichamen het vrij verkeer van werknemers

- grensarbeid niet mocht worden verhinderd door discrepanties tussen nationale wet- en regelgeving

Verschillende meningen:

In één artikel keurden één of meerdere partijen het werken in Duitsland af, accepteerden ze het en/of keurden ze het goed.

Geen mening:

Artikelen waarin zonder duidelijk oordeel gegevens over grensarbeid werden gepresenteerd, zoals cijfermateriaal.

\section{Partijen}

Indien een evenement, rapport, mening of een vertegenwoordiger van een bepaalde partij (een maatschappelijke organisatie of groep) werd aangehaald of uitdrukkelijk werd genoemd in relatie tot het werken in Duitsland, is een artikel aan een bepaalde partij gekoppeld. In één artikel konden meerdere partijen aan bod komen.

De onderscheiden partijen zijn:

- Regionale autoriteiten (NL): organen of personen die de Nederlandse overheid op provinciaal, regionaal of lokaal niveau vertegenwoordigden, zoals Gedeputeerde Staten van Limburg, het Districtsbureau voor de Arbeidsvoorziening in Limburg (DBA) en Stichting Economische Ontwikkeling Limburg (SEOL).

- Regionale politici (NL): leden van Provinciale Staten en gemeenteraden.

- Nationale autoriteiten (NL): organen of personen die de overheid op landelijk niveau vertegenwoordigden.

- Nationale politici (NL): leden van de Eerste en Tweede Kamer (het betrof hier vooral uit Limburg afkomstige politici).

- Duitse autoriteiten: vanwege de beperkte aanwezigheid van Duitse autoriteiten in de berichtgeving zijn organen of personen die de Duitse overheid vertegenwoordigden, zowel op nationaal, als op deelstaat- en op lokaal niveau, bij elkaar opgeteld. Het betrof bijvoorbeeld de Duitse regering, het Landesarbeitsamt Noordrijn-Westfalen en het Arbeitsamt Aken. 
- Europese autoriteiten: organen of personen die het bestuur van de Europese Unie en haar voorgangers vertegenwoordigen, zoals de Europese Commissie.

- Europese politici: leden van het Europees Parlement.

- Euregionale autoriteiten: organen of personen die de Euregio Maas-Rijn vertegenwoordigen, zoals diens bestuur of Eures Maas-Rijn.

- Nederlandse werkgevers(organisaties): zowel individuele Nederlandse werkgevers als landelijke en regionale afdelingen van Nederlandse werkgeversorganisaties.

- Nederlandse werknemersorganisaties: zowel landelijke vakbonden als Limburgse afdelingen van Nederlandse vakbonden.

- Duitse werkgevers(organisaties): zowel individuele Duitse werkgevers als landelijke en regionale afdelingen van Duitse werkgeversorganisaties.

- Duitse werknemersorganisaties: zowel landelijke vakbonden als regionale afdelingen van Duitse vakbonden.

- Euregionale werkgeversorganisatie: Stichting Werkgevers Euregio Maas-Rijn.

- Euregionale werknemersorganisatie: Interregionale Vakbondsraad Maas-Rijn (IVR): de Euresconsulent van de FNV is afhankelijk van hoe hij in het artikel werd benoemd ingedeeld bij de Euregionale vakbond of Nederlandse vakbonden meegeteld.

- Experts: deskundigen op het gebied van de grensoverschrijdende arbeidsmobiliteit werkzaam aan universiteiten of onderzoeksinstituten zoals het Economisch Technologisch Instituut Limburg (ETIL) en Research Centrum voor Onderwijs en Arbeidsmarkt (ROA).

- Grensarbeiders: individuele grensarbeiders en de Vereniging voor Europese Grenslandbewoners (VEG), een belangenvereniging voor grensarbeiders.

- Journalisten: uiteraard mediëren journalisten altijd de berichtgeving. Ze zijn hier apart geteld wanneer het redactionele commentaar betrof en als de betreffende journalist een expliciete mening verkondigde in een artikel over de grenspendel.

- Overig: zelden voorkomende partijen in de berichtgeving, zoals koppelbazen en verzekeraars. 


\section{Appendix C \\ De interviews}

In totaal zijn gedurende de zomer en het najaar van 2005 zesentwintig grensarbeid(st)ers en ex-grensarbeid(st)ers ${ }^{25}$ geïnterviewd. Deze informanten zijn op verschillende manieren bereikt. De meeste informanten zijn gevonden via een artikel over het onderzoek in de twee regionale dagbladen dat met name handelde over de berichtgeving in de pers. Daarbij was een oproep tot deelname aan de interviews geplaatst. De controversiële kop van het artikel 'Grensarbeiders: profiteurs en pioniers' leidde tot verontwaardiging onder veel grensarbeiders, waardoor zij in groten getale reageerden. Dit was aan de ene kant handig omdat het de gelegenheid bood om uit een grote groep grensarbeiders te selecteren. Van de andere kant kan dit ertoe hebben geleid dat mensen met bepaalde intenties reageerden. Zo gaven veel grensarbeiders aan het beeld van de 'profiteurs' dat in hun ogen in de krant werd neergezet, te willen nuanceren. Zij herkenden zich niet in dat beeld, omdat zij in een periode waarin er in Limburg weinig werk was in Duitsland waren gaan werken, en/of nadelige consequenties ondervonden van het werken in Duitsland vanwege sociale en fiscale systeemverschillen. Ook vroeg een aantal grensarbeiders voorafgaand aan of tijdens het gesprek of de problemen die zij ervoeren door het onderzoek aan de kaak zouden worden gesteld. Tijdens de interviews is erop gewezen dat dergelijke thema's wel aan de orde konden komen, maar dat de aandacht vooral uit zou gaan naar de alledaagse praktijk van het werken in Duitsland, los van de vraag of zij profiteurs waren of niet. Bovendien kan er bij deze manier van zoeken naar informanten altijd sprake zijn van zelfselectie, doordat deze mensen zich zelf moesten opgeven als informant. De kans bestaat dat bepaalde mensen zich bijvoorbeeld vanwege verlegenheid niet hebben opgegeven en langs deze weg dus niet zijn bereikt. ${ }^{26}$ Daarom zijn grensarbeiders ook op twee andere manieren benaderd om deel te nemen aan de interviews.

Allereerst zijn tijdens een zestal informatiemiddagen voor (ex-)grensarbeiders zo veel mogelijk grensarbeiders gevraagd een vragenlijst in te vullen over het werken in Duitsland. ${ }^{27}$ In deze enquête werd op het einde de vraag gesteld of zij wilden meewerken aan een interview. In totaal hebben vijftig grensarbeiders de enquête ingevuld, waarvan een ruime meerderheid zich bereid verklaarde tot deelname aan een interview. Op basis van de antwoorden op de vragen in de enquête is vervolgens een drietal informanten geselecteerd. Tenslotte is één grensarbeider via een andere informant en één via iemand uit het persoonlijk netwerk van de onderzoekster gevonden.

25 In plaats van steeds apart naar de grensarbeid(st)ers en ex-grensarbeid(st)ers te verwijzen, wordt hier volstaan met het woord 'grensarbeiders'.

26 Vgl. Yow, Recording oral history, 17-18.

27 Deze Deutsch-Niederländische Sprechtage für Grenzgänger worden ongeveer tweemaandelijks georganiseerd door Eures in de Euregio Maas-Rijn. 
Overigens zijn op deze manier vrijwel uitsluitend grensarbeiders bereikt die nog in ZuidLimburg woonden. Slechts één voormalige grensarbeider woonde op het moment van het interview in Duitsland. Dit kan tot enige vertekening van de resultaten leiden en daarmee is dan ook rekening gehouden bij de analyse van de interviews. Verder was een deel van de informanten buiten Limburg geboren, maar niemand in het buitenland en had één grensarbeider een Duitse vader en daarmee de Duitse nationaliteit, terwijl hij wel in Nederland was opgegroeid.

De interviews vonden op initiatief van de grensarbeiders nagenoeg allemaal bij hen thuis plaats. In de meeste gevallen werd alleen met hen gesproken. Soms was er ook een partner aanwezig, die af en toe in het gesprek participeerde. Twee grensarbeiders stelden voor elders af te spreken. Aan dat verzoek is beide keren gehoor gegeven. De voertaal gedurende vrijwel alle interviews was Nederlands. Slechts twee van de informanten schakelden als vanzelf over op het Limburgs dialect. Uiteindelijk duurden de interviews gemiddeld zo'n tweeëneenhalf uur. Om de privacy van de informanten te waarborgen, zijn zij in dit boek geanonimiseerd door pseudoniemen te gebruiken en door bijvoorbeeld de namen van hun werkgevers niet prijs te geven.

Als leidraad voor de interviews is gebruik gemaakt van een topiclijst waarop de thema's die aan de orde moesten komen en een aantal concrete vragen stonden vermeld, zoals de vraag waarom de persoon in kwestie in Duitsland was gaan werken. Om een indruk te krijgen van de positie van het werken in Duitsland in hun persoonlijke levensloop, is er behalve naar de periode die de grensarbeiders in Duitsland werk(t)en, ook geïnformeerd naar diverse aspecten van hun leven ervoor en, indien van toepassing, erna.$^{28}$ Gedurende de interviews zijn de informanten redelijk vrij gelaten in de volgorde en de mate waarin deze thema's aan de orde kwamen.

Het feit dat de onderzoekster zelf in Limburg is opgegroeid, het dialect beheerst en er op het moment van de interviews ook woonde, kan ertoe hebben geleid dat de informanten haar makkelijker in vertrouwen namen. Soms leidde een vermeend vergelijkbaar referentiekader er echter toe dat bepaalde zaken bekend werden verondersteld. In deze gevallen is zo veel mogelijk doorgevraagd om impliciete aannames bloot te leggen. Om enige afstand te bewaren zijn de interviews verder in het Nederlands begonnen. Zoals gezegd zijn uiteindelijk twee interviews in het dialect afgenomen.

De interviews zijn opgenomen met een cassetterecorder en nagenoeg letterlijk getranscribeerd. Vervolgens zijn ze geanalyseerd met behulp van een computerprogramma voor de analyse van kwalitatief onderzoeksmateriaal (atlas.ti). Daarbij zijn de interviews in fragmenten opgesplitst waaraan op inductieve wijze codes zijn toegekend. Op deze manier is het perspectief van de grensarbeiders zo veel mogelijk gerespecteerd en zijn de belangrijkste punten uit de interviews komen bovendrijven. De vraag hoe de praktijken en percepties van de (ex-) grensarbeiders zich tot de grens verhielden, fungeerde als leidraad bij de analyse van de interviews.

28 De term 'levensverhalen' wordt hier niet gehanteerd omdat, hoewel de hele levensloop van iedere informant gedurende de interviews aan de orde is gekomen, het niet de primaire doelstelling van de interviews was om levensverhalen op te tekenen. De eerdere en latere levensloop konden echter wel iets zeggen over de betekenis van het werken over de grens voor hen persoonlijk. 


\section{Overzicht informanten}

\begin{tabular}{|c|c|c|c|c|c|c|c|c|c|c|c|c|c|c|}
\hline 畺 & 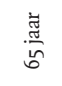 & 嘉 & 憘 & 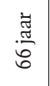 & 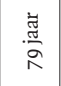 & $\frac{\vec{J}}{\tilde{J}}$ & 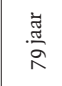 & 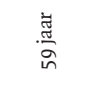 & $\frac{\text { 忽 }}{8}$ & 氶 & $\frac{\overrightarrow{. g}}{\text { in }}$ & $\frac{\vec{J}}{\frac{.}{f}}$ & 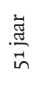 & 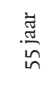 \\
\hline 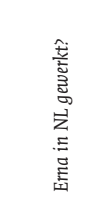 & ֻ̆ & 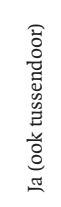 & $\check{z}$ & zั & $\Xi$ & 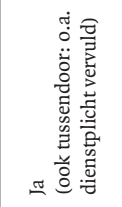 & zั̆ & 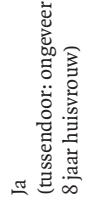 & $\approx$ & 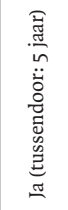 & 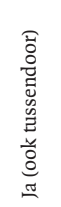 & 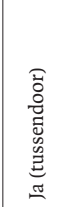 & $\ddot{z}$ & 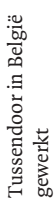 \\
\hline 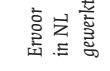 & $\Xi$ & $\cong$ & $\approx$ & $\Xi$ & $\Xi$ & zั & $\approx$ & $\approx$ & $\stackrel{\check{z}}{\mathrm{z}}$ & $\simeq$ & zั & そัँ & $\cong$ & $\cong$ \\
\hline 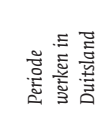 & 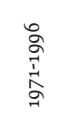 & 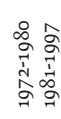 & 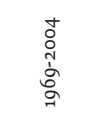 & 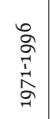 & 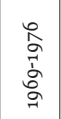 & 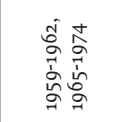 & 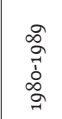 & 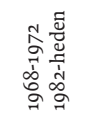 & 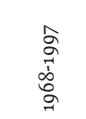 & 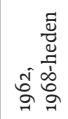 & 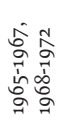 & 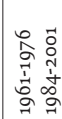 & 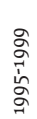 & 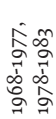 \\
\hline 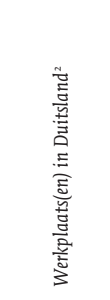 & $\frac{\overline{\tilde{V}}}{4}$ & 离 & : & 苟 & 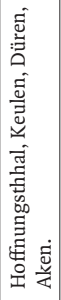 & 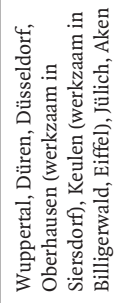 & 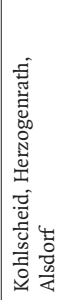 & 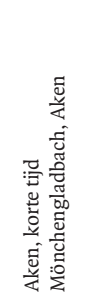 & $\frac{\overline{\tilde{g}}}{4}$ & 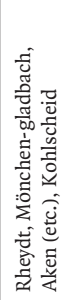 & 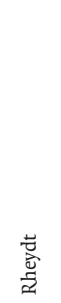 & $\frac{\bar{g}}{\frac{\tilde{u}}{4}}$ & 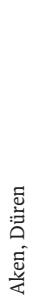 & 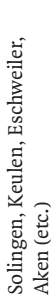 \\
\hline 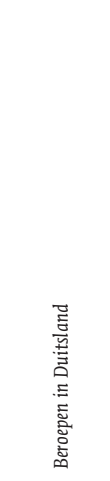 & 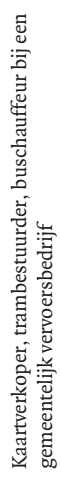 & 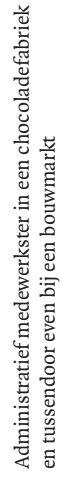 & 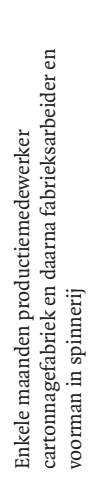 & 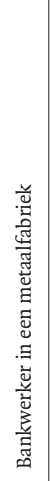 & 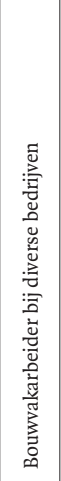 & 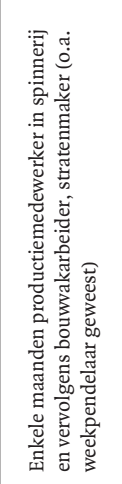 & 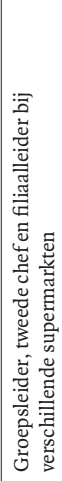 & 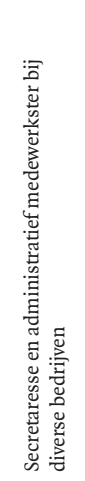 & 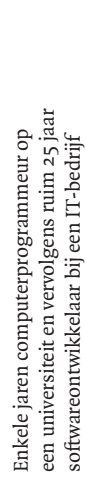 & 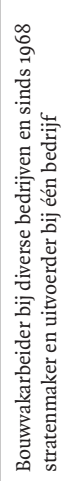 & 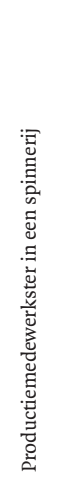 & 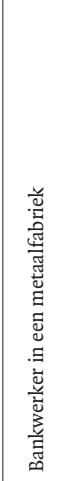 & 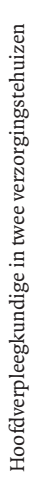 & 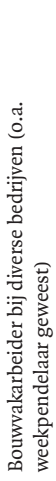 \\
\hline 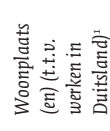 & 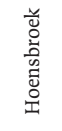 & $\stackrel{\substack{\pi \\
=}}{=}$ & 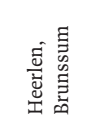 & 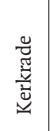 & 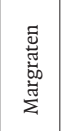 & 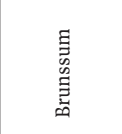 & 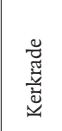 & 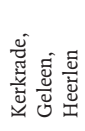 & 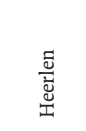 & 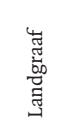 & 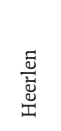 & 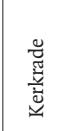 & 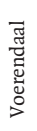 & 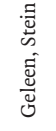 \\
\hline 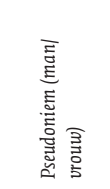 & 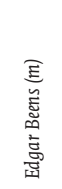 & 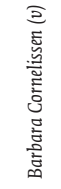 & 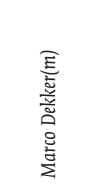 & 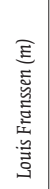 & 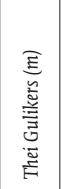 & 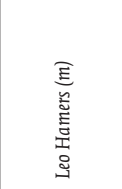 & 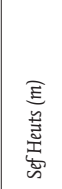 & 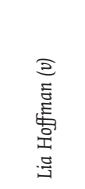 & 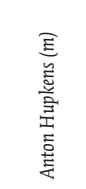 & 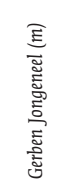 & 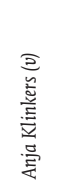 & 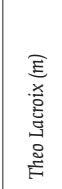 & 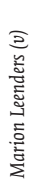 & $\begin{array}{l}\text { Е } \\
\underline{\underline{\underline{\Xi}}} \\
\underline{\underline{\underline{E}}}\end{array}$ \\
\hline
\end{tabular}

29 Hier is de gemeentelijke indeling van 2006 aangehouden.

30 Hierbij wordt de vestigingsplaats van de werkgever(s) als uitgangspunt genomen.

31 Ten tijde van het interview. 


\section{Overzicht informanten (vervolg)}

\begin{tabular}{|c|c|c|c|c|c|c|c|c|c|c|c|c|}
\hline 葷 & 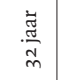 & 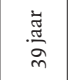 & 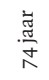 & 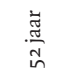 & 喜 & 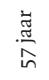 & 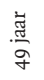 & $\begin{array}{l}\frac{\text { 岁 }}{i^{2}} \\
\text { in }\end{array}$ & 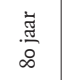 & 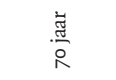 & 苞 & 趂 \\
\hline 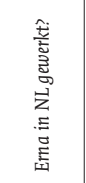 & そั & z̆ & $\cong$ & $\approx$ & $\cong$ & zั̆ & $\approx$ & z̆ & $\cong$ & 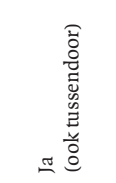 & $\underline{\sigma}$ & そ̆ \\
\hline 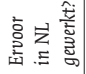 & $\approx$ & 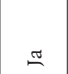 & $\cong$ & $\approx$ & z̆ & $\Xi$ & そัँ & zั & $\Xi$ & $\Xi$ & $\approx$ & $\cong$ \\
\hline 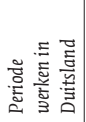 & 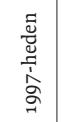 & 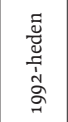 & $\begin{array}{l}\text { à } \\
\stackrel{1}{1} \\
\hat{\alpha}\end{array}$ & 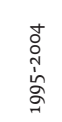 & $\begin{array}{l}\text { o } \\
\text { जे } \\
\dot{1} \\
\text { ôे }\end{array}$ & 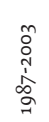 & 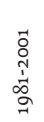 & 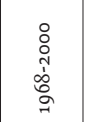 & 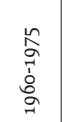 & 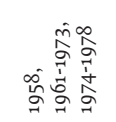 & 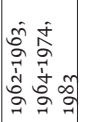 & 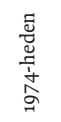 \\
\hline 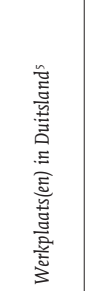 & 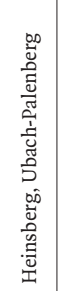 & 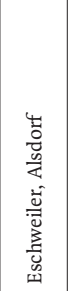 & 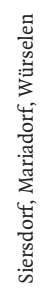 & 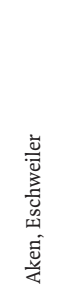 & 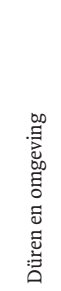 & 离 & 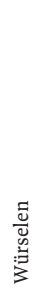 & 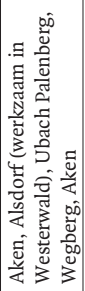 & 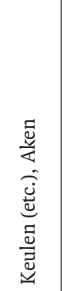 & 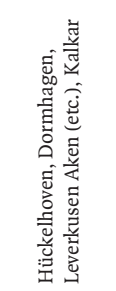 & 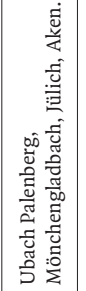 & $\begin{array}{l}\text { 品 } \\
\overline{0} \\
\overline{0}\end{array}$ \\
\hline 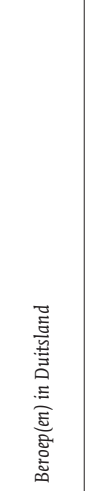 & 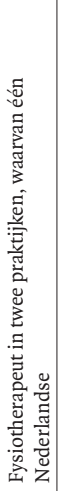 & 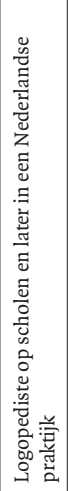 & 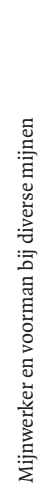 & 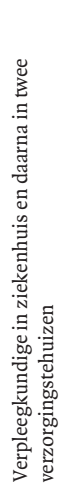 & 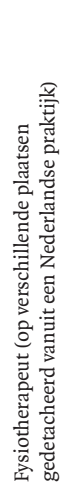 & 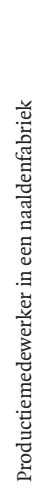 & 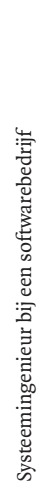 & 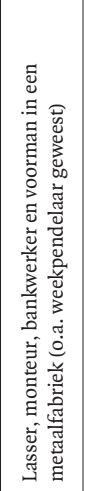 & 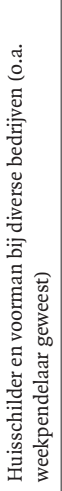 & 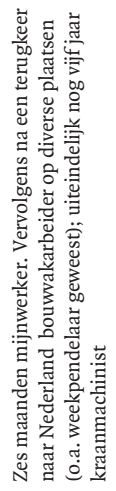 & 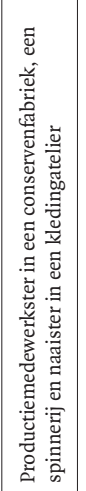 & 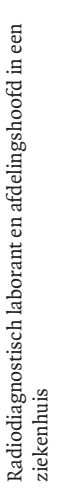 \\
\hline 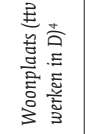 & 离 & 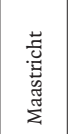 & 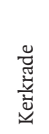 & 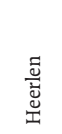 & 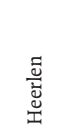 & 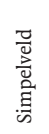 & 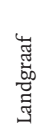 & 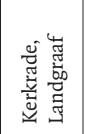 & 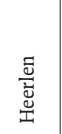 & 鴶 & 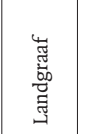 & 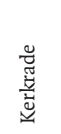 \\
\hline 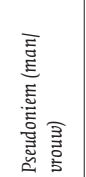 & 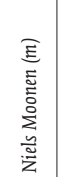 & 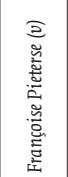 & 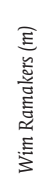 & 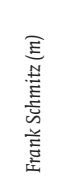 & 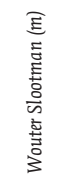 & 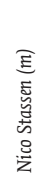 & 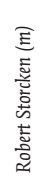 & 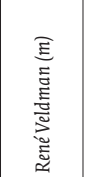 & 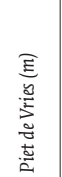 & 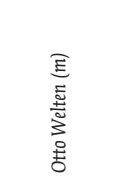 & 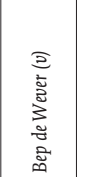 & 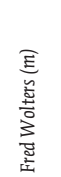 \\
\hline
\end{tabular}

32 Hier is de gemeentelijke indeling van 2006 aangehouden.

33 Hierbij wordt de vestigingsplaats van de werkgever(s) als uitgangspunt genomen.

34 Ten tijde van het interview. 


\section{Appendix D \\ Reisafstanden}

Om een indruk te geven van de reisafstanden tussen de belangrijkste Duitse en Nederlandse werkgelegenheidscentra, volgt hier een tabel op basis van cijfers van het NEI uit 1973 en een tabel op basis van recente berekeningen.

\section{TAbel D1. Pendelafstand tot De Belangrijkste Duitse Werkgelegen heids- CENTRA PER RAYON (IN KM) (1970) ${ }^{35}$}

\begin{tabular}{|c|c|c|c|c|c|c|c|}
\hline Van & Brunssum & Heerlen & Kerkrade & Maastricht & Valkenburg & Sittard & Roermond \\
\hline Naar & $\mathrm{km}$ & $\mathrm{km}$ & $\mathrm{km}$ & $\mathrm{km}$ & $\mathrm{km}$ & $\mathrm{km}$ & $\mathrm{km}$ \\
\hline Aken & 23 & 10 & 12 & 32 & 23 & 32 & 58 \\
\hline Düren & 52 & 45 & 40 & 65 & 56 & 47 & 66 \\
\hline Keulen & 90 & 94 & 69 & 99 & 90 & 81 & 85 \\
\hline Krefeld & 69 & 69 & 69 & 102 & 93 & 80 & 54 \\
\hline Mönchengladbach & 50 & 50 & 50 & 83 & 80 & 61 & 35 \\
\hline
\end{tabular}

\section{Tabel D2. Pendelafstand tussen belangrijKe gemeenten in Limburg en DUITSLAND (IN KM) (2007) ${ }^{36}$}

\begin{tabular}{|c|c|c|c|c|c|c|c|c|c|}
\hline Van & Echt & Heerlen & Kerkrade & Brunssum & Maastrich & Valkenburg & Sittard & $\begin{array}{l}\text { Vaals } \\
\mathrm{km}\end{array}$ & $\begin{array}{l}\text { Roermond } \\
\mathrm{km}\end{array}$ \\
\hline Naar & & & & & $\mathrm{km}$ & & & & \\
\hline Aken & 52 & 20 & 12 & 26 & 39 & 26 & 42 & 7 & 73 \\
\hline Düren & 81 & 49 & 41 & 55 & 68 & 56 & 72 & 41 & 102 \\
\hline Keulen & 118 & 86 & 79 & 92 & 106 & 93 & 109 & 79 & 92 \\
\hline Krefeld & 66 & 101 & 94 & 81 & 121 & 108 & 88 & 93 & 52 \\
\hline \multicolumn{10}{|l|}{ Mönchen- } \\
\hline gladbach & 52 & 79 & 71 & 59 & 98 & 85 & 74 & 71 & 37 \\
\hline Heerlen & 37 & - & 12 & 8 & 27 & 13 & 27 & 18 & 57 \\
\hline Kerkrade & 46 & 12 & - & 14 & 33 & 21 & 39 & 17 & 69 \\
\hline Brunssum & 23 & 8 & 14 & - & 33 & 15 & 12 & 31 & 53 \\
\hline Maastricht & 37 & 27 & 33 & 33 & - & 14 & 27 & 40 & 58 \\
\hline Sittard & 16 & 27 & 39 & 12 & 27 & 33 & - & 42 & 37 \\
\hline Roermond & 14 & 57 & 69 & 53 & 58 & 63 & 37 & 72 & - \\
\hline Venlo & 48 & 105 & 92 & 86 & 80 & 112 & 61 & 98 & 27 \\
\hline Weert & 31 & 64 & 76 & 59 & 63 & 70 & 44 & 79 & 25 \\
\hline
\end{tabular}

35 Bron: Van den Berg et al., De grenspendel in Limburg, 70. Het is helaas niet duidelijk waar zijn hun berekeningen precies op hebben gebaseerd.

${ }_{3} 6$ Berekening op basis van routeplanner ANWB (http://route.anwb.nl/routeplanner/servlet/rp, 17-2-2007). Daarin is de snelste route van het centrum van de ene plaats naar dat van de andere plaats gezocht (halven naar boven afgerond). Het is niet geheel duidelijk waar de afwijkingen van de cijfers van het NEI door worden veroorzaakt. Indien de afstanden in 2007 kleiner zijn kan dat natuurlijk samenhangen met eventueel betere verbindingen. 


\section{Geraadpleegde bronnen}

\section{Persdocumentatie}

\section{Rijckheyt (voorheen: Stadsarchief Heerlen)}

Krantenknipselmappen Arbeidsbemiddeling, pendel, werfacties, werkloosheid, 1957-1994 (doos 24 A t/m D, map 1-11)

\section{Sociaal Historisch Centrum voor Limburg}

Archief Algemeene Bond van Christelijke Mijnwerkers in Nederland te Heerlen (1908-1940) en de Nederlandse Katholieke Mijnwerkersbond en voorgangers te Heerlen (1907-1975) - Krantenknipsels Pendelaars 1965-1971 (EAN 65: 1933)

Krantenknipsels afkomstig van de Provincie Limburg

- Algemeen Bestuur: Euregio en Bestuurlijke grenscontacten 1990-2001

- Economische en Agrarische Zaken: Werkgelegenheids-|arbeidsmarktsituatie Limburg 1994-2001 (Doc 84)

Krantenknipsels van bedrijven gevestigd in Limburg (oorspronkelijk afkomstig van het ETIL)

Pendel/loonverschillen Doc. nr. 62, deel II, nr. 46 (voorlopige nummering juni 2004)

Krantenknipsels betreffende het politieke, sociale, economische en culturele leven in Limburg (Doc 0041)

\section{LITERATUUR}

Perspectievennota Zuid-Limburg Tweede Kamer der Staten-Generaal, zitting 1977-1978, 13969, nrs. 4-5.

Sociale Verzekeringspositie van grensarbeiders Tweede Kamer der Staten-Generaal, zitting 1982-1983, 17697, nrs. 1-2. Abbenhuis, M. 'Where War Met Peace: The Borders of the Neutral Netherlands with Belgium and Germany in the First World War, 1914-1918' Journal of Borderlands Studies 22 (2007) 53-78.

Agnew, J. Geopolitics: Re-Visioning World Politics. (Londen, 1998).

Amersfoort, H. van, 'From workers to immigrants: Turks and Moroccans in the Netherlands, 1965-1992', in: Cohen, R. (red.) Survey of World Migration (Cambridge, 1995), 308-312.

Anderson, B. Imagined Communities. Reflections on the Origins and Spread of Nationalism (Londen, New York, 1991 (eerste editie: 1983)).

Anderson, J., O’Dowd, L. ‘Borders, Border Regions and Territoriality: Contradictory Meanings, Changing Significance' Regional Studies 33 (1999) 593-604.

Anderson, J., O’Dowd, L., Wilson, T. 'Why Study Borders Now?' Regional and Federal Studies 12 (2002) 4, 1-12.

Anderson, M., Bort, E. The Frontiers of the European Union (Basingstoke, 2001).

Barth, F. 'Introduction' in: Barth, F. (red.) Ethnic Groups and Boundaries. The Social Organization of Culture Difference (Prospect Heights, 1998 (eerste editie: 1969)) 9-38.

Baud, M., Schendel, W. van 'Toward a Comparative History of Borderlands' Journal of World History 8 (1997) 211-242.

Baum, A. 'The European Trade Union Confederation' in: Zséll, G. (red.) European Labour Relations - Volume I: Common features (Aldershot, 1997) 334-346. 
Baycroft, T. 'Changing identities in the Franco-Belgian borderland in the nineteenth and twentieth centuries' French History 13 (1999) 417-438.

Beek, C. van, Samenwerking? Er zijn grenzen! Onderzoek naar de invloed van de culturele factor op het proces van economische en politiek bestuurlijke integratie in de Euregio Maas-Rijn (Rotterdam/Tilburg, 1996).

Berg, E., Houtum, H. van 'Prologue: A Border is Not a Border. Writing and Reading Borders in Space' in: Berg, E., Houtum, H. van (red.) Routing Borders Between Territories, Discourses and Practices (Aldershot, 2003) 1-10.

Berg, L. van den, Blokland, J., Bulthuis, R., Drewe, P., Hendriks, A. De grenspendel in Limburg. Een onderzoek naar motieven en context van de pendel op Duitsland (Rotterdam: NEI, 1973).

Blake, G. 'Boundary Permeability in Perspective' in: Nicol, H., Townsend-Gault, I. (red.) Holding the Line. Borders in a Global World (Vancouver/Toronto, 2005), 15-25.

Bois-Reymond, M. du, 'Over de methode van mondelinge geschiedenis' in: du Bois-Reymond, M., Wagemakers, T. (red.) Mondelinge geschiedenis. Over theorie en gebruik van mondelinge bronnen (Amsterdam, 1983) 9-27.

Bort, E. 'European Borders in Transition: the Internal and External Frontiers of the European Union' in: Nicol, H., Townsend-Gault, I. (red.) Holding the Line. Borders in a Global World (Vancouver/Toronto, 2005), 63-89.

Bourdieu, P. Outline of a theory of practice (Cambridge, 1977).

Boutillier, S., Laperche, B., Mudard, N. Frontaliers du Nord. Europe, regions, migrations (Parijs, 2002).

Bouwens, S. 'The Dynamics of Cross-Border Labour: Commuting from the Dutch to the German part of the Euregio Meuse-Rhine, 1960-2000' Journal of Borderland Studies 19 (2004) 135-153.

Bouwens, S. 'Werk in de marge? Grensarbeid vanuit het Nederlandse naar het Duitse deel van de Euregio Maas-Rijn, 1960-200o' Studies over de sociaal-economische geschiedenis van Limburg L (2005) 197-216.

Breuer, H. 'Strukturdaten zur Wirtschaftsregion Aachen 1979-1985' Informationen und Materialien zur Geographie der Euregio Maas-Rhein 19 (1986) 25-34.

Bucken-Knapp, G., Schack, M. 'Borders matter, but how?' in: Bucken-Knapp, G., Schack, M. (red.) Borders matter. Transboundary regions in contemporary Europe (Aabenraa, 2001) 13-26.

Bundesanstalt für Arbeit Landesarbeitsamt Nordrhein-Westfalen (LAA-NRW) Pendler in Nordrhein-Westfalen (Düsseldorf, 2003).

Bureau Duitse Zaken (BDZ), Werken en de sociale verzekering in Duitsland (Nijmegen, 2003).

Camp, R. op den, “Noch Fransch noch Pruissisch maar Nederlandsch!' Publieke opinie en Nederlands-nationaal gevoel in de Nederlandse provincie Limburg rond 1870' Maasgouw. Tijdschrift voor Limburgse geschiedenis en oudheidkunde 111 (1992) 81-102.

Camp, R. op den, 'Towards one Nation; the Province of Limburg and the Dutch Nation during the EighteenSeventies' in: Galema, A.; Henkes, B.; Te Velde, H. (red.) Images of the Nation: Different Meanings of Dutchness 1870-1940 (Amsterdam, 1993) 81-105.

Camp, H. van, Pilet, Y., Vermeulen, W., Nekkers, G., Sieben, I. Naar de arbeidsmarkt zonder grenzen. RAIL-Euregionaal Euregio Rijn-Maas-Noord, Euregio Maas-Rijn. Arbeidsmarktmonitor en pendelonderzoek (Maastricht: ETIL, ROA, 2001).

Camp, H. van, Sieben, I. 'Naar de arbeidsmarkt zonder grenzen? Euregio Rijn-Maas-Noord en Euregio MaasRijn' in: Maks, J. (red.) Eén munt, één Euregio? (Maastricht, 2002) 43-78.

Castells, M. The Informational City (Oxford, 1989).

Centraal Bureau voor de Statistiek (CBS) Sociale Maandstatistiek (Voorburg/Heerlen, 1970-1983).

Centraal Bureau voor de Statistiek (CBS) Supplement Sociaal-Economische Maandstatistiek 1984/6 (Voorburg/ Heerlen, 1984).

Centraal Bureau voor de Statistiek (CBS) Sociaal-Economische Maandstatistiek (Voorburg/Heerlen: 1984-2002).

Commissie van de Europese Gemeenschappen, Mededeling van de Commissie inzake de levens- en arbeidsvoorwaarden van de burgers uit de Gemeenschap die in de grensgebieden wonen, met name de grensarbeiders COM (1990) 561 def.

Commissie grensarbeiders, Rapport van de Commissie grensarbeiders (Den Haag, 2001).

Coördinatiecommissie Perspectievennota, Concept perspectievennota Zuid-Limburg (1977).

Corvers, F. 'De visie op grensregio's vanuit de Europese Commissie' in: Boekema, F. (red.) Grensregio's en arbeidsmarkten. Theoretische en empirische initiatieven (Assen, 2000) 17-28.

Cranssen, T. 'Marokkaanse mijnwerkers in Limburg, 1963, 1975' Studies over de sociaal-economische geschiedenis van Limburg XLVIII (2003) 120-148.

Creemers, R. Grensoverschrijdende migratie en pendel. Een inventariserende verkenning (Maastricht: ETIL, 1996).

Cunningham, H. 'Nations rebound? Crossing borders in a gated globe' Identities: Global Studies in Culture and Power 11 (2004) 329-350. 
Cunningham, H., Heyman, J. 'Introduction: Mobilities and Enclosures at Borders' Identities: Global Studies in Culture and Power 11 (2004) 289-302.

Dam, J. van, Grip, A. de, De Euregionale arbeidsmarkt: van fictie naar werkelijkheid Maastricht: ROA (Maastricht: ROA, 1991).

Davis, K., Brinkgreve, C. 'Inleiding: levensverhalen.' Amsterdams Sociologisch Tijdschrift - Themanummer Levensverhalen 29 (2002) 7-18.

Dekker, H. Nationaal favoritisme, germanofobie, en Europees burgerschap: socialisatie van emoties (Utrecht, 1999).

Denzen, H. van, Heijmans, W., Lommers, C. Een bijzonder bedriif in Limburg. Wel en wee van het Limburgs Dagblad (Heerlen, 1986).

Derix, J. Perspectief voor Limburg. Stappen en obstakels in het beleid rond de perspectievennota Zuid-Limburg, 1965-1990 (Leeuwarden/Maastricht, 1990).

Derks, W. Pendel 1973-1979 (Maastricht: ETIL, 1980).

Derks, W. Limburgse pendel 1977-1985 (Maastricht: ETIL, 1986).

Derks, W. Arbeidsmarkt Herstruktureringsgebied Zuid-Limburg, 1963-1988 (Maastricht: ETIL, 1989).

Derks, W. Zuid-Limburg: 25 jaar herstructurering (Maastricht: ETIL, 1990).

Dijk, J. van, Zanen, J. 'Grensoverschrijdende samenwerking en de arbeidsmarkt in de Eems-Dollardregio' in: Boekema, F. (red.) Grensregio's en arbeidsmarkten: theoretische en empirische perspectieven (Assen, 2000) 59-82.

Dinan, D. Europe Recast. A History of European Union (Basingstoke, 2004).

Districtsbureau voor de Arbeidsvoorziening in Limburg (DBA) Arbeidsmarktbeschrijuing van de Provincie Limburg (Maastricht, 1955-1986).

Donnan, H., Haller, D. 'Liminal no More. The Relevance of Borderland Studies' Ethnologia Europaea 30 (2000) 7-22.

Donnan, H., Wilson, T. Borders. Frontiers of identity, nation and state. (Oxford/ New York, 2001 (eerste editie: 1999)).

Dörrenbacher, P., Schulz, C. 'Cultural and regional integration. The case of the Saar-Lor-Lux cross-border labour market' in: Koter, M., Heffner, K. (red.) Multicultural regions and cities. Regions and Regionalism (LódzOpole, 1999) 125-139.

Dörrenbacher, P., Schulz, C. 'Economic integration in the Saar-Lorraine border region' in: Vlisteren, G. van, Wever, E. (red.) Borders and economic behaviour in Europe. A geographical approach (Assen, 2005) 10-24.

Ehlers, N. 'Tageszeitungen an Maas und Oder' Pp. 353-374 in: Schultz, H. (red.) Grenzen im Ostblock und ihre Überwindung (Berlijn, 2001) 353-374.

Ehlers, N., Buursink, J. 'Binational Cities: People, Institutions and Structures' in: Velde, M. van der, Houtum, H. van (red.) Borders, regions and people (Londen, 2000) 82-101.

Elbers, E. 'Interdisciplinariteit en onderzoeksprogramma's' in: Hagendoorn, L., Komter, A., Maier, R. (red.) Samenhang der Sociale Wetenschappen. Beloften en problemen van een interdisciplinaire werkwijze (Houten/Zaventem, 1994) 54-68.

Elias, N., Scotson, J. De gevestigden en de buitenstaanders. Een studie van de spanningen en machtsverhoudingen tussen twee arbeidersbuurten (Utrecht/Antwerpen, 1976).

Erdkamp, J., Thewissen-Moors, L., Bekkers, H. Roerstreek in oude prenten (1885-1965) (St. Odiliënberg, 1989).

Ergo, P. et al., Het structuurbeleid en de verschillende gebieden van Europa: samenwerking zonder grenzen (Luxemburg: Bureau Officiële Publicaties der Europese Gemeenschappen, 2002).

Eschweiler, O., Indetzki, H-D. 'Wirtschaftsraum Aachen: Von der Montanregion zur Technologieregion' in: Eschweiler, O., Eyll, K. van (red.) Wirtschaftsgeschichte der Region Aachen (Keulen, 2000) 119-175.

Esping-Andersen, G. 'After the golden age? Welfare state dilemmas in a global economy' in: Esping-Andersen, G. (red.) Welfare states in transition. National adaptations in global economies (London/Thousand Oaks/New Delhi, 1996) 1-31.

Economisch Technologisch Instituut Limburg (ETIL) Samenvatting en kanttekeningen bij het rapport DE GRENSPENDEL IN LIMBURG (Maastricht, 1973).

Economisch Technologisch Instituut Limburg (ETIL) Limburgse Arbeidsmarktverkenning (LAV) (Maastricht, 19821998).

Economisch Technologisch Instituut Limburg (ETIL) Limburgse Sociaal-Economische Verkenning (LSEV) (Maastricht, 1980-1999).

Economisch Technologisch Instituut Limburg (ETIL) Limburg in Beeld. Limburgse Sociaal-Economische Verkenning (Maastricht, 2000-2002).

Fischer, P., Straubhaar, T. 'The Impact of Mobility on Regional Development' in: De Gijsel, P., Janssen, M., 
Wenzel, H-J., Woltering, M. Understanding European Cross-Border Labour Markets. Issues in Economic Cross-Border Relations (Malburg, 1999) 71-106.

Gellner, E. Nations and Nationalism (Oxford, 1983).

Geurts, P., Janssen, A. 'Ruim een eeuw geschiedoefening met betrekking tot de Nederlandse provincie Limburg. Enige historiografische aspecten' Publications SHAL 125 (1989) 47-99.

Giddens, A. The constitution of society. Outline of the theory of structuration (Cambridge, 1984).

Giddens, A. The nation-state and violence (Cambridge, Oxford, 1985).

Gijsel, P. de, Janssen, M. 'Grensoverschrijdende samenwerking vanuit economisch perspectief' in: Spoormans, H., Reichenbach, E., Korsten, A. (red.) Grenzen over. Aspecten van grensoverschrijdende samenwerking (Bussum, 1999) 54-68.

Gijsel, P. de, Janssen, M., Wenzel, H-J., Woltering, M. 'Concepts and issues in European cross-border labour economics: an introduction' in: De Gijsel, P., Janssen, M., Wenzel, H., Woltering, M. (red.) Understanding European cross-border labour markets. Issues in economic cross-border relations (Malburg, 1999) 7-22.

Goedings, S. Labor Migration in an Integrating Europe. National Migration Policies and the Free Movement of Workers, 1950-1968 (Den Haag, 2005).

Goethem, W. van, Doumen, P., Grensarbeid in de Euregio Maas-Rijn. Verklaringen en percepties vanuit werkgeversperspectief (Diepenbeek, 1995).

Goossens, J. 'De evolutie van het taalgebruik in de beide Limburgen' in: Eenheid en scheiding van de beide Limburgen. Verslagbundel van het op 26 mei 1989 te Alden Biesen gehouden congres bij gelegenheid van de herdenking van 150 jaar beide Limburgen (Leeuwarden, 1989) 213-225.

Hanraets, P. Intergemeentelijke pendel in Limburg (Maastricht: ETIL, 1993).

Hansen, C., Nahrstedt, B. 'Cross-border commuting: research issues, and a case study for the Danish-German border region' in: Van der Velde, M., Van Houtum, H. (red.) Borders, regions and people (London, 2000) 69-84.

Haye, R. de la, Limburgse voorouders. Handleiding voor genealogisch onderzoek in Limburg (Maastricht, 1994 (eerste druk: 1987)).

Heijden, R. van der, 'Tijden veranderen: Limburg tussen Nederland en België. De reactie in Nederlands-Limburg op het Belgisch annexionisme van 1918-1919' Maasgouw. Tijdschrift voor Limburgse geschiedenis en oudheidkunde 111 (1992) 101-167.

Held, D., McGrew, A. 'The Great Globalization Debate: An Introduction' in: Held, D., McGrew, A. (red.) The Global Transformations Reader. An Introduction to the Globalization Debate (Cambridge/Oxford/Malden, 2003 (eerste editie: 2000)), 1-50.

Hendriks, A., Blokland, J., Bulthuis, R., Van Holst, B., Offereins, C., Voskuil, R. De gevolgen van de pendel op Duitsland in het Limburgse Herstructureringsgebied. Betoograpport en Annexenrapport (Rotterdam: NEI, 1976).

Henkes, B. Heimat in Holland. Duitse dienstmeisjes 1920-1950 (Amsterdam, 1995).

Heyman, J. Life and Labor on the Border. Working People of Northeastern Sonora, Mexico, 1886-1986 (Tucson, 1991).

Hobsbawm, E. 'Introduction: Inventing traditions' in: Hobsbawm, E., Ranger, T. (red.) The invention of tradition (Cambridge, 1993 (eerste editie: 1983)) 1-14.

Hobsbawm, E. 'Mass-producing traditions: Europe 1870-1914' in: Hobsbawm, E., Ranger, T. (red.) Inventing Traditions (Cambridge, 1993 (eerste editie: 1983)) 263-307.

Hofstede, G. Culture's Consequences. Comparing Values, Behaviours, Institutions and Organizations Across Nations. (Thousand Oaks (etc.), 2001 (eerste editie: 1980)).

Hofstede, G., Twuyver, M. van, Kapp, B., Vries, H. de, Faure, M., Claus, F., Wel, J. van der Grensoverschrijdende politiesamenwerking tussen België, Duitsland en Nederland met speciale aandacht voor de Euregio Maas-Rijn (Maastricht, 1993).

Houtum, H. van, The development of cross-border economic relations (Tilburg, 1998).

Houtum, H. van, 'An Overview of European Geographical Research on Borders and Border Regions' Journal of Borderlands Studies 15 (2000) 57-83.

Houtum, H. van, 'The Geopolitics of Borders and Boundaries' Geopolitics 10 (2005) 672-679.

Houtum, H. van, Dam, F. van 'Topophilia or Topoporno? Patriotic Place Attachment in International Football Derbies' International Social Science Review 3 (2002) 231-248.

Houtum, H. van, Velde, M. van der 'The power of cross-border labour market immobility' Tijdschrift voor Sociale en Economische Geografie 95 (2004) 100-107.

Houtum, H. van, Gielis, R. 'Elastic Migration: The case of Dutch Short-Distance Transmigrants in Belgium and German Borderlands' Tijdschrift voor Sociale en Economische Geografie 97 (2006) 195-202. 
Indetzki, H-D. 'Branchenvielfalt in der Region' in: Eschweiler, O., Van Eyll, K. (red.) Wirtschaftsgeschichte der Region Aachen (Keulen, 2000) 373-376.

Italiano, P. 'Mobilité et attractivité au sein de l'Eurégio: données d'enquête' Fédéralisme et Régionalisme: Mobilité et identités dans l'Eurégio Meuse-Rhin 3 (2002-2003) 61-83.

Jansen, J. 'Wisselende banden in een grensregio' in: Leerssen, J., Jansen, J., Jacobs, L. Historische doorkijk op het MHAL-gebied, (Maastricht, 1994) 7-10.

Janssen, M. 'Borders and labour-market integration: where is the difference between interregional and crossborder mobility?' in: Van der Velde, M., Van Houtum, H. (red.) Borders, regions and people (Londen, 2000) 47-68.

Karel, E. 'De Nota Belvedere en de identificering van een grenslandschap' Studies over de sociaal-economische geschiedenis van Limburg XLVIII (2003) 149-175.

Keating, M. The New Regionalism in Western Europe (Cheltenham/Northhampton, 1998).

Keim, W., Deppe, J., Hallo Nachbar! ... Dag buururouw! : Nederlands-Duitse betrekkingen in cartoons = Deutsch-niederländische Beziehungen in der Karikatur (Den Haag, 2001 (eerste druk: 1998)).

Kleijer, H. 'Levensverhalen. Naar een sociologie van de herinnering' Sociologische Gids 29 (2002) 430-442.

Knippenberg, H. 'The incorporation of Limburg in the Dutch state' in: Knippenberg, H., Markusse, J. (red.) Nationalising and denationalising European border regions, 1800-2000. Views from geography and history (Dordrecht/Boston/London, 1999) 39-61.

Knippenberg, H. 'The Maas-Rhine Euroregion: A Laboratory for European Integration?' Geopolitics 9 (2004) 608-626.

Knippenberg, H., Pater, B. de De eenwording van Nederland. Schaalvergroting en integratie sinds 1800 (Nijmegen, 2002 (eerste editie: 1988)).

Knippenberg, H., Markusse, J. '19th and 2oth century borders and border regions in Europe: Some reflections' in: Knippenberg, H., Markusse, J. (red.) Nationalising and denationalising European border regions, 1800-2000. Views from geography and history (Dordrecht/Boston/London, 1999) 39-60.

Knotter, A. 'Paradoxen van de grens. Ongelijke ontwikkeling, grensoverschrijdende mobiliteit en de vergelijkende geschiedenis van de Euregio Maas-Rijn' in: Studies over de sociaal-economische geschiedenis van Limburg XLVI (2001) 159-174.

Knotter, A. 'Na de Kulturraumforschung. Oude en nieuwe concepten in de grensoverschrijdende regionale geschiedschrijving' Tijdschrift voor Geschiedenis 118 (2005) 227-246.

Korres, A. 'Arbeitsmigration in der Euregio Maas-Rhein im 19. und 20. Jahrhundert. Problemstellungen und Ergebnisse eines Forschungsprojektes' Interregiones 10 (2001) 15-62.

Korres, A. 'Historische interacties in de Euregio Maas-Rijn: migratiestromen in een grensgebied' in: Studies over de sociaal-economische geschiedenis van Limburg XLVII (2002) 7-26.

Kramsch, O. 'Re-Imagining the 'Scalar-Fix' of Transborder Governance: The Case of the Maas-Rhein Euregio' in: Berg, E., Van Houtum, H. (red.) Routing Borders Between Territories, Discourses and Practices (Aldershot, 2003) 211-236.

Kronenwerth, M. Die Sozialstruktur eines Grenzraums gezeigt am Beispiel des Grenzpendlerproblems im Einzugsgebiet Aachen (niet uitgegeven scriptie Universiteit München, 1969).

Lademacher, H. 'Der ungleiche Nachbar. Das Bild der Deutschen in den Niederlanden' in: Trautmann, G. (red.) Die hässlichen Deutschen? Deutschland im Spiegel der westlichen und östlichen Nachbarn (Darmstadt, 1991) 181-193.

Lambooy, J. ‘Regio's zonder grenzen: vernieuwd beleid?’ Economisch Statistische Berichten (1990) 869-870.

Lamont, M. The dignity of working men. Morality and the boundaries of race, class and immigration (New York/ Cambridge Massachusetts, 2000).

Lamont, M., Molnár, V. 'The Study of Boundaries in the Social Sciences' Annual Review of Sociology 28 (2002) 167-195.

Langeweg, S. 'Werken over de grens: Limburgers naar Duitsland 1870-1914' Studies over de sociaal-economische geschiedenis van Limburg XLVII (2002) 27-48.

Lawrence, P., Baycroft, T., Grohmann, C. 'Degrees of Foreignness' and the Construction of Identity in French Border Regions during the Interwar Period' Contemporary History 10 (2001) 51-71.

Leerssen, J. 'Over nationale identiteit' Theoretische Geschiedenis 15 (1988) 417-430.

Leerssen, J. 'Europe as a set of borders' in: Leerssen, J., Montfrans, M. van (red.) Borders and Territories (Amsterdam, 1993) 1-14.

Leerssen, J., Jansen, J., Jacobs, L. Historische doorkijk op het MAHL-gebied. Maastricht/Heerlen, Hasselt|Genk, Aken, Luik (Maastricht, 1994). 
Leijenhorst, G. van, Wonen en werken aan weerszijden van de Nederlandse grens - fiscale aspecten (Deventer/'s-Gravenhage, 1980).

Lemmens, E. Aan Vorst en Vaderland gehecht doch tevreden zijn zij niet. Limburgse politici in Den Haag 1839-1918 (Amsterdam, 2004).

Leydesdorff, S. Wij hebben als mens geleefd: het Joodse proletariaat van Amsterdam 1900-1940 (Amsterdam, 1987).

Leydesdorff, S. De mensen en de woorden. Geschiedenis op basis van verhalen (Amsterdam, 2004).

Linthout, D. Onbekende buren (Amsterdam/Antwerpen, 2004 (eerste editie: 2000)).

Lüdtke, A. 'Introduction: What is the history of everyday life and who are its practitioners?' in: Lüdtke, A. (red.) The history of everyday life. Reconstructing historical experiences and ways of life (Princeton, 1995) 3-40.

Mann, M. States, War and Capitalism. Studies in Political Sociology (Oxford, New York, 1988).

Mann, M. 'Has Globalization Ended the Rise and Rise of the Nation-state?' Review of International Political Economy 4 (1997) 472-496.

Marquart, T., Vugt, T. van Blik over de grens: lesmateriaal over geschiedenis, geografie, economie en cultuur van de Euregio Maas-Rijn (Aken, 1996) (Sectie A: ongepagineerd).

Martínez, O. Border people: life and society in the U.S.-Mexico borderlands (Tucson, 1994).

Martiniello, M., Massart, G. 'L'Eurégio Meuse-Rhin: dynamique de l'état-nation et des identités ethno-nationales dans une région frontalière Européenne.' in: Kotek, J. (red.) L'Europe et ses villes frontières (Brussel, 1996) 231-271.

Messing, F. Geschiedenis van de mijnsluiting in Limburg. Noodzaak en lotgevallen van een regionale herstructurering (Leiden, 1988).

Milward, A. The European Rescue of the Nation-State (London, New York, 2000 (tweede editie)).

Mozer, A. 'Entwicklungspolitik zu Hause. Grenzen sind Narben der Geschichte' in: Schöndube, C. Entwicklungsregionen in der EWG. Ursache und Ausmaß der wirtschaftlichen Benachteiligung (Bonn, 1973) 13-14.

Mozer, A. Euregio. Een Europese Regio (Epse, 1973).

Mrohs, E., Heukels, J.M. Die Grenze - Trennung oder Begegnung / De grens - scheiding of ontmoeting (Den Haag, 1970).

Müller, B. 'Stille Tage im Klischee. Sinn, Unsinn und Entwicklung niederländischer Deutschlandbilder' in Müller, B., Wielenga, F. (red.) Kannitverstan? Deutschlandbilder aus den Niederlanden (Münster, 1995) 15-30.

Müller, T. 'Dwangarbeid aan de grens. Regionale aspecten van de dwangarbeid in het grensgebied bij Aken in de nazi-tijd' in Studies over de sociaal-economische geschiedenis van Limburg XLVII (2002) 49-6o.

Müller, T. 'Het zogenaamde Frankenland. Nationaal-socialistische voorlopers van een grensoverschrijdende Euregionale identiteitspolitiek, 1933-1945' Studies over de sociaal-economische geschiedenis van Limburg. Jaarboek van het Sociaal Historisch Centrum voor Limburg XLVIII (2003) 52-91.

Neubourg, C. de, Haegendoren, M. van, Grensoverschrijdende pendel in de Euregio Maas-Rijn. Conclusies en beleidsaanbevelingen (Maastricht/Diepenbeek, 1995).

Newman, D. 'Borders and Bordering. Towards an Interdisciplinary Dialogue' European Journal of Social Theory 9 (2006) 171-186.

Newman, D., Paasi, A. 'Fences and neighbours in the postmodern world: boundary narratives in political geography' Progress in Human Geography 22 (1998) 186-207.

Nicol, H., Townsend-Gault, I. 'Introduction' in: Nicol, H., Townsend-Gault, I. (red.) Holding the Line. Borders in a Global World (Vancouver/Toronto, 2005) 1-12.

Nissen, P. 'De ontplooiing van het regionaal zelfbewustzijn in de beide provincies Limburg na 1839' in: Eenheid en scheiding van de beide Limburgen. Verslagbundel van het op 26 mei 1989 te Alden Biesen gehouden congres bij gelegenheid van de herdenking van 150 jaar beide Limburgen (Leeuwarden, 1989) 181-211.

O'Dowd, L. 'The Changing Significance of European Borders' Regional and Federal Studies 12 (2002) 4, 13-36.

O'Dowd, L., Wilson, T. 'Frontiers of sovereignty in the new Europe' in: O'Dowd, L., Wilson, T. (red.) Borders, Nations and States. Frontiers of Sovereignty in the New Europe (Aldershot, 1996) 1-18.

Ohmae, K. The Borderless World. Power and Strategy in the Interlinked Economy (New York, 1999 (eerste editie: 1991).

Ohmae, K. The End of the Nation State. The Rise of Regional Economies (London, 1995).

O'Keeffe, D. 'Freedom of movement for workers in Community law. Accomplishments and prospects' in: Carlier, J-Y.; Verwilghen, M. (red.) Thirty years of free movement of workers in Europe. Conference Proceedings, Brussel, 17-19 december 1998, 19-32.

Oort, F. van, Raspe, O. Ruimtelijkeconomisch beleid in de kenniseconomie (Den Haag: RPB, 2007).

Orbons, P., Spronck, L., 'Limburgers worden Nederlanders. Een moeizaam integratieproces' Publications de la société historique et archéologique dans le Limbourg 52 (1966) 31-53. 
Oudenhoven, J. van, 'Nederlanders over Duitsers: enkele empirische gegevens' in: Vis, J., Moldenhauwer, J. (red.) Nederland en Duitsland. Elkaar kennen en begrijpen (Assen, 2001) 303-312.

Paasi, A. Territories, boundaries and consciousness. The changing geographies of the Finnish-Russian border (Chichester, 1996).

Paasi, A. 'Boundaries as social practice and discourse: The Finnish-Russian border' Regional Studies 33 (1999) 669-680.

Paasi, A. 'The Changing Discourses on Political Boundaries' in: Houtum, H. van, Kramsch, O. en Zierhofer, W. (red.) B/ordering space (Aldershot, 2005) 17-32.

Paping, R., Meer, P. van der 'Herijking van het regionale beleid' Economisch-Statistische Berichten (1988) 283-286.

Passchier, N., Amersfoort, J. van ‘De sociale betekenis van de Nederlandse nationale grenzen’ KNAG Geografisch Tijdschrift 15 (1981) 119-130.

Pennings, F. Heeft het werklandbeginsel zijn langste tijd gehad? (Deventer, 2003).

Pijpers, R. Between Fear of Masses and Freedom of Movement: Migrant Flexwork in the Enlarged European Union (Nijmegen, 2007).

Pleijter, A., Renckstorf, K., Wester, F. 'Materiaalselectie en registratie; Berichten over het buurland in dagbladen in de Nederlands-Duitse grensstreek' in: Wester, F. (red.) Inhoudsanalyse: theorie en praktijk (Deventer, 2006) $45-64$.

Provinciale Planologische Dienst Limburg, Limburg in 1960 - Feiten en Cijfers (Maastricht, 1963).

Provincie Limburg, De toekomst van Limburg ligt over de grens (Maastricht, 2007).

Raad voor het Midden- en Kleinbedrijf, Rapport inzake de gevolgen van het vrije verkeer van grensarbeiders voor de regionale arbeidsmarkt (Den Haag, 1964)

Raat, F. de, 'Keizersstad wordt Duits Silicon Valley' in: NRC Handelsblad, 5-7-1994.

Renckstorf, K. 'Vormen of spiegelen de media beelden: bijvoorbeeld het beeld van Duitsland en de Duitsers?' in: Renckstorf, K.; Janssen, J. (red.) Erger dan Duitsers... Het beeld van Duitsers en Duitsland in de Nederlandse media (Nijmegen, 1989) 17-31.

Renckstorf, K., Lange, O. Niederländer über Deutsche. Eine empirische Studie zur Exploration des Bildes der Niederländer über Deutschen. (Nijmegen, 1990).

Ricq, C. Les Travailleurs Frontaliers en Europe (Parijs, 1981).

Rose, G. 'Place and identity: a sense of place' in: Massey, D., Jess, P. (red.) A place in the world? (Oxford, 1995) 88-105.

Rutten, W. 'Werken over de grens' Weet je nog, koempel?: de mijnen in Limburg 19 (2005) 443-453.

Sack, R. Human territoriality. Its theory and history (Cambridge, 1986).

Sahlins, P. Boundaries. The making of France and Spain in the Pyrenees (Berkely/Oxford, 1989).

Sahlins, P. 'State formation and national identity in the Catalan borderlands during the eighteenth and nineteenth centuries' in: Wilson, T., Donnan, H. (red.) Border identities. Nation and state at international frontiers (Cambridge, 1998) 31-61.

Sassen, S. 'The State and the New Geography of Power' in: Kalb, D., Land van der, M., Staring, R., Steenbergen, B. van en Wilterdink, N. (red.) The Ends of Globalization. Bringing Society Back In (Lanham/Boulder/New York, Oxford, 2000) 49-66.

Sauerland, D. Grenzüberschreitende raumbezogene Informationen und ihre Difizite im belgisch-niederländisch-deutschen Dreiländereck. Dargestellt am Beispeil von Tageszeitungen und Rundfunksendern (Aken, 1994).

Schack, M. 'Cross-border commuting and integration' in: Hedelund, L.; Lindstroem, B. (red.) Northern European Baltic Integration - Yearbook 2000 (NEBI) Berlin/New York, 2000) 99-114.

Schmidt, S., Salt, J., 'The development of free movement in the European Union' in: Papademetriou, D., Meyers, D. (red.) Caught in the Middle: Border Communities in an era of Globalisation (Washington DC, 2001).

Schön, D., Rein, M. Frame Reflection. Toward the Resolution of Intractable Policy Controversies (New York, 1994).

Schüssler, H., Koof, A-P. 'Bauwirtschaft - Auf dem Weg zum Dienstleistungsbewerbe’ in: Eschweiler, O., Eyll, K. van (red.) Wirtschaftsgeschichte der Region Aachen (Keulen, 2000) 310-319.

Schwell, A. 'Living in a Box. Deutsch-Polnische Interaktion in der Grenzkontrolle' Saxony Folk Culture 17 (2005) 207-230.

Scott, J. 'Euroregions, Governance, and Transborder Cooperation Within the EU' in: Velde, M. van der, Van Houtum, H. (red.) Borders, regions and people (London, 2000) 104-115.

Sicking, M. 'Die Regio Aachen - Ein Wirtschaftsraum im Umbruch' in: Meyer, R., Sicking, M. (red.) Der Wirtschaftsstandort Aachen auf dem Weg ins 21. Jahrhundert (Aken, 2000) 23-34. 
Simons, M. 'Belgische en Nederlandse grensarbeiders in en rond Zuid-Limburg' Mens en Maatschappij 25 (1950) $236-249$ en 374-391.

Smit, J. 'Sociaal-culturele problemen achter Nederlands-Duitse grensoverschrijdende arbeidsmarkten' in: Boekema, F. (red.) Grensregio's en arbeidsmarkten. Theoretische en empirische perspectieven (Assen, 2000) 109-127.

Son, A. van, 'Between tradition and coercion: Dutch workers in Germany and Belgium, 1936-1945' Jahrbuch des italienisch-deutschen historischen Instituts in Trient 28 (2002) 483-507.

Soutif, V. 'Domicile - travail: deux lieux, deux mondes? Le cas de 'l'Euregio Meuse-Rhin'.' in: Renard, J-P. (red.) Le géogaphe et les frontiers (Parijs, 1997) 115-147.

Soutif, V. L'intégration européenne et les travailleurs frontaliers de l'Europe occidentale (Parijs, 1999).

Spapens, P., Kemenade, K. van De Grens Gemarkeerd (Hapert, 1992).

Staudt, K., Spener, D. 'The view from the frontier: theoretical perspectives undisciplined' in: Spener, D., Staudt, K. (red.) The U.S.-Mexico border. Transcending divisions, contesting identities (Boulder CO (etc.), 1998) 3-33.

Steen, I. van der 'De Europese coördinatieverordeningen inzake sociale zekerheid' in: Van Hallen, P. (red.) Grensarbeid in de Euregio Maas-Rijnland en Saar-Lor-Lux (Leuven, 1990) 81-140.

Stoddard, E. 'Frontiers, borders and border segmentation: toward a conceptual clarification' Journal of Borderland Studies 6 (1991) 1-22.

Strassoldo, R. 'Boundaries in sociological theory: a reassessment' in: Strassoldo, R., Delli Zotti, G. (red.) Cooperation and conflict in border areas (Milaan, 1982) 245-271.

Strassoldo, R. 'Border Studies: The State of the Art in Europe' in: Asiwaju, A.I., Adeniyi, P.O. (red.) Borderlands in Africa. A multidisciplinary and comparative focus on Nigeria and West-Africa (Lagos, 1989) 383-395.

Strüver, A. 'Significant insignificance - Boundaries in a borderless European Union: Deconstructing the Dutch-German transnational labour market’ Journal of Borderlands Studies 17 (2002) 21-36.

Strüver, A. "We are only allowed to re-act, not to act'. Eurocrats' strategies and borderlanders' tactics in a Dutch-German border region' in: Kramsch, O., Hooper, B. (red.) Cross-border governance in the European Union (London, 2004) 25-40.

Strüver, A. 'Spheres of Transnationalism Within the European Union: On Open Doors, Thresholds and Drawbridges Along the Dutch-German Border' Journal of Ethnic and Migration studies 31 (2005) 323-343.

Swanborn, P. Methoden van sociaal-wetenschappelijk onderzoek (Meppel, 1993 (2 $2^{\mathrm{e}}$ editie)).

Taylor, P. 'The state as container: territoriality in the modern world-system' Progress in Human Geography 18 (1994) 151-162.

Thomassen, B. 'Border Studies in Europe: Symbolic and Policital Boundaries, Anthropological Perspectives' Europaea 2 (1996) 37-48.

Thomes, P. 'Ein Industrierevier im Umbruch. Wirtschaftliche und gesellschaftliche Strukturen im Bereich der Industrie- und Handelskammer Aachen seit dem Ende des Zweiten Weltkrieges' in: Indetzki, H-D., Soénius, U. (red.) Wirtschaftsgeschichte der Region Aachen vom Ende des Zweiten Weltkrieges bis zur Gegenwart (Keulen, 2000) 11-56.

Thompson, P. The voice of the past: oral history (Oxford, 2000 (eerste editie 1978)).

Tonkiss, F. 'Analysing Discourse' in: Seale, C. (red.) Researching Society and Culture (Londen, 1998) 245-26o.

Veen, R. van der, Trommel, W. 'Maatschappelijke verandering en de verzorgingsstaat', in: Trommel, W., Veen, R. van der (red.) De herverdeelde samenleving. De ontwikkeling en herziening van de Nederlandse verzorgingsstaat (Amsterdam, 1999) 291-314.

Velde, M. van der, Houtum, H. van 'De-politicizing labour market indifference and immobility in the European Union' in: Kramsch, O., Hooper, B. (red.) Cross-border governance in the European Union (London, 2004) 41-55.

Velde, M. van der 'Grensoverschrijdend zoekgedrag op de arbeidsmarkt: De Euregio Rijn-Waal' in: Boekema, F. (red.) Grensregio's en arbeidsmarkten. Theoretische en empirische perspectieven (Assen, 2000) 95-108.

Velde, M. van der, Janssen, M., Houtum, H. van 'Job mobility in the Dutch-German regional labour market. The threshold of indifference' in: Vlisteren, G. van, Wever, E. (red.) Borders and economic behaviour in Europe. A geographical approach (Assen, 2005) 77-95.

Vereniging Europese Grenslandbewoners (VEG), '25 jaar VEG’ Pendel-info, November 2004, 6-11.

Verschueren, H. 'Arbeidsrechtelijk statuut van grensarbeiders in Europees en internationaal perspectief' in: Hallen, P. van (red.) Grensarbeid in de Euregio Maas-Rijnland en Saar-Lor-Lux (Leuven, 1990) 45-66.

Verschuren, P., Memelink, R. Media-atlas van Nederland (Den Haag, 1989).

Vila, P. Crossing Borders, Reinforcing Borders. Social Categories, Metaphors and Narrative Identities on the U.S.-Mexico Frontier (Austin, 2000). 
Vliet, I. van, 'Sociale zekerheid in de klem' in: Schuyt, K., Veen, R. van der (red.) De Verdeelde Samenleving. Een inleiding in de ontwikkeling van de Nederlandse verzorgingsstaat (Houten, 1994 (eerste editie 1986)) 93-115.

Vree, F. van, 'Massapers en modernisering. De pers als spiegel en oorzaak van maatschappelijke ontwikkelingen' in: Kleijer, H., Knotter, A. (red.) Tekens en teksten. Cultuur, communicatie en maatschappelijke veranderingen vanaf de late middeleeuwen (Amsterdam, 1992) 95-108.

Vreuls, H. Grensoverschrijdende pendel in de stedelijke zone Aken-Maastricht-Luik (niet uitgegeven scriptie Universiteit Utrecht, 1980).

Vreuls, H. 'Grenzüberschreitende Pendlerwanderungen im Raum Aachen - Mijnstreek - Maastricht - Lüttich' Informationen und Materialien zur Geographie der Euregio Maas-Rhein 10 (1982) 1-12.

Vries, G. de, 'Gewaardeerde indringers' in: NRC Handelsblad 21-9-2002.

Walpot, G. De Euregio Maas-Rijn. Een grensoverschrijdend actiegebied (niet uitgegeven scriptie Universiteit Leuven, 1992).

Weerepas, M. 'Grensoverschrijdende Arbeid in de Euregio. Belasting- en sociale verzekeringsverschillen in de Euregio?’ in: Maks, J. (red.) Eén munt, één Euregio? (Maastricht, 2002) 79-101.

Wendl, T., Rösler, M.. 'Frontiers and borderlands. The rise and relevance of an anthropological research genre' in: Rösler, M., Wendl, T. (red.) Frontiers and borderlands. Anthropological perspectives (Frankfurt am Main, 1999) 1-30.

Werner, H. 'Beschäftigung von Grenzarbeitnehmern in der Bundesrepublik Deutschland' Mitteilungen aus der Arbeitsmarkt- und Berufsforschung 26 (1993) 28-35.

Wester, F. 'Inhoudsanalyse als onderzoeksontwerp' in: Wester, F. (red.) Inhoudsanalyse: theorie en praktijk (Deventer, 2006) 9-44.

Wettere-Verhasselt, Y. van, 'Aspecten van menselijke aardrijkskunde langsheen de Belgisch-Nederlandse grens' K.N.A.G. Geografisch Tijdschrift 3 (1969) 409-418.

Wielenga, F. Van vijand tot bondgenoot. Nederland en Duitsland na 1945 (Amsterdam, 1999).

Wijers, C. 'In de schaduw van het kruis. Vrouwenlevens in de Limburgse Mijnstreek' in: Vossen, H., Kruijtzer, B., Vries, Y. de (red.) Vrouwen tussen grenzen. Limburgse vrouwen in de 1 ge en 20 eeeuw (Venlo, 1990) 44-64.

Wijers, C. 'In één hand de rozenkrans, in de andere hand een glas bier.' De Limburgse identiteit onder de loep' in Studies over de sociaal-economische geschiedenis van Limburg XLV (2000) 110-133.

Wilson, T., Donnan, H. 'Nation, state and identity at international borders' in: Wilson, T., Donnan, H. (red.) Border identities. Nation and state at international frontiers (Cambridge, 1998) 1-30.

Windmuller, J., Galan, C. de, Zweeden, A. van Arbeidsverhoudingen in Nederland. (Utrecht/Antwerpen, 1983).

Winkel, H. 'Zur Arbeitsmarktsituation in den Grenzregionen Aachen, Limburg (NL) und Verviers - eine vergleichender Überblick zum Stichtage Ende September 1984' Informationen und Materialien zur Geographie der Euregio Maas-Rhein 17 (1985) 55-63.

Wolters, A., Meens, J., Neubourg, C. de Arbeid in beweging: Feiten en ontwikkelingen van de grensoverschrijdende pendel in de Euregio Maas-Rijn (Maastricht, 1995).

Yow, V. Recording oral history. A practical guide for social scientists (Thousand Oaks/London/New Delhi, 1994).

Zabusky, S. 'Boundaries at work: Discourses and practices of belonging in the European Space Agency' in: Bellier, I., Wilson, T. (red.) An anthropology of the European Union. Building, imagining and experiencing the new Europe (Oxford, New York, 2000) 179-200.

Zanden, J.L. van, 'Geleide loonpolitiek en de internationale concurrentiepositie van Nederland, 1948-1962' Maandschrift Economie 52 (1988) 464-477.

Zestos, G. European Monetary Integration: The Euro (Mason OH (etc.), 2006).

Zillinger, S. Regionalwirtschaftlicher Strukturwandel und individuelle Arbeitsplatzproblematik - untersucht am Beispiel der Region Heinsberg und der Zeche Sophia-Jacoba (Aken, 1997).

\section{INTERNET}

Janssen, M., Gijsel, P. de Do Dutch-German Euregional labour markets really exist? Observations on actual and potential mobility (paper Euregional Conference, Maastricht, 1999) http://www.fdewb.unimaas.nl/eurecom/ PDF/Gijselpaper.PDF (bezocht 24-3-2007). 
Recchi, E., Tambini, D., Baldoni, E., Williams, D., Surak, K., Favell, A. Intra-EU Migration: A Socio-demographic Overview PIONEUR Working Paper No. 3 (Florence, 2003) http://www.obets.ua.es/pioneur/documentos_ public.php (bezocht 24-3-2007).

Stichting Euregio Maas-Rijn, Europa Concreet http://www.euregio-mr.org/emr_site/pdf/Europa_konkret_1005.pdf (bezocht 2-7-2007).

http://route.anwb.nl/routeplanner/servlet/rp (bezocht 17-2-2007).

http://ec.europa.eu/employment_social/workersmobility_2006/index.cfm?id_page=1 (bezocht 28-5-2007).

http://ec.europa.eu/employment_social/workersmobility_2006/index.cfm?id_page=140 (bezocht 28-5-2007).

http://ec.europa.eu/employment_social/workersmobility_2006/index.cfm?id_page_category=FF (bezocht 28-5-2007).

http://ec.europa.eu/regional_policy/interreg3/abc/voleta_en.htm (bezocht 21-4-2008).

http://www.emr-taskforce.org/nl/news.shtml (bezocht 2-7-2007).

http://www.etil.nl/ (bezocht 25-1-2008).

http://www.euregio-mr.org (bezocht 2-7-2007).

http://www.eures.info/ecards/index.php?lang=nl (bezocht 27-4-2008).

http://europa.eu.int/scadplus/printversion/en/cha/coooo3d.htm (bezocht 19-12-2004).

http://www.limburgadverteren.nl/bereikcijfers/ (bezocht 24-12-2006).

http://www.obets.ua.es/pioneur (bezocht 28-5-2007).

http://www.persmediamonitor.nl/cgi-bin/display.cgi?path=1_2 (bezocht 28-1-2008).

http://www.regioaachen.de/ (bezocht 1-9-2007).

http://www.ser.nl/publicaties/default.asp?desc=publicaties_bulletins_0200_4 (bezocht 28-4-2007).

http://www.ser.nl/ffi/media/Files/Internet/Publicaties/Overige/2000_2010/2003/b22433_1.ashx (bezocht 153-2008).

http://statline.cbs.nl/Stat/Web/start.asp?LA=nl\&DM=SLN\&lp=Search/Search (bezocht 15-7-2003).

http://statline.cbs.nl/StatWeb/start.asp?lp=Search/Search (bezocht 10-10-2007).

\section{CORRESPONDENTIE}

Document met cijfers over de grenspendel vanuit Nederland naar de Regio Aken 1990, 1995, 2000, ontvangen via e-mail van dhr. Sandten, Landesarbeitsamt Nordrhein-Westfalen (LAA-NRW) (28-7-2003).

E-mail-correspondentie met dhr. Kuipers van het Centraal Bureau voor de Statistiek (CBS) over de definitie van grensarbeiders (27-2-2007).

\section{FotOCOLLECTIES}

Gemeentearchief Kerkrade

Beeldbank (http://beeldbank.kerkrade.nl/) (bezocht 31-8-2008)

Sociaal Historisch Centrum voor Limburg

Fotocollectie

Spaarnestad Photo

Beeldbank (http://www.spaarnestadphoto.nl/component/option,com_memorix/Itemid,6o/lang,nl/) (bezocht 31-8-2008) 


\section{Summary \\ Crossing the line \\ Commuting from South-Limburg (NL) to Germany, \\ 1958-2001}

This study examines the relation between a border and a flow of commuters crossing it against the background of the post-war European integration process. Cross-border commuting is the phenomenon of people living in one country and having a job in another, while returning home on a daily or weekly basis. It unites two key 'European' ambitions. First of all, it is related to the pursuit of the free movement of persons, which is one of the basic principles of European integration. Together with the free movement of goods, services and capital, this is one of 'the four freedoms' that were already mentioned as vital for realising an internal market in the Treaty of Rome. Cross-border labour mobility is considered to contribute to an optimal allocation of labour as a production factor and to improve the living and working conditions of individual citizens. Above that, it is seen as integration 'from below', as it involves contacts between Europeans in everyday situations. In the early 1990 s the integration process gained momentum with the Maastricht Treaty and the establishment of the Single Market. With the achievement of the internal market, border-related obstacles to the four freedoms were supposed to be removed. This led to phrases like 'Europe without borders'. The implementation of the Schengen Treaty in 1995 (and later its incorporation into the European acquis communautaire) completed the 'borderless Europe'.

Secondly, cross-border commuting, which usually takes place in the direct vicinity of borders, is linked with the current aim of encouraging cross-border interaction and integration in European border regions. The establishment of the Single Market threw another light on border regions. Whereas before they were mostly thought of as less-developed peripheries, they have come to be seen as regions full of potential and as 'laboratories of European integration', the places where 'Europe' should first take shape. In the early 1990s, the European Commission launched the so-called INTERREG-initiative offering financial support to crossborder initiatives. This elicited an explosive growth in the number of so-called Euregions, cross-border organisations in which separate regional authorities cooperate with the goals of stimulating cross-border interaction in and the development of the border region they are part of. While only a handful Euregios existed before the introduction of INTERREG, nowadays they form a network spanning all EU borders.

In the past decades, all kinds of measures have been taken to facilitate and promote European cross-border labour mobility and more specifically, commuting across borders. Most were intended to abolish borders as institutional and informational barriers. Yet, the number of cross-border commuters in Europe has remained marginal ever since the middle of the 1970s. In spite of all efforts, at the turn of the twentieth century the European labour market was predominantly characterised by immobility. The question now is if the number of crossborder commuters has always been this low and if this has been the case everywhere.

This research concerns a long-term analysis of one specific European commuting flow, 
that from Dutch South-Limburg to Germany from 1958 until 2001. Its relation to the DutchGerman border is studied from three angles: from a regional socio-economic and socio-political viewpoint, and from the perspective of the cross-border labourers. Thus, not only the quantitative development of commuting to Germany and the way it was embedded in the socio-economic context are considered, but also its meanings in the regional public sphere of (South-)Limburg ${ }^{1}$ and for the commuters themselves. This also sheds light on the significance of the border for daily life in this region. South-Limburg is considered to be the scene of numerous cross-border contacts of old. It has been a part of one of the oldest Euregios, the Euregio Meuse-Rhine (EMR), ever since its beginning in 1976 and should hence be one of the breeding grounds of European integration. ${ }^{2}$

It has to be mentioned here that in this study, work is not only considered to be an economic phenomenon. It is also a way of participating in social life and it has a symbolic meaning. Furthermore, it is important to note that borders are always janus-faced. On the one hand, they are division lines, demarcating states' territories. On the other hand, they are lines of contact between states, because no matter how closed a border is officially, there is always a certain degree of cross-border exchange and mobility, be it of information, goods, money and/or people. It is even argued that because they are division lines, borders mark off uneven (e.g. economic) developments, which can make it attractive to cross them and thus turn them into lines of connection, the so-called border paradox. The tension between their separating and connecting qualities and the way it works out is highly changeable in time. Commuters are considered to embody this tension as they constantly move back and forth between two countries. They cross the border in order to go to work and retrace their steps at the end of the day, returning to their country of residence.

Although the dynamic and ambiguous character of borders makes them fascinating research topics, they have long been in the margins of academic attention. In the constellation of intensifying globalisation and European integration and the fall of the Iron Curtain, this has changed and borders have become a core interest for many scholars. Chapter 2 describes recent academic insights regarding borders, border regions and cross-border labour, which form the starting point of this study. Drawing on the literature in the growing and increasingly interdisciplinary field of border studies, a political-material and a socio-cultural dimension of borders are distinguished. Borders are not only territorial and administrative division lines, but also have social and symbolic significance. Although both dimensions are inextricably intertwined, they do not necessarily coincide. Whereas a border may be relatively porous in its politico-material dimension, in its socio-cultural dimension it can be impermeable, and the other way around. Daily life in border regions is characterised by a combination of 'bordered' and border transcending practices, orientations and identities. Cross-border commuters are considered to be borderline cases, as they pre-eminently personify this ambivalence. Their practices are closely associated with both dimensions of borders, as cross-border commuting entails a physical border crossing and not only a close encounter with the institutional set-up of another country, but also its population. Scholars working on cross-border

1 This part of the research is based on an analysis of articles, which appeared in regional newspapers covering the whole province of Limburg. It is therefore not always possible to speak only of South-Limburg.

2 The EMR is further composed of the Aachen Region and the Belgian provinces of Liege and Limburg and the German-speaking Community. 
commuting have predominantly concentrated on measuring the number of commuters and explaining it by analysing socio-economic and institutional push- and pull-factors. Since it has proven impossible to explain the currently very low number of cross-border labourers in Europe from this perspective, attention has recently shifted to socio-cultural factors explaining the immobility of the vast majority of the European labour force. This study combines both approaches and, unlike most other studies, puts them in a long-term perspective. Furthermore, this study adds to the field of border studies by also analysing the meanings of cross-border commuting at the regional and the individual level. The appraisal of cross-border labour in the regional public sphere is linked with the (desired) relationship between the border region and the state it is part of, which also involves a certain concept of the border. The experiences of cross-border labourers elucidate the significance of the border in their practices and perceptions and the way this developed during and, when applicable, after their career in Germany.

Besides the theoretical framework, Chapter 2 discusses the methods used to study the above-mentioned issues. These consist of an analysis of aggregated statistics regarding cross-border labour to Germany and existing studies on cross-border commuting and socioeconomic developments on both sides of the border. Articles from regional newspapers were used to gain insight into the evaluation of commuting to Germany in the regional public sphere. Finally, cross-border commuters were interviewed about their personal experiences with working in Germany.

Before setting out with the empirical part of the study, Chapter 3 further introduces the case it focuses on. It starts out with a description of the way South-Limburg's position in the Netherlands has evolved by focussing on the integration of the province of Limburg in the Dutch nation-state. This was not without problems and in this process, Limburg developed a strong regional identity. Next to that, literature on cross-border labour from South-Limburg to Germany is discussed. In the late nineteenth and the early twentieth centuries, many people from Limburg worked in Germany, for instance as seasonal labourers in brickfields. Although there are some quantitative short-term studies on the post-war development of crossborder commuting to Germany, so far no real in-depth and long-term research has been done on its evolution during this period, let alone its meanings at the regional level and the individual level of the commuters themselves.

The empirical part of this dissertation consists of three chapters. Chapter 4 deals with the development of the size and composition of the commuting flow from South-Limburg to Germany between 1958 and 2001 and its relation with the Dutch-German border. Two periods are discerned in which the labour flow displayed a highly different evolution: firstly, the late 1950 s until the late 1970 s and secondly, the 1980 s until 2001. During the first period, the number of cross-border labourers fluctuated heavily and reached the rather high level of almost 17,000 commuters in 1973. This happened against a background of exceptional socio-economic divergences between the industrial labour markets on both sides of the border. The Dutch side of the border was suffering from problems among and the eventual disappearance of its main employers, twelve coal mines. At the same time, the German side of the border was experiencing economic growth, implying a huge demand for labour and high wages. Under these circumstances it was very attractive to start commuting. The quantitative divergence went hand in hand with a noticeable qualitative match. The supply of blue collar workers in South-Limburg fit excellently with the demand for labourers in the German border region. 
Most commuters were males (often former miners) working in construction or the metal industry. Yet, in spite of the favourable circumstances on the German side and difficulties on the Dutch side of the border, the majority of the South-Limburg labour force was kept from (considering) working in Germany. After 1973, a period of economic crises set in on both the Dutch and the German sides of the border and the number of commuters dropped to less than 7,000 in 1979 .

In the second period, the number of commuters showed a much more stable development, retaining a low level of about 6,000 to 8,000 workers. The number of cross-border labourers was even smaller when the high number of German migrants who moved to South-Limburg while keeping their jobs in Germany, is taken into account. Socio-economically, both sides of the border demonstrated a comparable development. They witnessed the deepening economic crisis in the 1980 os and a restructuring of the labour market. Gradually, the service sector grew, whereas the industrial sector experienced a loss of jobs. Due to the parallel labour market developments on both sides of the border, the reason to work across the border largely disappeared. Moreover, the supply of labourers on the Dutch side no longer matched with the demand on the German side of the border. In a time of both more quantitative similarities and qualitative inequalities in terms of supply of and demand for labour, cross-border commuting thus remained a rather marginal phenomenon.

In both periods, the border was of vital importance for the development of the commuting flow. As a political-material division line, the border marked differences in socio-economic policy. In the 1960 s and 1970s, these caused uneven developments, which stimulated crossborder labour. The border hence played the paradoxical role mentioned earlier: exactly because it was a division line between labour markets on the German and the Dutch side of the border, it also connected both of them. In the 1980s and 199os, the parallel quantitative development and restructuring of the labour markets on both sides of the border went together with a growing significance of border-related institutional obstacles for cross-border labour mobility, like dissimilar educational systems. Furthermore, it is argued that during the whole research period, in its socio-cultural sense, the border mainly seems to have hindered crossborder commuting. For the majority of the South-Limburg labour force, the German labour market appears to have been a blind spot when looking for work. In other words, a threshold of indifference seems to have restrained them from even considering commuting.

In Chapter 5 attention shifts to the way cross-border commuting was interpreted in the public sphere of (South-)Limburg and the ways this was related to the Dutch-German border. It is asserted that in regional press, commuting was mostly dealt with in a normative way. During the whole research period, articles kept referring to 'the commuting problem'. Even though the term suggests otherwise, it usually had several meanings at the same time and, more importantly, did not always imply criticism of commuting. Again, two periods are distinguished: the late 1950 os until the late 1970s, when commuting was disapproved of, and the late 1970 s until 2001, when it was generally accepted and later also welcomed. These roughly coincide with the periods that were discerned in the quantitative development of the commuting flow. The (dis)agreement with commuting contrasted sharply with the number of commuters. It took place on a large scale in the years that it was condemned, while there were hardly any commuters in the years when it was accepted.

In the first period, cross-border commuting was generally regarded as undesirable. 'The commuting problem' was threefold. Dutch employers' and employees' organisations, and 
Limburg authorities, politicians and journalists contended that it had negative effects on the Dutch national economy, commuters' personal lives and, most importantly, the South-Limburg labour market. Harmonisation of Dutch and German social and fiscal legislation was seen as the best way to reduce the number of commuters. So by erasing the border in its institutional sense, it was thought that it would come to function more as a barrier towards the German labour market.

In the second period, the evaluation of commuting to Germany changed to agreement. This happened in two steps, which also involved a redefinition of 'the commuting problem' in two ways. Until the 1990s, almost every article reported on problems commuters were facing due to discrepancies between Dutch and German social and fiscal laws and regulations. Interestingly, Dutch politicians and trade unions, who at first mostly denounced commuting, now stood up for the commuters. Additionally, representatives of an interest group of crossborder labourers often directed media attention to the difficult position commuters were in. Gone were the accounts in which cross-border commuting was objected to. This is considered symptomatic of an acceptance of commuting as such. It is demonstrated that in the 1990s, commuting also had a positive connotation. The idea that the low number of crossborder commuters hampered regional development now came to be added to the definition of 'the commuting problem'. In other words, cross-border commuting came to be seen as a contribution to the advance of South-Limburg. Still, harmonisation of social and tax laws and thus partly erasing the border in its institutional sense, was considered to be the best solution to 'the commuting problem'. Contrary to the previous two decades, it was now seen as the best way to eliminate the problems and thereby facilitate and stimulate commuting.

Although most newspaper reports dealt with the political-material dimension of the border, it is argued that the socio-cultural dimension was undeniably present as well. The sociocultural dimension of the border hid in the frames of reference in which commuting was interpreted, for the judgments were closely related to the conception of South-Limburg as a border region and its (preferred) relation with the Dutch state. This also implied a certain desired degree of openness of the border. In the first period, (South-)Limburg was first and foremost considered a peripheral, but integral part of the Dutch state, which should be able to develop independently from its surrounding countries. Regional interests were defined within a nationally bordered frame of reference. Cross-border labour was subject to fierce criticism as it entailed dependence on Germany. Since the late 1970s, the interdependent relation with neighbouring countries, which went hand in hand with cross-border commuting, was first accepted and later also welcomed. In the 199os, South-Limburg came to be approached as part of the Euregio Meuse-Rhine as a central European region that would profit from crossborder labour mobility. From a de-bordered frame of reference, the border was now considered to curb cross-border commuting and at the same time regional development.

The last empirical chapter of this book, Chapter 6, is based on interviews with (former) cross-border workers and elaborates on their experiences with working in Germany in relation to the border. In tracing the routes commuters followed two points are made. Firstly, unlike the development of the size and composition of the commuting flow and the way it was evaluated in the regional public sphere, commuters' experiences could not be divided into clearly defined historical periods. This does not mean that there were not any changes in time however. Secondly, it is argued that in several ways the border was of paradoxical significance in relation to commuters' experiences. 
First of all, the character of the relation between commuting to Germany and the border changed over time. In its political-material sense, the border got new meanings. It is described how, as a physical and an institutional division line, the significance of the border changed both historically as well as in the paths commuters walked. Historically speaking, the border almost disappeared as a physical division line. Over the years, border markers and border controls were gradually abolished. As an institutional line of separation however, the border gained meaning once the commuters had started working in Germany, and the significance of this also seems to have grown historically. Cross-border workers were confronted with all kinds of, mostly unforeseen, incongruities between Dutch and German laws and regulations, which created a sense of insecurity and sometimes had serious financial consequences. Even after they had ended their careers in Germany, the border as an institutional division line could still draw a line through their lives.

Next to that, it is demonstrated that in its socio-cultural dimension the Dutch-German border exhibited much more stability, both historically and in the routes the cross-border labourers followed. Before commuters started commuting, the so-called threshold of indifference often kept them from regarding work in Germany an option. Information coming from people in their informal social networks proved crucial to overcoming this mental barrier. Nevertheless, after taking the step of accepting work in Germany, a certain degree of insecurity and reservations persisted among commuters. From a bordered frame of reference, they saw Germany as different, which led to uncertainty. After a while, commuters gradually felt at home and insecurities subsided. This also meant that they came to experience a sense of alienation from the Netherlands. The functioning of the border as a barrier was thereby reversed. Commuters' intermediary position found profound expression in the simultaneous settling down in Germany and alienation from the Netherlands. They came to feel like fremdkörper, feeling at home on neither side of the border. Their in-between position also displayed itself in an ambiguous identity. Most commuters clearly had a strong regional identity. When referring to this, they often referred to commonalities between the population of Limburg and Germans, which they had noted while working in Germany. Yet, the border remained a rather clear socio-cultural division line. Although commuters usually characterised contacts with German colleagues as good, they clearly distinguished from them in the interview by using all kinds of 'Dutch' stereotypes when referring to the Germans and distancing themselves from them as Dutch. This ambivalent identity, both bordered and de-bordered, is typical for border people.

In the second place, generally speaking, the border had a rather paradoxical meaning for the commuters in several ways. Firstly, the earlier mentioned border paradox was at work, as commuters crossed the border because of the socio-economic disparities it marked. Based on commuters' experiences, two more paradoxes can be added to this. One paradox is that precisely because commuters transcended the border on the labour market, it gained meaning in their daily lives as they felt confronted with the border as a division line. This was not only related to evident national disparities, like distinct languages and laws and regulations, but also to other things, like their German colleagues' attitudes. Even though the experienced dissimilarities were not always indisputably nationally determined, from a bordered frame of reference commuters primarily attributed them to the different national context. Another paradox is that, articulating a Dutch identity and in this way reproducing the border as a symbolic division line, did not necessarily hamper social contacts with Germans. On the contrary, in a social sense the border could become a line of connection because national identity and stereo- 
types offered a common frame of reference, which opened up opportunities for contact. Nonetheless, cross-border social relations usually remained fairly limited.

In Chapter 7, the results of studying the relation between cross-border commuting from South-Limburg to Germany from the three above-mentioned points of view are discussed and compared. They are shown to coincide with and complement each other, but also to differ from one another. Cross-border commuting and borders are multidimensional, ambiguous and changeable phenomena. Studying them in a differentiated and dynamic way precludes limited or distorted images of their mutual relation. This does not only go for academic research on cross-border labour and borders, but also for the way they are dealt with in practice. Generally speaking, although current measures to reduce the significance of the border as a political-material division line by tackling institutional discrepancies and information deficits, are very useful for those already working across borders, they will not get many currently immobile border people going. A mental threshold often keeps them from taking neighbouring countries' labour markets into account when looking for a job. This also goes for the population of Dutch South-Limburg. Besides, it has been demonstrated that the disparities marked by borders do not necessarily only hinder cross-border labour mobility, but can actually also stimulate it. Therefore, policies promoting convergence in order to increase cross-border work run the risk of actually diminishing the number of cross-border commuters. Furthermore, on the regional level, the goal of stimulating labour mobility across borders has been shown to not always find a fertile breeding ground in border areas. On an individual level, expectations regarding the withering of the border once it is crossed on the labour market have to be moderated. Whereas cross-border commuters to Germany transcended the border, they also felt more strongly confronted with it, reproduced it and could change its meanings. All in all, albeit in various and changeable ways, the Dutch-German border was of great significance in relation to commuting from South-Limburg to Germany, even though slogans such as 'Europe without borders' seem to suggest otherwise. 


\section{Curriculum Vitae}

Sophie Bouwens (1976) studeerde Algemene Sociale Wetenschappen aan de Universiteit Utrecht. Vanaf 2001 tot en met 2007 was zij als promovenda verbonden aan de Faculteit der Cultuur- en Maatschappijwetenschappen van de Universiteit Maastricht. Sinds november 2007 werkt zij als docent sociale wetenschappen aan de Haagse Hogeschool. 